ASSESIO FACHINI JUNIOR

\title{
A FORMAÇÃO DO PENSAMENTO REVERSÍVEL NO ENSINO DE QUÍMICA ANALÍTICA QUALITATIVA
}




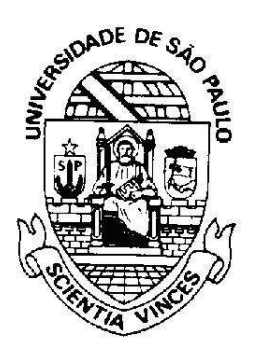

ASSESIO FACHINI JUNIOR

\section{A FORMAÇÃO DO PENSAMENTO REVERSÍVEL NO ENSINO DE QUÍMICA ANALÍTICA QUALITATIVA}

Dissertação apresentada à Faculdade de Educação da Universidade de São Paulo como exigência parcial para a obtenção do título de Mestre em Educação em Ensino de Ciências e Matemática.

Orientadora:

Dra Sonia Maria Vanzella Castellar 
AUTORIZO A REPRODUÇÃO E DIVULGAÇÃO TOTAL OU PARCIAL DESTE TRABALHO, POR QUALQUER MEIO CONVENCIONAL OU ELETRÔNICO, PARA FINS DE ESTUDO E PESQUISA, DESDE QUE CITADA A FONTE.

Catalogação na Publicação

Serviço de Biblioteca e Documentação

Faculdade de Educação da Universidade de São Paulo

$375.22 \quad$ Fachini Junior, Assesio

F139f A formação do pensamento reversível no Ensino de Química Analítica Qualitativa / Assesio Fachini Junior; orientação Sonia Maria Vanzella Castellar. São Paulo: s.n., 2009.

180 p. il.; anexo

Dissertação (Mestrado - Programa de Pós-Graduação em Educação. Área de Concentração: Ensino de Ciências e Matemática) - - Faculdade de Educação da Universidade de São Paulo.

1. Química (Estudo e ensino) 2. Conceitos (Processos cognitivos) 3. Aprendizagem 4. Experimentos científicos 5. Formação de professores I. Castellar, Sonia Maria Vanzella, orient. 


\section{FOLHA DE APROVAÇÃO}

Candidato:

Título:

Instituto:

Linha de pesquisa:

Orientadora:

Banca examinadora:
Assesio Fachini Junior

A formação do pensamento reversível no Ensino de Química Analítica Qualitativa

Universidade de São Paulo

Faculdade de Educação

Ensino de Ciências e Matemática

$D^{a}{ }^{a}$ Sonia Maria Vanzella Castellar EDM - FEUSP

$\mathrm{Dr}^{\mathrm{o}}$ Agnaldo Arroio EDM - FEUSP

$\mathrm{Dr}^{\mathrm{a}}$ Simone Jaconetti Ydi

Centro Universitário Fundação Santo André

$\operatorname{Dr}^{\mathrm{a}}$ Marineide de Oliveira Gomes UNIFESP - Campus Guarulhos

$D^{\mathrm{a}}$ Silvia Luiza Frateschi Trivelato EDM - FEUSP

Dr $^{\mathrm{a}}$ Kathia Maria Honorio $E A C H$ - USP

$D^{\mathrm{a}}$ Ermelinda Moutinho Pataca EDM - FEUSP 
Ao meu pai Assesio e a minha mãe Cida pela constante presença, pela amizade, incentivo, conselhos, pelos bons exemplos e principalmente pelo carinho que nunca me faltou. 
Agradeço à professora $\operatorname{Dr}^{\mathrm{a}}$ Sonia Castellar pela generosa paciência, pela firmeza de caráter e por acreditar no meu trabalho. Aos professores $\operatorname{Dr}^{\circ}$ Agnaldo Arroio e $\operatorname{Dr}^{\mathrm{a}}$ Sílvia Trivelato pelas críticas e sugestões no exame de qualificação. Aos professores que no exercício de sua profissão contribuíram para a minha formação, em especial ao professor Ms. Oswaldo Felippe Junior (in memorian), em quem busco inspiração para minha prática docente, e à $\operatorname{Dr}^{\mathrm{a}}$ Marineide Oliveira Gomes que em suas aulas de Didática mostrou-me a beleza da docência, esta profissão na qual me realizo e me completo. Ao meu amigo Ms. Decio Daltin por todos os ensinamentos químicos e pelas lições profissionais. À minha professora Dr $^{\mathrm{a}}$ Simone Jaconetti Ydi por ter me encantado com o Ensino de Química Analítica. À professora Roelí Nascimento Paulucci pela acolhida, pelos ensinamentos e pela grande amizade e cumplicidade que há entre nós. Ao meu incomparável amigo Denis Eduardo de Oliveira pela constante presença e companheirismo, por tudo o que dividimos e dividiremos ao longo de nossas vidas. Por fim, à professora Márcia Corrêa Silveira, mantenedora do Colégio e Faculdade Anchieta, ao professor Dr $^{\circ}$ Carlos Rivera Ferreira, à professora Sandra R. M. Henriques e ao professor Ms. Vanderlei de Oliveira Cruz por permitirem a realização desta pesquisa e por todas as oportunidades de crescimento profissional que esta Instituição me proporciona. À minha técnica de laboratório, Maria do Céu Lima, pelas constantes gentilezas e colaboração. Em especial agradeço a todos os meus alunos, pois são vocês o motivo de minha pesquisa. 
“A principal meta da educação é criar homens que sejam capazes de fazer coisas novas, não simplesmente repetir o que outras gerações já fizeram. Homens que sejam criadores, inventores, descobridores. A segunda meta da educação é formar mentes que estejam em condições de criticar, verificar e não aceitar tudo que a elas se propõe. O professor não ensina, mas arranja modos de a própria criança descobrir. Cria situações-problemas”. 


\section{RESUMO}

Título: A formação do pensamento reversível no Ensino de Química Analítica Qualitativa

Nesta pesquisa investigamos em um grupo de estudantes do curso de Química a construção do raciocínio através da argumentação dos alunos, suas estruturas cognitivas e articulações na resolução de problemas de uma atividade prática de Química Analítica Qualitativa, mais especificamente pesquisa de cátions e ânions numa marcha analítica. Após a transcrição das falas registradas em vídeo, analisamos a argumentação e o gênero do discurso dos estudantes e verificamos a importância da estruturação do pensamento reversível (ou ainda chamado de mobilidade retroativa) para a formação do Químico, bem como um raciocínio lógico-formal. Conseqüentemente, procuramos avaliar as razões pelas quais os alunos não estabelecem uma aproximação entre a teoria e a experimentação, além da deficiência na argumentação a respeito dos conceitos teóricos e os fenômenos ocorridos nesta prática de laboratório, o que demonstra pouca ou nenhuma compreensão destes conceitos. Os resultados obtidos apontam que as atividades práticas em Química Analítica Qualitativa revelam-se fundamentais para que o aluno possa apreciar a lógica envolvida na descoberta do conhecimento pela interação com o fenômeno e não meramente por uma repetição mecânica de procedimentos experimentais, como normalmente se verifica. A postura adotada pelo professor em muito contribuirá para o sucesso ou não desse objetivo, pois deve haver na sala de aula uma interação dialética e dialógica em toda a prática didática e experimental da disciplina.

Palavras-chave: Ensino de Química, conceitos científicos, aprendizagem, experimentos, formação de professores. 


\begin{abstract}
Title: The reversible thought formation process for Qualitative Analytical Chemistry

In the present research it was investigated the formation of the thought throughout the students' argumentations in a chemistry course, its cognitive structures and articulations in solving problems in a practical activity of qualitative analytical chemistry, more specifically, the study of cations and anions in an analytic march. After the video talk transcription, it was analyzed the argumentation and the sort of the speech and it was verified the importance of the reversible thought structuring (also called retroactive mobility) for a Chemist formation, as well as a formal logical reasoning. Consequently, we looked forward to evaluate the rezones why students can not link the theory and the experimentation, more over the deficiency in argumentation about the theoretical concepts and the phenomenal shown in the laboratory practice, what shows few or no comprehension of those concepts. The results reveal that it is fundamental the use of practical activities in Qualitative Analytical Chemistry. With this experience the students can appreciate the logic involved in the discovery of the knowledge through the interaction with the phenomenon and not only for a mechanical repetition of experimental procedures, as the daily routine shows. The adopted posture for the teacher will deeply contribute for the success or not of this goal, therefore, it must have in class a dialectic interaction and dialogic in all didactic practice and experimental of the subject.
\end{abstract}

Key word: Chemistry teaching, scientific concepts, learning, experiments, teacher's formation. 


\section{LISTA DE FIGURAS}

Figura 01 Representação didática das regiões do espectro eletromagnético com destaque à região visível do espectro eletromagnético.

Figura 02 Ensaio de chama realizado no bico de Bunsen com diferentes cátions metálicos que produzem um espectro luminoso característico para cada elemento.

Figura 03 Solução de alguns sais (solúveis). A maioria dos cátions de metais de transição é colorida quando em solução aquosa.

Figura 04 Reação entre $\mathrm{o}_{\mathrm{AgNO}}$ (aq) $\mathrm{e} \mathrm{NaCl}_{(\mathrm{aq})}$ onde ocorre a formação de $\mathrm{AgCl}_{(\mathrm{s})}$, um precipitado branco.

Figura 05 Exemplos de reações de precipitação de hidróxidos metálicos de ferro III, cobre II, cromo III e cobalto II.

Figura 06 Exemplos de reações de precipitação de cloreto, brometo e iodeto com nitrato de prata, sendo a cor do precipitado uma característica analítica importante.

Figura 07 Exemplos de reações de precipitação de nitrato de chumbo e iodeto de potássio, obtendo-se iodeto de chumbo (sólido) e nitrato de potássio (em solução aquosa). 


\section{SUMÁRIO}

INTRODUÇÃO

CAPÍTULO 1

$\begin{array}{ll}\text { O Ensino de Química Analítica Qualitativa } & 18\end{array}$

1.1 Breve histórico da Química Analítica 20

1.1.1 A Química Analítica no Brasil 28

1.2 A práxis experimental em Química Analítica Qualitativa 31

1.3 Como se ensina Química Analítica Qualitativa 45

CAPÍTULO 2

O pensamento reversível e a argumentação nas aulas de Química 50

Analítica Qualitativa

2.1 O pensamento reversível e as estruturas lógicas 55

2.1.1 Os estágios do desenvolvimento humano 60

2.2 Caracterização dos gêneros discursivos 69

2.2.1 As interações sociais do discurso e as intenções do professor 75

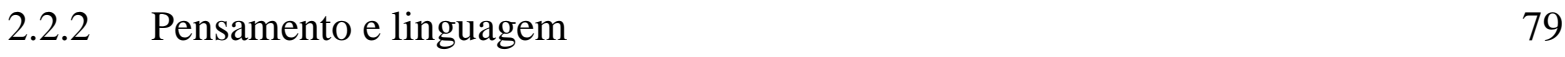

2.3 O conteúdo da argumentação em sala de aula e as abordagens $\quad 82$ comunicativas

\section{CAPÍTULO 3}

Estudo da argumentação e da estruturação do pensamento reversível por meio das atividades didáticas nas aulas de Química Analítica Qualitativa

3.1 Plano de aula da disciplina $\quad 89$

3.2 Análise da argumentação na atividade experimental 92

3.3 Análise das respostas das questões da atividade teórica 108

3.3.1 Questões propostas na avaliação e estudo das respostas 110

3.4 A articulação entre a atividade experimental e a atividade teórica 124

CONSIDERAÇÕES FINAIS 127

REFERÊNCIAS $\quad 134$

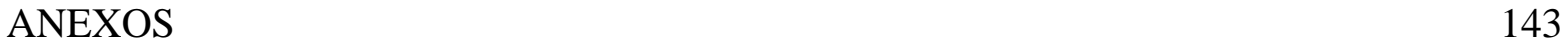




\section{INTRODUÇÃOO}

As investigações desta pesquisa surgem da interface entre as diferentes experiências vividas no setor industrial e tecnológico como Técnico em Química e Químico Pesquisador, e também das práticas docentes de Química Analítica para o Ensino Técnico Profissionalizante e Superior e Química (Geral) para o Ensino Médio. A intersecção entre essas experiências permitiu uma reflexão questionadora relacionada à formação oferecida pelas Escolas e Universidades que capacitam os estudantes para o exercício profissional nas atividades que absorvem estes profissionais.

Ao longo da atividade no magistério percebesse e identificasse diversos elementos e estratégias que, ora dificultavam o processo de ensino, ora facilitavam a formação. Destaca-se como principal resultado destas observações a conscientização do estudante na sua coresponsabilidade pela própria formação, pois, comumente, o aprendiz vê sua própria aprendizagem como um ato passivo e de responsabilidade do professor. (GUNSTONE \& NORTHFIELD, 1992). Esta idéia é bastante comum no ensino das Ciências da Natureza e suas Tecnologias, pois imbuído de conceitos e estrutura racional do senso comum, o estudante espera que o professor decifre e traduza as "verdades" científicas a respeito do objeto estudado.

Para aqueles que se dedicam ao estudo da Química, buscando num curso técnicoprofissionalizante ou em uma Universidade o conhecimento necessário para sua formação, a aprendizagem é alcançada, mesmo que por difíceis caminhos e ao custo de memorização de fórmulas, símbolos, cores que, de início, não apresentam significado algum, mas ao longo do processo podem assumir um sentido no conhecimento. (McCLELLAN, 1984). Espera-se de um profissional da Química que suas habilidades estejam além da simples memorização de fórmulas e procedimentos, que transpassem a simples atividade operacional e que, além da qualidade na realização destas tarefas, desenvolva a capacidade na compreensão do trabalho 
executado, um questionamento crítico e reflexivo e uma significativa contribuição pessoal no resultado desta atividade.

Talvez um dos maiores desafios para o Profissional da Educação esteja em levar o estudante a ver algum sentido em estudar ou conhecer sobre algo que não lhe pareça útil ou lhe cause alguma rejeição. (YDI \& LISBOA, 2003). Diversas disciplinas e conteúdos são priorizados em detrimento de outros. Tal atitude resulta da construção de uma escala de valores que espontaneamente é demonstrada pelos estudantes, porém, muitas vezes esta distinção e valorização pode ter sido inadequadamente construída, pois um determinado conhecimento não lhe foi apresentado de modo a criar sentido e aplicação nas suas atividades. (FACHINI, 2004).

O Químico muitas vezes é visto como um profissional distante das realidades sociais, alguém imerso no ambiente do laboratório, cercado por vidrarias, reagentes, instrumentos, envolto em segredos e perigos. O estudante que busca o aprendizado da Química que o leve a uma atuação profissional tem arraigado mentalmente esta imagem, e sua ansiedade em manipular as vidrarias, os reagentes, produzir fumaça, ferver líquido, modificar materiais, impedem que os discursos teóricos e formativos do professor sejam apreciados causando desmotivação, frustração e impressão de pouco aproveitamento. O educador por sua vez mantém em sua postura uma fundamentação teórica que sustenta a prática, estruturando-a pelas técnicas analíticas, síntese de compostos, características morfológicas, reatividade, cinética e termodinâmica das reações. A distância entre estas duas posturas pode dificultar o processo de ensino e aprendizagem e tornar moroso o alcance de resultados eficazes.

O estudante, ao deixar o ambiente escolar para iniciar sua vida profissional finalidade de todo o processo vivido nas Escolas e Universidades - depara-se com um ambiente e situações no qual sua ação diante da resolução de problemas deve ser adequada e as suas estratégias estruturadas em sólidos fundamentos. Todavia, muito mais do que executar 
corretamente uma análise ou operar um instrumento ele deve ser capaz de teorizar, compreender, questionar e argumentar sobre as tarefas a ele propostas e sobre os resultados obtidos. Uma formação educacional que satisfatoriamente só lhe capacite para a execução de tarefas mecânicas não atende esta necessidade. Por outro lado, um currículo fundamentado estritamente em teorias, pouco aproveitamento terá nos ambientes industriais, profissionais e de pesquisa. Faz-se necessário a justaposição destas duas maneiras de formar, para que, somadas e balizadas pelas necessidades atuais do mercado de trabalho, propiciem a formação de profissionais capacitados integralmente no exercício de sua profissão, aliadas às dimensões técnica, política, ética e estética. (RIOS, 2001).

O aprendizado não pode prescindir da teoria e da prática. Aprender significa estar apto a fazer. Para isso é necessário que se conheça os fundamentos (teoria), mas que se desenvolva as habilidades necessárias à transformação desses fundamentos em ações do dia-a-dia, através da prática, desenvolvendo aptidões. A intrigante tensão teoria versus prática parece permear a formação em diversos setores da nossa sociedade. (MELO, 2002). Esta dicotomia foi percebida nas relações profissionais na qual nos chama a atenção o discurso de diversos profissionais que demonstravam pouco ou nenhum apreço pelos fundamentos teóricos adquiridos ao longo de sua vida acadêmica. Poucos recorriam a eles para justificar suas intervenções técnicas ou propostas de ações. Não havia argumentação a respeito dos procedimentos realizados e tão pouco estes argumentos estavam associados aos fundamentos teóricos.

Nesta pesquisa investiga-se num grupo de estudantes do curso de Química a construção do raciocínio através argumentação dos alunos, suas estruturas cognitivas e articulações na resolução de problemas de uma atividade prática de Química Analítica Qualitativa, mais especificamente pesquisa de cátions e ânions, para avaliar, após uma seqüência de aulas, a utilização dos fundamentos teóricos para uma marcha analítica - uma 
práxis experimental - verificando isto por meio da argumentação e análise do discurso. A avaliação da transcrição das falas, obtida através dos registros em vídeo, foi realizada pelo referencial teórico dos fundamentos da psicologia genética de Jean Piaget na qual se verifica a importância da estruturação do pensamento reversível (ou ainda chamado de mobilidade retroativa) para a formação do Químico. Conseqüentemente, procura-se avaliar as razões pelas quais não se estabelece tal aproximação e tão pouco uma deficiência na argumentação a respeito dos conceitos teóricos e os fenômenos ocorridos nesta prática de laboratório, o que demonstra pouca ou nenhuma compreensão.

Do ponto de vista educacional e de formação do Químico, muito mais interessa os processos cognitivos, a capacidade de argumentação, a interação entre os estudantes que compõe os grupos e destes com o professor, a realização do trabalho no laboratório, a percepção visual e sensorial das reações químicas que ocorrem na prática e que remetem aos fundamentos teóricos, o que provoca uma aproximação e melhor compreensão do fenômeno, do que simplesmente a assertiva determinação qualitativa e até mesmo quantitativa do cátion e ânions que formam a amostra.

Com o avanço tecnológico da Ciência e dos métodos analíticos instrumentais, este resultado seria obtido em segundos pela simples adição da amostra num espectrômetro de massa, num espectrofotômetro de chama, absorção atômica, cromatógrafo de íons ou outros métodos analíticos bastante sofisticados, desenvolvidos ao longo da própria História da Ciência e da Química. Entretanto, estes procedimentos não levariam o estudante a argumentar sobre os fenômenos de transformação, não o levariam a compreender a Química como uma ciência que estuda a transformação da matéria e não o colocaria na condição de decidir e intervir sobre o processo, mas de simplesmente executar um método instrumental que se processa sem que seja possível visualizá-lo ou controlá-lo e o resultado desta análise torna-se uma mera informação descritiva que se imprime numa tela de computador. Todavia, este é um 
conhecimento que não pode ser ignorado e deve ser adquirido pelo estudante como uma consequiência de sua formação, pois o estudo da Química Analítica o leva a compreender a Análise Instrumental como uma consequiência histórica do avanço da Ciência e da própria Química. Como competência da própria formação ele deverá ser capaz de manuseá-los e aos instrumentos analíticos recorrer como ferramenta de trabalho.

Pretende-se demonstrar que o Ensino da Química Analítica Qualitativa transcende a capacitação apenas teórica e empírica, uma vez que também possibilita ao estudante, futuro profissional e cidadão pleno, uma postura investigadora, questionadora, bem como uma visão e raciocínio sistemático científico, próprios das Ciências da Natureza. Há ainda o interesse em discutir o papel desta disciplina - Química Analítica Qualitativa - no desenvolvimento da formação da capacidade de argumentação do estudante, bem como a interação com reações químicas realizadas em tubos de ensaio, o que provoca a necessidade de um pensamento reversivo e antecipatório, a autonomia na execução das tarefas e na escolha dos reagentes para que os resultados obtidos sejam interpretados e o leve a conclusão a respeito de qual cátion e ânion é formada a amostra analisada.

Os fundamentos teóricos desta pesquisa corroboram na análise do discurso e da argumentação dos estudantes. Para isto, os trabalhos de Stephen Toulmin $(1958 ; 2004)$ a respeito da análise da retórica e comunicação dos argumentos auxiliam na compreensão da estruturação do pensamento e tipos de argumentação; já os trabalhos de Mikhail Mikhailovich Bakhtin (1986; 1993) a respeito do discurso polifônico na construção do argumento pela palavra dialogada leva-nos a uma análise destes signos, ideológicos por excelência, como uma forma de aproximação e interação com o conhecimento. As pesquisas de Anna Maria Pessoa de Carvalho (2006) a respeito da metodologia de pesquisa para estudar os processos de ensino e aprendizagem, bem como as de Eduardo Fleury Mortimer (2002; 2007) e Edênia Maria Ribeiro do Amaral (2006) a respeito da análise das zonas de um perfil conceitual no discurso 
da sala de aula muito contribuem para a estruturação das ferramentas metodológicas desta pesquisa e auxiliam na interpretação dos resultados, juntamente com as pesquisas de Maria Candida Varone de Morais Capecchi (2004) sobre a cultura científica em atividades de experimentação, associados aos trabalhos de Rosalind Driver (1997) sobre argumentação em sala de aula e aprendizado de Ciências. O estudo da formação do pensamento reversível terá como fundamento os trabalhos da psicologia genética de Jean Piaget $(1977 ; 1975 ; 1991)$, Inhelder (1975) e outros cognitivistas que nos permitem analisar o processo de formação e estruturação do pensamento, o estudo da gênese do conceito e uma abordagem sóciointeracionista. Estes serão os fundamentos teóricos desta pesquisa que propõe uma análise do discurso e da argumentação dos estudantes para a compreensão da contribuição do Ensino de Química Analítica Qualitativa na formação do pensamento reversível como conseqüência da estruturação do raciocínio e do pensamento dos estudantes. 


\section{CAPÍTULO 1}

\section{O Ensino de Química Analítica Qualitativa}

A Química Analítica Qualitativa, ensinada nos cursos Técnicos e Universitários, é um valioso instrumento para o desenvolvimento do raciocínio do aluno, não apenas para a aprendizagem da disciplina, mas, sobretudo, por ajudar a criar um constante interesse pela razão de ser de muitos fenômenos continuamente observados. (MELLO, 1977). As aulas de Química Analítica levam o aluno a uma antecipação da realidade de um laboratório da indústria e de pesquisa e exige do professor dinamismo para fornecer os exemplos necessários para educar, preparar e orientar tecnicamente o estudante para a vida profissional despertando sempre o interesse dos alunos. (LEITE, 2008).

As pesquisas realizadas por Alvim (2005) e Abreu (2006) revelam que, a partir dos meados de 1940, a disciplina de Química Analítica Qualitativa foi desaparecendo dos currículos das instituições de ensino superior que passaram a incluir o conteúdo de suas atividades de laboratório na disciplina de Química Geral. Esta redução da carga horária e desaparecimento da disciplina ocorrem porque se julgava que o conteúdo e práticas ensinadas não havia aplicabilidade direta na indústria que já se apropriava dos métodos analíticos instrumentais. Houve então uma redução da carga horária destinada às atividades experimentais e a supressão da parte teórica específica qualitativa, especialmente equilíbrios químicos.

Assim que se iniciou a diminuição da carga horária da disciplina e sua diluição, vários artigos foram publicados sobre esse assunto (WASLEY, 1946; SWIFT, 1950; STRONG, 1957; FREISER, 1957) citando como principal motivo para a supressão da disciplina o fato de que os processos analíticos ali ensinados não tinha valor prático real. Isto porque sua aplicação nas indústrias foi reduzida devido ao desenvolvimento dos métodos instrumentais 
de análise. Alguns sugeriam o ensino de princípios básicos das técnicas instrumentais (STRONG, 1957), outros uma disciplina com ênfase nos métodos de separação e não na detecção de cátions e ânions. (FREISER, 1957).

Em 1983, o prêmio Nobel da Química, Henry Taube, afirmou o erro do desaparecimento da Análise Química Qualitativa dos currículos das universidades porque esta disciplina constituía um meio de introduzir a química descritiva e de motivar os alunos a estudarem as reações químicas que, em sua opinião, "são o coração da química". (BAUM, 1984).

Houve então um consenso em torno das idéias de Taube de que a Química Analítica Qualitativa era a melhor forma de desenvolver nos alunos os conceitos fundamentais de reações, bem como a capacidade de fazer previsões sobre sua ocorrência ou não, além de poderem interpretar, apenas pela observação de alguns fenômenos e antecipações mentais o motivo das ocorrências químicas observadas em situações práticas pelo exercício da profissão. Mas, mesmo assim, os conteúdos da disciplina passaram dos cuidados dos professores Químicos Analíticos para os professores de Química Inorgânica e Geral. (LAITINEN, 1980).

Uma outra competência e habilidade importante desenvolvida pela disciplina de Química Analítica Qualitativa são a possibilidade de desenvolver no aluno a argumentação e as relações com os diversos conceitos teóricos, possibilitando uma articulação e uma aproximação dos conteúdos, o que exige do aluno autonomia para decidir qual metodologia executar, qual reagente escolher, qual novo procedimento realizar após a interpretação do resultado adquirido. Estas características desenvolvem então as atitudes esperadas em um pesquisador, atributo formal dado ao aluno após a conclusão do curso, mas que cognitivamente talvez não se tenha pelo fato do não haver este exercício acadêmico em algumas escolas e universidades. 


\title{
1.1 Breve histórico da Química Analítica
}

\begin{abstract}
Enquanto a observação é o estudo dos fenômenos tais como se apresentam naturalmente, a experimentação é o estudo dos fenômenos em condições que foram determinadas pelo experimentador. Trata-se de uma observação provocada para fim de controle da hipótese. O observador escuta a natureza, o experimentador a interroga e a força a se desvendar. (CUVIER, G. Historie dês Sciences naturelles depuis leurs origines jusqu'a nos jours. Paris, 1844, 1845, p. 321).
\end{abstract}

No século XVII, a partir dos problemas gnosiológicos (relativos ao conhecimento), surgem duas correntes opostas: o racionalismo e o empirismo. Poderia-se dizer que o racionalismo é o sistema que consiste em limitar o homem ao âmbito da própria razão, e o empirismo é o que limita ao âmbito da experiência sensível. Isto não quer dizer que o racionalismo exclua a experiência sensível, mas esta é apenas a ocasião do conhecimento e está sujeita a enganos. Para o empirismo, ao contrário, a experiência é fundamental, o trabalho posterior da razão está a ela subordinado. (ARANHA, 1986).

Estes ideais da Filosofia da Ciência nortearão todo o trabalho científico que realizarse-á nos anos seguintes ao século XVII, levando os Filósofos da Natureza a um trabalho científico de experimentação e descobertas que se revelam à medida que se estabelecia o caráter originário do cogito como auto-evidência do sujeito pensante. Como afirma Bachelard (1938; 1996), busca-se com o espírito da nova ciência, não um saber contemplativo e desinteressado, que não tenha fim em si, mas um saber instrumental, que possibilite a dominação da natureza. Surge então o chamado ideal prometéico da ciência, sendo este ideal nascido da figura mitológica de Prometeu, que, roubando o fogo de Hefesto e entregando-o aos homens promove o advento da técnica de transformação da matéria.

Os homens, condenados desde seu nascimento, aos tormentos e aos cuidados, não tinham para nutrir-se senão frutas cruas e carnes sangrentas. (...) Tomado de piedade por sua miséria, Prometeu, para colocar os homens em situação de viver melhor, de defender-se com armas eficazes contra as feras, de cultivar com instrumentos adequados a nutriente Terra, resolveu-lhe dar-lhes o fogo e 
ensinar-lhes, com a arte de trabalhar os metais, os meios de escapar à sua deplorável e lamentável sorte. (...) Aproximando-se das forjas abrasadoras de Hefestos, roubou uma centelha do fogo que fundia os metais (...) e levou-a, como oferenda, aos homens. A humanidade desde então, conheceu com o fogo, a felicidade de viver melhor, de comer alimento menos selvagem, de aquecer-se, de receber luz. Mas, em sua alegria imoderada, ela julgou-se igual aos poderes divinos, esquecendo seus deveres para com os mesmos. Zeus, então, que não quer que os homens saiam dos justos limites, colocando seus desejos mais altos que seus destinos, resolveu castigar aquele cujo roubo havia ocasionado esta presunção sacrilégica. Transportou Prometeu para o mais alto cume do Cáucaso e mandou Hefestos pregar o Titã em um rochedo escarpado. Contra a vontade o divino ferreiro obedeceu. (...) Para cúmulo do infortúnio, todas as manhãs, uma águia de asas abertas ia pastar em seu fígado imortal, e esse monstro de garras recurvas devorava, durante o dia, tudo quanto à noite podia renascer. Esse suplício deveria durar mil anos, mas, ao fim de trinta anos, Zeus, apaziguado, perdoou o culpado, consentindo então em introduzi-lo entre os Bem-aventurados. (MEUNIER, M. A lenda dourada, São Paulo, Ibrasa, 1961, p. 80-81, Nova Mitologia Clássica).

A figura mitológica de Prometeu introduz a idéia da técnica de transformação, o que leva o homem a uma premente necessidade de aprendizado. Com o surgimento da atividade industrial, o aprendizado destas técnicas coloca o homem numa condição de produtividade para atuar profissionalmente na indústria. A melhoria destas técnicas de transformação perpassam pela atividade científica experimental que o leva a descobrir, aprimorar e desenvolver.

A atividade técnica faz com que o homem se distinga da ação animal porque passa a ser dirigido por um projeto como antecipação da ação pelo pensamento e, portanto, é deliberada, intencional. Pela técnica do trabalho é estabelecida uma relação dialética entre a teoria e a prática: o projeto orienta a ação e esta altera o projeto, que de novo altera a ação, fazendo com que haja evolução dos processos empregados, o que gera um novo processo. Além disso, para que esse distanciamento da ação seja possível, é preciso que o homem tenha uma linguagem, pela qual representa o mundo (torna presente no pensamento o que está ausente) e comunica-se com o outro.

Retoma-se então a discussão anterior a respeito da experimentação onde, por forte influência do empirismo, nas últimas décadas do século XVIII e o começo do XIX, a análise química dos compostos, minerais, orgânicos e biológicos, desenvolveu-se e ampliou-se 
consideravelmente através da experimentação. Neste período, as obras de Antonie Laurent Lavoisier (1743-1794), Traité Éleémentaire de Chimie (Tratado Elementar de Química), e as do século anterior de Isaac Newton (1642-1727), Principia (Princípio), explicitam a necessidade da experimentação como questão fundamental para a Química e a Física. (NEVES, 2008). Lavoisier demonstra que nas atividades químicas a balança é um instrumento fundamental para a realização das análises, pois permite que os cientistas realizem seus experimentos e os validem baseados no célebre princípio da conservação da massa. Os métodos que usavam a balança (métodos gravimétricos) sofreram pronunciado refinamento a partir de então, havendo a possibilidade da reprodução e repetição analítica dos experimentos e a elaboração de métodos experimentais, o que torna necessário o aprendizado das novas técnicas e metodologia de análise. O uso da balança torna-se então um novo marco para a Química moderna iniciada por Robert Boyle com a publicação de sua obra Sceptical Chymist (O Químico Cético) em 1661. (ARAGÃO, 2008).

Os aspectos analíticos quantitativos de uma análise química foram aperfeiçoados graças aos esforços de químicos e de vários pesquisadores de diferentes países da Europa. Isto demonstra um aspecto fundamental na História da Ciência e da Química de que o desenvolvimento do conhecimento não é factual ou por ação heróica de uma única figura, mas pela articulação dos saberes e comunicação dos mesmos. Na Alemanha destacou-se Martin Heinrich Klaproth (1743-1817), contemporâneo de Lavoisier, cuja preocupação principal era seguir uma metodologia analítica rigorosamente científica na determinação da proporção dos componentes nos compostos. Para isto adotou técnicas e métodos analíticos que levaram a resultados mais rigorosos que os obtidos normalmente pelos outros químicos e suscitaram a descoberta de novos elementos. Na análise percentual de compostos minerais, por exemplo, mostrou que muitas vezes o valor que deixava de ser considerado para totalizar cem poderia ser atribuído a novas substâncias. Assim, foi levado a descobrir algumas "terras": óxidos de 
zircônio, urânio, telúrio e titânio. Essas, somente muitos anos mais tarde, forneceram os respectivos elementos obtidos por outros químicos usando métodos de redução.

$\mathrm{Na}$ França, Louis Nicolas Vauquelin (1763-1829) trabalhava com compostos orgânicos e com análise de compostos inorgânicos. Embora seus métodos não fossem tão rigorosos como os de Klaproth descobriu o metal cromo e uma "terra", a glicinia ou berília, cujo metal só foi isolado muitos anos mais tarde. Na Inglaterra, William Hyde Wollaston (1766-1828), um médico versado em física e química, dedicou-se ao estudo das propriedades da platina, metal já conhecido desde 1750. Seus estudos levaram a descobrir, em 1803, o paládio e o ródio, encontrados como impurezas da platina. Um dos seus alunos, Smithson Tennant (1761-1815), que também estudava a platina, descobriu em 1804 dois novos elementos, o irídio e o ósmio, em resíduos de dissolução de platina bruta com água régia (solução de ácido clorídrico e ácido nítrico). Na Rússia, Karl Karlovitch Klaus (1796-1864), um farmacêutico e químico, muito versado no estudo de metais semelhantes à platina, descobriu em 1844 o elemento rênio.

Os métodos da análise química chamada volumétrica, relativa às soluções, seus equipamentos de laboratório e técnicas associadas, começaram lentamente a evoluir a partir de 1750. Já em 1729, C. L. Geoffroy procurava determinar a "força" de vinagres indiretamente pesando a quantidade de álcali necessária para neutralizá-los. O ponto de neutralização era determinado pela cessação do ruído da reação ou pela ausência de efervescência. Nas décadas seguintes, essa prática de neutralização foi usada para estimar a reatividade dos ácidos, como o nítrico, surgindo assim o conceito de ácido forte e ácido fraco.

Também, em muitos casos, usava-se a mudança de cor de uma substância adicionada (indicador) como o tornassol, a curcuma e outras. Esses indicadores adquirem cor diferente ao se atingir o ponto de neutralização ácido-base. Os equipamentos de vidro utilizados, cilindros graduados, pipetas, buretas graduadas volumetricamente, foram inicialmente desenvolvidos 
entre 1782 e 1806. As medidas eram grosseiras e os resultados não muito confiáveis e não havia sido desenvolvida uma maneira de aferir os resultados usando-se soluções padrões. Análises volumétricas mais precisas começaram a surgir a partir de 1824 com o trabalho de Gay-Lussac sobre titulação quantitativa de ácidos e bases. Mas, somente a partir de 1850, observou-se uma popularização destes métodos de análise.

Karl Friedrich Mohr (1806-1879), um farmacêutico muito interessado em química analítica, foi responsável por um número grande de aperfeiçoamentos dos equipamentos e métodos usados na análise gravimétrica e na volumétrica. Desenvolveu-se também o uso de substâncias padrões na alcalimetria (ácido oxálico) e o chamado sal de Mohr (sulfato ferroso amoniacal) na oxidimetria. Em 1855, publicou um livro intitulado Lehrbuch der chemischanalytischen Tritiermethode ou Tratado do Método Titrimétrico de análise química. Nele, descreveu os métodos de análise volumétrica de soluções e propôs vários melhoramentos nos procedimentos de análise. Outros métodos de análise surgiram entre os quais um chamado de iodometria, introduzido por Bunsen a partir de 1853, para a determinação quantitativa de agentes oxidantes. Estas melhorias ocorrem por conta da constante experimentação e a capacidade destes pesquisadores de raciocinar a respeito do fenômeno e das teorias conhecidas até então.

Michael Faraday, que fazia pesquisas em física e química, em 1833, passou a estudar a condução de eletricidade por soluções de sais em água e de sólidos, como o gelo, e por sais minerais fundidos. Chegou-se à conclusão que havia uma relação quantitativa entre a quantidade de uma substância decomposta e a quantidade de eletricidade que passava através da solução quando fazia sua eletrólise numa célula eletrolítica. Para medir a quantidade de eletricidade, foi desenvolvida uma célula eletrolítica especial que permitia recolher os gases que se desprendiam com a decomposição da água. Mostrou que a quantidade de eletricidade que liberava um grama de hidrogênio liberava também quantidades específicas de outras 
substâncias. Assim, para 1 grama de hidrogênio liberado, 8 gramas de oxigênio, 36 de cloro, 125 de iodo, 104 de chumbo e 58 de estanho eram liberados na eletrólise de seus respectivos compostos. Denominou tais quantidades de "equivalente eletro-químicos".

Joens Jacob Berzelius (1779-1848), considerado por muitos autores e pela sociedade científica da época como o "fundador da Química Moderna", não entendeu o significado da descoberta de Faraday e a ignorou. Esta refutação dos estudos de Faraday por Berzelius nos leva a ponderar que um novo conceito (que propõe um novo conhecimento) foi partilhado, mas não foi compreendido e por isso não apresentou significado a Berzelius. Somente cinqüenta anos mais tarde, os conceitos estruturados por Faraday revelam-se de importância fundamental na determinação de pesos atômicos. Faraday, com a colaboração de William Whewell (1794-1866), estabeleceu a terminologia usada na eletroquímica - ânions, cátions, eletrodo, cátodo, eletrólito etc. - pelo uso da corrente elétrica em seus experimentos. Destas diversidades de conceitos e saberes obtidos pela experimentação e argumentação entre os pesquisadores é que surgem os métodos instrumentais de potenciometria, eletrodos de referência, pHmetros, condutivímetros e tantos outros instrumentos analíticos. Com a atenção voltada para outros problemas de eletricidade, Faraday fez também importantes descobertas como a indução magnética e ação do magnetismo sobre a luz.

Os métodos instrumentais básicos da Química Analítica desenvolveram-se, consideravelmente, na segunda metade do século XIX, a partir de 1875, embora as técnicas físicas já fossem conhecidas anteriormente. A produção de vidros ópticos de melhor qualidade permitiu, neste século, a aplicação mais freqüiente de refratômetros, espectrômetros, polarímetros e microscópios, aos problemas de interesse químico.

O espectrômetro, particularmente, sofreu muitos aperfeiçoamentos que permitiram fazer análise de elementos difíceis de serem estudados usando o método de queima de Bunsen, ou também chamado de Ensaio de Chama. A química astronômica progrediu muito 
com o trabalho de um colega de Bunsen, Gustav Robert Kirchhoff (1824-1887), que em 1859 enunciou suas leis da espectroscopia e mostrou que um corpo incandescente emite um espectro contínuo de luz e que um corpo excitado produz um espectro com linhas brilhantes. Os gases aquecidos, quando submetidos à luz branca, absorvem as mesmas cores emitidas por seus vapores quando excitados.

Usando essas leis, Kirchoff e Bunsen descobriram vários elementos a partir de 1860. Os astrônomos com uso dos espectrômetros passaram a determinar a composição química das estrelas. Os químicos passaram a utilizá-lo com freqüência nos seus estudos e nas suas análises. Sendo então imprescindível para a formação e instrução do futuro Químico o aprendizado destas técnicas e a compreensão das descobertas e invenções instrumentais analíticas dos últimos anos, por esta razão é que toda esta produção técnica e intelectual origina-se nas universidades e nos meios acadêmicos.

A utilização da luz em análise orgânica iniciou-se com a polarimetria. Esta técnica utiliza o fenômeno de polarização da luz, descoberta por Huygens, no século XVII. Jean Baptiste Biot (1774-1862), cristalógrafo francês, em 1813, descobriu que a luz, ao atravessar uma placa de quartzo ou alguns líquidos, tem seu plano de polarização girado. Verificou-se esse fenômeno com a essência de terebentina, alguns óleos naturais, como o de limão ou uma solução alcoólica de cânfora.

A partir de 1828 foram feitos vários melhoramentos nos polarímetros. Passou-se a usar um prisma especial, invenção de William Nicol (1768-1851), para separar a luz polarizada incidente em dois feixes, e utilizou-se luz monocromática alguns anos mais tarde. $\mathrm{O}$ polarímetro tornou-se mais popular depois que se descobriu como usar luz branca introduzindo-se no caminho óptico uma cunha de quartzo compensadora.

Como os açúcares são opticamente ativos, o polarímetro passou a ser adotado na análise de alimentos, particularmente na determinação da sacarose, na indústria açucareira, a 
partir de 1860. O uso de luz polarizada se estendeu ao estudo do isomerismo óptico de compostos e complexos orgânicos, a partir de 1891.

Os avanços da Óptica levaram à melhoria dos microscópios, que, a partir de 1820 , passaram a ser usados regularmente. Um dos responsáveis por estes avanços foi Ernst Abbe (1840-1905), um físico, que em 1872 desenvolveu um condensador de luz o qual fica na parte inferior da platina do microscópio. Também foi responsável, em 1886, pelo aperfeiçoamento do refratômetro, comumente usado em química orgânica.

A análise eletroquímica que está baseada na eletrólise de soluções, a partir de 1865 , passou a ser usada como método de análise química quantitativa. Wolcott Gibbs (1822-1908), a partir de 1864, descreveu métodos de determinação eletrolítica de metais. Determinou cobre, níquel, bismuto, prata, e por via indireta, a partir dos dióxidos, o manganês e o chumbo. Este processo de análise se tornou popular e seus estudos mostraram a importância das diferenças de potencial usados na eletrodeposição. Também surgiram melhoramentos nos métodos usados, foram desenvolvidos eletrodos rotatórios e de telas metálicas, com excelentes resultados.

Muitos desses avanços foram obtidos por Alexander Classen (1843-1934), na Alemanha, que publicou um livro sobre este tipo de análise, Handbuch des chemischen Analyse durch Electrolyse. Ao final do século XIX, tinha sido desenvolvida uma variedade considerável de instrumentos e métodos e eram regularmente usados em Química Analítica. Muitos deles passaram a serem usados nas indústrias, principalmente nas de alimentos e farmacêutica. A evolução do uso foi também conseqüência da disponibilidade de excelentes instrumentos produzidos por indústrias especiais que surgiram e ainda hoje se mantém ativas.

A Alquimia medieval acabou fundando, com seus estudos sobre os metais, as bases da Química Moderna. Diversas novas substâncias foram descobertas pelos alquimistas, como o arsênio. Eles também deixaram como legados alguns procedimentos que usamos até hoje, 
como o famoso "banho-maria", devido a uma alquimista chamada Maria. Ironia do destino, o desejo dos alquimistas de transmutar os metais tornou-se realidade nos nossos dias com a fissão e fusão nuclear.

Este breve histórico da Química Analítica Qualitativa (e porque não dizer da própria História da Química) tem como propósito evidenciar que a ação da Ciência leva o homem a compreender o mundo que o rodeia. Para isto a experimentação tem um papel fundamental na elaboração das teorias e conceitos e uma vez estabelecido estes saberes eles são partilhados através das diversas formas de linguagem da ciência, tornando-se passíveis de crítica, questionamento e conseqüentemente melhorias nestes processos. Didaticamente, a aproximação dos estudantes com os fatos históricos da Química os leva a compreender que o papel do Químico é explicar e controlar os fenômenos da natureza e tratando-se das ações analíticas, somente a interação com os reagentes e produtos os torna capazes de perceber os diversos conceitos envolvidos e estruturados ao longo da própria história. A ciência moderna, em seu ensino regular, afasta-se de toda referência à erudição e dá pouco espaço à história das idéias científicas. (BACHELARD, 1938; 1996, p. 34)

\begin{abstract}
Não devemos comparar a marcha da ciência com as transformações de uma cidade, onde os edifícios envelhecidos são impiedosamente demolidos para dar lugar às novas construções, mas sim com a evolução contínua dos tipos zoológicos que se desenvolvem sem cessar e acabam por se tornar irreconhecíveis aos olhares comuns, mas onde um olho experimentado reencontra sempre os vestígios do trabalho anterior dos séculos passados. Não se deve crer, pois, que as teorias antiquadas foram estéreis e vãs. (POINCARÉ, H. O valor da ciência. Rio de Janeiro: Contraponto, 2000).
\end{abstract}

\title{
1.1.1 A Química Analítica no Brasil
}

Historicamente, o desenvolvimento da Análise Qualitativa, como disciplina nos cursos de graduação em Química, esteve relacionado à ênfase que era dada à análise de minerais e à 
determinação de suas composições pelo qual o estudante deveria aprender os conceitos científicos que se firmavam com o desenvolvimento da própria História da Química e com o progresso das pesquisas e novas descobertas. A Química Analítica no Brasil teve suas raízes nos ensinamentos da chamada escola de Rheinboldt.

Heinrich Rheinboldt (1891-1955) era docente da Universidade de Bonn e veio para o Brasil quando o nazismo foi implantado na Alemanha. Ele chegou à Faculdade de Filosofia, Ciências e Letras (da atual Universidade de São Paulo) em 1935 tendo como principais objetivos organizar a subseção de Química nos moldes da tradição universitária alemã e formar professores de Química para as escolas secundárias. Rheinboldt trouxe para o Brasil a experiência universitária alemã de ensino e pesquisa em Química. Nessa área a Alemanha estava muito à frente dos outros países europeus e dos Estados Unidos, pois sua indústria química era a mais desenvolvida do mundo. (MATHIAS, 1975).

Rheinboldt priorizava as aulas de laboratório por acreditar que a base do ensino de Química era a intuição e que o aluno, para aprender a pensar, deveria vivenciar os fenômenos muitas vezes até familiarizar-se com eles. (RHEINBOLDT, 1935). Esse pensamento justifica os amplos cursos práticos realizados pelos alunos que estudavam Química naquela época. Foi também neste contexto que momentos de discussões, denominados colóquios, foram instituídos. Os colóquios tinham como objetivo possibilitar a conexão entre os fenômenos, as leis que lhes serviam de base para as aulas experimentais. Eles eram divididos em etapas que envolviam: preparo individual, explicação, perguntas, respostas e discussão crítica. A experiência mostrou que certas disciplinas, como a Química Analítica, eram ensinadas mais eficientemente sob a forma de colóquios que sob a forma de aulas tradicionais.

Em 1951, um dos primeiros discípulos de Rheinboldt, Paschoal Senise, iniciou suas pesquisas em Química Analítica estudando as reações que se passavam no sistema azotetoiodo-tiocianato. Em 1982, ele publicou um artigo defendendo a importância da Química 
Analítica na formação do Químico, dando seguimento às idéias de Rheinboldt. (SENISE, 1982). Dentre os alunos do professor Senise cabe destacar Oswaldo Espírito Santo Godinho que, posteriormente, passou a ser docente do Instituto de Química da UNICAMP, publicando então, juntamente com outros docentes da instituição, o livro Introdução à Semimicroanálise Qualitativa, bastante utilizado no país para o ensino de Química Analítica Qualitativa, juntamente com o dos autores A. I. Vogel e V. N. Alexéiev.

O trabalho de pesquisa realizado por Alvim (2005), apresenta um mapeamento da disciplina de Química Analítica Qualitativa nas Instituições de Ensino Superior do Brasil onde foram contabilizados os cursos que oferecem esta disciplina como parte integrante de sua grade curricular ou com denominações parecidas, bem como a ementa destas disciplinas $^{(1)}$. A análise dos dados de sua pesquisa aponta que $62 \%$ dos cursos de graduação em Química no Brasil possuem a disciplina de Química Analítica Qualitativa. Quando investigada a ementa dos cursos para o conteúdo de "pesquisa qualitativa de cátions e ânions", 94\% das instituições de ensino abordam este assunto com fundamentação teórica e prática, ou na disciplina em questão ou em outra disciplina. Ainda $80 \%$ das ementas descrevem o conteúdo "análise qualitativa de cátions e ânions por métodos químicos" como totalidade do programa experimental da disciplina e apenas $20 \%$ apontam como parte do programa da disciplina.

O conteúdo programático da Química Analítica Qualitativa no Brasil, geralmente compreende a teoria do equilíbrio químico em solução aquosa e a separação e identificação de

\footnotetext{
(1) Para atender à Lei de Diretrizes e Bases da Educação Nacional (LDB) promulgada em 1996 (Lei 9394/96) e o Edital $n^{\circ}$ 04/97 da Secretaria de Educação Superior do Ministério de Educação e Cultura (MEC), que estabelecem a flexibilização curricular através da inserção de atividades que possibilitem correlações entre áreas, houve uma diminuição da carga horária formal de Química Analítica Qualitativa pela introdução de disciplinas como Química Ambiental, Tratamento de Resíduos e outras. (ZUCCO, 1999). Todavia, estas disciplinas, em suas práticas experimentais, recorrerão aos conteúdos e conceitos de Química Analítica Qualitativa para realizarem suas atividades. Isto permite apenas que o conteúdo a ser ministrado não se caracterize somente pela simples memorização de reações e reprodução de procedimentos experimentais, mas que ocorram através de estudos de casos, discussão e reflexão de situações problemas que estejam mais próximos das situações reais.
} 
espécies químicas inorgânicas em solução ou em amostras sólidas, empregando métodos clássicos. Em geral, o aluno faz um estudo das reações usadas para a identificação dos cátions de cada grupo e de alguns ânions, seguido do estudo das marchas analíticas para separação e identificação dos cátions nos grupos. Por fim é dada ao aluno a tarefa de analisar uma amostra "desconhecida" (mas conhecida para o professor) na qual ele deverá aplicar um esquema sistemático de separação e identificação das espécies iônicas presentes. A seqüência, geralmente seguida pelo aluno ao analisar a amostra compreende três etapas: testes preliminares (observação da aparência da amostra, testes de solubilidade, testes de chama, pesquisa dos íons amônio e carbonato e reações com ácido sulfúrico diluído e concentrado); pesquisa dos ânions; e por fim pesquisa dos cátions. As referências bibliográficas mais utilizadas para este curso são Vogel (1981) e Baccan (1997). (ALVIM, 2005).

\title{
1.2 A práxis experimental em Química Analítica Qualitativa
}

\begin{abstract}
Os gregos chamavam práxis à ação de levar a cabo alguma coisa; mas também designa a ação moral; significa ainda o conjunto de ações que o homem pode realizar e, neste sentido, a práxis contrapõe a teoria. No marxismo, também é conhecido como filosofia da práxis, o termo ainda ganha sentido mais preciso e não se acha identificado propriamente com a prática, mas significa a união dialética da teoria e da prática. Isto é, ao mesmo tempo em que a consciência é determinada pelo modo como os homens produzem sua existência, também a ação humana é projetada, refletida, consciente. (ARANHA, 1986, p. 430).
\end{abstract}

A análise qualitativa é a parte de Química Analítica que se preocupa com a identificação dos constituintes de uma amostra, que pode ser de natureza mineral, vegetal ou animal. O procedimento para a identificação de uma espécie química consiste em provocar, na mesma, uma variação em suas propriedades, que possa ser facilmente observada e que corresponda com a constituição da dita substância. $\mathrm{O}$ agente que promove a variação chamase reagente, pois reage quimicamente com a espécie química que se deseja reconhecer. $\mathrm{Na}$ análise por via úmida a amostra é inicialmente dissolvida. A seguir, a solução da amostra é 
submetida à ação de reagentes específicos, também em solução, para que ocorram reações que permitam a identificação de um íon ou grupo de íons presentes na amostra.

A análise por via úmida é de extrema importância no contexto da análise qualitativa e é geralmente precedida pela análise por via seca. A identificação dos componentes da amostra por via úmida é feita de acordo com a marcha analítica sistemática, que consiste na separação de grupos de cátions e ânions seguidos de isolamento de cada íon para que sejam identificados.

Pode-se trabalhar com o reagente dissolvido ou não em solução, logo existem dois tipos de ensaios: reações por via seca e reações por via úmida. As primeiras são aplicáveis a substâncias sólidas, e as últimas, a substâncias em solução. Os ensaios por via seca parecem ter perdido sua popularidade; no entanto, freqüentemente eles fornecem informações úteis num período de tempo comparativamente mais curto. (MELLO, 1977).

A análise via seca mais comum é a técnica chamada de Ensaio de Chama. Seu princípio está baseado nos fundamentos de espectroscopia de luz visível conforme o postulados dos estudos de Niels Bohr (1885-1962). Através do modelo atômico de Bohr é possível explicar os espectros atômicos, pois os elétrons quando excitados energeticamente absorvem uma quantidade definida de energia promovendo então a transição eletrônica. A transição de retorno do elétron ao nível inicial produz a liberação desta mesma quantidade de energia absorvida, mas que agora é emitida na forma de ondas eletromagnéticas, na forma de luz ultravioleta ou visível. (PERUZZO, 2006).

O modelo atômico de Bohr auxilia na interpretação do Ensaio de Chama, hoje realizado por ensaios instrumentais muito mais sofisticados como espectrômetros de absorção atômica onde a amostra é atomizada numa chama, num forno aquecido eletricamente ou num plasma. O sinal da emissão luminosa interage com um monocromador que é decodificado por 
um detector que expressa o resultado da análise num espectro de absorção atômica que apresenta resultados qualitativos e quantitativos. (HARRIS, 2001).

Didaticamente, este modelo e a análise instrumental realizada é discutido através do Ensaio de Chama que consiste em levar à zona oxidante do bico de Bunsen uma pequena fração da amostra aderida a um fio de platina. O cátion da amostra em análise tem seus elétrons excitados e passam a emitir um espectro eletromagnético, todavia, nem todos os metais emitem radiação eletromagnética no comprimento de onda visível (400 a 700 nanômetros), o que torna a análise limitada a alguns cátions, mas mesmo assim possibilita a tomada de decisões para as próximas análises a serem realizadas.

A cor observada no ensaio de chama corresponde a uma frequiência de radiação eletromagnética característica. As frequiências das cores que se observam correspondem a apenas uma pequena faixa da radiação que já foi detectada. Todas as cores conhecidas estão situadas nessa pequena faixa, conhecida como a região do visível no espectro eletromagnético. O conjunto de todas as radiações eletromagnéticas conhecidas é denominado espectro eletromagnético (figura 1). Uma forma de representar esse espectro é colocar vários tipos de radiação em ordem crescente de comprimento de onda (e, portanto, decrescente de freqüência e energia). (MORTIMER, 2002).

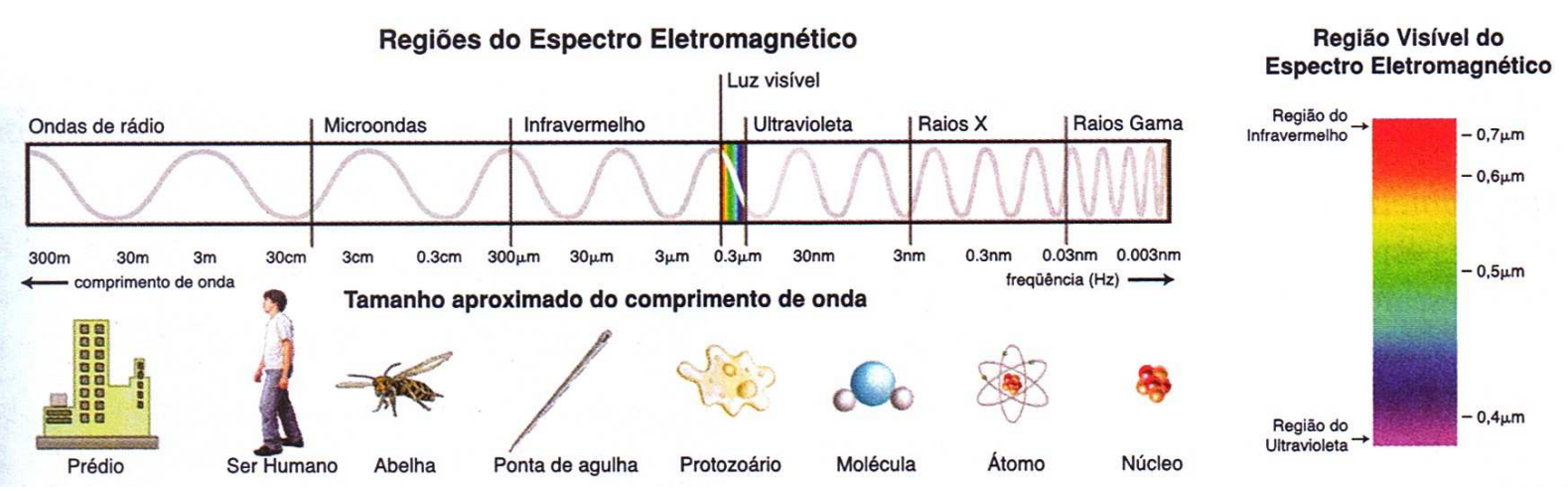

Figura 1: Representação didática das regiões do espectro eletromagnético com destaque à região visível do espectro eletromagnético. (MORTIMER, 2002, p. 105). 
A compreensão deste esquema é fundamental para que o aluno construa o conceito de comprimento de onda e desenvolva a noção de grandeza que, segundo Piaget (1975), envolve um processo operatório. É por conta desta necessidade que o esquema estabelece uma comparação entre o comprimento de onda e objetos (ponta de agulha, abelha, ser humano, prédio), levando o aluno formar uma noção de escala e que entenda as unidades de medida que são próprias desta linguagem científica (metro, centímetro, micrômetro, nanômetro). Todavia, no ensino elementar, as experiências muito marcantes, cheias de imagens, são falsos centros de interesse. É indispensável que o professor passe continuamente da mesa de experiência para a lousa, a fim de extrair o mais depressa possível o abstrato do concreto. Quando voltar à experiência, estará mais preparado para distinguir os aspectos orgânicos do fenômeno. (BACHELARD, 1938; 1996).

Compreendido então o conceito de comprimento de onda e regiões do espectro eletromagnético, experimentalmente, verifica-se então o espectro luminoso de cada cátion (figura 2), o que possibilita a utilização desta informação numa pesquisa para a determinação da espécie que forma a amostra desconhecida. Por esta razão, numa marcha analítica, os ensaios via seca precedem os ensaios via úmida, pois resultados positivos para algum elemento químico que apresenta emissão espectral visível, definirão quais reagentes deverão ser empregados numa pesquisa via úmida para confirmação do resultado encontrado. 


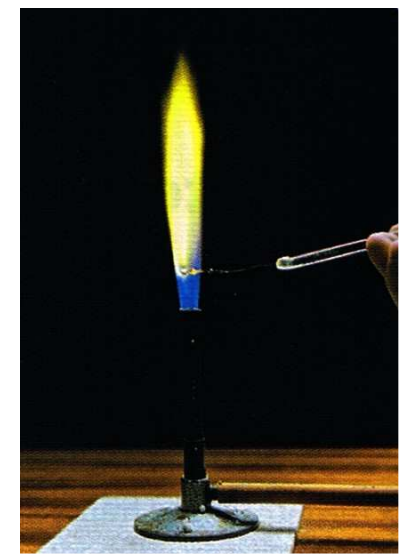

Bário

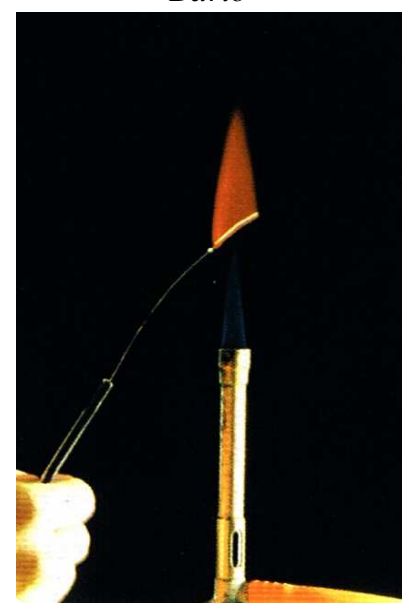

Estrôncio

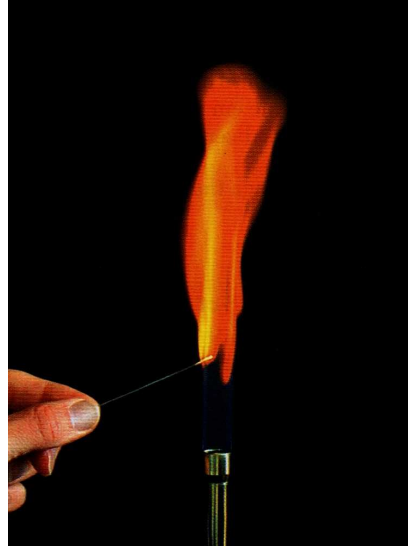

Cálcio

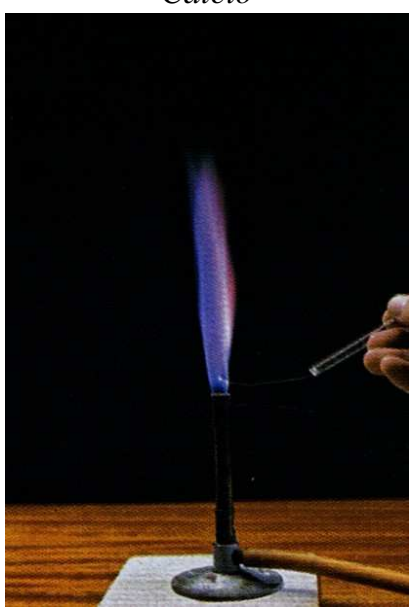

Potássio

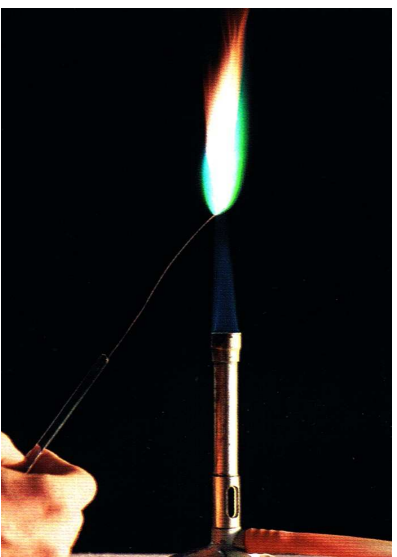

Cobre

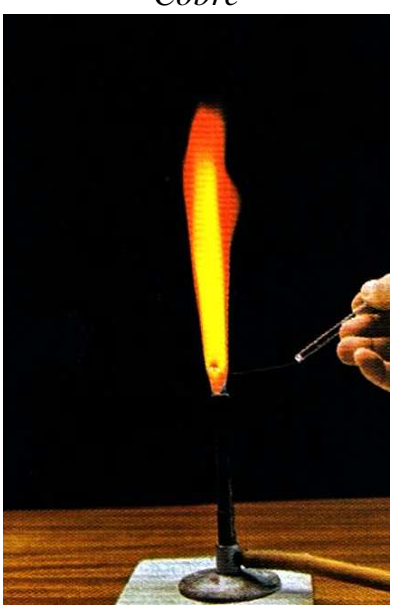

Sódio

Figura 2: Ensaio de chama realizado no bico de Bunsen com diferentes cátions metálicos que produzem um espectro luminoso característico para cada elemento. (PERUZZO, 2006, p. 148).

Vários ensaios úteis podem ser conduzidos por via seca, isto é, sem dissolver a amostra. Esses ensaios, muitas vezes, são considerados etapas preliminares para a identificação das amostras em estudo. Estes ensaios podem ser realizados em tubos fechados numa das extremidades (contendo ou não reagente) e em tubos abertos nas duas extremidades. O ensaio, utilizando o segundo tubo, é realizado quando se necessita de forte oxidação para a identificação da espécie desejada. Com aquecimento da amostra (com ou sem reagente) presente em ambos pode ocorrer uma sublimação ou o material pode fundir-se ou decomporse, acompanhado de modificação na cor, ou desprender um gás que pode levar ao seu reconhecimento em função de suas propriedades e características. 
Vogel (1981), em seu livro “Química Analítica Qualitativa”, apresenta no capítulo II (Técnicas Experimentais da análise Qualitativa Inorgânica), no item ensaios espectroscópicos, espectros de chama, além de todos os conceitos teóricos a respeito do funcionamento do equipamento, os fundamentos a respeito da emissão espectral e sua interpretação. Apresenta também uma importante tabela (tabela 1) que descreve o elemento analisado, a descrição da linha (sua cor percebida visualmente) e o comprimento de onda que somente pode ser medido instrumentalmente. Como o olho humano percebe apenas a luz visível numa faixa de 400 a $700 \mathrm{~nm}$ (nanômetro), isto muito auxilia na interpretação visual do espectro obtido no ensaio de chama.

TABELA 1: Ocorrência das linhas do espectro.

\begin{tabular}{lll}
\hline Elemento & Descrição da linha & Comprimento de onda em nm \\
\hline Sódio & Amarela, dupla & $589,0,589,6$ \\
Potássio & Vermelha, dupla & $766,5,769,9$ \\
& Violeta, dupla & $404,4,404,7$ \\
Lítio & Vermelha & 670,8 \\
& Laranja (fraca) & 610,3 \\
Tálio & Verde & 535,0 \\
Cálcio & Faixa laranja & $618,2-620,3$ \\
& Verde amarelada & 555,4 \\
& Violeta (fraca) & 422,7 \\
Estrôncio & Faixa vermelha & $674,4-662,8$ \\
& Laranja & 606,0 \\
& Azul & 460,7 \\
Bário & Faixa verde & $553,6,534,7,524,3,513,7$ \\
& Azul (fraca) & 487,4 \\
\hline
\end{tabular}

FONTE: VOGEL, A. I. Química Analítica Qualitativa. São Paulo: Mestre Jou, 1981, p. 160.

Atualmente há, entretanto, uma simplificação conceitual destes conhecimentos nas atividades dos laboratórios industriais, pois as técnicas instrumentais como um espectrômetro de absorção atômica ou de emissão de plasma é capaz de analisar uma amostra e emitir o 
resultado apenas pela análise numérica do comprimento de onda e cabe ao químico preparar a amostra, introduzi-la no equipamento e aguardar o resultado qualitativo e quantitativo. Porém, do ponto de visto de ensino e aprendizagem, questiona-se o entendimento conceitual desta prática e a capacidade deste profissional de argumentar sobre os fundamentos teóricos que sustentam esta metodologia.

A realização dos ensaios via seca, principalmente o Ensaio de Chama, é uma oportunidade de ensino profícua para a discussão e aprofundamento dos conceitos teóricos referentes à evolução do modelo atômico e dos postulados de Bohr que fundamentam as teorias modernas e proporcionam o desenvolvimento da física quântica, da dualidade ondapartícula e da análise instrumental. Há então uma ocasião didática para evidenciar que o ensino destes conceitos e teorias não é apenas uma relação matemática simples - idealizadas nas equações de Schorödinger, Broglie, na constante de Plank, nos princípios da incerteza de Heisenberg - e sim uma possibilidade de interagir com o fenômeno em laboratório e compreender, pela observação e argumentação, os desdobramentos históricos destes estudos.

As práticas de Química Analítica Qualitativa exigem uma capacidade mental classificatória e estruturada num pensamento lógico-formal para que sejam estabelecidas as devidas correlações entre os métodos e procedimentos. A análise funcional e sistemática de uma solução deve ser iniciada pelos ensaios preliminares, seguidas de ensaios para ânions e separação e identificação dos cátions presentes. Essa identificação é feita com a adição de reagentes específicos (ácido clorídrico, gás sulfídrico, amônia, sulfeto de amônio ou carbonato de amônio) que promoverá ou não a formação de precipitados e se houverem serão analisados. Os grupos de cátions são classificados de acordo com a adição desses reagentes específicos. A classificação dos ânions, adotada por Arthur Vogel (1981), envolve a identificação por produtos voláteis obtidos por tratamento com ácidos e os que dependem de reações em solução. 
O material em análise deve ser caracterizado visualmente, pois sua estrutura cristalográfica e coloração indicam que tipo de cátion pode formar a amostra. Normalmente os metais alcalinos e alcalinos terrosos são brancos, já os metais de transição apresentam cores bastante definidas. Quando dissolvidos em água para a formação da solução a ser analisada, esta apresentará coloração bastante característica (figura 3), o que torna possível a seleção dos possíveis cátions que formam a amostra separando-os em dois grupos: alcalinos (e terrosos) e de transição.

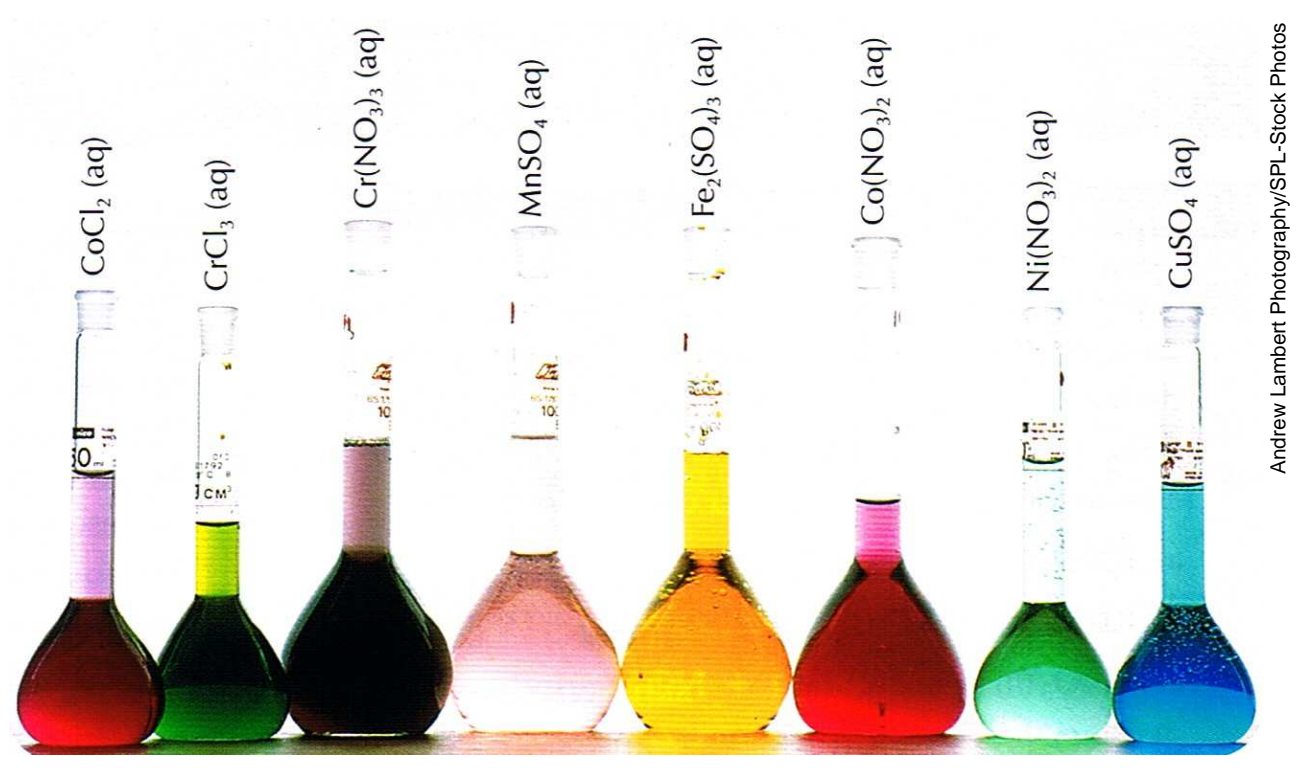

Figura 3: Solução de alguns sais (solúveis). A maioria dos cátions de metais de transição é colorida quando em solução aquosa. (PERUZZO, 2006, p. 401).

A partir da amostra em solução, iniciam-se os procedimentos da marcha analítica chamados de via úmida que consiste na produção de reações química de simples troca ou de dupla troca para que o produto da reação seja interpretado macroscopicamente, ou seja, observa-se a formação de precipitados, desprendimento de gás, mudança de coloração e até mesmo mudança de temperatura do sistema. Este conjunto de fenômenos físicos e químicos compõe os resultados que devem ser interpretados para que haja uma conclusão sobre qual cátion e ânion compõe a amostra analisada. 
Normalmente, a formação de precipitados é a evidência macroscópica mais investigada e observada numa marcha analítica, visto que uma substância em análise pode reagir com outra formando um produto insolúvel em função da constante do produto de solubilidade $\left(\mathrm{K}_{\mathrm{ps}}\right)$. Por esta razão, o estudo conceitual dos Equilíbrios Químicos faz-se tão necessário como conhecimento elementar para a realização dos procedimentos experimentais de Química Analítica Qualitativa.

O conceito de equilíbrio químico tem sido apontado por muitos autores, e também por muitos professores como problemático para o ensino e a aprendizagem. Esse conceito tem uma grande riqueza e potencial para o Ensino de Química, pois articula outros temas como reação química, reversibilidade das reações, cinética etc. (MORTIMER, 2003).

A tabela 2 apresenta alguns valores das constantes dos produtos de solubilidade $\left(\mathrm{K}_{\mathrm{ps}}\right)$ para algumas substâncias:

TABELA 2: Constantes do produto de solubilidade a $25^{\circ} \mathrm{C}$.

\begin{tabular}{lllll}
\hline Brometos & $\mathrm{AgBr}$ & $3,3 \cdot 10^{-13}$ & $\mathrm{PbBr}_{2}$ & $6,3 \cdot 10^{-6}$ \\
\hline Carbonatos & $\mathrm{BaCO}_{3}$ & $8,1 \cdot 10^{-9}$ & $\mathrm{MgCO}_{3}$ & $4,0 \cdot 10^{-5}$ \\
& $\mathrm{CaCO}_{3}$ & $3,8 \cdot 10^{-9}$ & $\mathrm{SrCO}_{3}$ & $9,4 \cdot 10^{-10}$ \\
\hline Cloretos & $\mathrm{AgCl}$ & $1,8 \cdot 10^{-10}$ & $\mathrm{PbCl}_{2}$ & $1,7 \cdot 10^{-5}$ \\
\hline Hidróxidos & $\mathrm{Al}(\mathrm{OH})_{3}$ & $1,9 \cdot 10^{-33}$ & $\mathrm{Fe}(\mathrm{OH})_{3}$ & $6,3 \cdot 10^{-38}$ \\
& $\mathrm{Fe}(\mathrm{OH})_{2}$ & $7,9 \cdot 10^{-15}$ & $\mathrm{Mg}(\mathrm{OH})_{2}$ & $1,5 \cdot 10^{-11}$ \\
\hline Iodetos & $\mathrm{AgI}$ & $1,5 \cdot 10^{-16}$ & $\mathrm{PbI}_{2}$ & $8,7 \cdot 10^{-9}$ \\
\hline Fosfatos & $\mathrm{Ag}_{3} \mathrm{PO}_{4}$ & $1,3 \cdot 10^{-20}$ & & \\
& $\mathrm{Ca}\left(\mathrm{PO}_{4}\right)_{2}$ & $1,0 \cdot 10^{-28}$ & & $1,8 \cdot 10^{-8}$ \\
\hline Sulfatos & $\mathrm{BaSO}_{4}$ & $1,1 \cdot 10^{-10}$ & $\mathrm{PbSO}_{4}$ & \\
\hline Sulfetos & $\mathrm{CaSO}_{4}$ & $2,4 \cdot 10^{-5}$ & & $3,0 \cdot 10^{-53}$ \\
& $\mathrm{Ag}_{2} \mathrm{~S}^{2}$ & $1,0 \cdot 10^{-49}$ & $\mathrm{HgS}$ & $8,4 \cdot 10^{-28}$ \\
\hline
\end{tabular}

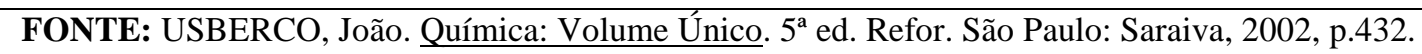


Sendo o produto de solubilidade definido pela equação genérica:

$\mathrm{a} \mathrm{AB} \rightarrow \mathrm{a}^{+}+\mathrm{b} \mathrm{B}^{-}$, o $\mathrm{K}_{\mathrm{ps}}$ pode ser então definido pela equação,

$\mathrm{K}_{\mathrm{ps}}=\left[\mathrm{A}^{+}\right]^{\mathrm{a}}\left[\mathrm{B}^{-}\right]^{\mathrm{b}}$

A interpretação deste valor numérico permite então justificar o fenômeno ocorrido e propor a escolha de um reagente que cause a precipitação de um determinado cátion ou ânion comprovando sua existência na amostra ou separando-o de outros numa investigação mais elaborada. Além disto, a cor do precipitado torna-se muito importante na identificação do analito, sendo a cor uma consequiência dos níveis de energia dos orbitais e dos campos ligantes dos spins alto e baixo. (ATKINS, 2001).

Uma reação que demonstra o conceito do produto de solubilidade e a conseqüência da interação (reação) entre as espécies químicas é representada na figura 4 entre o íon $\mathrm{Ag}^{+}$e o ânion $\mathrm{Cl}^{-}$. Como os nitratos são todos solúveis (SILVA, 2004), o íon $\mathrm{Ag}^{+}$encontra-se em solução aquosa, da mesma forma que o $\mathrm{NaCl}$, pois este também é solúvel. Isto confere a ambas soluções a característica de soluções verdadeiras. Ao misturar-se as duas soluções ocorre à formação de um produto insolúvel e branco, o cloreto de prata $(\mathrm{AgCl})$, que precipita na solução, fenômeno que justifica o valor do $\mathrm{K}_{\mathrm{ps}}$ descrito na tabela 2 , de $1,8 \cdot 10^{-10}$ para $\mathrm{o}$ cloreto de prata $(\mathrm{AgCl})$. 


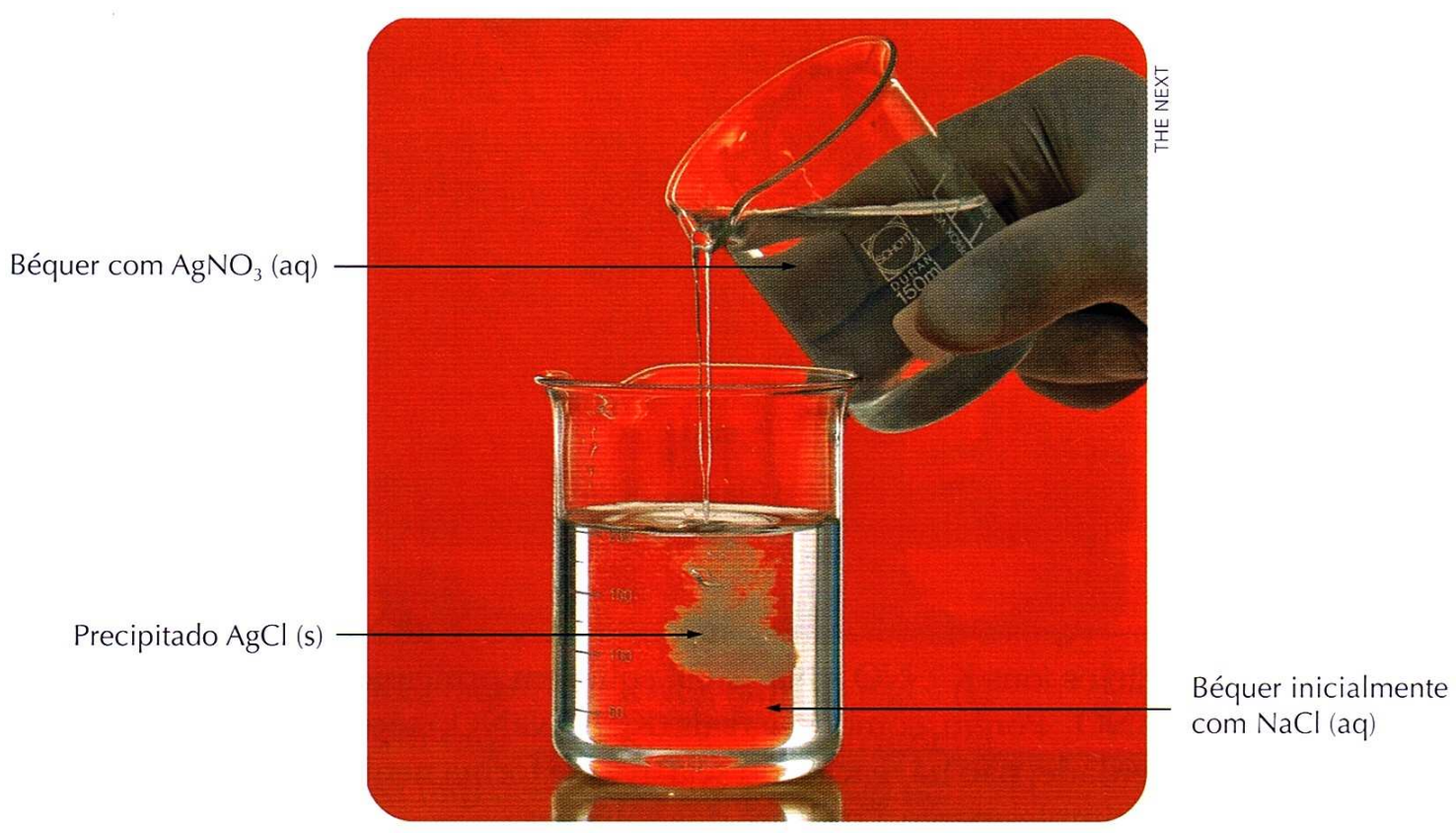

Figura 4: Reação entre o $\mathrm{AgNO}_{3(a q)}$ e $\mathrm{NaCl}_{(a q)}$ onde ocorre a formação de $\mathrm{AgCl}_{(s)}$, um precipitado branco. (PERUZZO, 2006, p. 463).

A realização deste procedimento experimental é fundamental para que o estudante forme a compreensão conceitual do valor do $\mathrm{K}_{\mathrm{ps}}$, relacionando-o com o fenômeno ocorrido, ou seja, como o valor numérico é muito pequeno, isto indica que a substância está pouco dissociada, então o equilíbrio do sistema será deslocado para a formação do precipitado (produto insolúvel), restando então uma concentração muito pequena de $\mathrm{Ag}^{+}$e $\mathrm{Cl}^{-}$em solução. O entendimento destes conceitos permite ao aluno escolher adequadamente um determinado reagente que promova então maior ou menor precipitação da espécie química de interesse. Se não há esta compreensão a escolha de cloreto, brometo ou iodeto na marcha analítica não tem significado em relação à grandeza do valor do $\mathrm{K}_{\mathrm{ps}}$, revelando novamente que não há uma estrutura lógico-formal do raciocínio e tão pouco maturação das estruturas operatórias do pensamento.

O produto de solubilidade é de grande importância na análise qualitativa, visto que, com seu auxílio, é possível não só explicar como também antecipar e prever reações de precipitação. O produto de solubilidade é, na realidade, um valor derradeiro que é alcançado 
pelo produto iônico, quando se estabelece o equilíbrio entre a fase sólida do sal ligeiramente solúvel e a solução. Se as condições se apresentam de tal forma que o produto iônico é diferente do produto de solubilidade, o sistema tenderá a ajustar-se de tal modo que o produto iônico atinja o valor do produto de solubilidade. Assim, se arbitrariamente torna-se o produto iônico maior que o produto de solubilidade, seja, por exemplo, pela adição de um outro sal com um íon comum, o sistema reajustará pela precipitação do sal sólido. Reciprocamente, se tornamos o produto iônico menor que o produto de solubilidade, como por exemplo, diminuindo a concentração de um dos íons, o equilíbrio do sistema será restabelecido pela passagem de algum sal sólido para a solução. (VOGEL, 1981).

Vários íons metálicos precipitam e se dissolvem na presença de hidróxidos. Os precipitados somente se formarão se as concentrações dos íons metálicos e hidroxila forem momentaneamente superiores àquelas permitidas pelo produto de solubilidade. Visto que, em soluções aquosas, o produto das concentrações de íons hidrogênio e íons hidroxila é rigorosamente constante $\left(\mathrm{K}_{\mathrm{w}}=1,0 \cdot 10^{-14}\right.$ a $\left.25^{\circ} \mathrm{C}\right)$, a formação de um precipitado de hidróxido metálico depende principalmente do pH da solução.

A figura 5 ilustra a precipitação de hidróxidos metálicos pela adição de hidróxido de sódio na solução. O tubo de ensaio $\mathrm{A}$ contém $\mathrm{Fe}^{3+}$; o tubo de ensaio $\mathrm{B}$ contém $\mathrm{Cu}^{2+}$; o tubo de ensaio $\mathrm{C}$ contém $\mathrm{Cr}^{3+}$; e o tubo de ensaio $\mathrm{D}$ contém $\mathrm{Co}^{2+}$. As soluções inicialmente já apresentam colorações características (o que auxilia na identificação) e, ao adicionar uma base forte, como $\mathrm{NaOH}$, ocorre a formação do precipitado pelo deslocamento do equilíbrio químico. 


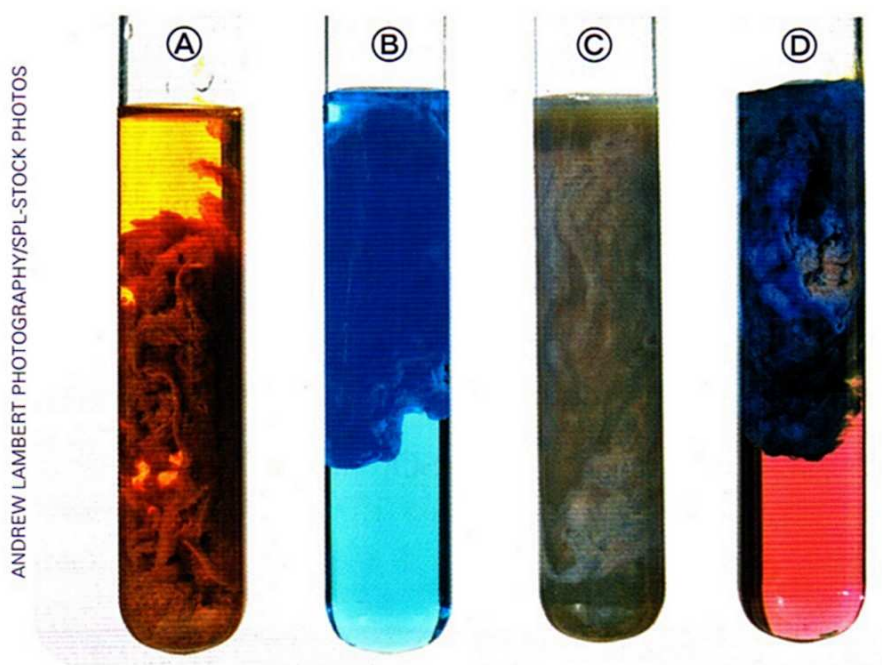

Figura 5: Exemplos de reações de precipitação de hidróxidos metálicos de ferro III, cobre II, cromo III e cobalto II . (PERUZZO, 2006, p. 465).

Quando há a necessidade de determinar-se a presença dos halogênios como cloreto, brometo ou iodeto, a reação destes ânions com o cátion $\mathrm{Ag}^{+}$forma precipitados que podem ser diferenciados pela coloração (figura 6), sendo o $\mathrm{AgCl}$ branco (E), o $\mathrm{AgBr}$ levemente amarelado (F) e o AgI mais amarelado (G).

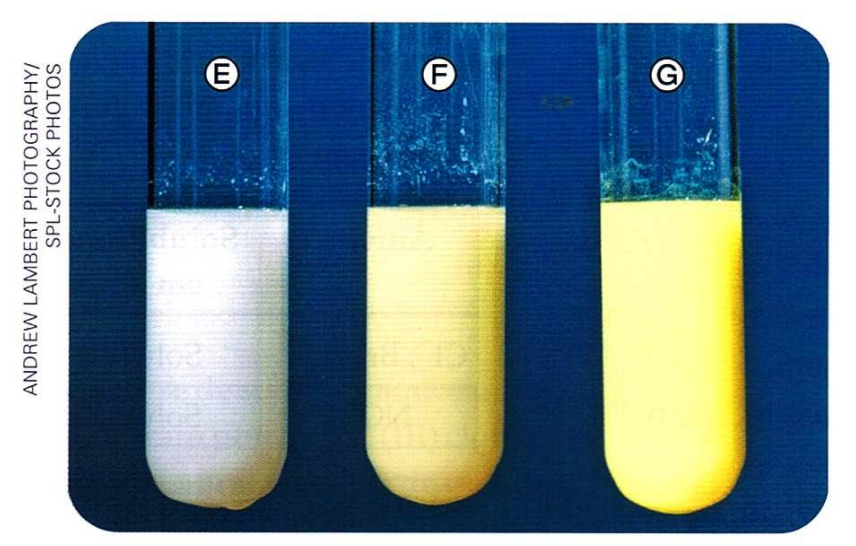

Figura 6: Exemplos de reações de precipitação de cloreto, brometo e iodeto com nitrato de prata, sendo a cor do precipitado uma característica analítica importante. (PERUZZO, 2006, p. 465).

A análise qualitativa pode ser conduzida em várias escalas. Em macroanálise, a quantidade de substâncias empregada é de 0,5 a 1 g e o volume de solução tomado para análise é cerca de $20 \mathrm{~mL}$. Na chamada semimicroanálise, a quantidade usada para análise é 
reduzida por fator de 0,1 a $0,05 \mathrm{~g}$ e o volume de solução para cerca de $1 \mathrm{~mL}$. Para microanálise o fator é da ordem de 0,01 ou menos.

Não há uma linha nítida de demarcação entre semimicro e microanálise. A primeira é chamada análise por centigramas, e a última, análise por miligrama, mas estes termos, apenas, indicam as quantidades usadas em análise. Para uma análise de rotina, a escolha se situa entre semimicro e macroanálise. A maioria das reações por via seca pode ser usada com pequenas modificações para a semimicroanálise.

Esses métodos foram introduzidos em 1840 por Frezenius que publicou um livro com um esquema de separação sistemática que se tornou a base dos esquemas atuais de separação utilizados nos cursos de Química Analítica. Em 1878, Bunsen publicou um trabalho sobre a análise qualitativa de ânions. Entre 1910 e 1920 Benedetti Pichler e Feigl pesquisaram reações mais sensíveis e mais específicas.

Os conhecimentos aqui chamados de práxis da Química Analítica Qualitativa perfazem um conjunto de saberes importantes para a formação do Químico e que devem ser compreendidos pelos alunos para que sejam capazes de, ao observarem um fenômeno de transformação da matéria, possam conceituá-los, teorizá-los e argumentar sobre eles a partir de suas experiências cognitivas. A aquisição destas competências e habilidades do raciocínio e sua estruturação ocorrem formalmente ao longo das práticas propostas pela disciplina como produto de uma prática didática curricular que tem como objetivo desenvolver a capacidade de argumentação e a formação do pensamento reversível e antecipatório no Ensino de Química Analítica Qualitativa, preocupação mais salutar do que o simples aprendizado das práticas experimentais, memorização dos procedimentos e características das reações químicas. 


\subsection{Como se ensina Química Analítica Qualitativa}

A disciplina de Química Analítica Qualitativa é normalmente oferecida nos cursos técnicos profissionalizantes, bem como nos cursos superiores de Bacharelado e Licenciatura em Química. Anteriormente ou concomitantemente o aluno já cursou ou está cursando as disciplinas de Química Geral, Inorgânica e já foi iniciado nas práticas elementares de um laboratório químico. Há, portanto condições para a realização de uma discussão conceitual a respeito de equilíbrios químicos, e aprofundamentos teóricos e práticos relacionados a fundamentos essenciais como teoria de equilíbrio ácido-base, precipitação, complexação e óxido-redução.

Nas aulas de Química Analítica Qualitativa, o aluno é iniciado nos métodos da análise sistemática através do estudo de cátions e ânions, no que consistem suas classificações e reações. Nestas sequiências de aulas são discutidos os procedimentos de como tratar os produtos de cada reação, no que tange diferenciação entre os cátions e ânions: quais os reagentes que distingue um cátion de um mesmo grupo e quais procedimentos e/ou ensaios distinguem os ânions. Na classificação ainda dos ânions estão presentes as reações que compõe os ensaios confirmatórios.

Para fins de análise qualitativa sistemática, os cátions são classificados em grupos, tomando-se por base sua peculiaridade a determinados reagentes, ou seja, os íons de comportamento análogo são reunidos dentro de um grupo. Os reagentes usados para a classificação dos cátions mais comuns são o ácido clorídrico, o ácido sulfídrico (sulfeto de hidrogênio), o sulfeto de amônio e o carbonato de amônio. A classificação baseia-se no modo como os cátions reagem a tais substâncias pela formação ou não de precipitados.

Ydi e Lisboa (2003) em seu artigo de pesquisa "Uma proposta para o desenvolvimento integrado das disciplinas Química Analítica Qualitativa e Química Inorgânica fundamentado 
em projetos e valores", demonstram como uma metodologia de ensino pode romper a visão tradicional, analítico-reduzicionista, que fragmenta a Química cada vez mais em áreas e disciplinas e se contrapõe a uma visão mais sistêmica, hoje indispensável para a compreensão do mundo, o exercício da cidadania e para a boa qualidade da atuação profissional, seja no magistério, seja na indústria ou na pesquisa acadêmica. Afirmam ainda que a avaliação, nesta proposta, não é feita para "medir" conteúdos, mas, principalmente, para julgar valores, possibilitando reavaliar a orientação da estratégia de desenvolvimento. Assim, o principal papel do professor é o de orientar e ser mediador para o desenvolvimento da atividade chamada por eles de projeto $^{(2)}$.

Nessa abordagem, o primeiro passo é levar o aluno a não depender dos roteiros prontos. Para isso, é necessário colocá-lo diante de um problema. Nesse caso, a orientação do professor é importante para induzi-lo à montagem de uma estratégia de análise. O primeiro passo é delinear o histórico da amostra e seus possíveis componentes. Depois, buscar quais são os possíveis testes para cada componente, confrontando tais procedimentos e resultados no sentido de prever se haverá interferências. Procede-se então a análise. A última etapa é a apresentação dos resultados por meio de relatórios. Essa dinâmica é tipicamente utilizada no desenvolvimento das ações que auxiliam na resolução do problema (GOGUELIN, 1994), ainda que, no momento, estes sejam simples e resolva-se um curto período de tempo, mas com o intuito de familiarizar o aluno com uma nova forma de trabalho.

Segundo Abreu (2006), analisando a grade curricular dos cursos de Química das principais universidades públicas brasileiras, observa-se que grande parte ainda oferece a

\footnotetext{
(2) Simone Jaconetti Ydi é Professora Doutora de Química Analítica Qualitativa do Colegiado de Química da Faculdade de Filosofia, Ciências e Letras do Centro Universitário Fundação Santo André, juntamente com Julio Cezar Foschini Lisboa, Professor Mestre de Química Inorgânica, também consultor da SBQ (Sociedade Brasileira de Química) para a revista Química Nova, referente à seção sobre experimentação no Ensino de Química. Estes professores desenvolveram uma proposta para o ensino integrado de Química Analítica Qualitativa e Química Inorgânica fundamentado em projetos, o que, segundo os autores, permite melhorar a formação do futuro profissional porque propicia uma visão sistêmica da Química e desenvolve a capacidade de trabalhar em equipe e resolver problemas.
} 
disciplina de Química Analítica Qualitativa. Além disso, verificou-se, por meio das ementas dessa disciplina dos diversos cursos, que ela ainda é ensinada da maneira tradicional, com abordagem de cátions e ânions. Abreu e seu grupo de pesquisa acreditam que isso torna os cursos de análise qualitativa extensos, maçantes e não levam o aluno a uma aprendizagem verdadeiramente significativa.

Entretanto, um currículo de Química Analítica Qualitativa que aborde o conteúdo de pesquisa de cátions e ânions e coloque o aluno em condição de aproximar a teoria descrita nos livros, procedimentos e demais referências torna-se importantíssimo para a formação das competências e habilidades deste futuro profissional. Na maioria dos currículos chamados tradicionais, os conceitos são confundidos com definições, que o aluno passa a usar de maneira mecânica em problemas de tipos bem determinados. Aprender a usar uma definição não implica a aprendizagem do conceito, que só será possível após a aplicação do conceito a diferentes fenômenos, nos quais as relações conceituais vão tornando-se explicitas. (MORTIMER, 2003).

Em muitos contextos, os procedimentos são inteiramente adequados e necessários. Os métodos tornam-se rituais quando passam a ser um substituto para o entendimento dos princípios subjacentes. O ensino experimental e do ritual analítico torna-se um verdadeiro dogma para explicar a estabilidade dos compostos químicos, substituindo princípios mais gerais como as variações de energia envolvidas na formação de ligações químicas entre átomos. Esse e outros fatos contribuem para aprofundar o pouco apreço pela Química Analítica entre os estudantes que a vêem como algo desinteressante e sem sentido, que apenas exige esforço de memória, justamente porque não há espaço para a argumentação, discussão e compreensão real do fenômeno.

No ensino tradicional, o experimento, quando existe, é geralmente separado da teoria e serve apenas para comprová-la. As aulas práticas envolvem procedimentos muito bem 
definidos, que o aluno segue como uma receita para chegar a um resultado que já se sabe qual é, antes mesmo de iniciar o experimento. Não há espaço para dúvidas, erros, acaso, intuição. Os resultados, muitas vezes, são forjados para adaptá-los ao que estava previsto na teoria. Além disso, a principal função atribuída ao experimento é aumentar a motivação dos alunos, envolvê-los mais com a disciplina. Estudos mostram que nem sempre isso acontece e que os alunos consideram esse tipo de aula experimental desinteressante. (MORTIMER, 2003).

O currículo de Química Analítica Qualitativa assume então um importante papel na formação do Químico seja ele técnico, bacharel ou licenciado, pois proporciona, através do estudo das reações químicas e marchas analíticas, uma possibilidade para, não somente compreender como uma teoria é formada, mas condições para questioná-la, para interagir com procedimentos, com referenciais teóricos e principalmente, o exercício da argumentação que levará o aluno a apropriar-se das definições e aplicá-las a diferentes fenômenos, formando assim um conceito que tenha significado e o capacite para a resolução de problemas tecnológicos (industriais e de pesquisa) que enfrentará ao longo de sua vida profissional.

Somente um ensino descritivo, matemático e com práticas instrumentais não é suficiente para a formação do Químico, mas estes saberes associados sim ao desenvolvimento da capacidade de argumentação pela apropriação dos conceitos teóricos que se contraponham às questões fenomenológicas. Por esta razão, a compreensão do desenvolvimento histórico da Química e da Ciência através da experimentação possibilita o entendimento da formação das práxis da Química Analítica, bem como a estruturação das marchas analíticas.

Isto tudo só pode ser observado e compreendido com práticas didáticas que tenham como propósito o desenvolvimento das funções cognitivas do raciocínio, através de um exercício da dialética (CASTORINA; BAQUERO, 2008), da argumentação (TOULMIN, 1958; 2004) e do discurso (BAKHTIN, 1986; 1993), através da estruturação das zonas do perfil conceitual (MORTIMER, 2006), superação dos obstáculos epistemológicos 
(BACHELARD, 1938; 1996), que leve os alunos à formação do pensamento reversível e antecipatório como consequiência da capacidade cognitiva lógico-formal (PIAGET, 1975), desenvolvendo então um conjunto de ações didáticas e pedagógicas intencionais na disciplina de Química Analítica Qualitativa dentro do currículo dos cursos de Química.

A Química, tal como a conhecemos hoje, é resultado de uma grande quantidade de heranças que, concretizadas em ofícios, influíram na vida cotidiana de todas as culturas. Não deixa de ser surpreendente que práticas tão diferentes como a do ferreiro, da metalurgia, do curandeiro, da farmácia, do oleiro, da cerâmica, do padeiro, da biotecnologia tenham podido reunir-se e terminar por fundirem-se em um campo comum: a Química, na qual a transformação da matéria é estudada, praticada e transmitida. (ISQUIERDO, 2001). O Ensino de Química torna-se então fundamental para a formação dos mais diversos profissionais que atuarão em diferentes segmentos, mas que terão em comum a competência e habilidade de transformar e controlar as transformações da matéria. 


\section{CAPÍtULO 2}

\section{O pensamento reversível e a argumentação nas aulas de Química Analítica Qualitativa}

Ensinar Química requer um meio e um método particular, de uma forma específica de medir, de calcular, quantificar e principalmente com o uso de uma linguagem própria (CHAMIZO, 2005) ou também mediante uma lógica particular (JENSEN, 1998) e uma filosofia específica (SCERRI, 2001). A visão acumulativa e reduzida da ciência própria do positivismo lógico $^{(3)}$ foi severamente questionada desde os anos 1960, particularmente por Kuhn (1970), Toulmin (1972) e Laudan (1977), sendo que, Toulmin e Laudan, com uma proposta de que a ciência avança por meio da resolução de problemas, e Kuhn por sua interpretação do avanço da ciência a partir de processos revolucionários nos quais uma comunidade científica abandona um paradigma para assumir outro. (CHALMERS, 1999).

As contribuições provenientes das ciências cognitivas nos últimos anos têm construído um mínimo, mas certeiro, consenso sobre outras formas de enfrentar os processos de aprendizagem. (DUSCHL, 1994). Assim, para (re)significar o Ensino de Química Analítica Qualitativa, é indispensável aspirar por docentes, que ensinem "o pensar" com uma metodologia que leve os alunos a uma aprendizagem significativa. Não é suficiente aprofundar-se no conhecimento específico da disciplina (embora sem dúvida, seja fundamental) apenas reproduzindo métodos e procedimentos. Além disso, é necessário incorporar a reflexão, crítica e, sobretudo, argumentação sobre a estrutura da Química, da Ciência e o papel que estas têm em nossa sociedade e, principalmente, é necessário discutir dinâmica de mudança, posto que o que se quer conseguir é que os conhecimentos dos alunos

\footnotetext{
${ }^{(3)}$ O positivismo é produto da filosofia de Augusto Comte (séc. XIX), que considera o estado positivo o último e mais perfeito estado atingido pela humanidade. Valoriza a ciência como a forma mais adequada de conhecimento, donde deriva o cientificismo que é a forma de pensar pela qual o único conhecimento adequado é o científico: concepção deformada da ciência que consiste em torná-la como sistema fechado e definitivo e como solução de todos os problemas. (ARANHA, 1986, p. 426, 430).
} 
evoluam até torná-los mais rigorosos e úteis. Para isso, é necessário escolher, dentre a enorme quantidade de metodologias e pedagogias aquela que permita desenvolver as competências requeridas em um mundo cada vez mais cambiante e que, pelo menos, prepare melhor o estudante para um futuro que não está predeterminado, exercendo com plenos saberes sua profissão: o ser Químico.

Esta escolha só poderá ocorrer se houver por parte dos docentes uma verdadeira prática reflexiva. (PERRENOUD, 2002, p.13). Essa postura deve-se tornar quase permanente, inserir-se em uma relação analítica com a ação, a qual se torna relativamente independente dos obstáculos encontrados ou das decepções. Uma prática reflexiva pressupõe uma postura, uma forma de identidade, um hábito. Sua realidade não é medida por discursos ou por intenções, mas pelo lugar, pela natureza e pelas conseqüências da reflexão no exercício cotidiano da profissão, seja em situação de crise, estagnação ou de fracasso, seja em situação de prosperidade, sucesso e velocidade de cruzeiro.

O profissional reflexivo é uma antiga figura da reflexão sobre a educação, cujas bases podem ser encontradas em Dewey, sobretudo na noção de reflective action (DEWEY, 1933, 1947, 1993). Encontra-se esta idéia - e não esta expressão - em todos os grandes pedagogos que, cada um a seu modo, considerou o professor ou o educador um inventor, um pesquisador, um improvisador, um aventureiro que percorre caminhos nunca antes trilhados e que pode se perder caso não reflita de modo intenso sobre o que faz e caso não aprenda rapidamente com a experiência.

Quando se diz que um professor tem dez anos de experiência, será que tem mesmo? Ou tem um ano de experiência repetido dez vezes? Só uma reflexão sistemática e continuada é capaz de promover a dimensão formadora da prática. Apenas ler sobre as novas teorias pedagógicas não é suficiente para se manter atualizado. Mais importante do que formar é formar-se; todo conhecimento é autoconhecimento; toda formação é autoformação. (NÓVOA, A. O professor se forma na Escola. In: Escola Pública $e$ Sociedade. São Paulo: Saraiva/Atual, 2002). 
A prática reflexiva leva a compreender o papel central dos problemas no avanço da ciência, pois a resolução dos problemas requer reflexão, crítica e argumentação. Esta prática não é prerrogativa apenas do professor, mas é a partir de uma ação reflexiva da ação docente que este será capaz de formar profissionais reflexivos, quer sejam para a atuação como técnicos, licenciados, bacharéis ou pesquisadores. É partir das atividades reflexivas e questionadoras que o aluno poderá compreender que estas características contribuem para o entendimento e desenvolvimento da Ciência. Toulmin (2004) propõe uma composição analítica de caracterização dos problemas por meio da expressão:

\section{PROBLEMAS = (IDEAIS EXPLICATIVOS $)-($ CAPACIDADES CORRENTES $)$}

Assim, os problemas se apresentam na "distância" que há entre aquilo que uma comunidade ou indivíduo aspira compreender (o que é denominado "ideais explicativos") e a capacidade que tem essa comunidade ou indivíduo para alcançá-lo (capacidades correntes). Essa distância é diminuída ou desaparece quando emergem novos conhecimentos. Entretanto, essa aspiração é concretizada geralmente mediante perguntas, e estas que concretizam os problemas são perguntas do cotidiano.

$\mathrm{Na}$ atividade experimental realizada pelos alunos nesta pesquisa a pergunta premente é: qual cátion e qual ânion formam a substância em análise? Esta pergunta surge inicialmente numa proposta de ensino de Química Analítica Qualitativa com finalidade didática, mas em brevíssimo tempo surgirá novamente num contexto profissional, quer para uma investigação em controle de qualidade, em desenvolvimento de produtos, em gestão ambiental ou em química forense.

Uma situação particular, vivenciada num contexto profissional, que bem ilustra a caracterização do problema idealizado por Toulmin, ocorrida no ano de 2005, desenrolou-se 
num Centro de Pesquisa de uma indústria cosmética e demonstra que as situações didáticas antecipam as realidades profissionais.

\begin{abstract}
Um dos produtos fabricados pela indústria cosmética era um creme alisante para cabelos acompanhado por uma loção neutralizante, cuja fórmula era composta basicamente por peróxido de hidrogênio (água oxigenada na concentração de 20 volumes) e silicone para reparação dos fios. O problema enfrentado pela equipe de técnicos e pesquisadores era que o sache em que a loção neutralizante era comercializada, em aproximadamente um mês, apresentava estufamento, chegando até a romper-se, derramando o produto. Isto gerou o recolhimento de vários lotes e por meses os pesquisadores responsáveis trabalharam neste projeto tentando diagnosticar a causa. Ao ouvir uma das discussões a respeito das ações já realizadas, notei que a argumentação estava associada ao processo de fabricação, à embalagem, à temperatura de armazenamento, ao transporte e outras hipóteses, mas não se leva em conta que efetivamente estava havendo uma reação química de decomposição da água oxigenada não por mera desestabilização da fórmula. Ignoravam que a presença de uma determinada espécie química deveria provocar a decomposição do peróxido. Surge então a pergunta: qual substância química é responsável por isto? Propus então que investigassem a presença de ferro III $\left(\mathrm{Fe}^{3+)}\right.$ na formulação, o que de início foi refutado pelos pesquisadores que alegaram que o reator era de aço inox e o sache formado por um filme de alumínio e polímeros. Questionei então que o $\mathrm{Fe}^{3+}$ poderia ser proveniente de alguma matéria-prima e conduzi uma pequena marcha analítica para este cátion. Surpreendi-me, ao receber uma amostra do silicone utilizado na formulação com a presença de uma pequena quantidade de um fino pó cinza depositado no fundo do frasco. Os pesquisadores responsáveis por este produto me informaram que isto era normal. Ao proceder a análise de identificação, verifiquei que se tratava de ferro (ainda no estado metálico), mas que era facilmente oxidado a $\mathrm{Fe}^{3+}$, principalmente na presença de peróxido de hidrogênio, o que gerava a decomposição deste produto produzindo oxigênio gasoso. Ao observar a especificação do produto e os limites para ferro na matéria-prima, notei que este item não fazia parte da negociação da especificação comercial com o fornecedor.
\end{abstract}

Este episódio bem caracteriza que o problema existia pela grande distância que havia entre os ideais explicativos e a capacidade corrente para resolvê-los. Se houvesse, portanto uma mobilidade antecipatória e uma reversibilidade do pensamento durante o desenvolvimento do produto, evocando fundamentos básicos da Química Analítica para a composição da especificação técnica, provavelmente a distância entre os ideais explicativos e as capacidades correntes seriam menores, o que levaria o problema à nulidade.

As perguntas e suas soluções, os problemas de seu tempo, as leis e os modelos que permitem reconhecer padrões e teorias sobre o mundo, formam parte de uma atividade 
humana (a dos cientistas), que inclui o que estes fazem em seus laboratórios e a maneira como vivem as perguntas que se fazem e como tentam respondê-las. Assim, os conceitos aprendidos na aula de Química são os resultados de muitas perguntas, de problemas resolvidos e de problemas sem resolver, de aplicações mais ou menos afortunadas que foram enigmas em seu momento, justamente porque o conhecimento e os conceitos gerados são produtos das respostas obtidas na resolução dos problemas enfrentados pela comunidade científica, da qual o aluno, pelo estudo da Química, passa a fazer parte. Por isso, estes problemas e suas respostas integram uma complexidade tal que é necessário distinguir neles três características ou dimensões que, assim como permitiram construí-los, vão permitir utilizá-los: a linguagem, as técnicas de representação e os procedimentos de aplicação. (DRIVER, 2000). Estas são dimensões que constituem os métodos de pesquisa analítica e os referenciais teóricos utilizados no Ensino de Química Analítica Qualitativa.

A linguagem e as técnicas de representação referem-se àqueles aspectos simbólicos da explicação científica (o explicar o fato, que pressupõe compreendê-lo), uma das formas nas quais tornamos público o pensamento, uma das formas na qual uma geração transmite a outra o conteúdo de uma ciência, uma enculturação ${ }^{(4)}$. Estes só têm um uso genuinamente explicativo quando são aplicados no mundo. Assim, os procedimentos de aplicação, compreendem o reconhecimento de situações em que é possível utilizar tal conhecimento para a resolução de um determinado problema (CHAMIZO, 2008), quer seja, uma pesquisa no desenvolvimento de um produto, no controle de qualidade de um processo industrial ou em tantas outras aplicações tecnológicas dos conhecimentos da Química Analítica.

\footnotetext{
(4) Enculturação é o processo pelo qual o individuo entra em contato com os elementos que constituem determinada cultura. A adoção desta perspectiva sociocultural tem implicações importantes para o ensino formal. Esta perspectiva de aprendizagem vem sendo adotada nas pesquisas em educação em Ciências, podendo citar os trabalhos de Driver e Newton, 1999; Roth, 1999; Mortimer, 2000; Reigosa Castro e Jiménes Aleixandre, 2000; Lemke, 2003, entre outros que trouxeram novas contribuições para a área. Entre elas, a valorização do papel do professor na mediação entre os conhecimentos cotidiano e científico, e a necessidade de pesquisas sobre as linguagens empregadas em sala de aula. (CAPECCHI, 2004, p. 21).
} 


\subsection{O pensamento reversível e as estruturas lógicas}

Como discutido até o momento, esta pesquisa tem como proposta o estudo da argumentação dos alunos na resolução de problemas de Química Analítica Qualitativa, no qual se investiga o raciocínio e a formação do pensamento reversível e antecipatório numa estrutura lógico-formal das capacidades cognitivas dos alunos. Estabelece-se então uma (re)significação das práticas didáticas da disciplina de Química Analítica Qualitativa como ferramenta na formação desta competência e habilidade para o capacitação do profissional da Química. Compreender então os estudos de Jean Piaget e suas propostas a respeito da gênese e estruturação do conhecimento é importante para fundamentarmos o conceito de reversibilidade do pensamento tratado neste trabalho.

Uma das proposições de Piaget e Inhelder (1959) foi que, na fase de classificação operatória, haveria uma estreita relação entre a mobilidade retroativa que se manifesta pela alteração de critérios na classificação efetiva de um objeto. A mobilidade antecipatória manifesta-se pela alteração do planejamento mental que antecedem a classificação efetiva. $\mathrm{O}$ pensamento lógico obedece a uma graduação de integrações de dados objetivos que convergem para o estabelecimento final das estruturas que evidenciam o emprego dos conceitos básicos de gênero próximo e diferenças específicas. Da percepção ao juízo lógico há um longo percurso a ser examinado, em cuja extensão instala-se a gênese das estruturas lógicas elementares, a qual é discutida na obra de Jean Piaget (1959) em que fundamenta o conceito de mobilidade retroativa como capacidade do indivíduo de remodelar e alterar critérios e executar aquilo que se planeja adequadamente.

A mobilidade retroativa (ou pensamento reversível) é traduzida pela capacidade do indivíduo de intervir em uma propriedade notada mais recentemente ou de novos elementos a juntar-se às coleções anteriores. Pode-se ainda descrever a mobilidade antecipatória, 
manifestando-se sob a forma de planos interiores de classificação que precedem a manipulação efetiva e, sobretudo, sob a forma de uma opção entre várias possibilidades possíveis, de maneira a alcançar, sem hesitações exteriores, o mais adequado. (PIAGET, 1975).

Ao estudar a reversibilidade do pensamento, Piaget afirma que o sujeito no estágio das “coleções figurais" não antecipa, praticamente, nenhuma das suas classificações efetivas, elaborando-as, isso sim, durante o desenrolar da própria ação e mediante sucessivas aproximações. Para estabelecermos uma relação destas teorias e com o Ensino de Química Analítica Qualitativa, traremos uma transcrição do diálogo entre um dos alunos e o professor/pesquisador, coletado através do registro em vídeo, os quais são os dados desta pesquisa. O episódio $22(567 \text { a } 602)^{(5)}$ aponta estes conceitos propostos por Piaget a respeito do estágio em que se encontra o sujeito, bem como as sucessivas aproximações que o levarão a uma reversibilidade e antecipação do pensamento.

567. $\mathrm{P}^{(6)}$ : Eu queria que vocês argumentassem quais são, quais foram as reações, que conclusões vocês chegaram?

568. Wendel: De todas as reações que a gente fez, a gente eliminou o tiocianato, o tiossulfato, esse fluoreto nem conta, o sulfato e os carbonatos.

569. Renato: Certo!

570. Wendel: Ai sobraram três: os cloretos, os iodetos e os brometos.

571. Renato: O iodeto, ao reagir com a prata tinha que causar um precipitado amarelo e floculento. Quando reagimos...

Renato pega o tubo de ensaio contendo a reação.

572. Wendel: Ficou um precipitado branco.

573. Renato: Então sobrou qual? Os cloretos e brometos.

574. Wendel: Quando a gente foi fazer o teste com brometo, a gente notou que tinha...

\footnotetext{
${ }^{(5)}$ No item 2.2 deste capítulo e no capítulo 3 será apresentada a metodologia utilizada para a coleta dos dados desta pesquisa, sua forma de organização, bem como a metodologia de transcrição das falas que estão descritas na íntegra no Anexo 1.

(6) A letra "P" foi utilizada para designar a fala do professor/pesquisador na transcrição do diálogo das atividades experimentais.
} 
575. Renato: Com o cloreto, nós vimos aqui... [começa a procurar no Vogel]... que seria branco e floculento. Confirmando o resultado.

576. Renato: Pra confirmar, se não era um brometo, o que nós fizemos: viemos aqui no Vogel e analisamos o que está escrito em brometos quando reagido com nitrato de prata, ele seria um precipitado amarelo pálido. Então eliminamos o brometo...

577. Claudinei: E os iodetos. E chegamos ao ânion.

578. Renato: Descobrimos que a amostra seria o cloreto de lítio.

579. P: E como vocês chegaram à conclusão que é o lítio?

580. Renato: Devido à coloração do ensaio de chama.

581. Wendel: Era uma coloração avermelhada, com um laranja bem fraco.

582. P: E vocês não fizeram nenhum teste via úmida para testar lítio?

583. Renato: Via úmida para lítio não.

584. P: Vocês poderiam chegar a uma conclusão decisiva que o cátion é o lítio só pelo ensaio de chama?

585. Renato: Creio que não.

586. P: Quais são os interferentes de um ensaio de chama?

587. Wendel: A contaminação?

588: P: Contaminação do quê? Da amostra? Do fio?

589. Renato: Do fio.

590. P: Do fio.

591. Wendel: Mas para não ter esta dúvida nós fizemos o teste várias vezes, limpamos o fio várias vezes para podermos tirar esta conclusão que seria este lítio.

592. P: A cor do espectro no ensaio de chama é facilmente perceptível a olho nu ou não?

593. Renato: Não!

594. P: O analista pode se enganar?

595. Wendel e Renato: Sim, pode.

596. Wendel: Sim, ocorreu, tanto que no ensaio de chama a gente estava analisando baseado no branco da folha e no branco do jaleco e o Claudinei estava falando que estava vendo um amarelo, então eu mostrei pra ele de novo que só tinha o vermelho e o laranja na base.

597. P: Então vocês teriam que fazer um ensaio via úmida pra confirmar se é lítio?

598. Wendel: Sim, pra confirmar se é lítio.

599. P: E vocês não fizeram?

600. Wendel: Não fizemos.

601. P: Pretendem fazer?

602. Wendel: A gente vai fazer agora.

Começam então a procurar no Vogel um ensaio via úmida para o lítio. 
Inversamente, uma vez construída a sua primeira classificação figural, o sujeito como que fica amarrado a ela por uma espécie de perseverança e não consegue, por falta de mobilidade retroativa, modificar os seus critérios ou superar a sua realização inicial, vemos isto quando os alunos concluem tratar-se de lítio apenas pelo ensaio de chama e pela observação das cores do espectro, todavia, quando questionados, demonstram saber que este ensaio não pode ser tratado como conclusivo e sim um indício. O questionamento do professor causa então uma hesitação exterior que provoca uma reestruturação dos planos mentais e elaboração de novas ações. Mas o sujeito da fase das “classificações operatórias" só passa a ação em função de esquemas antecipatórios e mostra-se sempre disposto, sem que tenha de contradizer-se a respeito dos planos já realizados (601 e 602), a modificar os seus critérios ou a incorporar suas construções iniciais em outras mais amplas e mais compreensivas.

Visto a importância da análise das etapas da mobilidade retroativa do pensamento, Piaget propõe então um estudo para avaliar suas duas formas complementares. A mobilidade é então, simultaneamente retroativa e antecipatória e no contexto geral do qual se elabora esta estrutura fundamental que é a reversibilidade antecipatória, os progressos contínuos dessa mobilidade correspondem aos graus de estruturação operacional (a partir da ação irreversível e até a reversibilidade lógica, mas passando por uma série de formas semi-reversíveis, depois quase reversíveis).

Os estudos realizados por Piaget de tais antecipações foram denominados visuais, com classificações chamadas por ele de "táteis", porque os objetos a classificar só são dados ao sujeito por vias tátil-cinestésicas. Todavia, pode-se estudar tanto as seriações táteis como as visuais e pode-se provocar a remodelação das últimas mediante a anterior introduzindo elementos novos. Esta relação chamada por Piaget de "tátil-cinestésica" é compreendida na práxis de Química Analítica Qualitativa quando, para a determinação de um halogênio utiliza- 
se como reagente de grupo o cátion prata $\left(\mathrm{Ag}^{+}\right)$. Todos os halogênios, com exceção do fluoreto, na presença de prata precipitam, esta é então uma generalização que é refinada e remodelada pela introdução de uma questão cinestésica-visual que é a cor do precipitado (figura 6). Este é o conceito que os alunos se apropriam para estabelecer o plano de ação exposto nos argumentos 576 e 577 do exemplo anterior.

Os efeitos de incorporações sucessivas de elementos exigem uma reorganização das classes já constituídas. Todas as estruturas cognitivas conhecem certos efeitos temporais: ações exercidas por uma estrutura anteriormente percebida ou concebida sobre uma estrutura percebida ou construída anteriormente, quando existem relações suficientes (de analogia, de vizinhança espaço temporal etc.) entre essas estruturas sucessivas. Esses efeitos temporais podem constituir em persistências, em transportes temporais (com identificações ou contrastes), em transposições ou transferências de diversas formas (com ou sem antecipações) e, finalmente, em generalizações. Ora, contrariamente aos níveis perceptivos e sensóriomotores elementares, onde essas ações se revestem, quase exclusivamente, de um sentido único (uma percepção anterior modifica a seguinte, mas esta não se reflete sobre aquela), os numerosos intermediários que conduzem da transposição ou da transferência sensório-motora à generalização conceitual de nível operatório dão lugar a novas possibilidades caracterizadas pela intervenção do sentido dos efeitos temporais. De fato, se as mais simples formas de generalização consistem em assimilar o novo ao antigo, as formas superiores apresentam, pelo contrário, a propriedade de duplicar esse processo assimilador mediante um processo do pensamento reversível (retroativo) de tal ordem que os novos elementos possam igualmente conduzir a uma reorganização de todo o sistema a que estão assimilados, até o ponto em que se modifiquem até os conceitos e conhecimentos anteriores. Numerosas combinações são então possíveis, das quais a mais equilibrada consiste no seguinte: a reorganização nada destrói da estrutura anterior, mas logra, outrossim, integrá-la ao máximo em uma nova 
estrutura que compreenderá então dois subsistemas, o antigo e novo, reunidos em uma estrutura total que conserva a anterior a título de caso particular.

O Ensino de Química Analítica Qualitativa e as propostas experimentais da disciplina contribuem para que, através da argumentação, o professor possibilite ao aluno a maturação de suas estruturas cognitivas e exercite, através da prática experimental, a reversibilidade e antecipação do pensamento, apropriando-se de conhecimentos teóricos, registrados nos livros e procedimentos, havendo então um ambiente didaticamente construído para que se domine a linguagem e dela se faça uso, compreendendo os diversos conceitos da Química e da Ciência, dando então real significado a eles.

\subsubsection{Os estágios do desenvolvimento humano}

Piaget considera quatro períodos no processo evolutivo da espécie humana que são caracterizados "por aquilo que o indivíduo consegue fazer melhor" no decorrer das diversas faixas etárias ao longo do seu processo de desenvolvimento. (FURTADO, 1999).

Cada uma dessas fases é caracterizada por formas diferentes de organização mental que possibilitam as diferentes maneiras do indivíduo relacionar-se com a realidade que o rodeia. (COLL, 1987). De uma forma geral, todos os indivíduos vivenciam essas fases na mesma sequiência, porém o início e o término de cada uma delas pode sofrer variações em função das características da estrutura biológica de cada indivíduo e da riqueza (ou não) dos estímulos proporcionados pelo meio ambiente em que ele estiver inserido. Por isso mesmo é que a divisão nessas faixas etárias é uma referência, e não uma norma rígida. (FURTADO, 1999).

Segundo La Taille (2003), Piaget usa a expressão “a passagem do caos ao cosmo" para traduzir o que o estudo sobre a construção do real descreve e explica. De acordo com Piaget, a 
criança nasce em um universo para ela caótico, habitado por objetos evanescentes (que desapareceriam uma vez fora do campo da percepção), com tempo e espaço subjetivamente sentidos, e causalidade reduzida ao poder das ações, em uma forma de onipotência. Assim sendo, o universo que circunda a criança é conquistado mediante a percepção e os movimentos.

Este conceito de objetos evanescentes no Ensino de Química é bem compreendido quando se inicia o estudo de solubilidade. Ao adicionar uma substância sólida, por exemplo, um sal na água, se este for solúvel, haverá uma interação de nível atômico-molecular chamada de solvatação, o que leva a substância ao "desaparecimento" no líquido que se torna, conceitualmente, uma solução. A substância adicionada encontra-se no sistema, mas apresenta-se de outra forma, mas para compreender este conceito é necessária uma estruturação cognitiva sensório-motor. Da mesma forma que, para compreender uma representação simbólica de um fenômeno representado num procedimento, o aluno precisa desta estrutura para argumentar a respeito dele.

Para Piaget, o que marca a passagem do período sensório-motor para o pré-operatório é o aparecimento da função simbólica ou semiótica, ou seja, é a emergência da linguagem. Nessa concepção, a inteligência é anterior à emergência da linguagem e por isso mesmo não se pode atribuir à linguagem a origem da lógica, que constitui o núcleo do pensamento racional. (COLL, 1987). Na linha piagetiana, desse modo, a linguagem é considerada como uma condição necessária, mas não suficiente, ao desenvolvimento, pois existe um trabalho de reorganização da ação cognitiva que não é dado pela linguagem, conforme elucida La Taille (1992). Em uma palavra, isso implica entender que o desenvolvimento da linguagem depende do desenvolvimento da inteligência.

Todavia, conforme demonstram as pesquisas psicogenéticas descritas por La Taille, Furtado, Castorina e Baquero (2008), a emergência da linguagem acarreta modificações 
importantes em aspectos cognitivos, afetivos e sociais, uma vez que ela possibilita as interações interindividuais e fornece, principalmente, a capacidade de trabalhar com representações para atribuir significados à realidade. Tanto é assim, que a aceleração do alcance do pensamento neste estágio do desenvolvimento, é atribuída, em grande parte, às possibilidades de contatos interindividuais fornecidos pela linguagem.

Contudo, embora o alcance do pensamento apresente transformações importantes, ele caracteriza-se, ainda, pelo egocentrismo, uma vez que o indivíduo não concebe uma realidade da qual não faça parte, devido à ausência de esquemas conceituais e da lógica. Assim, neste estágio, embora o sujeito apresente a capacidade de atuar de forma lógica e coerente (em função da aquisição de esquemas sensoriais-motores) ele apresentará, paradoxalmente, um entendimento da realidade desequilibrado (em função da ausência de esquemas conceituais), conforme salienta Rappaport (1981).

As aulas de Química Analítica Qualitativa devem ser organizadas para possibilitar a interação entre o discurso científico da Química e o discurso cotidiano. Para que isto aconteça é preciso que o discurso científico faça sentido para o aluno, visto que o aluno domina a linguagem comum, mas não a linguagem científica. Na concepção desta pesquisa, isto poderia ser alcançado tanto problematizando suas idéias informais quanto criando contextos que sejam significativos para ele. É importante a percepção de que a linguagem científica tem características próprias que a distinguem da linguagem comum. Essas características não foram inventadas em um momento determinado. Ao contrário, foram sendo estabelecidas ao longo do desenvolvimento científico, da História da Química e da Ciência, como forma de registrar e ampliar o conhecimento. Estas características, muitas vezes, tornam a linguagem científica estranha e difícil para os alunos. Reconhecer estas diferenças implica admitir que a aprendizagem da ciência é inseparável da aprendizagem da linguagem. 
As operações concretas são caracterizadas pela capacidade do indivíduo de estabelecer relações e coordenar pontos de vista diferentes (próprios e de outrem) e de integrá-los de modo lógico e coerente. (RAPPAPORT,1981). Outro aspecto importante neste estágio referese ao aparecimento da capacidade do sujeito de interiorizar as ações, ou seja, ela começa a realizar operações mentalmente e não mais apenas através de ações físicas, típicas da inteligência sensório-motor (se lhe perguntarem, por exemplo, se uma determinada substância é mais solúvel em água fria ou em água quente, ele será capaz de responder acertadamente comparando-as mediante a ação mental, ou seja, sem precisar medi-las usando a ação física).

Contudo, embora o aluno consiga raciocinar de forma coerente, tanto os esquemas conceituais como as ações executadas mentalmente se referem, nesta fase, a objetos ou situações passíveis de serem manipuladas ou imaginadas de forma concreta. Além disso, conforme pontua La Taille (1992) se no período pré-operatório o sujeito ainda não havia adquirido a capacidade de reversibilidade, ou seja, a capacidade de pensar simultaneamente o estado inicial e o estado final de alguma transformação efetuada sobre os objetos (por exemplo, a ausência de conservação da quantidade quando se transvaza o conteúdo de um copo A para outro B, de diâmetro menor), tal reversibilidade será construída ao longo dos estágios operatório concreto e formal. É por conta deste desenvolvimento que as atividades de experimentação no Ensino de Química Analítica são fundamentais para a estruturação do pensamento e do raciocínio dos alunos, pois possibilitam a construção desta reversibilidade.

As operações formais do raciocínio levam o aluno a ampliar as capacidades conquistadas ao longo dos processos de aprendizagem. O sujeito já consegue raciocinar sobre hipóteses na medida em que ele é capaz de formar esquemas conceituais abstratos e através deles executar operações mentais dentro de princípios da lógica formal. Com isso, conforme aponta Rappaport (1981) o aluno adquire capacidade de criticar um determinado 
procedimento, metodologia, reagentes e equipamentos utilizados numa análise química, adquirindo autonomia.

De acordo com Piaget, ao atingir esta fase, o indivíduo adquire a sua forma final de equilíbrio, ou seja, ele consegue alcançar o padrão intelectual que persistirá de forma amadurecida. Isso não quer dizer que ocorra uma estagnação das funções cognitivas, a partir do ápice adquirido no processo de escolarização. Seu desenvolvimento posterior consistirá numa ampliação de conhecimentos tanto em extensão como em profundidade, mas não na aquisição de novos modos de funcionamento mental. (RAPPAPORT, 1981).

Cabe então problematizar as considerações anteriores de Rappaport, a partir da seguinte reflexão: resultados de pesquisas têm indicado que adultos poucoletrados/escolarizados apresentam modo de funcionamento cognitivo balizado pelas informações provenientes de dados perceptuais, do contexto concreto e da experiência pessoal. (OLIVEIRA, 2001). De acordo com os pressupostos da teoria de Piaget, tais adultos estariam, portanto, no estágio operatório-concreto, ou seja, não teriam alcançado, ainda, o estágio final do desenvolvimento que caracteriza o funcionamento lógico-formal. Como é que tais adultos (operatório-concreto) poderiam, ainda, adquirir condições de ampliar e aprofundar conhecimentos (lógico-formal) se não lhes é reservada, de acordo com a respectiva teoria, a capacidade de desenvolver novos modos de funcionamento mental? Aliás, de acordo com a teoria, não dependeria do desenvolvimento da estrutura cognitiva a capacidade de desenvolver o pensamento reversível e antecipatório? É justamente para que haja possibilidade de desenvolver esta capacidade cognitiva que o Ensino de Química Analítica Qualitativa corrobora na formação do raciocínio do aluno muito mais do que simplesmente ensiná-lo a executar um método analítico.

Novamente a descrição de uma situação particular vivenciada agora num Centro de Pesquisa de uma indústria petroquímica nos auxilia na compreensão de que a simples 
execução de um método analítico requer a reversibilidade e antecipação do pensamento para que a ação, estabelecida anteriormente num planejamento mental, não configure uma mera forma ritualística do procedimento, mas que encerre a compreensão conceitual que envolve a prática.

\begin{abstract}
Observava pelo vidro da divisória uma das técnicas do laboratório de analítica preparar as amostras, as quais eu havia solicitado a análise de determinação do teor de tensoativo de um detergente fabricado com uma das matérias-primas da empresa, o lauril éter sulfato de sódio. Notei que ela pesou-as num balão volumétrico, conforme prescrevia o método de análise, e agitou os balões para que ocorresse a homogeneização do produto. Obviamente, por tratar-se de um detergente, formou-se um volume de espuma que subiu pelo gargalo do balão. Entretanto, me chamou a atenção que, antes de avolumar o balão com água até o menisco, ela introduziu a mangueira da linha de vácuo no balão e succionou a espuma. Após este procedimento, deu continuidade à análise determinando o teor de tensoativo por titulação com Hyamina.
\end{abstract}

Este fato ocorrido em meados de 2003 demonstra que esta profissional da Química não estabeleceu uma relação entre o conceito de tensoativo e a espuma formada, uma vez que grande parte do tensoativo encontra-se na espuma e se sua atividade analítica era determinar o seu teor na amostra, succioná-lo do balão foi um planejamento mental desarticulado e sem nenhum pensamento antecipatório a respeito do resultado esperado. Percebe-se claramente que a estruturação cognitiva operatório-concreta está bem formada, pois o procedimento de pesagem e de avolumar o balão respeitando o menisco estão corretos, mas a retirada da espuma não poderia ser realizada, o que demonstra a falta de reversibilidade do pensamento por parte da analista e também por aquele que redigiu o procedimento analítico que não antecipou esta situação procedimental.

A tarefa cognitiva predominante no período operacional concreto é dominar as operações. Ora, a operação é uma ação interiorizada, que se torna reversível para se coordenar com outras na forma de estruturas operatórias. Assim, as ações podem ser somadas (+), subtraídas $(-)$, divididas $(\div)$, multiplicadas $(\mathrm{x})$, formando sistemas de operações, responsáveis 
pelo aparecimento de noções como substância, peso, volume, espaço, série, classe, número etc., definidas ou expressas, de agora em diante através da linguagem. O sujeito somente constrói essas noções a partir da ação de outros sujeitos sobre os objetos reais, pode-se definir então a inteligência como concreta. (FARIA, 1998).

Durante a construção das estruturas operatórias concretas, o sujeito, diante de objetos novos ou em transformação, age trazendo para o plano consciente duas ou mais de suas características para combiná-las numa síntese mental. A imitação só intervém em função de necessidades inerentes ao trabalho inteligente e, nesse caso, submete-se à própria inteligência - imitação refletida. Isto evidencia a importância das ações do professor que executará inicialmente as práxis da ciência - principalmente no Ensino de Química Analítica - para que o estudante possa estabelecer vínculos mentais com a manipulação dos reagentes, materiais, tubos de ensaios, equipamentos.

(...) o espírito tendo tomado consciência de cada um dos fatores não mais isoladamente, mas em suas relações com os outros, todos agem ao mesmo tempo sobre o conceito e há síntese e hierarquia. (PIAGET, 1967, p. 167).

O sistema de operações, uma vez elaborado, constitui um instrumento para a incorporação do mundo físico e social. Para compreender, por exemplo, que dois copos de tamanhos diferentes têm a mesma quantidade de água, o indivíduo tem de realizar ações sobre essa realidade. Pode-se desta forma, concluir que a quantidade de água do copo grande é a mesma que a de quatro pequenos copos $(\mathrm{A}+\mathrm{B}+\mathrm{C}+\mathrm{D})$ porque adicionou $(+)$ mentalmente as pequenas porções de água contida nos copos pequenos com a porção contida no copo grande. É a construção dos sistemas de operações relativos à conservação de quantidade, às séries, classes, números, espaço etc. que permite a compreensão da realidade e sua nomeação através de palavras, que expressem o conceito. 
Esta articulação mental explicita as ocorrências nas práticas experimentais em pesquisa analítica de cátions e ânions. O estudante deve realizar ações sobre a realidade fazendo projeções e antecipações mentais sobre as ocorrências futuras produzidas pela mistura de um determinado reagente sobre a espécie em análise. Se uma evidência ocorrer há a confirmação da presença de tal espécie iônica no sistema, se não ocorrer esta hipótese será descartada e novo esquema mental deverá ser estruturado.

Piaget (1964), em sua obra "A formação do símbolo na criança", descreve que para certos autores a passagem da inteligência sensório-motora para a inteligência conceitual, explica-se, sem mais nada, pela intervenção da vida social e dos quadros lógicos e representativos já prontos no sistema dos signos e das representações coletivas. O que tem de se encontrar não é apenas a explicação suscetível de penetrar no próprio pormenor dos mecanismos representativos tal, por exemplo, as múltiplas formas de intuições espaciais (ordem, posição, deslocamento, distância etc), até as operações geométricas elementares. Ou para limitar a este exemplo do espaço, é certamente impossível interpretar psicologicamente as estruturas representativas mais evoluídas sem reconhecer uma certa continuidade com o espaço sensório-motor inicial ou o da percepção em geral, que prolonga o precedente.

Quanto ao elemento social que intervém manifestadamente cedo ou tarde em todos os domínios representativos, trata-se de saber ainda segundo quais processos. Desta forma, entendem-se as atividades de laboratório como uma etapa de manipulação e interação com os objetos (substâncias, procedimentos, vidrarias), sociais (pares, professor, comunidade científica, sociedade) para que ocorra a transformação do esquema sensório-motor em conceito. Assim pode-se considerar a socialização e a verbalização dos esquemas como constituindo somente umas das dimensões dessa transformação geral: dessa maneira, as etapas observadas (pelos registros em vídeo desta pesquisa), segundo a dimensão social, serão 
elas esclarecidas pelas fases do processo evolutivo interno que conduz da inteligência sensório-motora à inteligência conceitual.

As formações dos conceitos verdadeiros a partir dos esquemas sensoriais-motores são lentas e requer maturação. (PIAGET, 1964, 1990). A análise dos registros das imagens, dos diálogos e argumentações travados durante as seqüências de aulas investigadas demonstra a validade desta afirmação de Piaget empregada no ensino de Química Analítica Qualitativa.

O conhecimento experimental procede, em contrapartida, por abstração a partir das propriedades do objeto como tal. É de se esperar que o papel do dado percebido possibilite que haja um acréscimo à percepção, o que se acrescenta não é senão, apenas um conjunto de quadros lógicos-matemáticos, mas os produtos da leitura perceptiva. (PIAGET, 1972, 1991).

É fundamental recordar a afirmação de Piaget (1972) em sua obra "Psicologia e Epistemologia" que, se existe um conhecimento lógico-matemático puro, desligado de qualquer experiência, não existe reciprocamente conhecimento experimental que possa ser qualificado como "puro", no sentido desligado de qualquer organização lógico-matemática. A experiência nunca é acessível senão por intermédio de quadros lógicos-matemáticos, constituído em classificações, ordenações, correspondências, funções etc. A própria leitura perceptiva supõem a intervenção desses quadros ou dos seus esboços mais ou menos indiferenciados.

Num extremo há os estudos da Química como ciência experimental que estabelecem uma perpétua assimilação do dado experimental com as estruturas lógico-matemáticas, porque o próprio refinamento da experiência é função dos instrumentos lógico-matemáticos utilizados a título de intermediários necessários entre o sujeito e os objetivos a serem atingidos.

A inteligência age então sobre a própria percepção. A percepção não atua sozinha na formação dos conhecimentos, pois se junta a outras fontes necessárias coordenando-se com 
outros grupos lógico-matemáticos no funcionamento dos sistemas operatórios. (PIAGET, 1972, p. 98). Se a ação e a inteligência transformam, por sua vez, a percepção, e esta, longe de ser autônoma, e cada vez mais intimamente estruturada pelo esquematismo pré-operatório e operatório, então é de considerar que a organização mental dos dados de origem sensorial prefigura a inteligência que é cada vez mais influenciada pelos progressos na manipulação experimental como fonte de percepções para a formação da inteligência e do conceito. Isto justifica então a necessidade das práxis de Química Analítica Qualitativa como práticas de ensino que promovam o aprendizado conceitual e integrador dos conhecimentos necessários para a formação de um Químico, o que desenvolverá sua capacidade de pensar reversivelmente com eficaz mobilidade antecipatória sobre os fenômenos observados.

\subsection{Caracterização dos gêneros discursivos}

Interagir e dialogar em sala de aula é uma prática que requer controle do professor sobre os processos de incorporação de vários discursos e visões de mundo que circulam por este espaço (seja a sala de aula ou o laboratório). É preciso pensar nas oportunidades que podem ser criadas para que estas muitas perspectivas entrem em contato umas com as outras, sejam explicitadas e possam contribuir para modificar e enriquecer os significados do que se diz e pensa sobre a Química.

Para isto não basta interagir com os alunos, permitir que eles falem ou expressem suas maneiras de pensar e suas próprias visões de mundo. Para que o aluno possa dar sentido ao que aprende e apreende, o professor precisa também contemplar essas formas de pensar no seu próprio discurso, possibilitando ao aluno comparar suas formas de pensar e falar com as do professor, colegas, livros, artigos, procedimentos etc. Isso é mais do que interagir com os alunos é dialogar com suas maneiras de ver o mundo. (MORTIMER, 2003, p. 9). Se 
simplesmente ouvimos a forma de pensar dos alunos para dizer que estão erradas ou para ignorá-las, podemos até ter e dar a impressão de que estamos dialogando, mas esse diálogo não é real, pois não contempla a forma como o aluno pensa. Para implementar essa perspectiva dialógica em sala de aula é necessário também contemplar a visão de mundo e de ciência implícita na linguagem cotidiana e nos contextos sociais e tecnológicos onde a Química se materializa. Caracterizar os discursos e os seus gêneros é fundamental para se compreender as relações dialógicas ocorridas durante esta pesquisa, verificando-se pela análise do discurso a apreensão e o aprendizado dos diversos conceitos desenvolvidos na disciplina de Química Analítica Qualitativa.

No livro “A pesquisa em Ensino de Ciências no Brasil: alguns recortes”, organizado por Roberto Nardi (2007), há um capítulo escrito por Eduardo Fleury Mortimer (et alli) intitulado "uma metodologia para caracterizar os gêneros de discursos como tipos de estratégias enunciativas nas aulas de Ciências". Este capítulo descreve uma metodologia de análise de registros em vídeo para coleta de dados em sala de aula. As diferentes classificações de gêneros, elaboradas por pesquisadores da área, deram lugar a múltiplas tipologias de acordo com os critérios de classificação instituídos, já que alguns falam de gênero de discurso, outros de gêneros de texto e outros ainda de tipos de texto. Para definir a noção, leva-se em conta ora o ancoramento social do discurso, ora sua natureza situacional, ora as regularidades composicionais do texto, ora as características formais do texto produzido. (CHARAUDEAU \& MAINGUENEAU, 2005, p. 251).

Consideram-se aqui apenas as concepções de gênero, sejam elas textuais ou do discurso, propostas por autores que compartilham uma orientação sóciodiscursiva que tem alguma raiz na herança bakhtiniana. A teoria do gênero do discurso formulada por Bakhtin centra-se no estudo das situações de produção dos enunciados ou textos e em seus aspectos sóciohistóricos. Bakhtin estabelece que a utilização da língua dá-se em forma de enunciados 
(orais e escritos; concretos e únicos), que emanam nas diferentes esferas da atividade humana. O enunciado reflete as condições específicas e as finalidades de cada uma dessas esferas, não só por seu conteúdo temático e por seu estilo verbal, mas também por usar construção composicional. Os enunciados relacionam-se, portanto, com as especificidades de uma dada esfera da comunicação. Assim, para Bakhtin, "cada esfera na qual a língua é usada desenvolve seus tipos relativamente estáveis de enunciados", denominado "gênero do discurso" (BAKHTIN, 1986, p. 60).

O gênero de discurso, desse modo, tem uma incidência decisiva sobre a interpretação dos enunciados. Não se pode interpretar um enunciado se não sabemos a qual gênero relacioná-lo. Bakhtin pontua:

Ouvindo as palavras do outro, sabemos de pronto, desde as primeiras palavras, pressentir seu gênero, adivinhar o volume (a distinção aproximativa de um todo discursivo), a estrutura composicional dada, prever seu fim, ou seja, desde o início, somos sensíveis ao todo discursivo. (BAKHTIN, 1986, p. 285).

Bakhtin estabelece uma tipologia na qual diferencia gêneros do discurso primários e secundários. Os primários são mais simples e formaram-se nas condições da comunicação discursiva imediata: diálogo cotidiano, conversa familiar etc. Já os secundários - romances, dramas, artigos científicos etc. - surgem nas condições de um convívio cultural mais complexo e relativamente muito desenvolvido e organizado (predominantemente escrito) (BAKHTIN, 1992, p. 263), por exemplo, ligados às atividades científicas, artísticas, sociopolíticas etc. Durante o processo de sua formação, esses gêneros secundaristas absorvem e transmutam os gêneros primários (simples) de todas as espécies, que se constituem em circunstâncias de uma comunicação verbal mais espontânea.

Se a teoria bakhtiniana for contraposta à teoria dos gêneros textuais, percebe-se que, na última, busca-se fazer uma descrição mais apropriadamente textual, quando se trata de 
materialidade lingüística do texto ou mais funcional/contextual, quando se trata de abordar o gênero, ao passo que a busca do analista bakhtiniano é a da significação, da acentuação valorativa e do tema, indicados pelas marcas lingüísticas, pelo estilo e pela formação composicional do texto. (ROJO, 2005).

O esforço de definir a categoria gênero seja textual ou discursivo, justifica-se levando em consideração a necessidade de caracterizar tanto estratégias enunciativas (enunciação) utilizadas pelo professor para introduzir e desenvolver os conteúdos de ensino, quanto os diferentes textos que circulam na sala de aula - livros didáticos, roteiros de atividades, provas, textos paradidáticos, tabelas etc.

A caracterização das estratégias enunciativas leva em consideração as interações verbais produzidas entre o professor e alunos e entre alunos e como as diferentes estruturas de interação utilizadas correspondem a diferentes funções do discurso. O estudo das aulas de Química Analítica Qualitativa, registradas em vídeo para esta pesquisa, poderá permitir a caracterização de um conjunto de estratégias enunciativas comuns a essa área que foram explanados pelo professor para orientar a atividade dos alunos, iniciá-los nas definições e em seguida verificar, através do discurso e da argumentação durante a prática experimental (marcha analítica para identificação de cátion e ânion) a formação dos conceitos, bem como a mobilidade do raciocínio para estruturar a tomada de decisão.

As imagens foram coletadas em câmera de vídeo sendo operada ou pelo professor ou pela técnica do laboratório, Maria do Céu Lima, numa tentativa de captar imagens que registrassem ora a interação dos alunos com os materiais e reagentes em análise, ora a dialogia discursiva travada entre os próprios pares e também entre os alunos e o professor.

Existem duas consequiências importantes para o mapeamento dos dados em vídeo de se trabalhar com o princípio bakhitiniano de que "qualquer enunciado é um elo na cadeia de comunicação verbal”. (BAKHTIN, 1986, p. 84). A primeira é que, para caracterizar a sala de 
aula e suas dinâmicas discursivas, não é suficiente analisar uma única aula, mas um certo número mínimo que configurem a rotina daquela sala de aula. Há que se pensar em uma unidade mais global de análise que forneça o contexto e confira sentido às ações dos participantes documentadas em um segmento mais curto da vida daquela classe, como uma aula. No contexto desta pesquisa, delimitou-se um conjunto de aulas em que os alunos, após uma sequiência de estudo sobre pesquisa de cátions e ânions e introdução aos protocolos analíticos para a realização de marchas analíticas, realizaram uma atividade de investigação onde deveriam qualificar qual cátion e qual ânion compõe a amostra desconhecida. As filmagens ocorreram em diversos dias para que se estabelecesse uma rotina da aula no laboratório, sendo coletadas imagens dos estudos realizados no laboratório em grupos de três a quatro alunos. As atividades foram constantemente discutidas entre os pares e com o professor, sendo estes diálogos discursivos o objeto de estudo desta pesquisa.

Esses episódios, por sua vez, podem ser decompostos em unidades menores, ou seja, em seqüências de interação, podendo essas seqüências ser pensadas e analisadas como os enunciados que caracterizam o gênero do discurso da atividade de Química Analítica Qualitativa. Ao enunciar um determinado tema, seja um fenômeno, um princípio, uma lei científica, o professor pode recorrer a diversos expedientes que envolvem desde a enunciação pura e simples, sem interlocução, até uma troca de turnos com os estudantes. O turno constitui a menor unidade de análise considerada nesta pesquisa. Normalmente cada seqüência, considerada como enunciado e, portanto, como a unidade de comunicação verbal característica do gênero de discurso da sala de aula, comporta um tema e uma intenção didática bem definidos. No entanto, como os enunciados são elos na cadeia de comunicação verbal (BAKHTIN, 1986), muitas vezes essas sequiências estão encadeadas de modo a produzir enunciados mais gerais, que configuram os grandes temas introduzidos nas aulas. 
A definição aqui de episódio é uma adaptação da definição de evento na tradição da etnografia interacional. (MORTIMER, 2002). Assim um episódio é definido como um conjunto coerente de ações e significados produzidos pelos participantes em interação, que tem início e fim claros e que pode ser facilmente discernido dos episódios precedente e subseqüente. Normalmente, esse conjunto distinto caracteriza-se, também, por uma função específica no fluxo do discurso. Marcadores de fronteiras entre os episódios incluem aspectos verbais e não verbais. As pistas contextuais, a que se refere Mortimer (2002), incluem mudanças proxêmicas (relacionadas à orientação entre os participantes) e cinestésicas (relacionadas aos gestos e movimentos corporais), mudanças de entonação, de ênfase, de tópico ao tema, de gênero, pausas etc. Essas pistas permitem a determinação precisa das fronteiras de cada episódio no fluxo do tempo. No entanto, o episódio mesmo não é definido pelas pistas contextuais que determinam suas fronteiras, mas por um conjunto de características que incluem seu tema, a fase da atividade na qual ele tem lugar, as ações dos participantes, as formas como os participantes se posicionam no espaço físico no qual ocorrem as interações, as formas pelas quais eles interagem entre si com os recursos materiais que eles usam. Para incluir todas essas características, ao transcrever os episódios filmados da aula, estabeleceu-se uma numeração seqüencial das falas, os tempos em que ocorrem os marcadores de fronteiras e os comentários contextuais que auxiliam na compreensão do gênero do discurso durante o episódio.

Cada episódio comporta uma clara intenção do professor-pesquisador, ainda que essa possa permanecer implícita e ser reinterpretada pelos alunos. Cada atividade comporta certas configurações espaços-temporais da sala de aula e das interações que aí se produzem e a execução de uma ou de um conjunto de ações.

Nesta pesquisa, pretende-se estabelecer uma análise das interações entre o aluno e outros alunos e entre o aluno e o professor na execução da atividade experimental de Química 
Analítica Qualitativa trabalhando-se com a determinação de cátions e ânions em amostras. Os padrões de discurso que prevalecem no laboratório durante a aula experimental são distintos e, como tal, constituem um gênero de discurso estável.

\subsubsection{As interações sociais do discurso e as intenções do professor}

Seguindo os princípios das teorias cognitivistas, considera-se que o Ensino de Ciências - conseqüentemente o Ensino de Química - produz um tipo de "performance pública” no plano social da sala de aula. Essa performance é dirigida pelo professor que planejou o seu "roteiro" e tem a iniciativa em "apresentar" as várias atividades que constituem sua aula. (LEACH, 2002). O trabalho de desenvolver o conhecimento específico no plano social da sala de aula é central nessa performance. Há, no entanto, outras intenções que precisam ser contempladas durante uma seqüência de ensino. Essas intenções, que são derivadas de outros aspectos da teoria sociocultural e da própria experiência docente, podem ser assim sintetizadas conforme demonstrado no quadro 1 :

QUADRO 1: Estrutura analítica para análise e planejamento de interações de ensino.

Aspectos da Análise
i. Focos do ensino
1. Intenções do professor
2. Conteúdo
ii. Abordagem
3. Abordagem comunicativa
iii. Ações
4. Padrões de interação
5. Intervenções do professor

FONTE: MORTIMER, E. F.; SCOTT, P. H. Atividades discursivas nas salas de aula de ciências: uma ferramenta sociocultural para analisar e planejar o ensino. 2002.

A transcrição (anexo 1) da explanação geral de orientação dada pelo professor/pesquisador a respeito da atividade experimental antes de ser realizada pelos alunos, demonstram suas intenções, o que produz uma performance pública, estabelece um roteiro e 
configura um plano social da sala de aula, bem como estabelece o foco do ensino, explicita o conteúdo e perfaz abordagens comunicativas importantes para as ações que se realizarão durante a prática experimental da atividade, que foi tratada pelos alunos como uma avaliação prática da disciplina.

1. P: O que eu quero que vocês façam nesta folha de avaliação: primeiro, a identificação da amostra. Eu vou entregar por grupo um frasco que está identificado com uma letra: A, B, C, D, E e F. Vou entregar por grupo uma amostra diferente. Você identifica no item 1 qual é a amostra, e depois as características físicas.

Como assim características físicas? É um sólido, um líquido, qual é a cor, qual é a granolumetria, se é cristal, se é amorfo, enfim, uma descrição em função destas características. Estas características já servem para que você comece a elaborar um roteiro de metodologia do trabalho.

Se você observar no quadro ... [referindo-se à lousa] ... eu coloquei aqui uma espécie de fluxograma geral. Então você recebeu a amostra X, você vai abrir o frasco duas vezes, você vai mexer no frasco duas vezes. Por quê? Quanto menos você mexer no frasco melhor, porque esta é a única amostra que você tem. Se você gastar toda a amostra e chegar no final sem um resultado positivo acabou a amostra. Então você irá mexer apenas duas vezes. A primeira vez, caso você opte por fazer ensaio de chama, que é um ensaio via seca... cada grupo tem uma espátula... então você com a espátula e o vidro de relógio, pega a amostra, põe no vidro de relógio, e ai você vai montar o ensaio de chama: bico de Bunsen, fio de platina, ou seja, você realiza aquele experimento normal.

2. P: Lembrando: no ensaio de chama o que é que você pesquisa? Cátions ou ânions?

3. Alunos: Cátions!

4. P: Mas eu pesquiso todos os cátions?

\section{Alunos: Não!}

6. P: Então se você for às suas anotações... quem tem ai o roteiro que tem o espectro? As cores dos espectros no ensaio de chama? Aqui! Aqui, este aqui!

7. P: Pessoal! Neste roteiro, o que você tem? As cores que cada elemento químico produz na chama e quais são os comprimentos de onda. Portanto, você tem alguns cátions que dão cor na chama. Talvez o cátion que você esteja procurando não emita cor na chama. Não tem problema nenhum. Você chegou à conclusão que o cátion da sua amostra não é nenhum desses. Portanto já os eliminou.

8. P: Então você agora passa para o procedimento que você adotou. Neste procedimento você mexe na amostra novamente, abre a amostra e 
faça então uma solução mãe. O que você vai testar? Amostra mais água. O primeiro teste que você faz: a amostra é solúvel ou não é solúvel em água? É a primeira característica. Se ela é solúvel, esta solução conduz corrente elétrica ou não conduz corrente elétrica? Conduz muito ou conduz pouco? Então se você quiser usar o condutivímetro tudo bem, pode utilizá-lo, é uma opção do grupo.

9. P: Da amostra mãe, por isso eu deixei aqui uma pipeta de Pasteur, você deixa aqui no Becker a pipeta de Pasteur, pega uma alíquota da amostra e faça o primeiro teste. Olha, vou testar a amostra com o ácido. Opa, não aconteceu nada. Quero testar a amostra com um indicador. Opa, aconteceu hidrólise. Quero testar a amostra, por exemplo, com carbonato. Opa, formou um precipitado branco. Você vai começar a juntar estas evidências para fazer a sua pesquisa de cátions e ânions.

10. P: Quando você juntar estas prováveis idéias de qual é o cátion e qual é o ânion você vai tirar uma conclusão baseada nas evidências. Portanto o seu cátion é um metal, o X de não metal, ou um metal e um não metal oxigenado. Então você tem estas evidências que te levarão a esta conclusão. Certo?

11: P: Recomendações: este deve ser um trabalho feito em equipe. Portanto, se cada um começar a fazer espontaneamente aquilo que acha que vai dar certo, por experiência própria, no final da aula vocês não vão chegar a resultado nenhum. Então a equipe deve decidir: vamos fazer tal análise. Faça a análise e discuta com o grupo. Deu certo? Não deu certo? Porque que aconteceu? Porque não aconteceu? Tome essa decisão com o grupo. A partir do momento em que vocês tomaram essa decisão passam para a próxima, porque se vocês começarem a misturar informações, daqui a pouco não sai mais nada. Está ok?

12. P: Dúvidas?

O discurso apresentado pelo professor-pesquisador contém diversos elementos importantes onde é possível estabelecer um paralelo entre suas intenções e o foco de sua abordagem, a qual orienta os alunos na realização dos procedimentos experimentais investigados. Fica explícita a proposta da atividade (foco do ensino) que se estabelece por uma abordagem comunicativa que provoca nos alunos uma mobilidade do pensamento pela interação com os conceitos e com o conteúdo que são apresentados pela linguagem numa forma discursiva. Então já se estabelece um raciocinar para que se inicie um planejamento das ações a partir do problema proposto (determinar qual cátion e qual ânion compõe a amostra), havendo então uma caracterização deste problema pelos ideais explicativos e as capacidades 
correntes (TOULMIN, 2004), como já discutido no início do capítulo 2. Emergem os conceitos já estruturados e a interação destes num nível fenomenológico com a amostra real. Tudo isto numa dimensão dialógica, pois o professor insiste que as ações planejadas e realizadas sejam discutidas com os pares.

O quadro 2 auxilia na compreensão das intenções do professor ao estruturar este discurso inicial.

QUADRO 2: Intenções do professor no plano social da sala de aula.

\begin{tabular}{ll}
\hline Intenções do professor & Foco \\
\hline Criando um problema & $\begin{array}{l}\text { Engajar os estudantes, intelectual e } \\
\text { emocionalmente, no desenvolvimento inicial da } \\
\text { atividade científica. }\end{array}$ \\
\hline Explorando a visão dos estudantes & $\begin{array}{l}\text { Elicitar e explorar as visões e entendimentos dos } \\
\text { estudantes sobre idéias e fenômenos específicos. }\end{array}$ \\
\hline $\begin{array}{l}\text { Introduzindo e desenvolvendo o } \\
\text { conhecimento específico }\end{array}$ & $\begin{array}{l}\text { Disponibilizar as idéias científicas (incluindo } \\
\text { temas conceituais, epistemológicos, tecnológicos } \\
\text { e ambientais) no plano social da sala de aula. }\end{array}$ \\
\hline $\begin{array}{l}\text { Guiando os estudantes no trabalho com as } \\
\text { idéias científicas, e dando suporte ao } \\
\text { processo de internalização }\end{array}$ & $\begin{array}{l}\text { Dar oportunidades aos estudantes de falar e } \\
\text { pensar com as novas idéias científicas, em } \\
\text { pequenos grupos e por meio de atividades com } \\
\text { toda a classe. Ao mesmo tempo, dar suporte aos } \\
\text { estudantes para produzirem significados } \\
\text { individuais, internalizando essas idéias. }\end{array}$ \\
\hline
\end{tabular}

Guiando os estudantes na aplicação das idéias científicas e na expansão de seu uso, transferindo progressivamente para eles o controle e responsabilidade por esse uso
Dar suporte aos estudantes para aplicar as idéias científicas ensinadas a uma variedade de contextos e transferir aos estudantes controle e responsabilidade (WOOD, et al., 1976) pelo uso dessas idéias.

Prover comentários sobre o desenrolar do conhecimento específico, de modo a ajudar os estudantes a seguir seu desenvolvimento e a entender suas relações com o currículo de ciências como um todo.

FONTE: MORTIMER, E. F.; SCOTT, P. H. Atividades discursivas nas salas de aula de ciências: uma ferramenta sociocultural para analisar e planejar o ensino. 2002. 
Não somente o discurso do professor tem uma intenção no plano social da aula, mas todos aqueles que serão estabelecidos e compostos a medida que há uma interação dialógica entre os próprios alunos na intenção de estabelecer um aproximações entre os conceitos teóricos e os empíricos verificados pela realização da práxis experimental.

\subsubsection{Pensamento e linguagem}

O desenvolvimento da linguagem passa por uma fase pré-intelectual, em que é utilizada somente como meio de intercâmbio. Este comportamento também é observado tanto na análise filogênese, quanto na ontogênese ${ }^{(7)}$. Num determinado momento da evolução humana, pensamento e linguagem passam a se relacionar, sendo que a linguagem assume um caráter generalizante passando a funcionar como instrumento de pensamento. A ação, conseqüentemente o trabalho, é uma atividade que exige a utilização de instrumentos materiais para a transformação da natureza e, por outro lado, o planejamento da ação de como utilizá-los, fazendo-se necessário uma ação coletiva e, portanto, a comunicação social.

Esta relação entre pensamento e linguagem tem implicações importantes para as pesquisas sobre Ensino de Ciências, visto que além de seu papel mediador da comunicação em sala de aula, a linguagem muitas vezes consiste no próprio objeto de estudo dos alunos. (CAPECCHI, 2004). Além disso, como será abordado na análise da transcrição das aulas de Química Analítica Qualitativa (capítulo 3), diferentes linguagens podem ser reconhecidas, empregadas tanto como recursos semióticos, quanto como parte do conteúdo a ser trabalhado.

\footnotetext{
${ }^{(7)}$ Em suas investigações sobre a espécie humana, Vygotsky $(1934 ; 2001)$ encontrou o que denominou fase préverbal do desenvolvimento do pensamento e fase pré-intelectual do desenvolvimento da linguagem. Segundo Oliveira (1999) o primeiro caso refere-se ao emprego de instrumentos materiais na mediação entre o sujeito e o ambiente, numa espécie de "inteligência prática", que habilita o primeiro a resolver problemas e modificar o segundo. Este tipo de função pode ser observado tanto ao longo da evolução da espécie humana (filogênese), aparecendo também no comportamento de animais, quanto no desenvolvimento do ser humano (ontogênese), aparecendo na utilização de materiais pelas crianças como meio de alcançar objetos distantes, por exemplo.
} 
Driver e Newton (1997) abordam este tema:

\begin{abstract}
Uma vez que a Ciência envolve um processo de construção social de conhecimento, isto significa que os termos, os modelos e modos de ver o mundo aprovado pelos cientistas são produtos humanos - eles não são percebidos diretamente da natureza. Dar aos aprendizes acesso a estes "modos de ver", portanto, requer mais do que lhes dar acesso a fenômenos. Significa induzir aprendizes no modo particular de representar o mundo usado pelos cientistas e socializá-los para adotarem as ferramentas culturais daquela cultura. (DRIVER \& NEWTON, 1997, p. 13).
\end{abstract}

Os autores sugerem que maior atenção seja dada ao trabalho com a linguagem em sala de aula, considerando seu papel estruturante na construção do conhecimento científico. Para compreender o mundo simbólico da Ciência é necessário que o aprendiz entre em contato não somente com produtos acabados da mesma, mas também com processos de construção de significados, baseados no emprego de ferramentas provenientes da cultura científica, dentre elas a linguagem social da Ciência. (CAPECCHI, 2004).

Para que o estudo de teorias científicas faça sentido para os alunos, é preciso que estes compreendam a que fim tais teorias são propostas. Um conjunto de conceitos, que na maioria das vezes opõem-se ao senso comum, aparentemente não apresenta nenhuma utilidade para um aluno que não tem acesso à forma como é elaborado e aos princípios que regem tal elaboração. A afirmação de Lemke (2003) traduzida a seguir (por Capecchi) expressa bem esta questão:

\begin{abstract}
A Ciência não pode ser igualada a seus produtos: o que a Ciência diz sobre o mundo não é a Ciência em si. A Ciência em si é uma atividade humana que produz estas declarações e teorias, e aprender Ciência não é aprender o que a última geração de cientistas pensou sobre o mundo: é aprender como cada nova geração de cientistas refaz nossa visão do mundo. (LEMKE, 2003, p.3).
\end{abstract}

Para que este processo ocorra, os estudantes precisam ter oportunidades de expor suas idéias em sala de aula, num ambiente encorajador, adquirindo segurança no envolvimento com as práticas científicas. É fundamental a criação de espaços para a fala dos alunos, seja ela 
oral, através da argumentação com os pares e com o professor, ou escrita, mediante a apresentação de relatórios e redações. Através da fala, além de tomar consciência de suas próprias idéias, estes também têm a oportunidade de ensaiar o uso de uma linguagem adequada ao tratamento científico da natureza.

É preciso considerar, porém, que outras linguagens estão envolvidas na construção do conhecimento científico:

A Ciência não fala do mundo somente na linguagem de palavras e, em muitos casos, ela simplesmente não pode fazê-lo. A linguagem natural da Ciência é uma integração sinérgica de palavras, figuras, gráficos, mapas, equações, tabelas, esquemas e outras formas de expressão visual e matemática. (LEMKE, 2003, p.6).

Esta afirmação reforça mais uma vez a necessidade de um contato mais próximo dos estudantes com as ferramentas da Química numa atividade desenvolvida em laboratório - que tem função didática de sala de aula no que tange a construção de conhecimento e não meramente um espaço para reprodução de idéias e procedimentos confirmatórios dos conceitos teóricos - pois coloca os estudantes numa íntima interação com os fenômenos da transformação da matéria, havendo então a possibilidade de controlá-los, processá-los e principalmente de apreciá-los verificando a mútua cooperação que há entre as diversas linguagens da Ciência, dos conhecimentos produzidos pelas gerações passadas e dos conhecimentos adquiridos in locuo durante a prática experimental na formação do atual conhecimento e, principalmente, na capacidade da construção de explicações e da argumentação a partir dos conceitos estruturados cognitivamente. 


\subsection{0 conteúdo da argumentação em sala de aula e as abordagens comunicativas}

Nas salas de aula de Química Analítica Qualitativa, as interações entre o professor e os estudantes podem ser relacionadas a uma ampla variedade de conteúdos incluindo, por exemplo, o conhecimento específico, aspectos procedimentais, questões organizacionais, de disciplina e de manejo de informações. Cada um desses aspectos é importante para a formação do conhecimento e do conceito a ser aprendido; e nesta pesquisa verifica-se através do discurso e da categorização dele a reversibilidade do pensamento e a capacidade do aluno de estabelecer uma antecipação da ação e previsão para a obtenção do resultado da experimentação, bem como a capacidade de articular estes conceitos na resolução de uma atividade teórica (questionário) realizada após a prática experimental.

Assim como nos trabalhos de Mortimer e Scott (2000), a análise do conteúdo do discurso da aula experimental, em termos de categorias, pode ser considerada como característica fundamental da linguagem social (BAKHTIN, 1986) das ciências escolar, tomando por base a distinção entre descrição, explicação e generalização.

A descrição envolve enunciados que se referem a um sistema, objeto ou fenômeno, em termos de seus constituintes ou dos deslocamentos espaço-temporais desses constituintes. Já a explicação envolve importar algum modelo teórico ou mecanismo para se referir a um fenômeno ou sistema específicos. E por fim a generalização envolve elaborar descrições ou explicações que são independentes de um contexto específico.

Uma distinção adicional considerada importante relaciona-se ao fato de que descrições, explicações e generalizações podem ser caracterizadas como empíricas ou teóricas. Assim, descrições e explicações que se utilizam referentes (constituintes ou propriedades de um sistema ou objeto) diretamente observáveis são caracterizadas como empíricas. Já as descrições e explicações que utilizam referentes não diretamente observáveis, 
mas que são criados por meio do discurso teórico das ciências, como no caso de modelos para a matéria, são caracterizadas como teóricas. (MORTIMER, 2000).

A atividade realizada então na disciplina de Química Analítica Qualitativa proporciona aos estudantes uma ideal situação para que a capacidade de generalização seja constituída, pois, durante o experimento, ocorre uma generalização empírica e imediatamente após a ocorrência do fenômeno químico inicia-se uma generalização teórica, o que culmina na resolução do problema ou o levará a uma mobilidade retroativa e antecipatória para a realização de uma nova etapa na atividade buscando esta resolução.

Quando um professor interage com os estudantes numa sala de aula ou numa atividade experimental em laboratório, a natureza das intervenções pode ser caracterizada em termos de dois extremos. No primeiro deles, o professor considera o que o estudante tem a dizer do ponto de vista do próprio estudante; mais de uma "voz" é considerada e há uma interanimação de idéias. Este primeiro tipo de interação constitui uma abordagem comunicativa dialógica. No segundo extremo, o professor considera o que o estudante tem a dizer apenas do ponto de vista do discurso científico escolar que está sendo construído. Este segundo tipo de interação constitui uma abordagem comunicativa de autoridade, na qual apenas uma "voz" é ouvida e não há interanimação de idéias.

Na prática, qualquer interação provavelmente contém aspectos de ambas as funções, dialógica e de autoridade. Uma característica importante da distinção entre as abordagens dialógicas e de autoridade na comunicação em sala de aula, é que uma sequiência discursiva pode ser identificada como dialógica ou de autoridade independentemente de ter sido enunciada por um único indivíduo ou interativamente. $\mathrm{O}$ que torna o discurso funcionalmente dialógico é o fato de que ele expressa mais de um ponto de vista - mais de uma "voz" é ouvida e considerada - e não que ele seja produzido por um grupo de pessoas ou por um indivíduo solitário. Esse último aspecto está relacionado à segunda dimensão da abordagem 
comunicativa, que distingue entre o discurso interativo, aquele que ocorre com a participação de mais de uma pessoa, e o discurso não-interativo, que ocorre com a participação de uma única pessoa. Essas duas dimensões podem ser combinadas para gerar quatro classes de abordagem comunicativa, como mostrado no quadro 3 .

QUADRO 3: Duas dimensões e quatro classes de abordagem comunicativa.

INTERATIVO NÃO-INTERATIVO

DIALÓGICO Interativo / Dialógico Não-interativo / Dialógico

DE AUTORIDADE Interativo / de autoridade Não-interativo / de autoridade

FONTE: MORTIMER, E. F.; SCOTT, P. H. Atividades discursivas nas salas de aula de ciências: uma ferramenta sociocultural para analisar e planejar o ensino. 2002.

Cada uma dessas quatro classes está relacionada ao papel do professor ao conduzir o discurso da classe, elas são igualmente aplicáveis para caracterizar a interações que ocorrem apenas entre estudantes, por exemplo, em pequenos grupos. Em termos gerais, as classes de abordagem comunicativa podem ser definidas conforme a quadro 4. 
QUADRO 4: Duas dimensões e quatro classes de abordagem comunicativa.

\begin{tabular}{ll}
\hline & Há a participação de mais de uma pessoa e são \\
& considerados diferentes pontos de vista na interação. \\
Interativo / Dialógico & Geralmente professor e alunos exploram diferentes idéias, \\
& fazem perguntas autênticas e oferecem, escutam e \\
discutem diferentes pontos de vista.
\end{tabular}

Há a participação de mais de uma pessoa, mas somente um ponto de vista é considerado na interação,

Interativo / de autoridade normalmente $\mathrm{o}$ da ciência escolar. $\mathrm{O}$ professor, geralmente, conduz os estudantes mediante uma sequiência de perguntas e respostas com o objetivo de chegar a um determinado ponto de vista.

Somente uma pessoa está envolvida na ação Não-interativo / Dialógico comunicativa e mais de um ponto de vista é considerado. Geralmente o professor sintetiza e revê diferentes pontos de vista, destacando similaridades e diferenças.

Somente uma pessoa produz enunciados e somente um

Não-interativo / de autoridade ponto de vista é considerado na ação comunicativa. Normalmente o professor apresenta esse único ponto de vista, o da ciência escolar.

FONTE: AMARAL, E. M. R.; MORTIMER, E. F. Uma metodologia para análise da dinâmica entre zonas de um perfil conceitual no discurso da sala de aula. In: SANTOS, F. M. T. A pesquisa em Ensino de Ciências no Brasil e suas metodologias. Ijuí: Ed. Unijuí, 2006.

Este aspecto da análise especifica padrões de interação que emergem na medida em que professor e alunos alternam turnos de fala na sala de aula. O mais comum são as tríades IR-A (Iniciação do professor, Resposta do aluno, Avaliação do professor), mas outros padrões também podem ser observados. Por exemplo, em algumas interações o professor apenas sustenta a elaboração de um enunciado pelo aluno, por meio de intervenções curtas que muitas vezes repetem parte do que o aluno acabou de falar, ou fornecem um feedback para que o estudante elabore um pouco essa fala. Essas interações geram cadeias de turnos não triádicas do tipo I-R-P-R-P... ou I-R-F-R-F... onde P significa uma ação discursiva de permitir o prosseguimento da fala do aluno e $\mathrm{F}$ um feedback para que o aluno elabore um pouco mais sua fala. 
O trabalho apresentado por Capecchi e Carvalho (2001) descreve também um estudo a respeito da argumentação dos alunos. O trabalho por elas realizado foi tanto do ponto de vista estrutural, através da identificação de componentes presentes nos argumentos isolados, quanto do ponto de vista da interação entre os locutores, observando a presença de diferentes idéias e a busca de sínteses na argumentação como um todo.

O incentivo à participação dos alunos em discussões sobre os temas a serem estudados em aula e os trabalhos em grupos envolve dimensões importantes na formação geral dos estudantes, tais como, o aprendizado de uma convivência cooperativa com os colegas, o respeito às diferentes formas de pensar, o cuidado na avaliação de uma afirmação e a autoconfiança para a defesa de pontos de vista.

No contexto de Ensino de Ciências, estas trocas de idéias entre os alunos e a elaboração de explicações coletivas possibilitam o contato com o aspecto importante para a formação de uma visão da Ciência como uma construção de uma comunidade, cujas teorias estão em constante processo de avaliação. Os alunos devem conhecer esta faceta do conhecimento científico, identificando-o como o resultado de interações entre idéias diferentes, como réplica a outros enunciados e também sujeito a novas réplicas. Geralmente a visão de Ciência que é veiculada na escola é aquela de um conhecimento estático, através de apresentação de teorias acabadas, inquestionáveis. (CARVALHO, 2006).

Através da argumentação os estudantes entram em contato com algumas habilidades importantes dentro do processo de construção do conhecimento científico, tais como, reconhecimento entre afirmações contraditórias, identificação de evidências e confronto de evidências com teorias. A argumentação também pode ser empregada como uma forma de aproximação entre os pensamentos científicos e cotidianos, já que também é muito presente no segundo. (KUHN, 1993). 
Quando se refere ao estudo da argumentação nas aulas de Ciências, o interesse está em observar as enunciações elaboradas pelos alunos durante discussões visando à construção de explicações coletivas para determinados fenômenos. Desta forma, a interpretação de Capecchi e Carvalho (2001) era bastante semelhante à definição apresentada por Krummheuer (1995) e Driver (1999), em que este é considerado como o esclarecimento intencional de um raciocínio durante ou após sua elaboração.

As atividades propostas por Carvalho et alii. (1998) são especialmente elaboradas para que os alunos tenham a oportunidade de resolver problemas de Ciência e tomar consciência das variáveis envolvidas nesta solução, característica fundamental nas práticas de Química Analítica Qualitativa. Para que tal objetivo seja atingido, as atividades contam com algumas etapas. Inicialmente o professor propõe um problema experimental que deve ser resolvido pelos alunos em pequenos grupos, de três a cinco estudantes. É essencial que os experimentos e o fenômeno envolvido possam ser controlados pelos estudantes, produzindo-os quantas vezes julgarem necessário para sua compreensão e também variando suas ações sobre os objetos envolvidos. Foi baseada nesta concepção de investigação que se realizou a experimentação realizada nesta pesquisa, onde os alunos, ao realizarem as marchas analíticas para a determinação do cátion e ânion que compunha a amostra, podiam eleger a seqüência de análise, além de repeti-las quantas vezes julgassem necessárias até que houvesse total compreensão (ou não) do fenômeno ocorrido.

Durante e após a resolução de problemas via experimentação, é realizada uma discussão entre os pares e com o professor. Este diálogo tem como objetivo a narração dos fatos observados. Desta forma há uma interação dialógica que explicita o domínio ou não do conceito e a reversibilidade do pensamento e a mobilidade antecipatória. (PIAGET, 1959). Desta forma, os estudantes têm a oportunidade de tomar consciência de suas ações, refletindo 
sobre as mesmas, chegando a construir explicações causais para o fenômeno estudado. (CARVALHO, 2000).

$\mathrm{Na}$ prática realizada experimentalmente os alunos estabeleceram um padrão discursivo, ou seja, o professor inicia o diálogo (I), o aluno responde (R) e outro aluno ou o próprio professor dá um feedback (F). Quando o professor faz perguntas ao aluno exigindo fidelidade a significados já compartilhados pela classe, ou seja, perguntas com respostas bem definidas, este padrão é denominado avaliativo. A função de transmissão da argumentação implica na existência de um código comum entre transmissor e receptor, qualquer diferença de interpretação pode resultar numa falha no sistema de comunicação.

Embora o padrão discursivo predominante em aula tenha seja o eliciativo, nos momentos em que alguns conceitos já estudados precisavam ser retomados, e também a necessidade de sistematização das idéias levantadas, o padrão avaliativo prevaleceu. Este fato vai ao encontro das observações de Mortimer e Machado (1997), que apontam a alternância de padrões I-R-F (Iniciação do professor, Resposta do aluno, Feedback) em sala de aula de acordo com os objetivos da discussão. 


\section{CAPÍTULO 3}

\section{Estudo da argumentação e da estruturação do pensamento reversível por meio das} atividades didáticas nas aulas de química analítica qualitativa

Os dados desta pesquisa foram obtidos através da gravação em vídeo de uma prática experimental na disciplina de Química Analítica Qualitativa com os alunos do curso técnico em Química do Colégio e Faculdade Anchieta, da cidade de São Bernardo do Campo, região do ABC Paulista de São Paulo. No currículo do curso, a disciplina de Química Analítica Qualitativa tem carga horária de sete aulas semanais, perfazendo um total de 350 minutos, distribuídas na seqüência de duas, duas, uma e duas aulas ao longo dos dias da semana, tendo cada aula 50 minutos.

Sendo a proposta deste capítulo o estudo da argumentação e da estruturação do pensamento reversível, para a organização desta ação e a compreensão das ações ocorridas através dos referenciais teóricos, a transcrição das aulas registradas em vídeo foi organizada em episódios que consiste numa fração de argumentos do total do procedimento experimental (anexo 1), conforme já discutido pelos referenciais teóricos expostos no item 2.2 e seqüentes. À medida que o estudo deste capítulo é aprofundado, recortes destes episódios são apresentados ao longo do texto para estabelecer uma articulação que auxilie no estudo das hipóteses desta pesquisa, sendo as falas numeradas seqüencialmente, o proponente do argumento nomeado e o professor/pesquisador identificado pela letra "P".

\subsection{Plano de aula da disciplina}

O plano de aula da disciplina inicia-se com uma discussão a respeito do reconhecimento de fenômenos físicos e químicos através de uma prática experimental e, que 
se promove a queima de materiais, mistura de substâncias, fusão e ebulição da água, fusão e posterior solidificação de outros materiais, ataque de metais e minerais com ácidos. Não há a intenção de levar o aluno a estabelecer uma mera classificação dos fenômenos como químicos e físicos, visto que a fronteira que os determina não é muito bem delineada e, a medida que a discussão se aprofunda, argumentar sobre a natureza do fenômeno e defini-lo puramente como químico ou físico não é algo relevante. Estas práticas têm em vista a importância da construção de um modelo que possibilite ao estudante articular os fenômenos com uma teorização relativamente simples, mas útil. Interessam a possibilidade de elaboração de um modelo de partícula para explicar o estado físico e as transformações dos materiais, particularmente as mudanças de estado e dissoluções. A importância de ensinar um modelo de partícula é que ele possui a estrutura básica comum a todos os modelos mais sofisticados da Química, mas pode ser elaborado a partir de idéias intuitivas dos alunos. Esta atividade permite então evidenciar que entre as partículas da matéria há um movimento intrínseco; que as partículas são de dimensões infinitamente pequenas; as partículas não possuem todas as propriedades que podemos atribuir às substâncias, ou seja, as partículas não se dilatam, não se fundem etc.

Várias outras práticas são realizadas como separação de misturas, determinação da pureza das substâncias, determinação de propriedades físicas, entre outras, com o objetivo de ampliar a relação dos alunos com os processos de transformação da matéria e sua capacidade intelectual de aproximação do nível fenomenológico para um nível do pensamento teórico. Esta seqüência didática inicia então os estudos das reações químicas com uma preocupação em estabelecer uma relação da linguagem semiótica com o fenômeno que se observa, como o descrito na figura 7 que representa a reação entre uma solução contendo nitrato de chumbo $\left(\mathrm{PbNO}_{3}\right)$ e iodeto de potássio (KI). Após a mistura dos reagentes forma-se um produto amarelo e insolúvel em água, o iodeto de chumbo $\left(\mathrm{PbI}_{2}\right)$. Pela observação deste fenômeno e 
de outros realizados experimentalmente, o aluno é levado a formar um conjunto de evidências que o auxilie na estruturação do conceito de reação química e seja iniciado no estudo dos equilíbrios químicos.
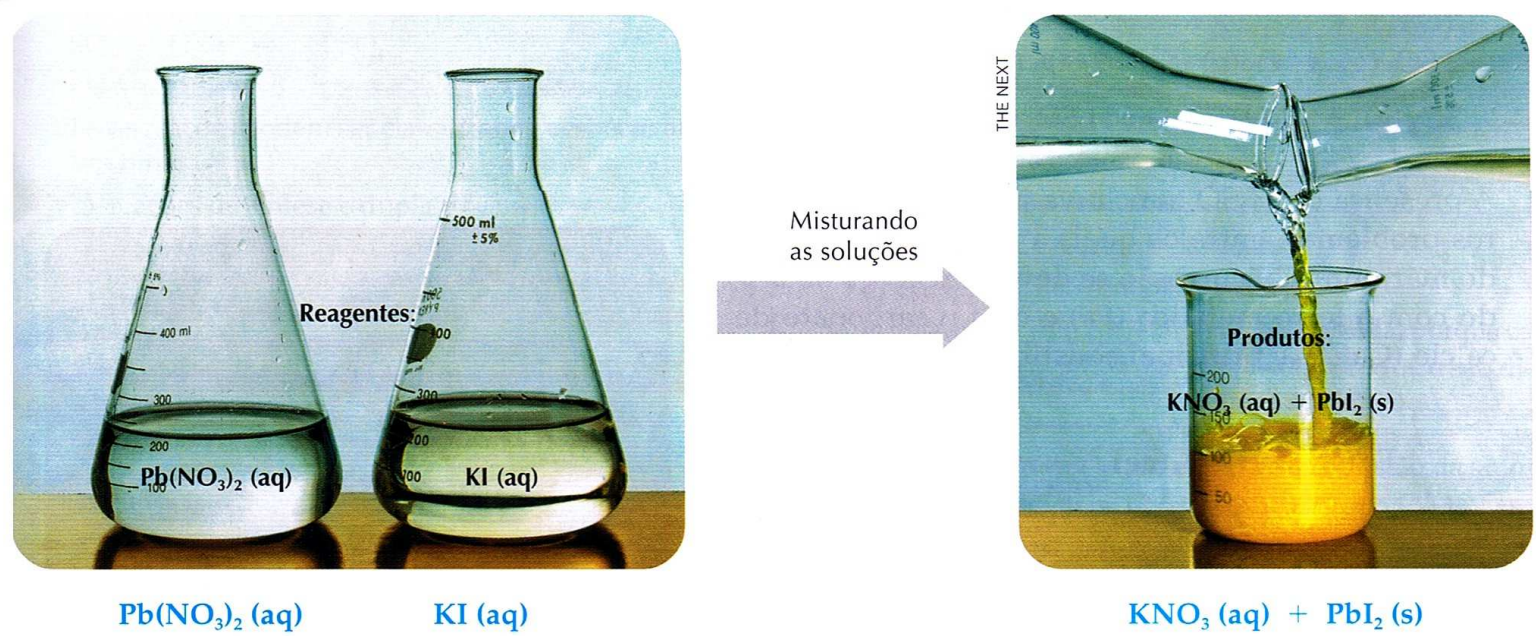

Figura 7: Exemplos de reaçães de precipitação de nitrato de chumbo e iodeto de potássio, obtendo-se iodeto de chumbo (sólido) e nitrato de potássio (em solução aquosa). (PERUZZO, 2006, p. 439).

Há ainda que relembrar, como descrito no capítulo 2, que, paralelamente e anteriormente, os alunos já cursaram ou cursam as disciplinas de Química Geral, Química Inorgânica, e Química Orgânica, desta forma a discussão da disciplina é construída com uma aproximação entre os conceitos teóricos e as ações práticas que se perfazem nas práticas de Química Analítica Qualitativa. É neste contexto então que se propõe o estudo de Equilíbrios Químicos já preparando um campo de conhecimentos conceituais para iniciar a principal proposta da disciplina - e desta pesquisa - que é a marcha analítica para pesquisa de cátions e ânions.

Em geral, as abordagens a respeito de Equilíbrios Químicos enfatizam aspectos quantitativos (matemáticos) relacionados ao conceito, em detrimento de uma abordagem qualitativa. Ao final do estudo, muitos alunos são capazes de calcular constantes de equilíbrio a partir das concentrações de reagentes ou de produtos utilizando os valores de $\mathrm{K}_{\mathrm{ps}}$ descritos 
na tabela 2. Todavia, a intenção didática e pedagógica na estruturação do estudo deste conteúdo foi estabelecer uma compreensão a respeito do que ocorre em um sistema em equilíbrio no nível atômico-molecular, pois a mera execução mecânica de cálculos, sem o estabelecimento de relações com os aspectos observáveis e mensuráveis, bem como aqueles aspectos relacionados aos modelos para a constituição das substâncias, dificulta e, em alguns casos, pode impossibilitar a compreensão dos aspectos fundamentais do conhecimento sobre o estado de equilíbrio químico.

Por se tratar de uma disciplina regular do curso, faz parte do programa e planejamento do curso a realização de uma avaliação bimestral que foi realizada após a sequiência de estudos teóricos e experimentais em laboratório. No Colégio e Faculdade Anchieta, a avaliação bimestral é concebida numa proposta chamada de Avaliação Interdisciplinar que é formada por trinta questões de múltipla escolha, contendo perguntas de todas as disciplinas cursadas pelo aluno ao longo do bimestre. Deste conjunto de questões, sete eram referentes à disciplina de Química Analítica Qualitativa e foram estruturadas para abordarem questões conceituais a respeito dos estudos realizados durante o período, o que levou o aluno a interagir com os conceitos de forma teórica e individual, diferentemente da prática empírica realizada no laboratório onde há uma interação com o conceito num nível fenomenológico e com mediação dos pares, sejam outros alunos ou o próprio professor.

\subsection{Análise da argumentação na atividade experimental}

Com esta proposta e seqüência didática, deseja-se iniciar um processo de aprendizagem na disciplina que pode ser descrita como uma mudança do perfil conceitual do estudante, cujo novo perfil inclui também, mas não exclusivamente, novas idéias científicas. (MORTIMER, 2003, p. 30). As diferentes formas de pensar e falar sobre um mesmo conceito 
e usá-lo de diferentes maneiras, em diferentes contextos é chamado por Mortimer de zonas de perfil conceitual. Segundo o autor, à medida que se percorre esse perfil conceitual, qualquer conceito vai se tornando mais complexo e também mais racional. Além disso, a parte "realista" desse perfil pode ser relacionada às concepções cotidianas que os estudantes possuem, muitas vezes independentemente da formação escolar.

\begin{abstract}
Na química, como na vida em geral, nem sempre os fenômenos mostram a essência. É possível se dizer que na maioria das vezes não mostram. E no cotidiano as pessoas lidam com as coisas num nível fenomenológico, até porque seria impossível viver adotando constantemente uma atitude questionadora e argüidora. Há registros de que o homem produz bebidas alcoólicas há vários milhares de anos, muito antes de se questionar a natureza da fermentação alcoólica; da mesma forma não pensamos na desnaturação das proteínas quando fazemos uma omelete. Pensamos no conhecimento químico, e considerando que processos químicos acontecem a todo momento em nossas vidas, é possível afirmar que aprendemos química constantemente, mas num nível fenomenológico de conhecimento: o conhecimento empírico, que desenvolve um vasto campo de capacidades intelectuais, mas expressa a existência das coisas nas categorias de quantidade, qualidade, propriedade, medida. O conhecimento empírico conduz o pensamento à cognição da identidade, da essência, da causalidade. Isto só é feito pelo pensamento teórico. (ECHEVERRIA, A. Como os estudantes concebem a formação de soluções. Química Nova na Escola, n. 3, 1996).
\end{abstract}

Uma mesma pessoa pode ter várias formas de pensar e falar sobre um mesmo conceito, e usá-las em diferentes contextos. Essas diferentes formas vão desde aquelas muito ligadas à vida cotidiana, impregnadas de realismo e de percepção sensorial imediata, até muito sofisticadas, que expressam a realidade em termos puramente matemáticos e científicos. Entre esses extremos há várias formas mais racionais de ver o mundo, em que a realidade imediata pode ser problematizada por meio de experiências empíricas ou deduzidas de relações matemáticas entre diferentes variáveis. Essas diferentes formas de ver o mundo podem ser pensadas como diferentes zonas num perfil conceitual.

A transcrição da argumentação do episódio 5 entre o aluno Flávio e o professor descreve a dificuldade conceitual de compreensão do fenômeno químico pela observação das reações químicas estabelecendo uma relação empírica e teórica expressa pela argumentação 
que articula o conceito em dois diferente níveis: o empírico e o teórico, como já aprofundados no item 2.3 e agora relacionados numa interação dialógica ente o aluno e o professor.

30. Flávio: Professor? Sabe o que eu não consigo colocar na cabeça?

31. P: O quê?

32. Flávio: Como eu consigo, na explicação teórica, estava batendo tudo, acho que eu até falei demais, mas aqui eu não consigo intercalar as coisas... ligar as informações [pausa] para chegar numa conclusão. Acho que tem muita coisa aqui que dá para eu chegar a algum lugar.

33. P: Dá. Você precisa juntar quais foram as evidências ocorridas... [o aluno interrompe o professor]...

34. Flávio: É esse juntar que eu não consigo...

35. P: [o P continua a fala] ... para poder justificar. Olha, vamos juntar coisas aqui.

36. P: Olha: no ensaio de chama, deu amarelo, que é o sódio.

37. Flávio: Isso.

38. P: Então você tem uma possibilidade. Não dá para bater o martelo e dizer que é o sódio.

39. Flávio: Isso.

40. P: Agora, no ânion. É alguma coisa de sódio. Agora, vamos ver quais foram as evidências daquilo que você já fez.

O P faz a leitura das anotações do aluno e o questiona.

41. P: Ao colocar o $\mathrm{HCl}$ formou um precipitado branco? É isso?

42. Flávio: Sim, formou.

43. P: Então significa que se você adicionou $\mathrm{HCl}$, significa que o cloreto reagiu com o sódio?!

44. Flávio: Então para eu me certificar que... [pausa]... mas aqui...

45. P: Mas ai é que está. Agora veja: quando você colocou aqui, olha, $\mathrm{HCl}$, portanto, o que veio daqui? Veio o cloreto. Cloreto é o reagente de grupo. Cloreto não reage com o sódio!

46. Flávio: Não reage?!

47. P: Não reage!

48. P: Então, ao adicionar o cloreto, formou um precipitado branco. Agora, vamos continuar, o que mais você colocou?

49. P: Cloreto formou um precipitado branco. O iodeto: quando você colocou o iodeto formou um precipitado branco também?

50. Flávio: ... [silêncio] ...

51. P: Iodeto não reage com o sódio.

52. Flávio: Não reage!

53. P: Não reage. Ai você colocou aqui de novo... cloreto... [o aluno interrompe o $P$ ]... 
54. Flávio: Como que fala quando precipita? O que precipita não é o que fica no fundo?

55. P: Isso!

56. Flávio: E aqui, a amostra ficou branca, ficou tipo leite.

57. P: Então a sua amostra não dissolveu na água?

58. Flávio: Não!

59. P: Então sua amostra é insolúvel. Por isso existe sempre um precipitado antes mesmo de você adicionar o reagente.

Ao analisar a argumentação do aluno Flávio verifica-se inicialmente que ele julga-se capaz de compreender os conceitos teóricos (32), mas ao realizar a prática experimental não consegue estabelecer uma relação com os seus conhecimentos e os fenômenos observados, não estabelecendo, portanto uma explicação pela dificuldade de raciocinar e aproximar estas duas realidades conceituais. Ele reconhece esta dificuldade usando a expressão "colocar na cabeça" (30). Sua expressão, "é esse juntar que eu não consigo" (34), revela um reconhecido obstáculo epistemológico, sobre o qual afirma Bachelard (1938; 1996), tratar-se de um pensamento pré-científico que tornar-se-á científico pela interação com o fenômeno, com o aprendizado nos laboratórios e a decodificação dos livros científicos, impondo então uma visão diferente da inicial.

O aluno, juntamente com o grupo, identificou o sódio como cátion e, ao adicionar $\mathrm{HCl}$ descreve a formação de um precipitado, entretanto não compreende que entre $\mathrm{o} \mathrm{Na}^{+} \mathrm{e} \mathrm{o} \mathrm{Cl}^{-}$ não ocorre uma reação química que forme um produto insolúvel (41 a 49). A análise da argumentação final entre o aluno e o professor nos faz perceber que o aluno não domina o conceito fundamental de solubilidade sendo que esta característica é um importante conceito para o início da marcha analítica, como discutido no item 1.2 a respeito da práxis experimental. O aluno (e também o grupo) não foi capaz de reconhecer que a substância não é solúvel em água e isso nos leva a concluir que adicionaram os reagentes sem estabelecer um pensamento antecipatório que estrutura o planejamento da ação analítica. 
Entretanto, à medida que o aluno toma consciência de seu perfil conceitual, mesmo que inicialmente esse perfil contenha apenas umas poucas formas diferenciadas de ver e construir o fenômeno discursivamente, ele estará apto a perceber a dinâmica do conhecimento e admitir uma diferenciação maior desse perfil no futuro, com a aprendizagem de conceitos mais sofisticados.

O início da atividade analítica requer o domínio de conceitos de quantidade e conservação de massa, condições mentais estabelecidas pela estruturação do raciocínio no período das operações concretas. Como a análise qualitativa deve ser conduzida numa escala macroanalítica a semimicroanalítica, com a quantidade de amostra variando de 1,0 a 0,05 g, ao recebê-la os alunos devem perceber visualmente que a quantidade de amostra é muito além da necessária, capacidade de raciocínio estabelecida pela operação concreta do raciocínio, mas a grande maioria dos alunos não é capaz de estabelecer esta relação, conforme a seqüência de argumentos 13 a 19 do episódio 2.

13. P: Vocês já pegaram a amostra?

14. Ronaldo: Não!

15. P: Então toma. Pegue esta.

16. Rafael: Agora sim!

17. Débora: Mas só isto professor?

18. Ronaldo: Não é muito não? ... [fala num tom sarcástico $]. .$.

19. P: Volta nas anotações de aula e veja qual é o conceito de análise ... [pausa] ... Macroanálise, microanálise e ultramicroanálise. A macroanálise é feita com meio a um grama de amostra. Então tem amostra mais do que suficiente ai.

No item 2.1.1 discutimos as idéias de Rappaport (1981) e Oliveira (2001) a respeito dos pressupostos da teoria de Piaget onde, tais adultos estariam, portanto, no estágio operatório-concreto e não teriam alcançado ainda o estágio do desenvolvimento lógico formal. Esta atividade é então uma oportunidade de promover tal desenvolvimento e uma estruturação cognitiva que possibilite o avanço nos estágios formais do pensamento. A 
intervenção do professor ao final da argumentação tem a intenção de levar os alunos a recordarem definições essenciais para a realização do trabalho, estabelecendo então um padrão dialógico interativo de autoridade com a finalidade de apontar a um determinado ponto de vista, provocando uma desequilibração e revisão conceitual.

Entretanto, muitas vezes uma dialogia interativa não é possível, pois a intervenção do professor é realizada com a finalidade de levar o aluno a observar características do fenômeno que não apresentam a ele significado (60 a 70), justamente por não haver uma mobididade antecipatória e retroativa do raciocínio.

60. P: Por que eu acho que a sua amostra deve formar uma solução ou muito ácida ou muito básica? Por que quando você fez o ensaio de chama e colocou a amostra no vidro de relógio, olha o que aconteceu... [mostra o vidro de relógio usado no ensaio]. Ela atacou a espátula. Com certeza ela deve ser muito ácida ou muito básica.

61. P: Vamos usar indicadores. Por exemplo, azul de bromotimol. Se mudar de cor... toda mudança de cor é porque é ácido ou básico... então faça este teste.

$O$ aluno adiciona no tubo de ensaio com a amostra o indicador azul de bromotimol que fica amarelo.

62. P: Está ácido, portanto a sua amostra, quando dissolvida em água, provoca uma hidrólise ácida.

63. P: Agora pensa: quais são os cátions, que quando dissolvidos na água provocam hidrólise ácida? Entendeu a idéia?

64. P: Agora veja, primeira coisa: provoca hidrólise ácida. No ensaio de chama não provoca mudança de cor, portanto, não é nenhum destes aqui... [o professor aponta para a folha de anotação dos alunos].

65. P: O que pode ser?

66. Edvard: É então cloreto de sódio?

67. P: O sódio provoca cor amarela!!! [aponta para a tabela de cores dos espectros luminosos]. Não pode ser o sódio.

68. P: Cloreto de sódio provoca hidrólise?

69. Edvard: ... [inicia uma argumentação, mas permanece em silêncio, então responde...] Não!

70. P: Não! 
É interessante notar que nesta seqüência de argumentos ocorre um exercício da dialética com uma tensão entre opostos, ou seja, o professor afirma que nenhum dos cátions descritos na folha de apontamos pelo aluno poderia constituir sua amostra e o sódio fazia parte desta lista. Ao questionar o aluno sobre qual poderia ser para levá-lo a pensar em outros cátions possíveis o aluno continua afirmando tratar-se do cloreto de sódio (66). Inicia-se então uma dialogia baseada na dialética pela negação, ou seja, não poderia ser o sódio em função dos resultados experimentais e empíricos já obtidos ${ }^{(8)}$.

O professor, numa dialogia não interativa de autoridade, apresenta, através das evidencias a negação da afirmação do aluno e mesmo após tais negações, o aluno não estabelece uma síntese, ou seja, continua ainda afirmando aquilo que a amostra não é. Uma outra seqüência de argumentos que também demonstra esta dificuldade do raciocínio dialético é o ocorrido no episódio 8 (81 a 89).

81. P: Se for brometo, na presença de fluoresceína, ele tem que descorar a fluoresceína. Vamos ver se é brometo.

82. Andrews: Mas o brometo não precipita com o chumbo.

83. P: Não! Você não fez o teste do brometo com o chumbo?

84. Andrews: Fiz!

85. P: Se for brometo, o brometo com o chumbo forma um precipitado branco e cristalino...

...[com o tubo de ensaio na mão mostra o precipitado formado]...

86. P: Então você está achando que é brometo, certo?

87. Andrews: Sim.

88. P: Se realmente for brometo, a amostra, na fluoresceína... se for brometo... descora a fluoresceína.

... [pega então um tubo de ensaio vazio e adiciona a amostra, em seguida goteja a fluoresceína] ...

89. P: Está vendo? Não houve reação. Sua amostra não é brometo. É algum ânion que reage com o chumbo, mas não é brometo.

\footnotetext{
${ }^{(8)}$ Como afirmado por Hegel, a dialética significa a marcha do pensamento que procede por tese, antítese e síntese e reproduz o próprio movimento do Ser absoluto ou Idéia. Neste contexto, Engels afirma que a dialética é a ciência das leis gerais do movimento, tanto do mundo externo quanto do pensamento humano. (ENGELS, 1979).
} 
O aluno, mesmo tomando consciência pelo fenômeno ocorrido, tenta negar o conceito teórico de que o brometo de chumbo é um sal insolúvel em água, por isso ocorre um precipitado. Ele acha que sua amostra é formada por brometo, mas não compreende a reação de precipitação, pois julga que esta não deve ocorrer, todavia, não é capaz de reestruturar seus esquemas mentais e tão pouco refazer os seus planejamentos e continua a insistir nas suas coleções figurais, como já discutido no item 2.1.1, que nos apresentou um outro episódio do conjunto de dados desta pesquisa, não estabelecendo a chamada síntese que o levará a buscar novos conceitos teóricos para as próximas ações.

A estruturação do raciocínio lógico-formal leva o aluno a compreender os esquemas experimentais adotados numa marcha analítica que necessita de uma reversibilidade e antecipação do pensamento e da ação, culminando com uma capacidade dialética de negação a partir daquilo que se observa no fenômeno experimental. Piaget e Inhelder (1975) utilizamse deste conceito para estudar as estruturas do conhecimento durante uma pesquisa sobre as estratégias de resolução de problemas. Embora estas propriedades pareçam antitéticas aquelas que levam à antítese, à oposição, à contradição - elas são interdependentes. Trata-se de um método de pensamento que é também plenamente aplicável às dualidades de assimilação e acomodação "sujeito e objeto", onde ocorre a abstração empírica e a abstração reflexionante, conforme episódio 12 (191 a 202).

191. P: Pelo ensaio de chama vocês eliminaram alguns cátions, e o que vocês acham que é?

192. Adriana: Ou potássio ou cálcio. Pelo ensaio de chama achamos que é isto.

193. P: Agora vocês precisam fazer um ensaio via úmida para eliminar um. Vocês estão fazendo esta escolha baseada em quê?

194. Diogenes: No potássio... pra começar. Ele ... [Vogel] ... fala assim: perclorato de potássio. Se adicionarmos perclorato na nossa amostra ela tem que ficar insolúvel.

195. P: Ta...

196. Diogenes: Então o potássio mais o perclorato tem que precipitar. 
197. P: Então se a gente pegar ácido perclórico, estamos adicionando o perclorato. Então prepara a amostra mãe que eu vou pegar o ácido perclórico.

Adriana prepara o tubo de ensaio colocando a amostra enquanto o professor busca o reagente.

198. Diogenes: Então temos que observar que o ácido perclórico em contato com o potássio tem que formar o quê? Um precipitado branco, cristalino e ... esse precipitado é ligeiramente solúvel em água.

Diogenes pega a pipeta para iniciar o ensaio. Vai então adicionando o ácido perclórico sobre a amostra. Todos observam em silêncio. Agita o tubo de ensaio.

199. Diogenes: Não houve reação nenhuma. Então isto aqui não pode ser potássio.

200. P: Então você conclui que não é potássio?

201. Diogenes: Não é, porque não houve nenhum precipitado. Como diz o livro aqui, o potássio em contato com o ácido perclórico forma um precipitado branco. Então está descartado o potássio.

202. Adriana: Então vamos para o próximo. Que é o cálcio... Vamos ver agora uma reação para o cálcio...

A aproximação entre os conceitos adquiridos nas aulas de Química Analítica Qualitativa, a apropriação das informações contidas no livro de referência (Vogel) e a compreensão das diversas formas de linguagem permitiram aos alunos estabelecer um planejamento das ações através de um pensamento antecipatório e, ao verificar pela experimentação a negação de suas concepções teóricas, são capazes de construírem um novo plano pela reversibilidade do pensamento, demonstrando assim maturação na estruturação de sua estrutura cognitiva.

A organização das idéias através de registros e anotações durante a prática experimental auxilia na organização do raciocínio e provocam a interação entre os alunos (dialogia dos pares), levando-os a uma boa qualidade de argumentação e apropriação das definições, de vocabulário e formação do conceito. Como discutido no item 2.2, Bakhtin estabelece uma tipologia diferenciando os gêneros do discurso entre primários e secundários. A comunicação discursiva que se estabelece entre os alunos e com o professor é de natureza primária e emergem naturalmente, talvez com pouca reflexão e sem estabelecer interações 
conceituais mais profundas. Já os discursos de natureza secundários, ou seja, aqueles escritos, registrados em papel, levam a um raciocino mais complexo e relativamente mais desenvolvido e organizado. É por esta razão que no início da atividade experimental uma das orientações dadas pelo professor era para que os alunos fossem registrando todas as ações na folha de avaliação para que os gêneros secundaristas absorvam e transmutem os gêneros primários (simples) de todas as espécies que se constituem em circunstâncias de uma comunicação verbal mais espontânea.

A intervenção do professor como autoridade descrita no episódio 9 é para que organizem o registro (uma lista). A partir desta ação os próprios alunos estabelecem uma abordagem comunicativa interativa/dialógica como demonstrado nos argumentos 106 a 122.

106. P: Agora tenta observar aqui na tabela quais são os possíveis e quais estão descartados e então monta uma lista com os quais vocês acham possíveis e quais deles vocês acham que já estão descartados.

107. Diogenes: O sódio já está descartado.

108. P: Qual?

109. Diogenes. O sódio, porque ele só tem uma cor só. Então pela chama não pode ser sódio. O tálio também não por que...

110. Adriana: É só verde.

111. Diogenes: Isso.

112. Diogenes: É... o bário também porque tem mais uma cor [referindo-se ao resultado do ensaio]... tem amarelo também. $\mathrm{O}$ potássio... o lítio também não pode ser por que...

113. Adriana: É laranja e vermelho.

114. Diogenes: E na amostra aparece um azul.

115. Diogenes: Então pode ser o potássio.

116. Adriana: Ah, este aí pode ser porque é azul e violeta...

117. Diogenes: Cadê aquela página...

118. P: Olha, azul e violeta.

119. Adriana: São bem próximos... e o verde também.

120. P: Na sua opinião pode ser qual?

121. Diogenes: Pode ser o potássio... ou o estrôncio... cálcio... laranja, verde amarelada violeta fraca.

122. Adriana: Ah! Pode ser esta! 
À medida que as zonas do perfil conceitual vão se delineando, os alunos tornam-se capazes de descrever, explicar e generalizar os fenômenos e as ações tomadas durante a prática experimental, todavia, chegar à capacidade de generalização requer maturação e uma profícua interação entre inteligência e linguagem. (PIAGET, 1967). No desenrolar desta atividade experimental a abordagem do conteúdo ocorre, segundo Mortimer e Scott (2002; 2003), através de uma "estória científica" que é na verdade os conteúdos procedimentais (idealizados na alegoria da aula com aproximação das práticas do cotidiano). Em linhas gerais, consideram-se as formas de abordagem do conteúdo como descritas no quadro 5.

QUADRO 5: Formas de abordagem do conteúdo: descrição, explicação e generalização.

Envolve a produção de enunciados sobre um sistema, um objeto ou um Descrição fenômeno em termos dos seus constituintes ou do deslocamento espaçotemporal desses constituintes.

A descrição é considerada empírica quando feita em termos de aspectos observáveis, e teórica quando realizada a partir de entidades que não são observáveis.

Pode envolver a atribuição de entidades não-observáveis ao sistema, no caso de uma descrição teórica, mas não de um mecanismo causal.

É elaborada no sentido de estabelecer relações causais entre os fenômenos Explicação e os conceitos, usando algum modelo ou mecanismo para a compreensão dos fenômenos.

Da mesma maneira que nas descrições, as explicações podem ser empíricas, quando são elaboradas a partir de aspectos observáveis do fenômeno, e teóricas, quando estão fundamentadas em modelos baseados em aspectos não-observáveis.

Vai além da descrição e da explicação, pelo fato de não estar limitada a Generalização um fenômeno particular, mas expressar propriedades gerais de entidades científicas, da matéria ou de classes de fenômenos.

As generalizações podem ser descritivas ou explicativas por natureza, e, como nos casos anteriores, podem ser consideradas empíricas quando se referem a aspectos observáveis, e teórica, quando os referentes são entidades não-observáveis, normalmente elementos de modelos teóricos.

FONTE: AMARAL, E. M. R.; MORTIMER, E. F. Uma metodologia para análise da dinâmica entre zonas de um perfil conceitual no discurso da sala de aula. In: SANTOS, F. M. T. A pesquisa em Ensino de Ciências no Brasil e suas metodologias. Ijuí: Ed. Unijuí, 2006. 
Podemos exemplificar a capacidade de generalização pela caracterização da cor dos precipitados. Verifica-se pelo estudo da argumentação que a compreensão deste conceito é estruturada cognitivamente de diferentes formas e dele apropriar-se corrobora no planejamento das ações e posterior interpretação dos resultados pela coleção figural que este conceito estabelece.

Como descrito na figura 6 , a cor do precipitado dos halogenetos de prata são fundamentais para distinguir cloretos, brometos e iodetos. Esta capacidade de generalização só é possível se houver uma lógica-formal já estabelecida, caso contrário, os alunos ainda na fase opertório-concreto não serão capazes de utilizarem esta informações para estabelecer uma descrição e uma explicação do fenômeno. A figura do professor, numa abordagem interativa dialógica ou mesmo interativa de autoridade tem como intenção levar o aluno a perceber e compreender esta generalização. Uma parte do episódio 11 (172 a 190), demonstra como a falta de generalização e como o aluno demora a perceber esta característica.

172. P: Olha, usando esta tabela aqui, localiza então aqui nesta tabela onde você tem prata.

173. Fernando: Aqui: acetatos, tiocianatos, cloretos e brometos e sulfatos... e iodetos.

174. P: Então pronto. Você tem uma lista de quais são os ânions que podem reagir com a prata. Então desta lista, pela característica do precipitado, você verifica quem é quem. Que característica te leva a comparar um com outro?

175. Fernando: A característica da amostra.

176. P: Então, se você mistura a prata com a sua amostra ela forma um precipitado. Os precipitados são todos iguais?

177. Fernando: Hummm...

178. P: De maneira geral, uma coisa precipita. Os precipitados são sempre iguais?

179. Fernando: Sim, são.

180. P: Tem sempre a mesma cor?

181. Fernando: São quase sempre brancos.

182. P: Podem ser brancos ou podem ser de outra cor?

183. Fernando: Não, mas de prata são sempre brancos. 
184. P: Então testa aqui e verifica se todo o precipitado é branco.

185. Fernando: Então vou pegar estes aqui ... [referindo-se aos ânions] ... e vou testar com a prata?

186. P: Não sei... verifica aqui no Vogel... quer ver... se você reagir a prata com o cloreto: precipitado branco. Se você reagir a prata com sulfeto: dá um precipitado preto. Então todo precipitado é branco?

187. Fernando: Não!

188. P: Então como é que você vai diferenciar quem é quem?

189. Fernando: Pela cor do precipitado.

190. P: Ah! Então a cor do precipitado te ajuda a diferenciar o ânion? Muito bom!

Já no episódio 22 (545 a 566), os alunos têm clareza de que a cor do precipitado é uma informação importante para orientar a atividade experimental e a utilizam como estratégia de reversibilidade, antecipação e planejamento. Pela compreensão do conceito de precipitado e da diferenciação qualitativa dos ânions pela coloração os alunos foram capazes de realizar o experimento e interpretar seu resultado e buscam, pela reversibilidade do pensamento, estabelecer uma lógica nas evidências para distinguir, entre as várias hipóteses, qual se enquadra no conceito teórico já estruturado que se sobreponha ao conceito empírico obtido.

545. P: Repassa a lista então do que reage com a prata.

546. Arlindo: Acetatos, tiocianatos, cloretos e sulfatos.

547. P: Tem mais!

548. Luciana: Tiossulfatos e brometos.

549. P. Tem mais!

550. Arlindo: Sulfatos, iodetos...

551. Luciana: Isso, iodetos.

552. P: Então repassa: acetatos...

553. Luciana: Tiocianatos, tiossulfatos, cloretos, brometos, iodetos e sulfatos.

554. P: Ok! Agora, todos eles com a prata formam um precipitado. O que é que diferenciaria um precipitado do outro?

555. Arlindo: A cor!

556. P: A cor? 
557. Arlindo: É, a gente viu em um ali que eu não me lembro qual era que forma um precipitado amarelo, só que a nossa amostra formou um precipitado branco.

558. Luciana: Com o nitrato.

559. Arlindo: Foi com o nitrato que formou um precipitado amarelo? Só que a nossa amostra formou um precipitado branco.

560. P: Como assim com o nitrato?

561. Arlindo: O nitrato é solúvel, não é?

562. Luciana: Não, não é com o nitrato.

Começam a folhear o Vogel.

563. P: Olha, vocês precisam fazer agora é fazer uma separação de quem é quem pela cor do precipitado. Então olha: acetato de prata, qual é a cor?

564. Luciana: A gente não tem.

565. P: Vamos fazer o seguinte? Vocês agora relacionam todos os precipitados de prata com a cor e olha no Vogel. Vocês só vão conseguir isso pelo Vogel.

566. Ângela: Ta!

Durante a atividade experimental surgem vários conflitos conceituais que impedem uma operação discursiva do pensamento, o que impede o encadeamento lógico dos juízos, não possibilitando conclusões efetivas, criando assim uma questão antitética, ou seja, de oposição, pois o pensamento antecipatório foi sabotado pelo conflito conceitual. O que chamamos aqui de sabotagem é compreendido quando verificamos que o aluno realizou um conjunto de ações devidamente planejadas num raciocínio lógico-formal sustentado pela reversibilidade, pois ele busca a identificação de um ânion e espera que ocorra sua precipitação com um outro ânion, o que não é possível. Esta sabotagem conceitual ocorre não porque o sujeito não saiba o conceito, mas por um lapso de atenção ou pelas inúmeras informações que são geradas durante o procedimento experimental, o que exige trabalho mental, o que leva o indivíduo à fadiga e a esta sabotagem conceitual. É necessária então a intervenção do outro para restabelecer seu raciocínio lógico-formal. O final do episódio 20 (506 a 528) demonstra esta proposição. 
506. P: Mas você não está pesquisando o ânion?

507. Arlindo: Sim!

508. Então se você jogar ácido sulfúrico você está querendo qual ânion do ácido sulfúrico?

509. Não entendi professor.

510. Arlindo: Quem é o ânion do ácido sulfúrico? Quem é o cátion e quem é o ânion?

... [silêncio $]. .$.

511. P: Escreve a fórmula dele.

512. Arlindo: Está aqui: $\mathrm{H}_{2} \mathrm{SO}_{4} \ldots$ [fala soletrando]...

513. P: Então quem é o cátion?

514. Arlindo: O hidrogênio. Aqui, o cátion!

515. P: E quem é o ânion?

516. Arlindo: Deixa eu pegar a tabela aqui...

517. Arlindo: O sulfato!

518. P: Mas se você está pesquisando o ânion da sua amostra, ânion reage com ânion?

519. Arlindo: Não!

520. P: Então porque você adicionou... teria que ter precipitado ânion com ânion?

521. Arlindo: Não!

522. P: Então neste segundo tubo em que você colocou a amostra mais ácido sulfúrico...

523. Arlindo: Não deveria ter precipitado.

524. P: Então não tem precipitado porque não deveria ter precipitado.

525. Arlindo: Ah ta!

526. P: Entendeu?

527. Arlindo: Entendi. O ânion com o ânion. Deveria ter precipitado só...

528. P: O hidrogênio com o ânion.

Já no episódio 21 descreve uma seqüência de argumentos em que a lógica-formal fica comprometida pelos conflitos conceituais e nesta interação entre os pares, a abordagem comunicativa interativa de autoridade passa a ser não do professor mas de um outro aluno que ajuda a estabelecer a lógica-formal para a compreensão do fenômeno e dirimir o conflito para organização do pensamento reversível. 
529. Arlindo: Mas e ai, vocês acharam que é o quê?

530. Luciana: Então, a gente fez o nitrato de prata com o carbonato... não... com o cloreto de cálcio. E ai formou um precipitado branco.

531. Ângela: Que é este aqui! ... [fala mostrando o tubo de ensaio] ...

532. P: Como vocês fizeram isto? Onde está a amostra de vocês ai?

533. Ângela: É não tem amostra!

534. Luciana: Por quê? Eu estou usando o cloreto.

535. P: E cadê a amostra?

536. Arlindo: Tem que reagir na amostra entendeu?

537. Luciana: Então esquece, não é nada disso.

538. P: Você tem que pegar a amostra e reagir a amostra com o reagente de grupo. Caso a sua amostra seja um cloreto ocorre um precipitado, caso não seja, não ocorre. Neste caso, vocês pegaram um cloreto e reagiram com a prata. Então isto é só para vocês saberem que cloreto com prata precipita. Agora, se você pegar a prata, reagir com a sua amostra e houver um precipitado, provavelmente a sua amostra é de...?

539. Luciana: Cálcio.

540. Ângela: Não, de cloreto.

541. Luciana: Ah, cloreto, entendi.

542. P: Então vocês fizeram um teste e onde está a sua amostra?

543. Ângela e Luciana: Não está!

544. Luciana: Então tem que por a amostra.

Mais uma vez a sabotagem conceitual se antepõe ao planejamento da ação experimental. Motivados pelos conceitos teóricos buscados nas referências (Vogel), os alunos realizam as práticas experimentais confirmando e apropriando-se da teoria que foi verificada num nível fenomenológico. Todavia, não houve o entendimento que a reação química ocorrida deveria envolver a amostra em análise. Há neste caso um obstáculo epistemológico substancialista (BACHELARD, 1938; 1996), pois é constituído por intuições muito dispersas e até opostas. Por uma tendência quase natural, o aluno, numa condição do pensamento précientífico, condensa num objeto todos os conhecimentos sem se preocupar com a hierarquia dos papéis empíricos, ou seja, não percebe que hierarquicamente o foco da pesquisa está na amostra e que são dos resultados experimentais dela obtidos que surgem as evidências a serem analisadas, discutidas e conceituadas. 
No processo de análise e identificação do gênero da abordagem e da argumentação, constata-se que as características do discurso produzido mudam na medida em que idéias associadas a diferentes contextos emergem na discussão da sala de aula. Dessa forma, o aparecimento das zonas do perfil está associado a diferentes aspectos discursivos que constituem o gênero do discurso da ciência escolar. A análise de tais aspectos leva a compreensão da caracterização desse gênero apresentado como secundário por Bakhtin (1953; 2000), constituído por, pelo menos por três diferentes modos de expressão: a comunicação informal ou cotidiana, o uso da terminologia científica e da linguagem matemática. Cada um destes três constituintes apareceu de forma mais ou menos predominante, dependendo de vários aspectos, como as intenções do professor/pesquisador ou a abordagem comunicativa utilizada. Verifica-se também que houve um processo de construção gradativo do modo de falar científico sobre a espontaneidade dos processos físico-químicos e analíticos.

\subsection{Análise das respostas das questões da avaliação teórica}

Como discutido no item 3.1, após a sequiência de aulas e da atividade experimental (objetivo principal desta pesquisa), ocorreu a realização de uma avaliação teórica conceitual formada por sete questões de múltipla escolha. A prova foi respondida por 103 alunos, os mesmos que participaram das atividades experimentais de laboratório. Estes alunos estavam divididos em três turmas e todos eles tiveram as mesmas seqüências de aula e as mesmas práticas experimentais, fundamentadas numa abordagem interacionista (MIZUKAMI, 1986, p. 59) com padrões de comunicação e argumentação entre os pares e com o professor.

Não há a intenção nesta pesquisa de estabelecer uma relação entre os argumentos dos alunos coletados com as imagens em vídeo e as respostas da avaliação, mas sim, evidenciar que a prática de experimental coloca o aluno numa situação empírica com o conceito; já a 
avaliação formal o coloca numa situação teórica com os mesmos conceitos necessários para a compreensão das práticas experimentais. Em ambas as situações se faz necessário um raciocínio lógico-formal e uma capacidade de pensamento reversível e antecipatório para compreender o fenômeno ocorrido ou proposto e ser capaz de coordenar as ações do raciocínio, expressas pela linguagem, o que trás uma ação ou resposta como uma síntese mental da formação dos esquemas conceituais.

O plano de aula da disciplina e o conjunto de atividades têm como prerrogativa dirimir - e porque não dizer abandonar - a idéia de teoria desassociada da prática. Vislumbra-se a necessidade de que o Ensino de Ciência, e por conseqüência o Ensino da Química Analítica Qualitativa, torne-se um corpo a ser estudado e vivenciado pelo estudante ao longo de sua vida escolar. Que a linguagem da Ciência não esteja em desencontro com as suas práticas do cotidiano, tão pouco desvinculadas das suas realidades profissionais. (GIL-PEREZ, 1999).

A intenção desta atividade de avaliação teórica através de um questionário não é colocar o aluno diante de uma ciência imóvel, como insistem os programas de exames universitários, sobre os quais bem afirmou e descreveu Bachelard (1938; 1996, p. 30). Esta atividade tem como propósito levar o aluno a perceber a Química como uma Ciência Natural, que foi elaborada e conceituada com a realização de práticas experimentais, as quais ele pôde realizar e interagir nas atividades realizadas pela prática de pesquisa de cátions e ânions. $\mathrm{O}$ questionário apresenta o problema não mais numa dimensão fenomenológica e empírica, mas sim numa situação teórica onde é possível articular o raciocínio pelas estratégias da dedução, da indução ou da analogia (ARANHA, 1986, p. 100-102), em que é necessário recorrer aos conceitos estruturados e ancorados aos esquemas mentais já estabelecidos pelas seqüências de estudos desenvolvidos ao longo das aulas.

A execução da avaliação teórica requer a capacidade de abstração, ou seja, isolar mentalmente o fato ou a situação descrito para considerar à parte um elemento de uma 
representação que não é dado separadamente na realidade. Isto exige também um raciocínio lógico-formal e uma mobilidade do pensamento para o planejamento teórico estruturado pela reversibilidade e antecipação.

Este momento da pesquisa trás um conjunto de dados que nos auxiliam no entendimento do raciocínio dos alunos na interação com a linguagem escrita, porém a preocupação com o processo é muito maior do que com o produto, como afirma Lüdke e André (1986). Uma adequada aprendizagem escolar promove um tipo de desenvolvimento capaz de permitir uma maior capacidade de abstração, como a que se necessita para produzir um pensamento coerente e fundamentado em argumentos sobre determinado contexto ou sobre determinada situação em um contexto mais amplo. Essa capacidade é básica, porém não é inata nem de desenvolvimento espontâneo, é isto é, precisa ser constituída na relação pedagógica.

\subsubsection{Questões propostas na avaliação e estudo das respostas}

\section{Questão 1}

A seguir estão relacionados alguns produtos comerciais/industriais e as substâncias ativas dos mesmos:

\begin{tabular}{|l|l|}
\hline Produtos comerciais/industriais & Substância ativa \\
\hline Mármore & Carbonato de cálcio \\
\hline Detergente & Amônia (amoníaco) \\
\hline Solução de bateria & Ácido sulfúrico \\
\hline Leite de magnésia & Hidróxido de magnésio \\
\hline Fertilizante & Nitrato de potássio \\
\hline
\end{tabular}

Em relação a esses compostos, é correto afirmar:

1) O detergente amoniacal é ácido.

2) A solução de bateria tem $\mathrm{pH}<7$.

3) O nitrato de potássio é um sal que provoca hidrólise.

4) O leite de magnésia é uma solução ácida.

5) O mármore não reage com $\mathrm{HCl}$.

CORRETA: ( 2 ) 
GRÁFICO 1: Análise estatística percentual das respostas da questão 1.

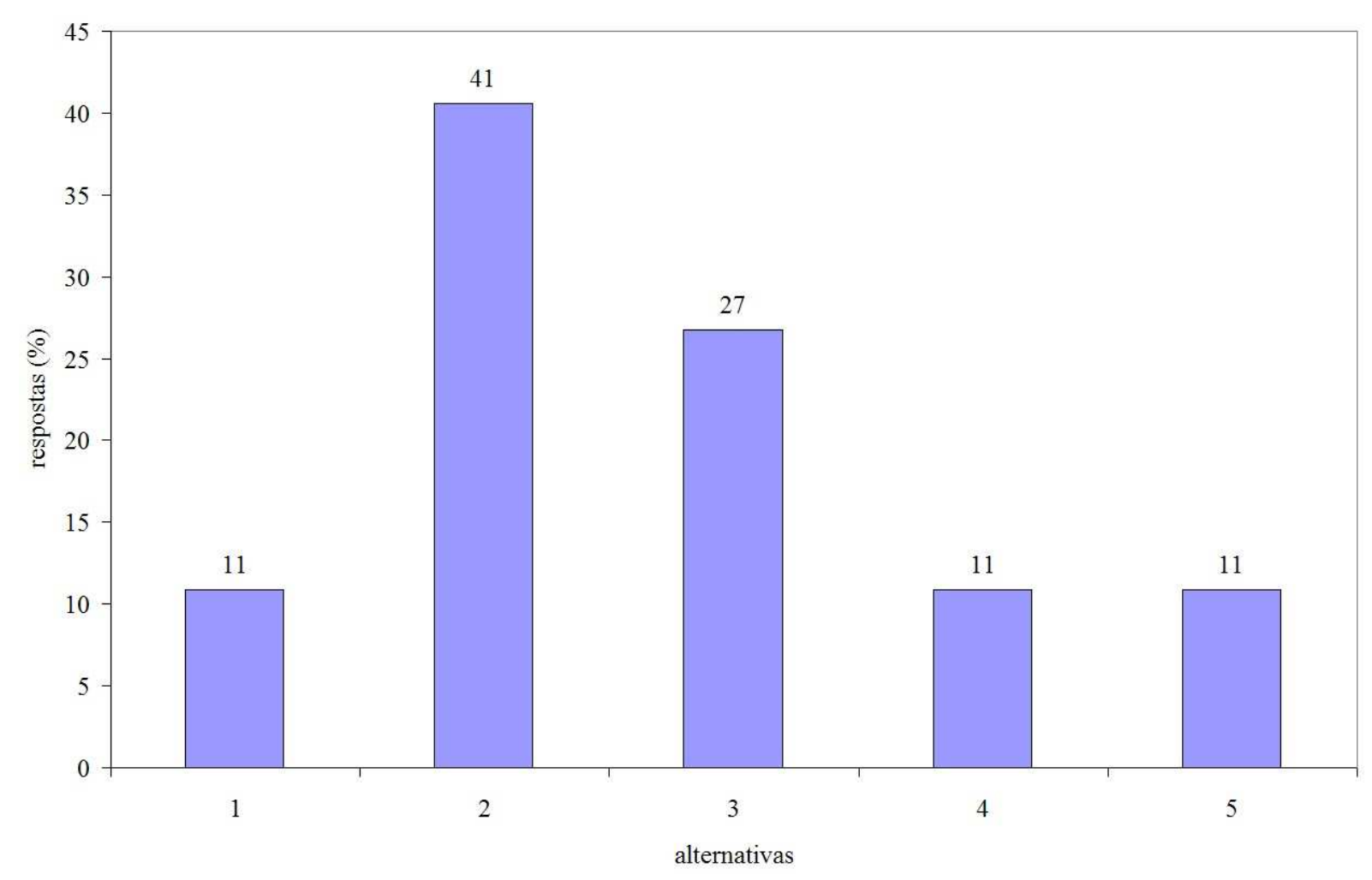

Esta questão propõe uma argumentação conceitual a respeito de produtos comuns do cotidiano. Essencialmente é avaliada a compreensão do conceito de acidez e alcalinidade, bem como sua quantificação numérica (escala de pH). Os resultados demonstram que $41 \%$ dos alunos compreendem este conceito e dominam a linguagem, distinguindo corretamente a representação numérica e a simbologia maior (>) ou menor (<). Todavia, 27\% demonstram não ter clareza do conceito de hidrólise e que isto é resultado da interação de um sal de ácido fraco ou base fraca com a água.

Já os demais alunos (33\%, divididos em três grupos de $11 \%$ ), provavelmente não são capazes de descrever propriedades químicas simples do detergente, por exemplo, que tem como principal função limpar gorduras, por isso é necessário que seja alcalino; ou ainda, de que o leite de magnésia é formado por hidróxido de magnésio (uma base), que é utilizado como medicamento para diminuir a acidez estomacal, por isso não poderia ser ácido. Por fim o conceito de reação do ácido clorídrico com o mármore, que é formado por carbonato de 
cálcio, um sal cujo ânion reage com ácidos por deslocamento do equilíbrio químico, formando gás carbônico, sendo então desgastado.

\section{Questão 2}

Indicador ácido-base é uma substância que, em solução aquosa, apresenta cores diferentes conforme a acidez da solução. O tornassol é um indicador ácido-base muito utilizado em laboratório, sendo extraído de um líquen. Um outro indicador é a fenolftaleína, que está presente no medicamento Lacto-Purga. Ainda podemos utilizar o extrato de repolho roxo ou suco de uva como indicador.

\begin{tabular}{|c|c|c|c|c|}
\cline { 2 - 5 } \multicolumn{1}{c|}{} & Soluģóes & $\begin{array}{c}\text { Tornassol } \\
\text { azul }\end{array}$ & $\begin{array}{c}\text { Tornassol } \\
\text { vermelho }\end{array}$ & $\begin{array}{c}\text { Fenolftaleína } \\
\text { (incolor) }\end{array}$ \\
\hline I & HHO $_{3}$ & vermelho & vermelho & incolor \\
\hline II & $\mathrm{Mg(OH})_{2}$ & azul & azul & vermelho \\
\hline III & sabäo & azul & azul & vermelho \\
\hline IV & detergente & azul & vermelho & incolor \\
\hline V & refrigerante & vermelho & vermelho & incolor \\
\hline
\end{tabular}

A tabela mostra o comportamento de indicadores ácido-base, em presença de diferentes soluções aquosas. Dentre as soluções testadas, aquela que possivelmente é neutra é a:

1) I

2) II

3) III

4) IV

5) $\mathrm{V}$

CORRETA: ( 4 )

GRÁFICO 2: Análise estatística percentual das respostas da questão 2.

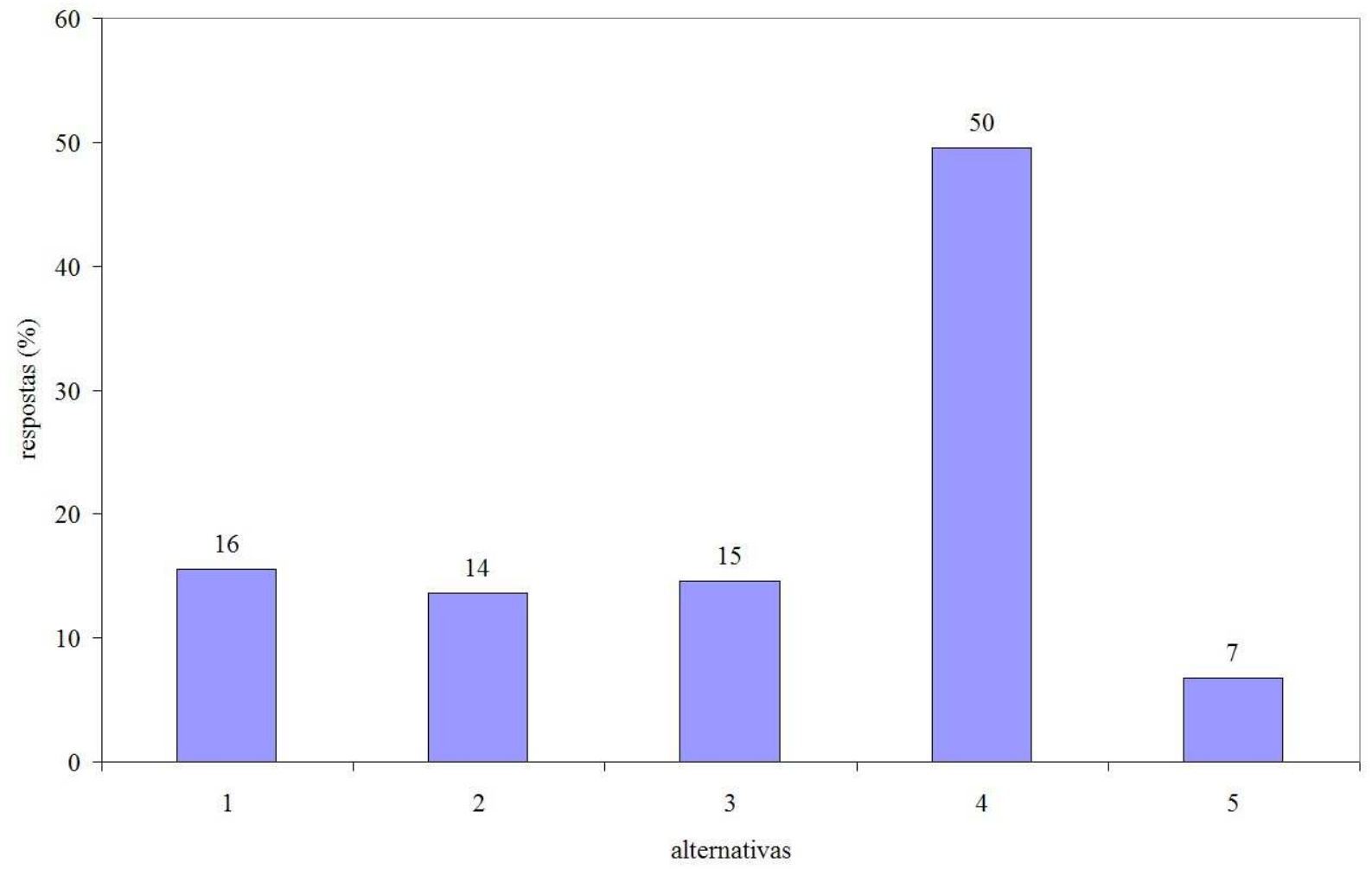


Os indicadores são substâncias que auxiliam na análise de amostras, pois através da mudança de cor classifica-se o meio como ácido ou básico. Para a interpretação da tabela descrita no exercício, o aluno tem que compreender as representações da fórmula do ácido nítrico e do hidróxido de magnésio, para a partir delas estabelecer uma comparação com os demais produtos analisados.

Verifica-se que 50\% dominam a descrição de cores dos indicadores e estabeleceram a relação com o ácido e a base utilizados como referências. Uma outra forma de interpretar o exercício é estabelecendo relações conceituais sobre os demais produtos como o refrigerante que se sabe que é ácido pela sensação ao consumi-lo ou pela memorização das substâncias utilizadas na formulação; de que o sabão é básico para que provoque a limpeza das gorduras; e de que o detergente é neutro pela memorização das propagandas que utilizam como estratégia de publicitária o conceito de neutro para "não agredir as mãos". A análise dos resultados demonstra que metade dos alunos não é capaz de interpretar a tabela, provavelmente não conseguindo utilizar os indicadores como reagente para classificar se uma substância é ácida, básica ou se provoca hidrólise.

Podemos recordar o diálogo do episódio 6 discutido no item 3.2:

61. P: Vamos usar indicadores. Por exemplo, azul de bromotimol. Se mudar de cor... toda mudança de cor é porque é ácido ou básico... então faça este teste.

$O$ aluno adiciona no tubo de ensaio com a amostra o indicador azul de bromotimol que fica amarelo.

62. P: Está ácido, portanto a sua amostra, quando dissolvida em água, provoca uma hidrólise ácida.

63. P: Agora pensa: quais são os cátions, que quando dissolvidos na água provocam hidrólise ácida? Entendeu a idéia?

O aluno, mesmo numa interação dialógica de autoridade não foi capaz de compreender o conceito de hidrólise e argumentar sobre o fenômeno observado no experimento. 


\section{Questão 3}

O esquema mostra observações feitas por um aluno, quando uma chapa de alumínio foi colocada em um tubo de ensaio, contendo solução aquosa de $\mathrm{HCl}$.

Nessa experiência, ocorre o desprendimento de um gás e a formação de um sal, conforme reação abaixo:

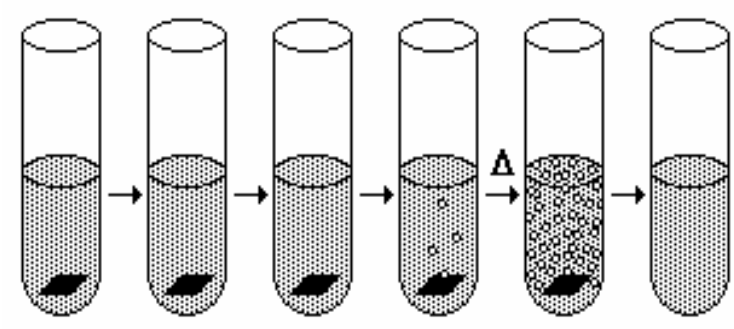

$2 \mathrm{Al}+6 \mathrm{HCl} \rightarrow 2 \mathrm{AlCl}_{3}+3 \mathrm{H}_{2}$

A respeito dela é correto afirmar que:

1) a frio, a reação é forte e processa-se instantaneamente.

2) a reação é acelerada quando o sistema é aquecido.

3) o gás formado é o oxigênio.

4) o sal formado é insolúvel.

5) o alumínio sofre uma redução quando colocado na solução de ácido.

CORRETA: ( 2 )

GRÁFICO 3: Análise estatística percentual das respostas da questão 3.

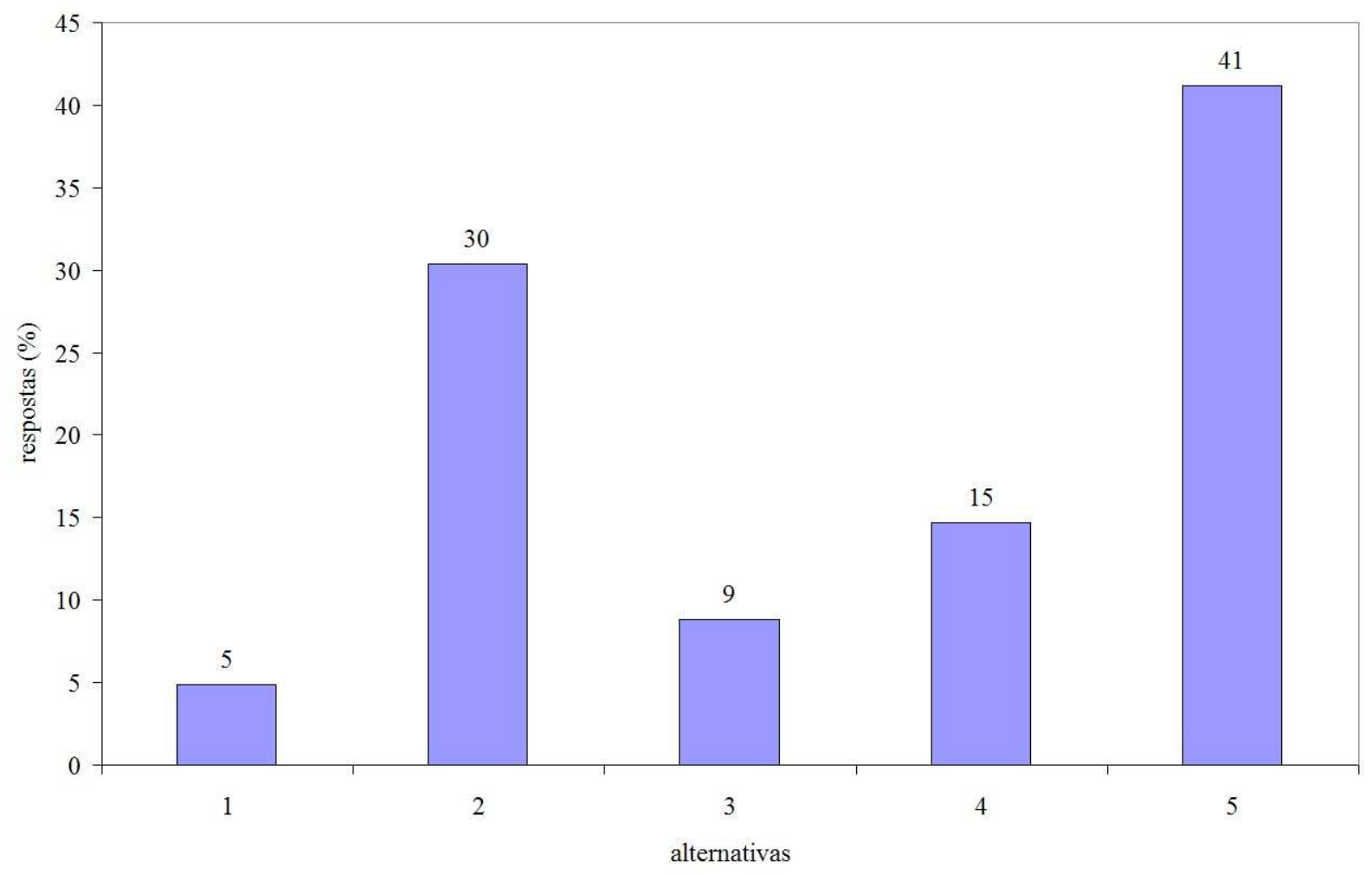

A reação química representada no esquema tem vários aspectos simbólicos que estabelecem uma linguagem semiótica importante para a compreensão do fenômeno. O 
primeiro aspecto que deve ser percebido é a velocidade da reação, pois o esquema demonstra que ela não ocorre instantaneamente. Porém, há uma simbologia que descreve uma que a acelera: o aquecimento, representado pelo delta $(\Delta)$. À medida que o tubo de ensaio é aquecido a velocidade da reação aumenta, há formação de gás (representado pelas bolhas), até a oxidação total do alumínio, deixando-o solubilizado no meio como $\mathrm{Al}^{3+}$.

Apenas $30 \%$ dos alunos compreendem a simbologia utilizada para a representação do fenômeno e demonstram compreender que a temperatura é uma condição física importante para que se processe a reação. Já $41 \%$ dos alunos compreendem que está ocorrendo uma reação entre o ácido e o alumínio, mas não dominam o conceito de oxidação e redução que são fundamentais para a justificação da reatividade dos metais. Talvez entendam o conceito "redução" como desaparecer, ser reduzido e não como um conceito químico de um íon que está diminuindo seu número de oxidação (Nox). Podemos recordar aqui os fundamentos teóricos do item 2.1.1 em que La Taille (2003) teoriza as situações evanescentes propostas por Piaget. A compreensão do fenômeno químico representado teoricamente no esquema da questão necessita que o aluno tenha a estruturação cognitiva sensório-motor maturada, caso contrário compreenderá o fenômeno, tanto no nível fenomenológico como no nível teórico, como um processo de "desaparecimento".

Numa situação empírica e experimental, a não compreensão da reatividade entre um metal e ácidos (ou bases) levará o aluno a não estabelecer procedimentos técnicos durante a marcha analítica como o argumento 27, 28 e 29 do episódio 4 e o argumento 60 do episódio 6.

27. P: Aqui vocês podem fazer uma amostra maior. Coloque mais amostra e mais água. Mas não deixe a espátula dentro do Becker. Se a sua amostra for ácida ou básica ela vai atacar a espátula. Ácidos e bases não atacam metal?

28. Thiago: ...[confirma com a cabeça]...

29. P: A espátula não é de metal? Então vai haver uma reação contaminando sua amostra mãe. 
60. P: Por que eu acho que a sua amostra deve formar uma solução ou muito ácida ou muito básica? Por que quando você fez o ensaio de chama e colocou a amostra no vidro de relógio, olha o que aconteceu... [mostra o vidro de relógio usado no ensaio]. Ela atacou a espátula. Com certeza ela deve ser muito ácida ou muito básica.

A equação química representada e o texto do exercício indicam que há formação de um gás, mas provavelmente, $15 \%$ dos alunos associam espontaneamente a palavra gás com o oxigênio, não percebendo que esta substância não está presente entre os reagentes, portanto não é possível obtê-la como produto. Este é um obstáculo epistemológico do tipo substancialista, pois prevalece a experiência externa, mas escapa à crítica pelo mergulho na intimidade do conceito. (BACHELARD, 1938, 1996).

\section{Questão 4}

Analise o fluxograma abaixo:
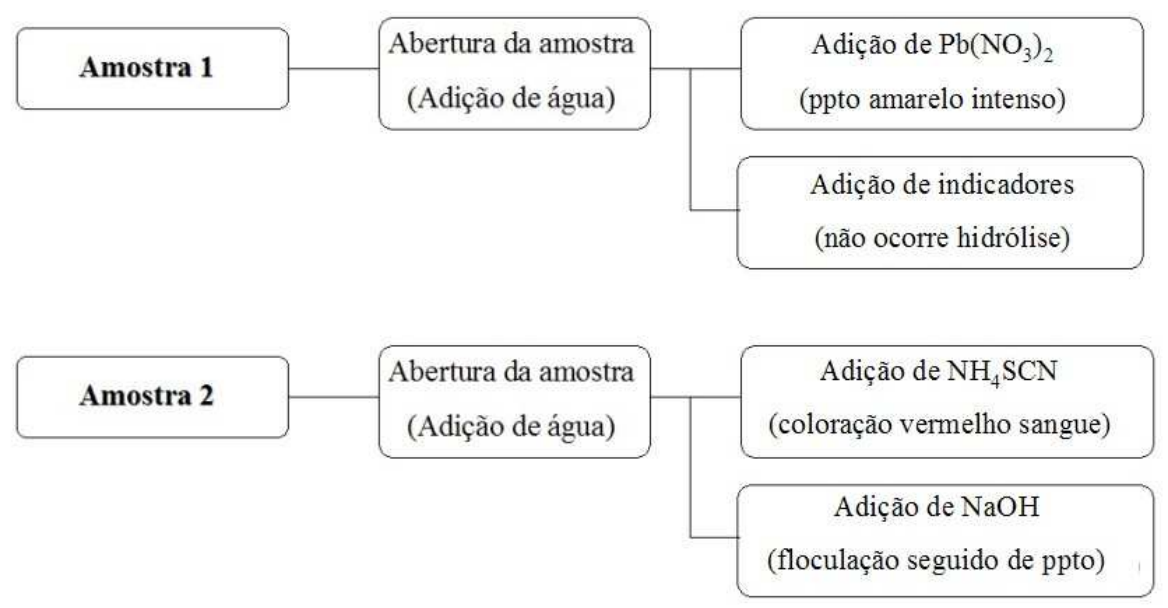

A partir das evidências descritas, pode-se supor que as amostras 1 e 2 são formadas pelos ânions e/ou cátions respectivamente:
1) $\mathrm{SO}_{4}{ }^{2-} \mathrm{e} \mathrm{I}^{-}$
2) $\mathrm{NH}_{4}{ }^{+} \mathrm{e} \mathrm{BO}_{3}{ }^{3-}$
3) $\mathrm{Pb}^{2+} \mathrm{e} \mathrm{Cl}^{-}$
4) $\mathrm{I}^{-} \mathrm{e} \mathrm{Fe}^{3+}$
5) $\mathrm{CO}_{3}{ }^{2-} \mathrm{e} \mathrm{Cl}^{-}$ 
GRÁFICO 4: Análise estatística percentual das respostas da questão 4.

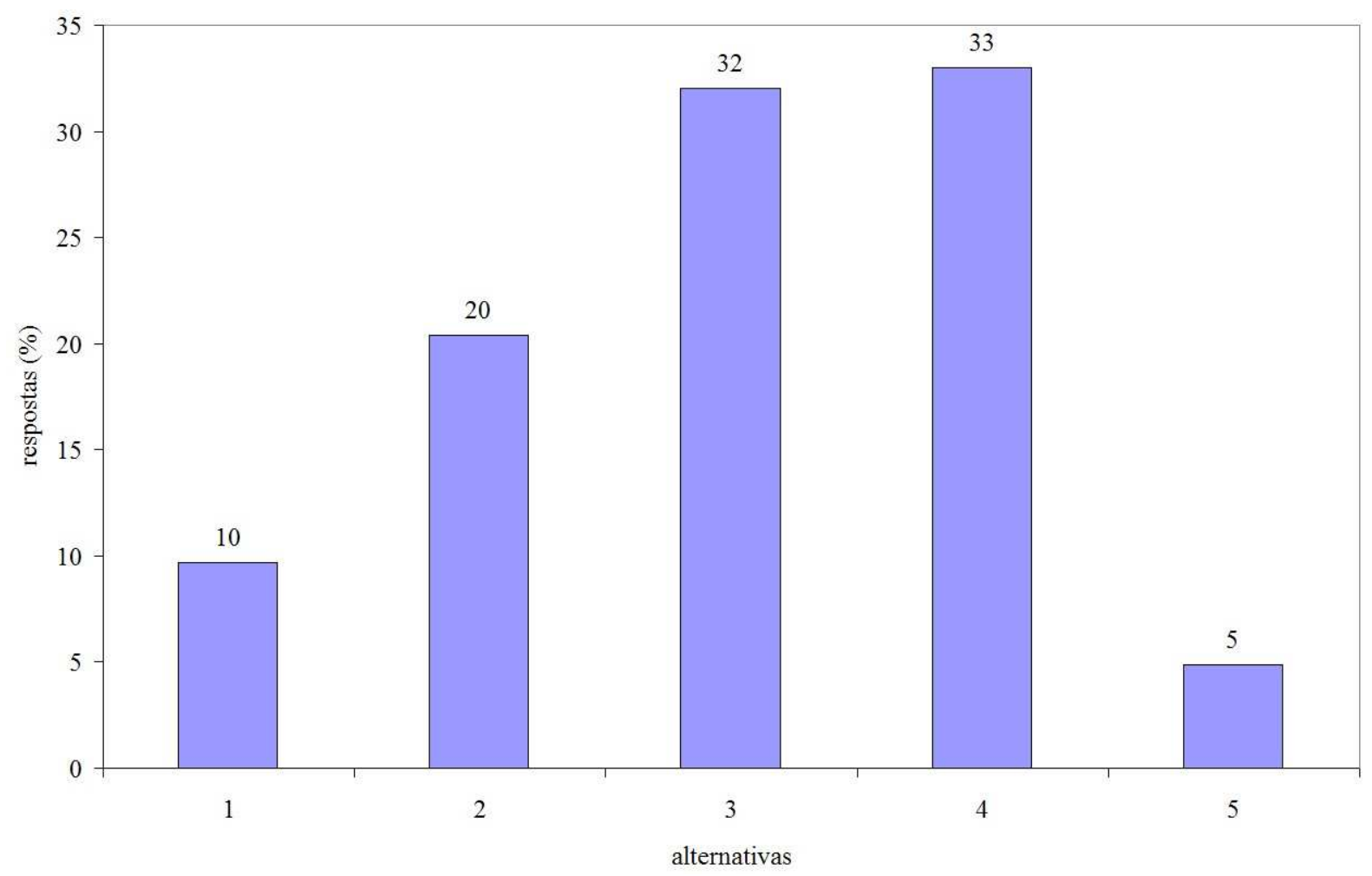

Esta questão investiga a compreensão de duas seqüências de marchas analíticas e a interpretação dos resultados obtidos na determinação do cátion e ânion que formam as amostras. Ambas as amostras foram diluídas em água e não há informação se são solúveis ou insolúveis. $\mathrm{Na}$ amostra 1 , ao adicionar $\mathrm{Pb}\left(\mathrm{NO}_{3}\right)_{2}$ ocorre a formação de um precipitado amarelo intenso, ao adicionar indicadores não ocorre hidrólise. A interpretação deste esquema inicia-se na compreensão de que todos os nitratos são solúveis, portanto a reação ocorrida só pode ter sido provocada pelo $\mathrm{Pb}^{2+}$ que reagiu com o ânion da amostra. Como o precipitado formado é amarelo intenso, o ânion que, ao reagir com o $\mathrm{Pb}^{2+}$ forma uma substância com esta característica é o iodeto. Ao testar a hidrólise com indicadores verifica-se que este fenômeno não ocorreu, portanto a amostra é formada por um sal de ácido forte e base forte, ficando evidente que a amostra é formada pelo ânion $\mathrm{I}^{-}$.

Sobre a amostra 2, o fluxograma também não descreve se trata-se de uma amostra solúvel ou insolúvel. Ao adicionar tiocianato de amônio $\left(\mathrm{NH}_{4} \mathrm{SCN}\right)$ ocorre a formação de uma substância de coloração vermelho sangue. Há evidência de que houve a formação de um íon 
complexo de hexaciano ferrato $\left(\mathrm{Fe}\left[\mathrm{Fe}(\mathrm{SCN})_{6}\right]\right)$ que é solúvel. Para a confirmação foi adicionado $\mathrm{NaOH}$ havendo então floculação e precipitação, sendo a amostra formada então por $\mathrm{Fe}^{3+}$.

As alternativas propostas indicam as prováveis associações do cátion e ânion que formam a amostra 1 e 2 . Apenas $33 \%$ dos alunos estabelecem a relação correta entre as evidências descritas. Os demais alunos não relacionam as interações entre a descrição no fluxograma e os íons propostos. Verifica-se que não há compreensão dos conceitos utilizados para descrever os fenômenos e tão recorrem às coleções figurais para interpretar as evidências percebidas durante a análise. Esta capacidade cognitiva é importante para a interpretação da descrição e reconhecimento dos cátions e ânions pesquisados.

\section{Questão 5}

Considere o aparelho abaixo:

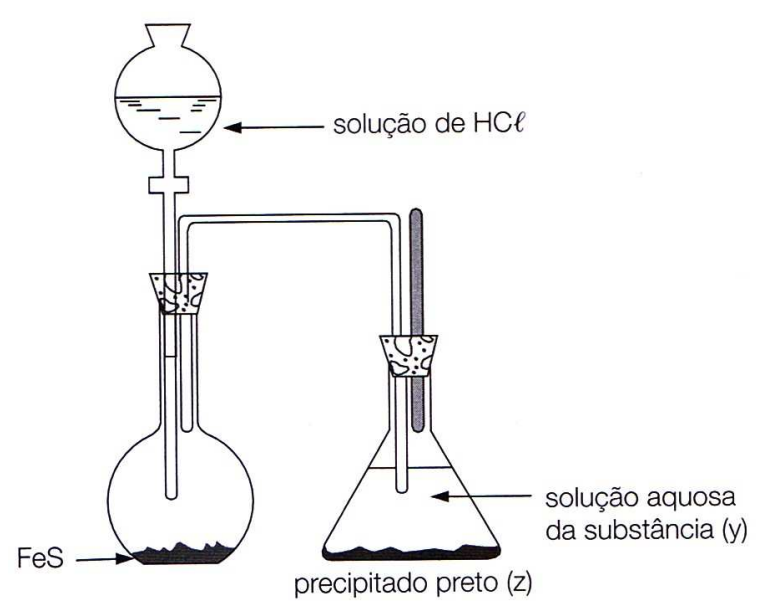

Adicionando-se ácido clorídrico ao balão, há uma reação com desprendimento de gás (x), que, ao borbulhar na solução contida no erlenmeyer, reage, produzindo um precipitado preto $(\mathrm{z})$. O gás (x), a substância (y) e o precipitado (z) são respectivamente:

1) $\mathrm{SO}_{2}, \mathrm{~Pb}\left(\mathrm{NO}_{3}\right)_{2}, \mathrm{PbSO}_{3}$

2) $\mathrm{SO}_{2}, \mathrm{NaNO}_{3}, \mathrm{Na}_{2} \mathrm{SO}_{3}$

3) $\mathrm{H}_{2} \mathrm{~S}, \mathrm{~Pb}\left(\mathrm{NO}_{3}\right)_{2}, \mathrm{PbS}$

4) $\mathrm{H}_{2} \mathrm{~S}, \mathrm{NaNO}_{3}, \mathrm{Na}_{2} \mathrm{~S}$

5) $\mathrm{H}_{2} \mathrm{~S}, \mathrm{~Pb}\left(\mathrm{NO}_{3}\right)_{2}, \mathrm{~Pb}(\mathrm{OH})_{2}$ 
GRÁFICO 5: Análise estatística percentual das respostas da questão 5.

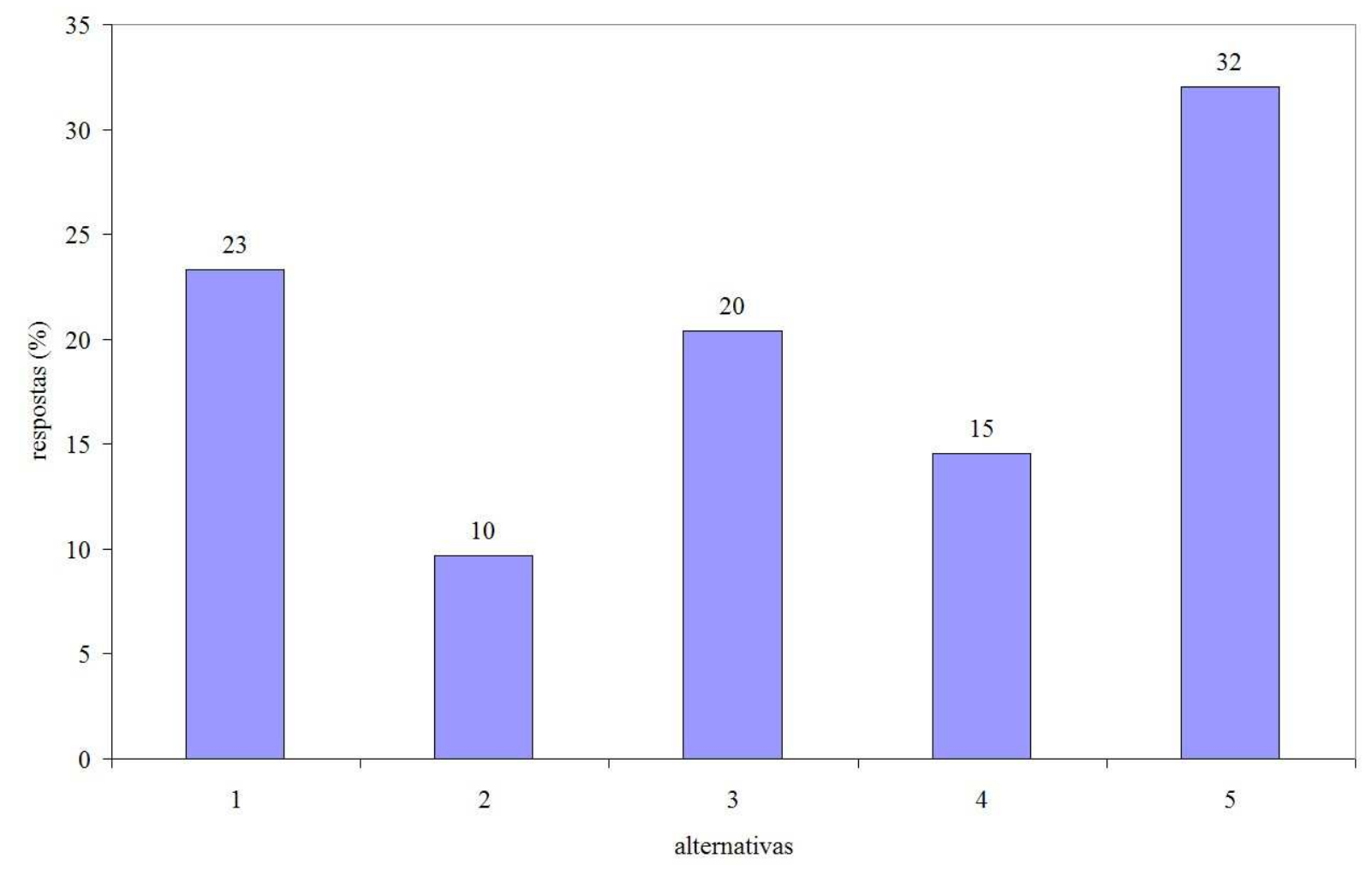

A interpretação e entendimento dos esquemas de análise são fundamentais para a execução dos procedimentos realizados numa análise qualitativa, visto que muitas metodologias, manuais de laboratório e referências para as análises utilizam-se deste recurso para ilustrar o procedimento realizado durante uma determinada análise. Este exercício verifica se há por parte do aluno competências na interpretação do esquema e reconhecimento das substâncias envolvidas nas diversas etapas, avaliando a compreensão do fenômeno de transformação ocorrido quando há reação do ácido clorídrico com o sulfeto de ferro, formando então ácido sulfídrico, um produto gasoso que é então borbulhado numa solução de

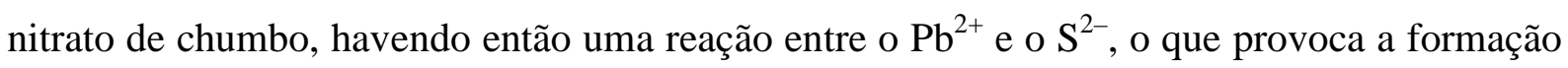
do $\mathrm{PbS}$, que precipita no erlenmayer.

Apenas $20 \%$ dos alunos são capazes de interpretar corretamente o esquema reconhecendo as substâncias envolvidas e, conseqüentemente, justificando estas reações. A grande maioria dos alunos, 32\%, reconhece a formação do ácido sulfídrico, bem como a 
solução de nitrato de chumbo, mas interpretam a formação do precipitado como hidróxido de chumbo. Nesta interpretação há dois erros conceituais, o primeiro referente à formação de uma base, sendo o produto gasoso borbulhado um ácido; e o segundo diz respeito à formação de um precipitado de $\mathrm{Pb}(\mathrm{OH})_{2}$, quando não é possível haver esta formação, visto que o $\mathrm{Pb}^{2+}$ é um metal anfótero e em meio alcalino ou ácido torna-se solúvel.

\section{Questão 6}

Uma liga metálica constituída pelos metais $\mathrm{Hg}, \mathrm{Cu}$ e $\mathrm{Zn}$ foi dissolvida e uma análise qualitativa para identificação dos íons resultantes $\left(\mathrm{Hg}^{2+}, \mathrm{Cu}^{2+} \mathrm{e} \mathrm{Zn}^{2+}\right)$ foi realizada. O esquema a seguir mostra as etapas envolvidas na análise:
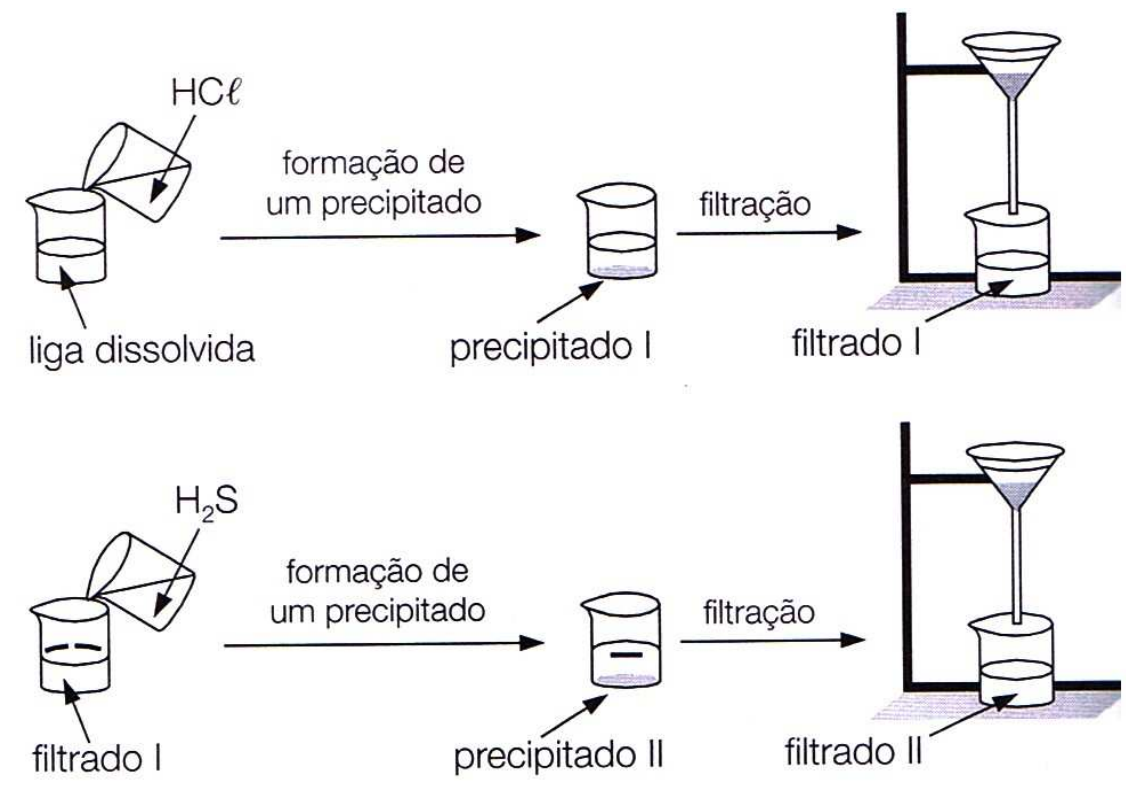

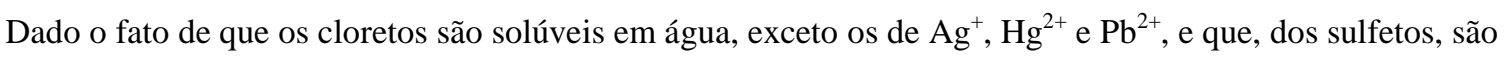
solúveis somente aqueles de metais alcalinos e alcalinos terrosos, pode-se afirmar que:

1) o filtrado I não contém íons de cobre (II) e zinco (II) em meio aquoso.

2) o precipitado II é constituído de cloreto de zinco e cloreto de cobre.

3) o filtrado II é uma solução saturada em íons cobre (II) e zinco (II).

4) o precipitado I é constituído de cloreto de mercúrio (II), $\mathrm{HgCl}_{2}$.

5) o filtrado II é uma solução azulada.

CORRETA: ( 4 ) 
GRÁFICO 6: Análise estatística percentual das respostas da questão 6.

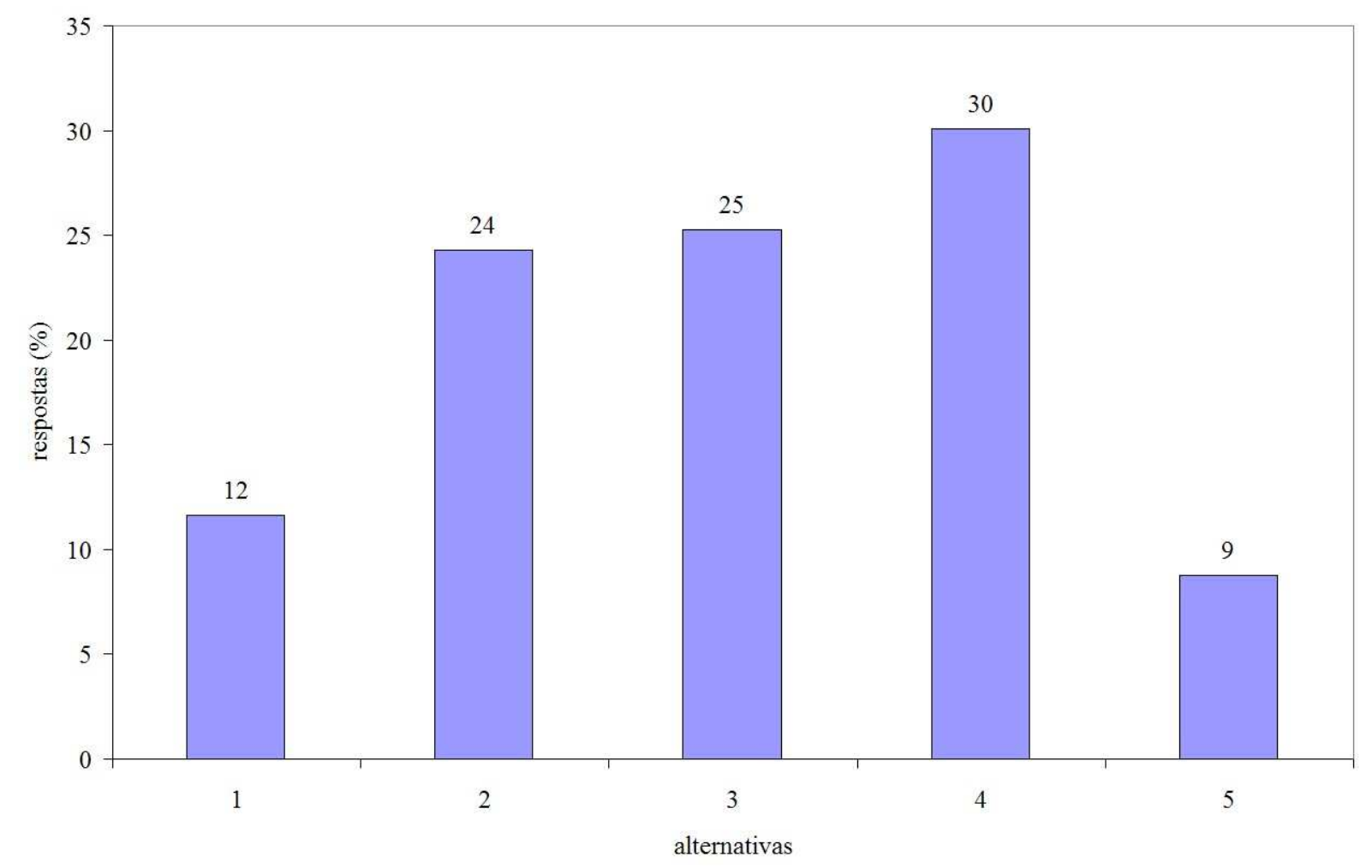

O exercício propõe uma seqüência analítica para a separação de três metais que formam uma liga metálica. Ao adicionar $\mathrm{HCl}$ ocorre um ataque à esta liga oxidando os metais, havendo então a formação dos cátions $\mathrm{Hg}^{2+}, \mathrm{Cu}^{2+} \mathrm{e} \mathrm{Zn}^{2+}$. Como o ácido utilizado foi o ácido clorídrico, o cloreto $\left(\mathrm{Cl}^{-}\right)$reage com o íon mercúrio II $\left(\mathrm{Hg}^{2+}\right)$, havendo então a formação de um precipitado, o $\mathrm{HgCl}_{2}$. O sistema é então filtrado, restando então no filtrado I os íons $\mathrm{Cu}^{2+}$ e $\mathrm{Zn}^{2+}$. O filtrado I é então tratado com ácido sulfídrico, ocorrendo então a reação entre o $\mathrm{S}^{2-}$ e os íons de $\mathrm{Cu}^{2+}$ (precipitado preto) e $\mathrm{Zn}^{2+}$ (precipitado branco), sendo então o material novamente filtrado, não restando praticamente nenhum dos íons metálicos no filtrado II.

O procedimento descrito no exercício requer uma capacidade cognitiva do aluno de pensar reversivelmente para estabelecer relações entre as etapas do processo, os reagente e substâncias utilizadas e compreensão dos fenômenos ocorridos. Este tipo de procedimento é bastante comum numa análise qualitativa e sua execução baseia-se na capacidade do analista 
de reconhecer os metais, estabelecer etapas para a análise e adicionar reagentes específicos que provoquem transformações que possibilitem a separação dos cátions e ânions de interesse. Apenas 30\% dos alunos demonstram compreender as etapas propostas e possuírem uma mobilidade antecipatória do pensamento para, a partir das definições conceituais informadas no problema, estabelecerem uma correta relação com as etapas realizadas e os precipitados obtidos.

Os demais alunos podem até compreender as etapas do esquema analítico, mas não interpretam os resultados obtidos, não reconhecendo os produtos solúveis e insolúveis por não dominarem conceitos fundamentais como quais são os metais alcalinos e alcalinos terrosos.

\section{Questão 7}

Nas cinco equações químicas enumeradas abaixo, estão representadas reações de simples troca, também chamadas reações de deslocamento.

1) $\mathrm{Fe}_{(\mathrm{s})}+2 \mathrm{AgNO}_{3(\mathrm{aq})} \rightarrow \mathrm{Fe}\left(\mathrm{NO}_{3}\right)_{2(\mathrm{aq})}+2 \mathrm{Ag}_{(\mathrm{s})}$

2) $3 \mathrm{Ni}_{(\mathrm{s})}+2 \mathrm{AlCl}_{3(\mathrm{aq})} \rightarrow 3 \mathrm{NiCl}_{2(\mathrm{aq})}+2 \mathrm{Al}_{(\mathrm{s})}$

3) $\mathrm{Zn}_{(\mathrm{s})}+2 \mathrm{HCl}_{(\mathrm{aq})} \rightarrow \mathrm{ZnCl}_{2(\mathrm{aq})}+\mathrm{H}_{2(\mathrm{~g})}$

4) $\mathrm{Sn}_{(\mathrm{s})}+\mathrm{Cu}\left(\mathrm{NO}_{3}\right)_{2(\mathrm{aq})} \rightarrow \mathrm{Sn}\left(\mathrm{NO}_{3}\right)_{4(\mathrm{aq})}+2 \mathrm{Cu}_{(\mathrm{s})}$

5) $2 \mathrm{Au}_{(\mathrm{s})}+\mathrm{MgCl}_{2(\mathrm{aq})} \rightarrow 2 \mathrm{AuCl}_{(\mathrm{aq})}+\mathrm{Mg}_{(\mathrm{s})}$

Analisando essas equações, com base na ordem decrescente de reatividade (eletropositividade) mostrada a seguir,

$\mathrm{Mg}>\mathrm{Al}>\mathrm{Zn}>\mathrm{Fe}>\mathrm{Ni}>\mathrm{H}>\mathrm{Sn}>\mathrm{Cu}>\mathrm{Ag}>\mathrm{Au}$,

pode-se prever que devem ocorrer espontaneamente apenas as reações de número:

1) 1,3 e 4

2) 2,3 e 5

3) 1,2 e 3

4) 3,4 e 5

5) todas ocorrem

CORRETA: ( 1 ) 
GRÁFICO 7: Análise estatística percentual das respostas da questão 7.

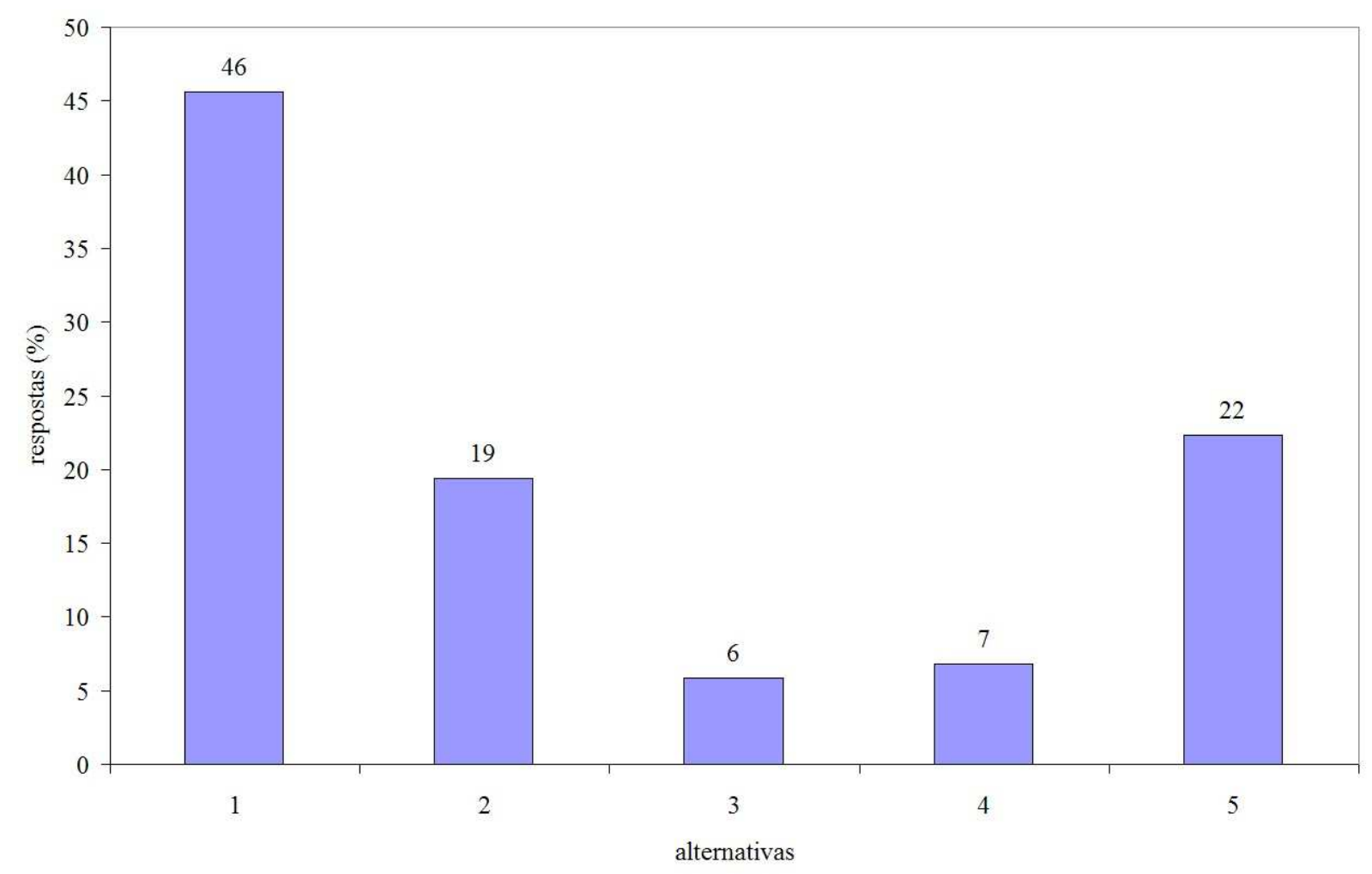

Inúmeras reações químicas ocorrem a todo instante e representá-la através de equações é uma das formas de linguagem empregadas na ciência, sendo fundamental para o Químico compreender esta representação e interpretá-la. A própria fórmula dos elementos e das moléculas já é uma simbologia a ser dominada, e quando elas são organizadas numa seqüência para demonstrar um fenômeno ocorrido utiliza-se de números que representam as quantidades da matéria que participam do fenômeno, o qual chamamos de equação química. Além disso há a utilização de símbolos que descrevem o estado em que a substância se encontra, ou seja, sólido (s), líquido (1), em solução aquosa (aq), gasoso (g) ou vapor (v).

Para que uma reação química ocorra é necessário que as substâncias envolvidas sejam reativas. A físico-química descreve esta característica como espontaneidade e, através de conceitos termodinâmicos de entalpia $(\Delta \mathrm{H})$, entropia $(\Delta \mathrm{H})$ e energia livre $(\Delta \mathrm{G})$ é possível calcular quantitativamente a espontaneidade das reações. Quando estas reações envolvem metais, utiliza-se o conceito de "reatividade dos metais", onde, a partir das medidas da 
diferença de potencial (ddp) entre os eletrodos destes metais construiu-se uma tabela de potencial de redução. Desta tabela surge então a fila de reatividade dos metais que se inicia nos mais reativos, portanto menos nobres, para os mais reativos, mais nobres. A partir desta tabela e de sua compreensão, é possível antecipar se uma determinada reação ocorrerá ou não.

O exercício de estudo propõe cinco reações químicas entre diferentes metais com sais e $\mathrm{HCl}$, ou seja, um metal no estado metálico e outro metal no estado iônico e $\mathrm{H}^{+}$. Se a reação ocorrer, o metal sofrerá oxidação, tornando-se um íon e o outro metal que se encontra no estado iônico tornar-se-á um metal no estado reduzido, bem como o $\mathrm{H}_{2}$. Utilizando a fila de reatividade descrita no próprio exercício, o aluno deve ser capaz de interpreta-la e a partir dela reconhecer as reações que ocorrem ou não.

Verifica-se que apenas $46 \%$ dos alunos estabelecem esta relação entre a fila de reatividade, os conceitos em que ela se fundamenta e antecipam mentalmente as reações que efetivamente ocorrerão. Já os restantes dos alunos não dominam corretamente o conceito, sendo que $19 \%$ provavelmente compreendem a fila de reatividade numa lógica contrária à descrita e $22 \%$ não são capazes de justificar as reações utilizando a fila de reatividade, pois provavelmente não foram capazes de interpretá-la, julgando que todas as reações químicas ocorrem.

\subsection{A articulação entre a atividade experimental e a atividade teórica}

A extrema complexidade do mundo atual não mais permite que o Ensino de Química Analítica Qualitativa - e porque não dizer o Ensino de Química - seja apenas para preparar o aluno para uma relação teórica, matemática e que tenha como verificação da eficácia de suas ações uma avaliação conceitual, vista como fase terminal do processo, em que o estudante é perito, porque é treinado em resolver questões que exigem sempre a mesma resposta padrão. 
O mundo atual exige que o profissional se posicione, julgue e tome decisões, e seja responsabilizado por isso. Essas capacidades mentais são construídas nas interações sociais vivenciadas nas escolas e nas universidades, em situações complexas que exigem novas formas de participação, de comportamento e de raciocínio. Para isso, não nos serve mais componentes curriculares desenvolvidos com base em treinamento para respostas padrão. Um projeto pedagógico institucional e um plano de ensino adequado não é avaliado pelo número de exercícios propostos e resolvidos, mas pela qualidade das situações propostas, em que os estudantes e professores, em interação, terão de produzir conhecimentos contextualizados.

Numerosos estudos têm mostrado que o Ensino de Ciências transmite, por exemplo, visões empírico-indutivista que se distanciam largamente da forma como se constroem e produzem os conhecimentos científicos. (GIL-PEREZ, 2001). Incoerentemente, o ensino científico foi reduzido basicamente à apresentação de conhecimentos previamente elaborados, sem dar oportunidade aos estudantes de constatarem e explorarem atividades na perspectiva de um ensino tipo investigativo. Por tudo isso, as concepções dos estudantes não se afastam daquela imagem em que a Ciência é uma ação infalível.

Compreende-se que toda estratégia pedagógica adquire sentido e importância em função, entre outros fatores, da opção epistemológica do seu autor. Tudo isso recoloca a necessidade de se estabelecer o que deve entender-se por uma visão aceitável do trabalho científico. Há consciência da dificuldade de falar em uma "imagem correta" da construção do conhecimento científico, que parece sugerir a existência de um método científico universal, de um modelo único de mudança científica. É então nesta perspectiva que se percebe a importância das atividades experimentais da disciplina de Química Analítica Qualitativa para o desenvolvimento das capacidades cognitivas e estruturação do pensamento reversível e antecipatório. A investigação fenomenológica que se processa na marcha analítica corrobora para o desenvolvimento da argumentação e oportuniza aos estudantes o vivenciar da 
construção dos conceitos científicos tentando romper então com aquela visão empíricoindutivista apontada por Gil-Perez. Não se pretende dizer que somente isso basta para orientar corretamente o processo de ensino e aprendizagem de Química Analítica Qualitativa, mas pensamos que esta metodologia constitui uma valiosa e determinante contribuição, e que, por outro lado, facilita a assunção das propostas derivadas de outras linhas de investigação didática. 


\section{CONSIDERAÇÕES FINAIS}

A partir dos estudos realizados podemos afirmar que esta pesquisa tem a intenção de realizar uma investigação a respeito das inter-relações entre os processos de ensino e aprendizagem durante as aulas de Química Analítica Qualitativa. Neste sentido, a nossa pesquisa aproxima-se dos trabalhos da professora Carvalho (2006) que nos orienta a procurar e entender como e o porquê o aluno aprende (ou não) quando o professor ensina. Foi então de seus estudos a respeito do Ensino de Ciências e Ensino de Física que nos apropriamos de suas bases teóricas para as relacionarmos com o Ensino de Química Analítica Qualitativa e construirmos então nossas teorias.

O laboratório e as práticas experimentais são o espaço e a forma para o aluno colocar em prática as aquisições teóricas e metodológicas adquiridas durante as aulas. Na verdade, entendemos que entre o laboratório é a própria sala de aula não deva haver uma distância formal: a sala como um espaço com cadeiras, carteiras, lousa, giz e o laboratório com suas bancadas, reagentes, equipamentos. Nestes espaços ocorrem aprendizados, cada um ao seu modo, não havendo um espaço melhor para aprender e outro para praticar. Em ambos se aprende e em ambos se pratica, havendo uma coesão das ações pedagógicas do Ensino de Química para compor uma proposta que seja realística e momentaneamente mais adequada.

Na prática experimental passa-se a trabalhar a mobilização, a orquestração, a sinergia e a contextualização de saberes já construídos, mas que o estudante ainda não pôde utilizar diante de situações complexas, todavia, se estes saberes não foram adequadamente construídos, a mediação do professor, pela argumentação o levará a transpor este obstáculo epistemológico para a total compreensão do conceito, estabelecendo assim uma delimitação da zona do perfil conceitual. 
No Ensino de Química, mais especificamente no Ensino de Química Analítica Qualitativa, o laboratório sempre exerceu um papel de repetição de procedimentos, de protocolos e confirmação dos conceitos teóricos estudados, sendo até mesmo uma ocasião para um simples treinamento sensório-motor. Quando o laboratório e as práticas de Química Analítica Qualitativa assumem um papel de investigação, de argumentação e tem como principal função o exercício do raciocínio para levar o estudante à formação de suas estruturas lógico-formal, a disciplina provoca então nos alunos a obrigação de portarem-se como profissionais, a pesar prós e contras de suas ações, a justificar suas escolhas e a refletirem na situação e na ação, sendo avaliados imediatamente pelos colegas e pelo professor.

Sem dúvida, as práticas realizadas nesta atividade didáticas de pesquisa expõem os estudantes a situações simples, mas que exigem uma estruturação dos conceitos e posterior acomodação cognitiva dos mesmos. Para isso eles devem recorrer aos livros, aos referenciais teóricos e a dialogia entre os pares para estruturá-los e assim estabelecer uma ação antecipatória nascida da reversibilidade do pensamento. Este mesmo estudante, ao tornar-se um profissional mais experiente, obterá por meio de diversas fontes, numerosas informações suplementares, visto que atingirá uma maturação de suas estruturas lógicas e, para isto, práticas didáticas, como as descritas nesta pesquisa tornam-se fundamentais. O espaço pedagogicamente construído pelo professor contribuirá para a estruturação destes esquemas mentais e sua mediação durante a argumentação levará o aluno a uma formação em que se fez presente a reflexão, a crítica, a argumentação e a autonomia na execução de tarefas (requisitos fundamentais e muito apreciados num bom profissional da Química).

A situação problema, proposta pelo professor didaticamente, tem por objetivo conduzir o aluno a relacionar as informações obtidas ao longo da interação empírica com a amostra e com os conceitos teóricos já estabelecidos e catalogados ou não mentalmente. Segundo Schön (1994), a maioria dos problemas estabelecem uma relação com algo já 
conhecido e é imediatamente catalogado para transformar uma situação-problema num simples problema.

No mundo concreto da prática, os problemas não chegam às mãos do profissional de uma forma totalmente determinada. Eles devem ser construídos a partir dos materiais extraídos de situações problemáticas, que são intrigantes, constrangedoras e incertas. Para transformar uma situaçãoproblema em simples problema, um profissional tem de cumprir um certo tipo de trabalho. Acima de tudo, tem de descobrir o sentido de uma situação que, em seu ponto de partida, não tem nenhum sentido. (SCHÖN, 1994, p. $65)$.

O mesmo autor acrescenta o seguinte:

Propor um problema também é escolher os "elementos" da situação que serão analisados, é estabelecer os limites da atenção consagrada a eles e impor-lhes uma coerência que permita entender o que não está dando certo e qual é a direção a ser seguida para corrigir tal situação. (SCHÖN, 1994, p. 66).

Assim, o exercício da competência analítica está muito distante de ser um simples exercício de reconhecimento de conceitos teóricos de um caso escolar com aplicação de respostas ortodoxas. É preciso construir tanto o problema quanto a sua solução, refletir, observar os dados em todos os sentidos, dar-lhes consistência, esboçar hipóteses e analisá-lo detalhadamente por meio do pensamento, em um "mundo virtual" onde tudo continua sendo reversível, estabelecendo uma conversa reflexiva com a situação.

Este exercício é então um procedimento de treinamento intensivo em práticas argumentativas em diversos níveis o que leva o estudante a interagir com as questões empíricas e teóricas, o que constitui um comportamento reflexivo. Pode-se então esquematizar esta ação da seguinte forma:

i) Ensino planejado orientado por um currículo que contenha conceitos teóricos, mas que sejam ministrados de tal maneira que a interrogação e a dúvida estejam constantemente inseridas na relação com o saber e que o professor não 
perca nenhuma oportunidade de reorientar a postura dos alunos através de uma abordagem comunicativa.

ii) Um trabalho por meio de situações-problema, o qual exige um dispositivo de argumentação mais preciso no sentido de intervir "instantaneamente" durante a prática analítica, tendo como função inculcar saberes definidos.

iii) $\mathrm{O}$ trabalho em grupo para a realização das práticas para que haja a possibilidade da interação social do conhecimento, relação entre os pares para que haja a possibilidade de confrontar suas opiniões com a dos colegas, que muitas vezes são diferentes e até contraditórias.

iv) A postura e intenção do professor de desenvolver nos alunos uma antecipação das realidades profissionais, desejando ensinar numa relação educativa, estabelecendo uma articulação entre o poder e o saber, de maneira a levar os alunos a avançarem em suas estruturas cognitivas, chegando ao funcionamento lógico-formal de um adulto, conforme estudos de Piaget.

O construtivismo tem sido já bastante divulgado entre os professores de Química como uma possibilidade interessante e inovadora para lidar com a questão da construção do conhecimento em sala de aula. (MORTIMER, 2003, p. 8). O construtivismo, visto como uma teoria de aprendizagem, tem sido um marco importante na forma de conceber o Ensino de Ciência e o Ensino de Química. Apesar da diversidade de concepções que pode abarcar, pelo menos dois pressupostos podem ser reconhecidos nesta pesquisa em linhas gerais: o conhecimento não é transmitido, mas construído ativamente pelos indivíduos, onde aquilo que o sujeito já sabe influencia na sua aprendizagem. Este fato é evidenciado nas dificuldades dos estudantes para internalizar modelos explicativos e aplicá-los corretamente. Essa contribuição do construtivismo é importante, pois é fundamental considerar a idéia do estudante durante a 
argumentação nas aulas e nas práticas experimentais de Química Analítica Qualitativa. A outra contribuição importante do construtivismo está relacionada à proposição de uma aprendizagem ativa, na qual os alunos estão engajados numa atividade experimental, em discussão em grupo em torno de uma atividade que envolve fenômenos químicos, teorias e representações.

Esta pesquisa, seus referenciais teóricos bem como a metodologia adotada envolvem um avanço nos conhecimentos a respeito do Ensino de Química em relação às contribuições do construtivismo. Buscando incorporar contribuições da área, destacamos um artigo de Driver (1999) e outros pesquisadores sobre um redirecionamento fundamental para o aprendizado de Ciências:

(...) aprender Ciências não é uma questão de simplesmente ampliar o conhecimento dos jovens sobre os fenômenos - uma prática talvez denominada mais apropriadamente como estudo da natureza - nem de desenvolver ou organizar o raciocínio do sendo comum dos jovens. Aprender Ciências requer mais do que desafiar as idéias anteriores dos alunos, através de eventos discrepantes. Aprender Ciências requer que crianças e adolescentes sejam introduzidos numa forma diferente de pensar sobre o mundo natural e de explicá-lo. (DRIVER, R.; ASOKO, H.; LEACH, J.; MORTIMER, E. F.; SCOTT, P. Construindo conhecimento científico na sala de aula. Química Nova na Escola. São Paulo: SBQ. Trad. Mortimer. n. 9, 1999).

O que seria essa "introdução a uma forma de pensar sobre o mundo natural e explicálo?" Que movimentos, que processos constituem a construção dessa outra forma de pensar? Como é possível desenvolver isso nos alunos? Se aprender Ciência implica a elaboração de novas formas de pensar, o que implicaria o ensinar Ciência? Sobre isto, Candela (1995), uma pesquisadora mexicana, propõe que:

(...) a construção do conhecimento científico para professores e alunos implica, além de apropriar-se dos padrões temáticos (...) a apropriação dos recursos discursivos, das maneiras de falar, de argumentar, debater e legitimar esse conhecimento e em particular, os fatos científicos. (CANDELA, 1995, p. 15). 
Então se pode considerar que o discurso e a linguagem têm um papel importante em uma aula de Química, principalmente, como demonstrado nesta pesquisa, no Ensino de Química Analítica Qualitativa. Mas o que envolve estas relações na construção do conhecimento e do discurso são as evidências de que os discursos que circulam pela aula são fundamentais para a elaboração de uma certa forma de falar e pensar sobre o experimento, sobre o fenômeno, usando o raciocínio da Química.

Nas interações que ocorrem durante as aulas de Química Analítica Qualitativa, vários discurso estão circulando: os livros tidos como referenciais teóricos, do professor (seja na fala ou na lousa), dos colegas, dos fatos experimentais, do senso comum. Nesta perspectiva, considera-se, juntamente com a dos teóricos referenciados nesta pesquisa, que toda a compreensão é ativa, podendo-se dizer que, ao tentar atribuir sentido ao que está aprendendo, o aluno vai formular suas próprias "respostas", suas próprias maneiras de combinar aquilo que está sendo ensinado com o que já se sabia.

A pretensão desta pesquisa era estabelecer uma reflexão, através da análise dos registros em vídeo da argumentação dos alunos e sua relação com os conceitos de Química aplicados numa pesquisa de cátions e ânions, seja numa situação empírica ou teórica. Os resultados aqui obtidos apontam para uma necessária (re)significação do Ensino de Química Analítica Qualitativa como uma disciplina que proporciona ao estudante a possibilidade de interagir com fenômenos e sobre eles raciocinar, argumentar, intervir e desenvolver o pensamento reversível e antecipatório através da resolução de problemas, o que os leva ao período das operações formais levando estes estudantes a atingirem este estágio dos pressupostos da teoria de Piaget. Estas capacidades cognitivas desempenham um importante papel nas tomadas de decisão, sendo esta uma necessária competência e habilidade para o profissional em todos os setores da atividade produtiva, e não apenas naquelas ligadas diretamente à Química Analítica. 
A despeito do grande avanço quanto à modelagem molecular, a Química foi, é e continuará sendo uma ciência eminentemente experimental. Lastimavelmente, em grande parte dos cursos e das universidades, as práticas experimentais terminam por serem relegadas a um segundo plano, muitas vezes com cursos de natureza apenas teórica, ou melhor, livresca. (FARIAS, 2007).

Em qualquer disciplina que se baseia na observação dos fenômenos naturais, as práticas constituem-se ponto chave para uma verdadeira aprendizagem. A execução de atividades práticas em Química revela-se fundamental não apenas para que habilidades e competências sejam desenvolvidas, mas também para que o aluno possa apreciar a lógica, e, por que não dizer, a beleza envolvida na descoberta do conhecimento. Contudo, para que os conhecimentos possam ser efetivamente adquiridos, é fundamental que cada prática transforme-se em verdadeiros projetos de investigação científica, e não meramente na repetição mecânica de procedimentos experimentais, como normalmente se verifica. Certamente, a postura adotada pelo professor em muito contribuirá para o sucesso ou não desse objetivo. 


\section{REFERÊNCIAS}

ABREU, D. G. Uma proposta para o ensino da Química Analítica Qualitativa. Química Nova, São Paulo, v. 29, n. 06, nov. dez. 2006.

ALVIM, T. R. Perspectivas para o ensino da Química Analítica Qualitativa. Campinas: UNICAMP, 2005.

AMARAL, E. M. R.; MORTIMER, E. F. Uma metodologia para análise da dinâmica entre zonas de um perfil conceitual no discurso da sala de aula. In: SANTOS, F. M. T. $\underline{A}$ pesquisa em Ensino de Ciências no Brasil e suas metodologias. Ijuí: Ed. Unijuí, 2006.

ARAGÃO, Maria José. História da Química. Rio de Janeiro: Interciência, 2008.

ARANHA, Maria Lúcia de Arruda. Filosofando: introdução à filosofia. São Paulo: Ed. Moderna, 1986.

ATKINS, Peter. Princípios de química: questionando a vida moderna e o meio ambiente. Porto Alegre: Bookman, 2001.

BACCAN, N.; GODINHO, O. E. S.; ALEIXO, L. M.; STEIN, E. Introdução à semimicroanálise Quantitativa Elementar. 7. ed., Campinas: Editora da UNICAMP, 1997.

BACHELARD, G. A formação do espírito científico: contribuição para uma psicanálise do conhecimento. Tradução de Estela dos Santos Abreu. Rio de Janeiro: Contraponto, (1938), 1996.

BAUM, R. M. Henry Taube Wins ACS's Highest Award in Chemistry. Chem. Eng. News, $62,31,1984$.

BAKHTIN, M. M. Speech Genres \& Other Late Essays. Ed. by Caryl Emerson and Michael Holquist. Trans. by Vern W. McGee. Austin: University of Texas Press, 1986. 
BAKHTIN, M. M. Questões de literatura e estética. São Paulo: UNESP, 1993.

BAKHTIN, M. M. Os gêneros do discurso. In: Estética de criação verbal. Tradução de Maria Ermantina G. G. Pereira. São Paulo: Martins Fontes, 1953/2000.

CANDELA, A. A construção discursiva de contextos argumentativos no ensino de ciências. In: SALVADOR, C. C.; EDWARD, D. (Org.). Ensino, aprendizagem e discurso em sala de aula: aproximações ao estudo do discurso educacional. Porto Alegre: Artes Médicas, 1998.

CAPECCHI, M. C. V. M.; CARVALHO, A. M. P. Argumentação em uma sala de

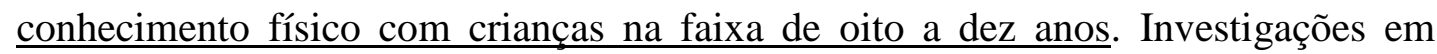
Ensino de Ciências. 〈http://www.if.ufrgs.br/public/ensino/vol5/n3/v5_n3_a2.htm>. Acessado em 31/07/2006.

CAPECCHI, M. C. V. M. Aspectos da cultura científica em atividades de experimentação nas aulas de Física. 2004. 264 f. Tese (Doutorado) - Faculdade de Educação, Universidade de São Paulo, São Paulo, 2004.

CARVAlHO, A. M. P. et alli. Ciência no Ensino Fundamental. Ed. Scipione. São Paulo: 1998.

CARVALHO, A. M. P. As explicações no ensino de Física. VII Encontro de Pesquisa em Ensino de Física, março 2000, Florianópolis.

CARVALHO, A. M. P. Uma metodologia de pesquisa para estudar os processos de ensino e aprendizagem em salas de aula. In: SANTOS, F. M. T. A pesquisa em Ensino de Ciências no Brasil e suas metodologias. Ijuí: Ed. Unijuí, 2006.

CASTORINA, José A. BAQUERO, Ricardo J. Dialética e psicologia do desenvolvimento: o pensamento de Piaget e Vygotsky. Porto Alegre: Artmed, 2008.

CHALMERS, F. A. ¿Qué es esa cosa llamada ciencia? Mexico: Siglo XXI, 1999. 
CHAMIZO, J. A. Antología de la enseñansa experimental. México: Facultad de Química UNAM, 2004.

CHAMIZO, J. A. Hacia una cultura química. Ciencia Revista de la Academia Mexicana de Ciencias, 56, p. 6-16, 2005.

CHAMIZO, J. A., IZQUIERDO, M. Avaliação das competências de pensamento científico. São Paulo: SBQ, Química Nova na Escola, 27, p. 4-8, 2008.

CHARAUDEAU, P.; MAINGUENEAU, D. Dicionário de Análise do Discurso. Tradução de Fabiana Komenesu. São Paulo: Contexto, 2005.

COLL, C.; GILLIÈRON. C. Jean Piaget: o desenvolvimento da inteligência e a construção do pensamento racional. In, LEITE, L. B. (Org.). Piaget e a Escola de Genebra. São Paulo: Cortez, 1987. p. 15-49.

CUVIER, G. Historie des Sciences naturelles depuis leurs origines jusqu'a nos jours. Paris, 1844,1845, p. 321).

DEWEY, J. How we think? A Restatement of the Relation of Reflective Thinking in the Educational Process. Chicago: Henry Regnery, 1933.

DEWEY, J. Expérience ete education. Paris: Armand Colin, (1947), 1993.

DRIVER, R.; NEWTON, P. Estabelecendo normas de argumentação Científica em Sala de Aula. Conferência ESERA. Roma, 1997.

DRIVER, R., NEWTON, P., OSBORNE, J. Establishing the norms of scientific argumentation in classrooms. Science Education, 84, p. 287-312, 2000.

DRIVER, R.; ASOKO, H.; LEACH, J.; MORTIMER, E. F.; SCOTT, P. Construindo conhecimento científico na sala de aula. Química Nova na Escola. São Paulo: SBQ. Trad. Mortimer. n. 9, 1999. 
DUSCHL, R. A. Research on the history and philosophy of science. In. Gabel, D. (Ed.). Handbook of research on science teaching and learning. New York: MacMillan, 1994, p. 445-455.

ECHEVERRIA, A. Como os estudantes concebem a formação de soluções. Química Nova na Escola, n. 3, 1996.

ENGELS, F. A dialética da natureza. Rio de Janeiro: Ed. Paz na Terra, 1979.

FACHINI, Assesio Jr. Utilização do estágio supervisionado como ferramenta diferenciada na Prática de Ensino de Química. In: XII Encontro Nacional de Ensino de Química, 2004, Goiânia. Anais do Encontro, trabalho número 268. Goiânia: 2004.

FARIA, Anália Rodrigues de. $\underline{\mathrm{O} \text { desenvolvimento da criança e do adolescente segundo Piaget. }}$ São Paulo: Ed. Ática, 1998.

FARIAS, R. F. Práticas de Química Inorgânica.Campinas: Ed. Átomo, 2007.

FREISER, H. Why Teach Qualitative Analysis. J. Chem. Educ., 34, 387, 1957.

FURTADO, O.; BOCK, A. M. B; TEIXEIRA, M. L. T. Psicologias: uma introdução ao estudo de psicologia. 13.ed. São Paulo: Saraiva, 1999.

GIL-PEREZ, D. et alii. ¿Tiene sentido seguir distinguiendo entre a aprendizaje de conceptos, resolución de problemas de lápiz y papel y realización de prácticas de laboratorio? Enseñanza de las Ciencias. Barcelona, 1999, 17 (2), p. 311-320.

GIL, D. Pérez. et alii. Para uma imagem não deformada do trabalho científico. Ciência \& Educação. São Paulo: Ed. ABEC, 2001, v. 7, n², p. 125-153.

GOGUELIN, P. Dossier projet. Revue des Sciences Humaines. Lille, n.39, p.31, maio 1994.

GUSNSTONE, R. F., NORTHIFIELD, J. Conceptual change in teacher education: the centrality of metacognition. Symposium conceptual change approaches in teacher education at meeting. American Education Research Association. San Francisco, 1992. 
ISQUIERDO, M. El naixement de la Química Moderna. Revista de la Societat Catalana de Química, 2, p. 43-48, 2001.

JENSEN, W. Does chemistry have a logical structure. Journal of Chemical Education, 75, p. 679-687, 1998.

KUHN, T. The structure of scientific revolutions. Chicago: University of Chicago Press, 1970.

KUHN, D. Science as Argument: Implications for teaching and Learning Scientific thinking. Science Education. 1993.

LAITINEN, H. A. Analytical Chemistry in a Changing World. Anal. Chem., 52, 605A, 1980.

LA TAILLE., Y. Prefácio. In, PIAGET, J. A construção do real na criança. 3.ed. São Paulo: Editora Ática, 2003.

LAUDAN, H. Progress and its problems. Berkley: University of California, 1977.

LEACH, J. T.; SCOTT, P. H. (2002) The concept of learning demand and approaches to designing and evaluating science teaching sequences. Studies in Science Education, February 2002.

LEITE, Flávio. Práticas de Química Analítica. Campinas: Ed. Átomo, 2008.

LEMKE, J. Teaching all the languages of Science: works, symbols, images and actions. Barcelona: Metatemas, 2003.

LÜDKE, M.; ANDRÉ, M. E. D. A. Pesquisa em Educação: Abordagens Qualitativas. São Paulo: EPU, 1986.

McCLELLAN, A. L. Guia do professor para Química: uma ciência experimental. Lisboa: Fundação Calouste Gulbenkian, 1984. Páginas 45 a 55.

MATHIAS, S. Cem anos de Química no Brasil. O Estado de São Paulo, São Paulo, 8/2/1975. MELLO, Ary Ferraz de. Introdução à Análise Mineral Qualitativa. São Paulo: Pioneira, 1977. 
MELO, T. M. M. A conjugação teoria/prática na sala de aula. Linguagem \& Ensino, vol.5, n01, p.149-169, 2002.

MIZUKAMI, M. G. N. Ensino: as abordagens do processo. São Paulo: EPU, 1986.

MORTIMER, E. F.; MACHADO, A. H. Múltiplos olhares sobre um episódio de Ensino: "Porque o gelo flutua na água? Encontro sobre teoria e pesquisa em Ensino de Ciência. Belo Horizonte, 1997.

MORTIMER, E. F. (1998). Multivoicedness and univocality in classroom discourse: an example from theory of matter. International Journal of Science Education, (1): 6782. 1998.

MORTIMER, E. F. (2000). Microgenetic analysis and the dynamic of explanation in science classrooms. Proceedings of the III Conference for Sociocultural Research, http://www.fae.unicamp.br/br2000. 2000.

MORTIMER, E. F.; SCOTT, P. H. Atividade discursiva nas salas de aula de ciências: uma ferramenta sociocultural para analisar e planejar o ensino. Investigações em Ensino de Ciências, Porto Alegre, v.7, n.3, 2002.

MORTIMER, E. F., MACHADO, A. H. Química para o Ensino Médio: Volume Único. São Paulo: Scipione, 2002.

MORTIMER, E. F., MACHADO, A. H. Química para o Ensino Médio: Volume Único. Assessoria Pedagógica. São Paulo: Scipione, 2003.

MORTIMER, E. F.; SCOTT, P. H. Meaning making in secondary science classrooms. Maidenhead: Open University Press, 2003.

MORTIMER, E. F.; MASSICAME, T.; TIBERGHIEN, A.; BUTY, C. Uma metodologia para caracterizar os gêneros do discurso como tipos de estratégias enunciativas nas aulas de Ciências. In: NARDI, R., (org). A pesquisa em Ensino de Ciências no Brasil: alguns recortes. São Paulo: Escrituras, 2007. 
NEVES, Luiz Seixas das. História da Química: um livro texto para a graduação. Campinas: Ed. Átomo, 2008.

NÓVOA, A. O professor se forma na Escola. In: Escola Pública e Sociedade. São Paulo: Saraiva/Atual, 2002.

OLIVEIRA, M. K. Vygotsky: aprendizado e desenvolvimento, um processo sócio-histórico. São Paulo: Scipione, 1999.

OLIVEIRA, M. K. de. Letramento, cultura e modalidades de pensamento. In: KLEIMAN, A. B., (org.). Os significados do letramento. Campinas: Mercado das Letras, 2001. p.147-160.

PERRENOUD, Philippe. A prática reflexiva no ofício de professor. Porto Alegre: Artmed, 2002.

PERUZZO, Francisco Miragaia. Química na abordagem do cotidiano. São Paulo: Moderna, 2006.

PIAGET, J. O raciocínio da criança. São Paulo: Ed. Record, 1967.

PIAGET, J.; INHELDER, B. Gênese das estruturas lógicas elementares. Tradução de Álvaro Cabral. Rio de Janeiro: Zahar Editores, 1975.

PIAGET, J. Seis estudos de psicologia. Editora Forense, 1977.

PIAGET, J. A formação do símbolo na criança: imitação, jogo e sonho, imagem e representação. Rio de Janeiro: LTC, 1990.

PIAGET, J. Psicologia e epistemologia. Lisboa: Dom Quixote, 1991.

POINCARÉ, H. O valor da ciência. Rio de Janeiro: Contraponto, 2000.

RAPPAPORT, C. R. Modelo piagetiano. In RAPPAPORT; FIORI; DAVIS. Teorias do Desenvolvimento: conceitos fundamentais - Vol. 1. EPU, 1981, p. 51-75. 
REIGOSA CASTRO, C. E.; JIMÉNEZ ALEIXANDRE, M. P. La cultura cientifica em la resolución de problemas em el laboratório. Enseñanza de las Ciencias, 18(2), 175$284,2000$.

RHEINBOLDT, H. Orientação do Ensino da Química. Separata do Anuário da Faculdade de Filosofia, Ciências e Letras, 1935.

RIOS, Therezinha Azeredo. Compreender e ensinar: por uma docência de melhor qualidade. São Paulo: Cortez, 2001.

ROJO, R. Gêneros do discurso e gêneros textuais: questões teóricas e aplicadas. In: Gêneros: teorias, métodos e debates. São Paulo: Parábola, 2005, p. 184-207.

ROTH, W. M. Authentic science: Enculturation into the conceptual blind spots of a discipline. American Education Research Association. Montréal, 1999.

SCERRI, E. R. Philosophy of chemistry - a new interdisciplinary field? Journal of Chemical Education, 77, p. 522-525, 2001.

SCHÖN, D. Le praticien réfexif. À la recherche du savoir caché dans lágir porofessionnel. Montréal : Ed. Logiques, 1994.

SENISE, P. E. A. A formação do Químico. Química Nova, São Paulo, 1982, 5, 137.

SILVA, Luciana Almeida. Por que os nitratos são todos solúveis? Química Nova, São Paulo, v. 27, n. 06, nov. dez. 2004.

STRONG, F. C. The Qualitative Analyses in the General Chemistry Program. J. Chem. Educ., 34, 400, 1957.

SWIFT, E. H. A proposal for a Reversal of Trends. J. Chem. Educ., 27, 677, 1950.

TIBERGHIEN, A. Modeling as a basis for analyzing teaching-learning situations. Learning and instruction, v.4, n.1, p. 71-87, 1994.

TOULMIN, S. The uses of argument. Cambridge University Press, 1958.

TOULMIN, S. Human understanding. Princeton: Princeton University Press, 2004. 
USBERCO, João. Química: Volume Único. $5^{\text {a }}$ ed. Refor. São Paulo: Saraiva, 2002.

VOGEL, A. I. Química Analítica Qualitativa. São Paulo: Mestre Jou, 1981.

VYGOTSKY, L. S. A construção do pensamento e da linguagem. Tradução de Paulo Bezerra. São Paulo: Martins Fontes, (1934) 2001.

WASLEY, W. L. The Objectives of Qualitative Analyses. J. Chem. Educ., 23, 357, 1946.

WOOD, D. J.; BRUNER, J. S.; ROSS, G. (1976). The role of tutoring in problem solving. Journal of Psychology and Psychiatry, (17), pp. 89-100.

WERTSCH, J. V. Voices of the mind: A sociocultural approach to mediated action. Harvester Wheatsheaf. 1991.

YDI, Simone Jaconetti; LISBOA, Julio C. Fosquini. Uma proposta para o desenvolvimento integrado das disciplinas de Química Analítica Qualitativa e Química Inorgânica fundamentado em projetos e valores - o papel do aluno e do professor. $\underline{\text { Revista }}$ Fundação Santo André, Santo André, n 2, p. 97-110, 2003.

ZUCCO, C; PESSINE, F. B. T.; ANDRADE, J. B. Diretrizes Curriculares para os cursos de Química. Química Nova. São Paulo, v. 22, n. 3, p. 454-461, 1999. 


\begin{abstract}
ANEXOS
Anexo 1 - Transcrição integral das aulas experimentais de Química Analítica Qualitativa

Para a transcrição das aulas utilizou-se como referência os trabalhos de Capecchi (2004) bem como as recomendações de Carvalho (2006), apresentada no artigo "Uma metodologia de pesquisa para estudar os processos de ensino e aprendizagem em salas de aula".
\end{abstract}

A transcrição foi organizada num quadro com três colunas: a primeira indica o tempo registrado pela própria filmagem que auxilia na busca do episódio para posterior consulta no DVD; a segunda coluna transcreve a fala na íntegra, sendo mantido o vocabulário, construção gramatical da frase, bem como concordância ou outras expressões e o proponente do argumento é identificado nominalmente e o professor/pesquisador identificado com a letra "P"; já na terceira coluna descrevem-se os comentários contextuais como gestos, situações comportamentais que auxiliam no entendimento do ambiente em que ocorre a argumentação.

Toda a coleta de imagens perfaz aproximadamente 140 minutos ( $2 \mathrm{~h} 20 \mathrm{~min})$ que foram coletadas em 4 dias de atividades com os alunos para criar um ambiente propício para que a argumentação fosse estabelecida (como já discutido no item 2.3). Os episódios foram organizados de acordo com a interação que havia entre os alunos e o professor/pesquisador que era chamado para auxiliar em alguma questão conceitual ou ora apenas aproximava-se do grupo para iniciar uma relação dialógica.

A imagens e o estudo da argumentação foi realizado com 18 alunos, sendo os registros feitos aleatoriamente a medida que os alunos chamavam o professor ou que se percebia uma interação dialógica interessante entre eles. Certamente muitas outras interações ocorrem mas 
não foram registradas, sendo estes argumentos uma amostra das relações argumentativas que se estabelecem numa aula de Química Analítica Qualitativa.

Os alunos que participaram desta pesquisa foram: Adriana Sampaio de Brito, Andrews Soares dos Santos Alves, Ângela Seles, Arlindo Lopes de Lima, Claudinei Batista de Souza, Diógenes Genari de Lima, Edvard Ramos Medeiros, Débora Mizue Kimoto, Evandro Silva Soares, Fábio Fere Felipe, Fernando Mendes de Lima, Flávio Cezar Martins, Luciana Lunardi Bustos, Rafael Ribeiro de Araújo, Renato Lopes da Silva, Ronaldo Denalussi Mazaia, Thiago Baldin Lopes e Wendel de Oliveira.

\section{1}

Episódio 1: Explanação geral de orientação a respeito da atividade experimental

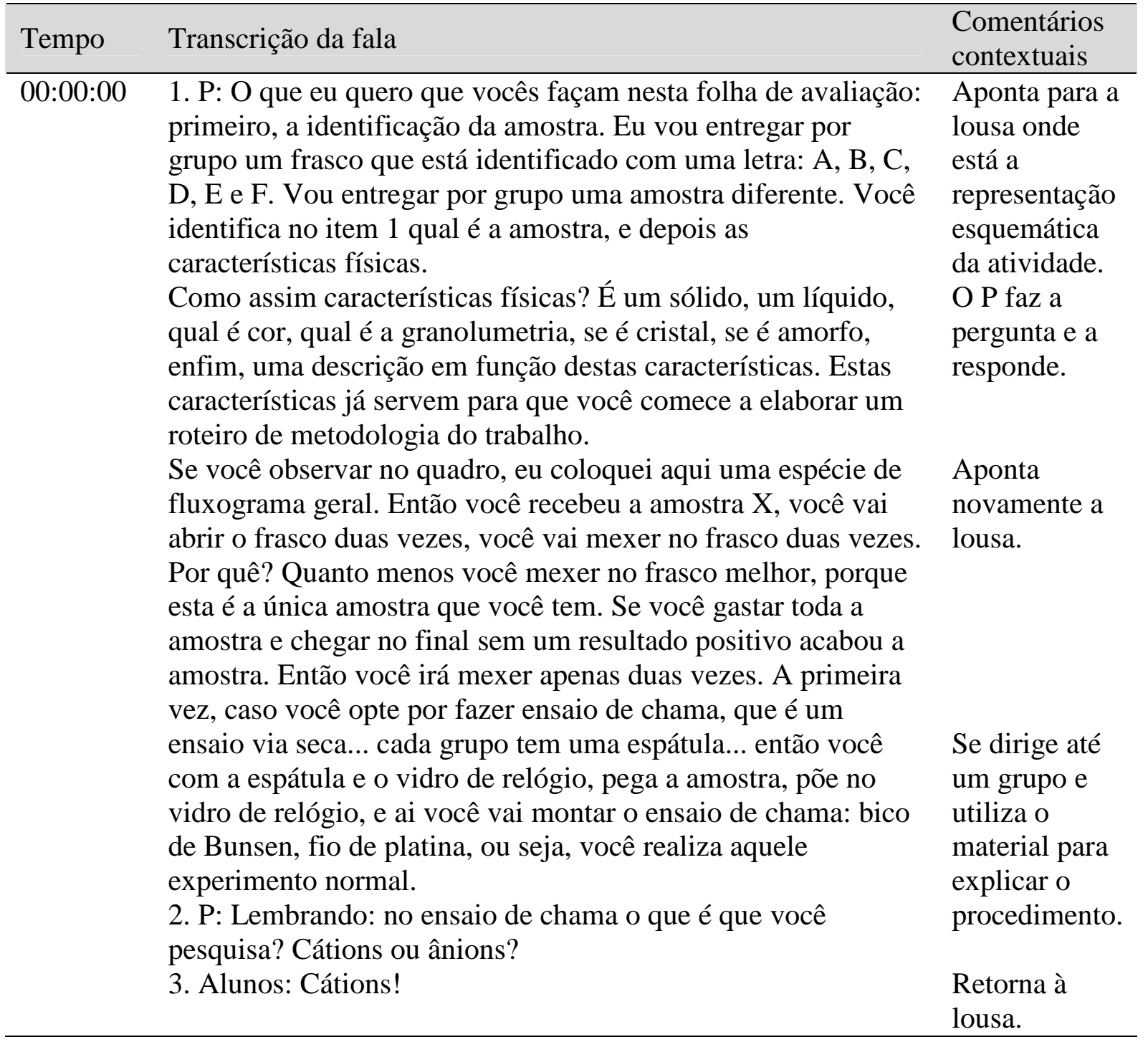




\begin{tabular}{ll}
\hline 00:02:34 & 4. P: Mas eu pesquiso todos os cátions? \\
& 5: Alunos: Não! \\
& 6: P: Então se você for nas suas anotações... quem tem ai o \\
roteiro que tem o espectro? As cores dos espectros no ensaio \\
de chama? Aqui! Aqui, este aqui! \\
7: P: Pessoal! Neste roteiro, o que você tem? As cores que \\
cada elemento químico produz na chama e quais são os \\
comprimentos de onda. Portanto, você tem alguns cátions que \\
dão cor na chama. Talvez o cátion que você esteja procurando \\
não emita cor na chama. Não tem problema nenhum. Você \\
chegou a conclusão que o cátion da sua amostra não é nenhum \\
desses. Portanto já os eliminou.
\end{tabular}

00:03:41 8. P: Então você agora passa para o procedimento que você adotou. Neste procedimento você mexe na amostra novamente, abre a amostra e faça então uma solução mãe. O que você vai testar? Amostra mais água. O primeiro teste que você faz: a amostra é solúvel ou não é solúvel em água? É a primeira característica. Se ela é solúvel, esta solução conduz corrente elétrica ou não conduz corrente elétrica? Conduz muito ou conduz pouco? Então se você quiser usar o condutivímetro tudo bem, pode utilizá-lo, é uma opção do grupo.

9. P: Da amostra mãe, por isso eu deixei aqui uma pipeta de Pasteur, você deixa aqui no Becker a pipeta de Pasteur, pega uma alíquota da amostra e faça a primeiro teste. Olha, vou testar a amostra com o ácido. Opa, não aconteceu nada. Quero testar a amostra com um indicador. Opa, aconteceu hidrólise. Quero testar a amostra... por exemplo... com carbonato. Opa, formou um precipitado branco. Você vai começar a juntar estas evidências para fazer a sua pesquisa de cátions e ânions.

00:04:53 10. P: Quando você juntar estas prováveis idéias de qual é o cátion e qual é o ânion você vai tirar uma conclusão baseada nas evidências. Portanto o seu cátion é um metal, o X de não metal, ou um metal e um não metal oxigenado. Então você tem estas evidências que te levarão a esta conclusão. Certo?

00:05:13 11: P: Recomendações: este deve ser um trabalho feito em equipe. Portanto, se cada um começar a fazer espontaneamente aquilo que acha que vai dar certo, por experiência própria, no final da aula vocês não vão chegar a resultado nenhum. Então a equipe deve decidir: vamos fazer tal análise. Faça a análise e discuta com o grupo. Deu certo? Não deu certo? Porque que aconteceu? Porque não aconteceu? Tome essa decisão com o grupo. A partir do momento em que vocês tomaram essa decisão passam para a próxima, porque se vocês começarem a misturar informações, daqui a pouco não sai mais nada. Está ok?
A maioria

responde.

Anda pelo laboratório para encontrar o papel.

Segurando o papel.

Aponta para a papel.

Fala apontado para 0 esquema desenhado na lousa.

Aponta para a representação na lousa do resultado que é MX ou MXO

Gesticula e fala olhando para todos os alunos 
Episódio 2: Argumentação durante a entrega da amostra para os grupos

\begin{tabular}{lll}
\hline Tempo & Transcrição da fala & $\begin{array}{c}\text { Comentários } \\
\text { contextuais }\end{array}$ \\
\hline 00:06:18 & $\begin{array}{l}\text { 13. P: Vocês já pegaram a amostra? } \\
\text { 14. Ronaldo: Não! }\end{array}$ & \\
& 15. P: Então toma. Pegue esta. \\
& 16. Rafael: Agora sim! \\
00:06:21 & 17. Débora: Mas só isto professor? \\
& $\begin{array}{l}\text { 18. Ronaldo: Não é muito não? ... [fala num tom sarcástico]... } \\
\text { 19. P: Volta nas anotações de aula e veja qual é o conceito de } \\
\text { análise... [pausa]... Macroanálise, microanálise e } \\
\text { ultramicroanálise. A macroanálise é feita com meio a um } \\
\text { grama de amostra. Então tem amostra mais do que suficiente } \\
\text { ai. }\end{array}$ \\
\hline
\end{tabular}

Episódio 4: Argumentação a respeito da abertura da amostra em água

\begin{tabular}{lll}
\hline Tempo & Transcrição da fala & $\begin{array}{c}\text { Comentários } \\
\text { contextuais }\end{array}$ \\
\hline 00:11:30 & 20. Thiago: Peguei a amostra, coloquei no Becker, adicionei & \\
& 20 mL de água e ficou completamente solúvel. \\
& 21. P: Então a amostra é solúvel em água? \\
& 22. Marcelo: Sim, é totalmente solúvel em água. \\
& 23. P: Então o que você faz? Cadê aquela tabelinha de \\
& solubilidade? \\
24. Thiago: Então eu posso ir lá... [aponta para o \\
condutivímetro]... e ver se conduz corrente elétrica. \\
25. P: Pode! \\
26. P: Então, pela tabela você já separa quem é solúvel em \\
água. Você já tem um caminho a seguir, analisando somente \\
aquelas que são solúveis. \\
27. P: Aqui vocês podem fazer uma amostra maior. Coloque \\
mais amostra e mais água. Mas não deixe a espátula dentro do \\
Becker. Se a sua amostra for ácida ou básica ela vai atacar a \\
espátula. Ácidos e bases não atacam metal? \\
28. Thiago: ...[confirma com a cabeça]... \\
29. P: A espátula não é de metal? Então vai haver uma reação \\
contaminando sua amostra mãe.
\end{tabular}

Episódio 5: Argumentação a respeito da interpretação dos resultados obtidos

\begin{tabular}{lll}
\hline Tempo & Transcrição da fala & $\begin{array}{l}\text { Comentários } \\
\text { contextuais }\end{array}$ \\
\hline 00:00:00 & $\begin{array}{l}\text { 30. Flávio: Professor? Sabe o que eu não consigo colocar na } \\
\text { cabeça? }\end{array}$ & \\
& $\begin{array}{l}\text { 31. P: O quê? } \\
\text { 32. Flávio: Como eu consigo, na explicação teórica, estava } \\
\text { batendo tudo, acho que eu até falei demais, mas aqui eu não } \\
\text { consigo intercalar as coisas... ligar as informações [pausa] para }\end{array}$ & $\begin{array}{l}\text { Fala olhando } \\
\text { para as } \\
\text { anotações. }\end{array}$ \\
\hline
\end{tabular}


chegar numa conclusão. Acho que tem muita coisa aqui que dá Entrelaça os para eu chegar a algum lugar.

dedos num

gesto de

junção.

00:00:20 33. P: Dá. Você precisa juntar quais foram as evidências ocorridas... [o aluno interrompe o professor]...

34. Flávio: É esse juntar que eu não consigo...

Fala

35. P: [o P continua a fala] ...para poder justificar. Olha, vamos juntar coisas aqui.

sorrindo.

$P$ pega lápis

e papel.

00:00:32 36. P: Olha: no ensaio de chama, deu amarelo, que é o sódio.

Fala

37. Flávio: Isso.

enquanto

38. P: Então você tem uma possibilidade. Não dá para bater o

escreve.

martelo e dizer que é o sódio.

39. Flávio: Isso.

40. P: Agora, no ânion. É alguma coisa de sódio. Agora, vamos ver quais foram as evidências daquilo que você já fez.

O P faz a leitura das anotações do aluno.

P movimenta a mão sobre o papel.

41. P: Ao colocar o $\mathrm{HCl}$ formou um precipitado branco? É

00:00:53 isso?

42. Flávio: Sim, formou.

43. P: Então significa que se você adicionou $\mathrm{HCl}$, significa que o cloreto reagiu com o sódio?!

44. Flávio: Então para eu me certificar que... [pausa]... mas

00:01:15 aqui...

45. P: Mas ai é que está. Agora veja: quando você colocou aqui, olha, $\mathrm{HCl}$, portanto, o que veio daqui? Veio o cloreto. Cloreto é o reagente de grupo. Cloreto não reage com o sódio! 46. Flávio: Não reage?!

47. P: Não reage!

00:01:32 48. P: Então, ao adicionar o cloreto, formou um precipitado branco. Agora, vamos continuar, o que mais você colocou? 49. P: Cloreto formou um precipitado branco. O iodeto: quando você colocou o iodeto formou um precipitado branco também?

50. Flávio: ... [silêncio] ...

51. P: Iodeto não reage com o sódio.

P lê a frase

escrita questionando o aluno.

Retoma a escrita no papel.

Retoma a leitura das anotações.

$\mathrm{P}$ volta a escrever no

52. Flávio: Não reage! papel. Confirma o

00:02:02 53. P: Não reage. Ai você colocou aqui de novo... cloreto... [ $o$ aluno interrompe o $P]$...

54. Flávio: Como que fala quando precipita? O que precipita não é o que fica no fundo? que o $\mathrm{P}$ disse.

O aluno gesticula 
55. P: Isso!

56. Flávio: E aqui, a amostra ficou branca, ficou tipo leite.

00:02:22 57. P: Então a sua amostra não dissolveu na água?

58. Flávio: Não!

com a mão

puxando para

baixo.

59. P: Então sua amostra é insolúvel. Por isso existe sempre

P confirma

com a

cabeça. um precipitado antes mesmo de você adicionar o reagente.

Episódio 6: Argumentação a respeito da hidrólise provocada pela amostra

\begin{tabular}{ll}
\hline Tempo & Transcrição da fala \\
\hline 00:35:10 & $\begin{array}{l}\text { 60. P: Por que eu acho que a sua amostra deve formar uma } \\
\text { solução ou muito ácida ou muito básica? Por que quando você } \\
\text { fez o ensaio de chama e colocou a amostra no vidro de relógio, } \\
\text { olha o que aconteceu... [mostra o vidro de relógio usado no } \\
\text { ensaio]. Ela atacou a espátula. Com certeza ela deve ser muito } \\
\text { ácida ou muito básica. }\end{array}$ \\
$\begin{array}{l}\text { 61. P: Vamos usar indicadores. Por exemplo, azul de } \\
\text { bromotimol. Se mudar de cor... toda mudança de cor é porque } \\
\text { é ácido ou básico... então faça este teste. }\end{array}$ \\
O aluno adiciona no tubo de ensaio com a amostra o indicador \\
azul de bromotimol que fica amarelo.
\end{tabular}

Comentários

contextuais

Pega vidro de relógio e a espátula usada.

00:36:05 62. P: Está ácido. Portanto a sua amostra, quando dissolvida em água, provoca uma hidrólise ácida.

63. P: Agora pensa: quais são os cátions, que quando dissolvidos na água provocam hidrólise ácida? Entendeu a idéia?

64. P: Agora veja: primeira coisa provoca hidrólise ácida. No ensaio de chama não provoca mudança de cor. Portanto, não é nenhum destes aqui...

Fala apontando para o papel onde estão anotados os resultados do grupo.

$00: 36: 31$

65. P: O que pode ser?

66. Edvard: É então cloreto de sódio?

67. P: O sódio provoca cor amarela... [aponta para a tabela de cores dos espectros luminosos]. Não pode ser o sódio.

68. P: Cloreto de sódio provoca hidrólise?

00:36:44 69. Edvard: ... [inicia uma argumentação, mas permanece em silêncio, então responde...] Não!

70. P: Não! 
Episódio 7: Argumentação a respeito da condutividade elétrica da solução

\begin{tabular}{lll}
\hline Tempo & Transcrição da fala & $\begin{array}{c}\text { Comentários } \\
\text { contextuais }\end{array}$ \\
\hline 00:37:04 & 71. P: Então você colocou um pouco de HCl na amostra? & \\
& 72. Evandro: Sim. \\
& 73. P: Então a condutividade não é por causa da amostra, é por \\
& causa do ácido. \\
& 74. Evandro: Mas eu dissolvi a amostra antes em água. \\
& 75. Anderson: E antes de colocar o ácido nós testamos a \\
& condutividade. \\
& 76. P: Ai sim! Se você misturou a amostra na água, a água não \\
& conduz, mas quando você colocou a amostra conduziu? \\
& 77. Evandro: Sim, conduziu. \\
& 78. P: Então significa que a água e a amostra produzem uma \\
& solução condutora? \\
& 79. Evandro: ... [expressa confirmação com a cabeça]... \\
& 80. P: Ai tudo bem!
\end{tabular}

Episódio 8: Argumentação sobre a interpretação do resultado da análise

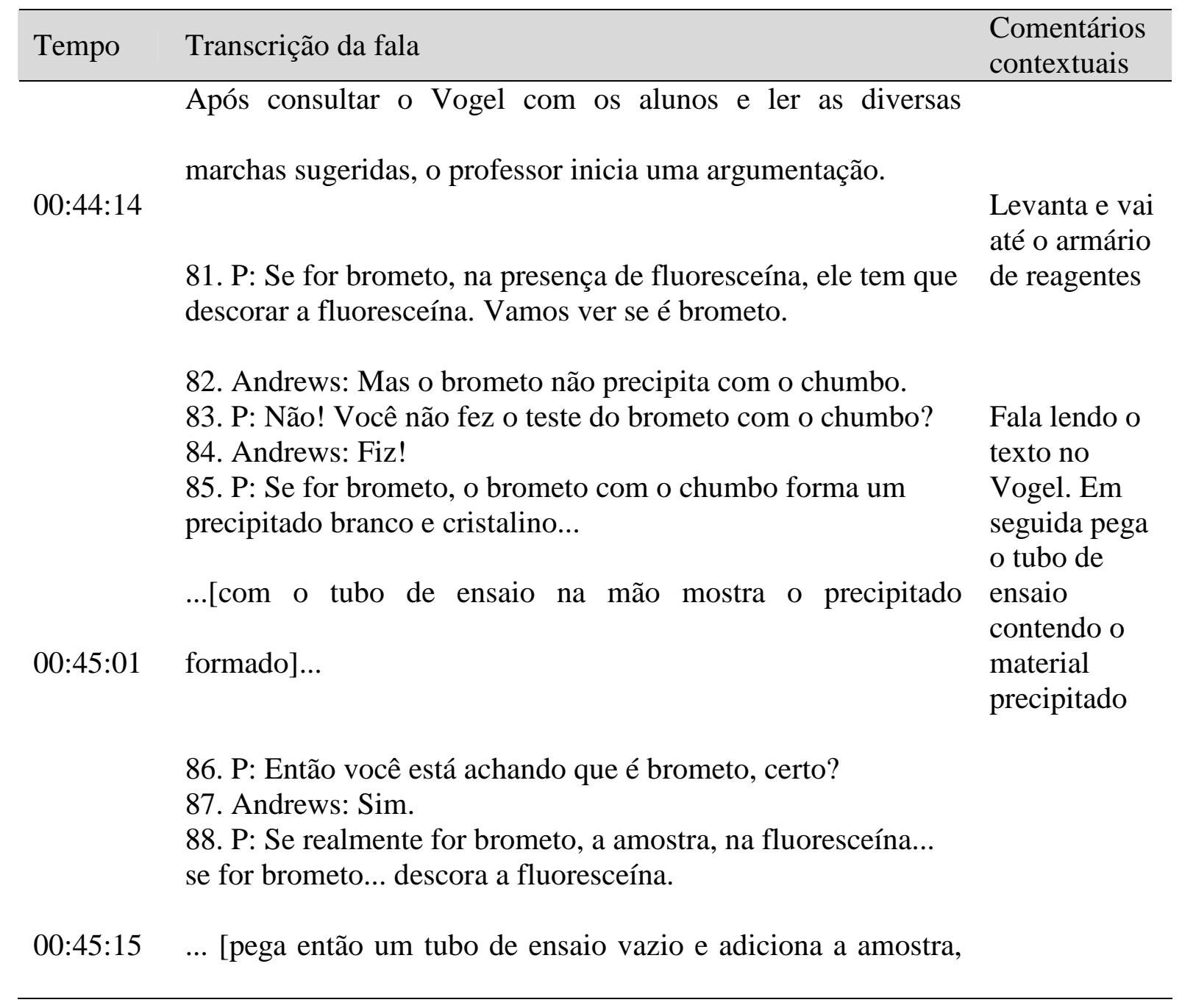


em seguida goteja a fluoresceína]...

89. P: Está vendo? Não houve reação. Sua amostra não é

brometo. É algum ânion que reage com o chumbo, mas não é

brometo.

Episódio 9: Argumentação sobre a interpretação das cores no ensaio de chama

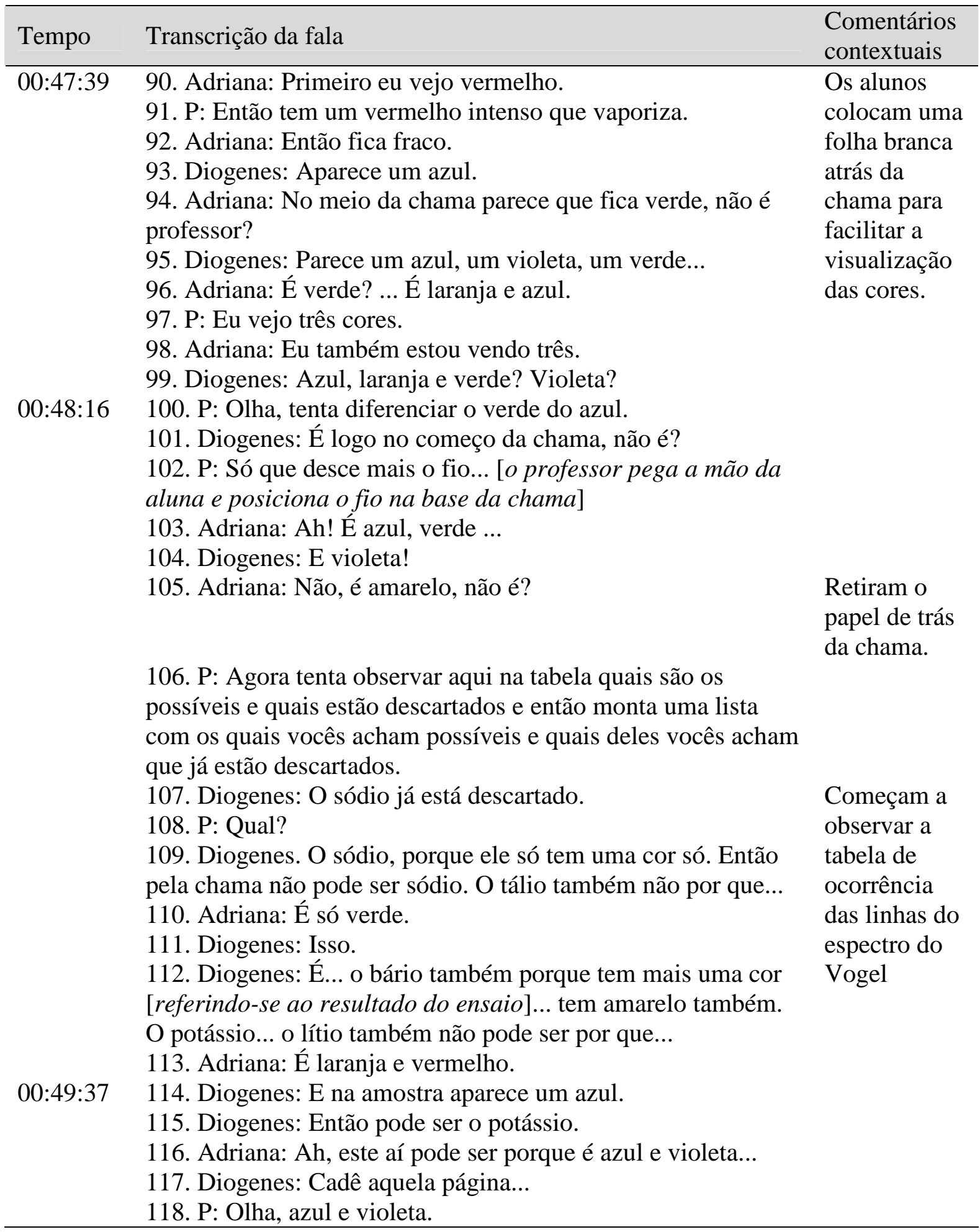


119. Adriana: São bem próximos... e o verde também.

120. P: Na sua opinião pode ser qual?

00:49:52 121. Diogenes: Pode ser o potássio... ou o estrôncio... cálcio... laranja, verde amarelada violeta fraca. 122. Adriana: Ah! Pode ser esta!

Episódio 10: Argumentação sobre a sequiência da marcha analítica realizada

\begin{tabular}{|c|c|c|}
\hline Tempo & Transcrição da fala & $\begin{array}{l}\text { Comentários } \\
\text { contextuais }\end{array}$ \\
\hline $00: 50: 28$ & $\begin{array}{l}\text { 123. P: O que vocês fizeram? } \\
\text { 124. Thiago: A gente fez o ensaio de chama. A chama ficou } \\
\text { vermelha e dentro da vermelhidão da chama a gente acha que } \\
\text { pode ser potássio e pode ser lítio... cadê o tal do lítio? } \\
\text { 125. P: Ok! } \\
\text { 126. Thiago: Ai nós fizemos a solução mãe, ai em cima disto } \\
\text { nós colocamos um pouquinho em cada tubo de ensaio, neste } \\
\text { nós colocamos azul de bromotimol, neste nós colocamos } \\
\text { fenolftaleína e aqui... } \\
\text { 127. P: Alaranjado de metila. } \\
\text { 128. Thiago: Isso! E o único que reagiu foi o alaranjado de } \\
\text { metila. } \\
\text { 129. P: Então vocês estão testando hidrólise? } \\
\text { 130. Thiago: Isso! } \\
\text { 131. Fabio: Então houve uma hidrólise ácida. } \\
\text { 132: P: Ocorreu então uma hidrólise ácida? } \\
\text { 133. P: Se é uma hidrólise ácida... } \\
\text { 134. Thiago: Olha, se você olhar neste aqui eu coloque } \\
\text { bastante... [fala apontado para o tubo de ensaio contendo } \\
\text { fenolftaleína que está levemente rosado]... e você pode ver que } \\
\text { ele reagiu um pouco. } \\
\text { 135. P: Então, mas se aqui é fenolfataleína... fenolftaleína fica } \\
\text { que cor em meio ácido? } \\
\text { 136. Thiago: Rosa, vermelho... dependendo da concentração. } \\
\text { 138. P: Então espera ai. Vamos fazer uma diferenciação: a } \\
\text { fenolftaleína em meio ácido fica... } \\
\text { 139. Thiago: Porque lá na firma, quando a gente vai medir a } \\
\text { acidez da resina a gente usa fenolfaleína. } \\
\text { 140. Fabio: Em meio ácido ela é incolor. }\end{array}$ & $\begin{array}{l}\text { Fala } \\
\text { apontando } \\
\text { para a tabela } \\
\text { de ocorrência } \\
\text { das linhas do } \\
\text { espectro do } \\
\text { Vogel }\end{array}$ \\
\hline $00: 52: 02$ & $\begin{array}{l}\text { 141. P: Isso, em meio ácido é incolor. Em meio básico? } \\
\text { 142. Fabio: Fica rosa ou .... vermelho... } \\
\text { 143. P: E esta aqui está ficando?... } \\
\text { 144. Thiago: Rosa! } \\
\text { 145. P: Então o meio está mais para o quê? } \\
\text { 146. Fabio: Para básico do que ácido. } \\
\text { 147. P: Qual o objetivo de fazer este teste para hidrólise? }\end{array}$ & \\
\hline $00: 52: 19$ & $\begin{array}{l}\text { 148. Fabio: É... pra ver o ânion... o comportamento do ânion... } \\
\text { seguir um... [gesticula] } \\
\text { 149. P: Então você quer testar se o teu material veio de um } \\
\text { ácido fraco ou de um ácido forte, ou de uma base fraca ou de }\end{array}$ & $\begin{array}{l}\text { Fala com as } \\
\text { mãos, } \\
\text { apontando } \\
\text { uma direção }\end{array}$ \\
\hline
\end{tabular}




\begin{tabular}{|c|c|c|}
\hline $00: 52: 54$ & $\begin{array}{l}\text { uma base forte? } \\
\text { 150. Fabio: ... [responde gesticulando com a cabeça]... } \\
\text { 151. P: Então se isto for verdade tem hidrólise? Mas tem uma } \\
\text { hidrólise evidente aqui ou está meio mascarado? } \\
\text { 152. Fabio: Está meio mascarado. } \\
\text { 153. P: Então que conclusão você chega? Este material } \\
\text { provoca ou não hidrólise? }\end{array}$ & $\begin{array}{l}\text { Aponta para } \\
\text { os tubos de } \\
\text { ensaio }\end{array}$ \\
\hline & ... [silêncio $]. .$. & \\
\hline $00: 52: 58$ & $\begin{array}{l}\text { 154. Thiago: Eu acho que provoca. } \\
\text { 155. Fabio: Não provoca. } \\
\text { 156. P: Olha, por estas evidências aqui... eu acho que se } \\
\text { provoca... não provoca ou provoca uma leve hidrólise. } \\
\text { 157. Thiago: Mas quase pra nada. } \\
\text { 158. P: Então com certeza deve ser um cátion de uma base } \\
\text { forte e um ânion de um ácido forte. Concorda? }\end{array}$ & \\
\hline
\end{tabular}

Episódio 11: Argumentação sobre a sequiência da marcha analítica realizada

\begin{tabular}{|c|c|c|}
\hline Tempo & Transcrição da fala & $\begin{array}{l}\text { Comentários } \\
\text { contextuais }\end{array}$ \\
\hline $00: 53: 53$ & $\begin{array}{l}\text { 159. Fernando: Eu coloquei o reagente e ficou uma parte em } \\
\text { cima boiando e o resto afundou. } \\
\text { 160. P: Então você pegou a sua amostra e colocou nitrato de } \\
\text { prata e então formou um precipitado branco? } \\
\text { 161. Fernando: Isso! } \\
\text { 162. P: E isto te leva a que conclusão? } \\
\text { 163. Fernando: Então professor, estou olhando aqui no livro do } \\
\text { Vogel e não estou conseguindo identificar... }\end{array}$ & $\begin{array}{l}\text { Fala } \\
\text { mostrando o } \\
\text { tubo de } \\
\text { ensaio } \\
\text { contendo a } \\
\text { amostra } \\
\text { reagida }\end{array}$ \\
\hline $00: 54: 23$ & $\begin{array}{l}\text { 164. P: Então significa que o teu... vamos tentar organizar } \\
\text { aqui... você pegou a amostra... você pegou a prata... é um } \\
\text { cátion ou um ânion? } \\
\text { 165. Fernando: É um cátion. } \\
\text { 166. P: Isso! É um cátion. Então você vai reagir com o ânion } \\
\text { da amostra. Então se você reagiu com o ânion da amostra } \\
\text { formou um precipitado... formou alguma coisa de prata. Então } \\
\text { quais são os ânions que reagem com a prata? }\end{array}$ & $\begin{array}{l}\text { Pega caneta e } \\
\text { papel para } \\
\text { escrever }\end{array}$ \\
\hline 00:55:05 & $\begin{array}{l}\text { 167. Fernando: ... [o aluno começa a consultar o Vogel em } \\
\text { silêncio]... }\end{array}$ & \\
\hline $00: 55: 17$ & $\begin{array}{l}\text { 168. Fernando: Cloreto, ácido nítrico... } \\
\text { 169. P: Porque o ácido nítrico? } \\
\text { 170. Fernando: ... [silêncio]... o cloreto reage. } \\
\text { 171. P: Sim, o cloreto reage. Então monta aqui uma tabela, } \\
\text { uma lista de possibilidades que podem ser sua amostra. }\end{array}$ & $\begin{array}{l}\text { O aluno } \\
\text { começa a } \\
\text { escrever }\end{array}$ \\
\hline 00:56:11 & 172. P: Olha, usando esta tabela aqui. Localiza então aqui & \\
\hline
\end{tabular}




\begin{tabular}{l} 
nesta tabela onde você tem prata. \\
173. Fernando: Aqui: acetatos, tiocianatos, cloretos e brometos \\
e sulfatos... e iodetos. \\
174. P: Então pronto. Você fez uma lista de quais são os \\
ânions que podem reagir com a prata. Então desta lista, pela \\
característica do precipitado, você verifica quem é quem. Que \\
característica te leva a comparar um com outro? \\
175. Fernando: A característica da amostra. \\
176. P: Então, se você mistura a prata com a sua amostra ela \\
forma um precipitado. Os precipitados são todos iguais? \\
177. Fernando: Hummm... \\
178. P: De maneira geral, uma coisa precipita. Os precipitados \\
são sempre iguais? \\
179. Fernando: Sim, são. \\
180. P: Tem sempre a mesma cor? \\
181. Fernando: São quase sempre brancos. \\
182. P: Podem ser brancos ou podem ser de outra cor? \\
183. Fernando: Não, mas de prata são sempre brancos. \\
184. P: Então testa aqui e verifica se todo o precipitado é \\
branco? \\
185. Fernando: Então vou pegar estes aqui ... [referindo-se aos \\
ânions] ... e vou testar com a prata? \\
186. P: Não sei... verifica aqui no Vogel... quer ver... se você \\
reagir a prata com o cloreto: precipitado branco. Se você reagir Retoma a \\
a prata com sulfeto: dá um precipitado preto. Então todo \\
precipitado é branco? \\
187. Fernando: Não! \\
188. P: Então como é que você vai diferenciar quem é quem? \\
189. Fernando: Pela cor do precipitado. \\
190. P: Ah! Então a cor do precipitado te ajuda a diferenciar o \\
ânion? Muito bom! \\
leitura \\
00:57:35el \\
\hline
\end{tabular}

Episódio 12: Continuação do episódio 9 com a execução de ensaio confirmatório para potássio

\begin{tabular}{lll}
\hline Tempo & Transcrição da fala & $\begin{array}{c}\text { Comentários } \\
\text { contextuais }\end{array}$ \\
\hline 00:59:51 & 191. P: Pelo ensaio de chama vocês eliminaram alguns cátions, \\
& e o que vocês acham que é? \\
& 192. Adriana: Ou potássio ou cálcio. Pelo ensaio de chama \\
& achamos que é isto. \\
& 193. P: Agora vocês precisam fazer um ensaio via úmida para \\
& eliminar um. Vocês estão fazendo esta escolha baseada em \\
& quê? \\
& 194. Diogenes: No potássio... pra começar. Ele ... [Vogel] ... \\
& fala assim: perclorato de potássio. Se adicionarmos perclorato \\
& na nossa amostra ela tem que ficar insolúvel. \\
& 195. P: Ta. \\
& 196. Diogenes: Então o potássio mais o perclorato tem que \\
& precipitar.
\end{tabular}


01:00:44 197. P: Então se a gente pegar ácido perclórico, estamos adicionando o perclorato. Então prepara a amostra mãe que eu vou pegar o ácido perclórico.

Adriana prepara o tubo de ensaio colocando a amostra Enquanto Adriana

$01: 01: 25$ enquanto o professor busca o reagente. prepara a amostra, Diogenes lê o

198. Diogenes: Então temos que observar que o ácido perclórico em contato com o potássio tem que formar o quê? Um precipitado branco, cristalino e ... esse precipitado é procedimento do Vogel

01:01:52 ligeiramente solúvel em água.

Diogenes pega a pipeta para iniciar o ensaio. Vai então

01:02:40 adicionando o ácido perclórico sobre a amostra. Todos observam em silêncio. Agita o tubo de ensaio.

199. Diogenes: Não houve reação nenhuma. Então isto aqui não pode ser potássio.

01:03:20 200. P: Então você conclui que não é potássio? 201. Diogenes: Não é, porque não houve nenhum precipitado. Como diz o livro aqui, o potássio em contato com o ácido manusear o perclórico forma um precipitado branco. Então está descartado Vogel o potássio. 202. Adriana: Então vamos para o próximo. Que é o cálcio... Vamos ver agora uma reação para o cálcio...

Episódio 13: Execução de ensaio confirmatório para potássio e argumentação a respeito do comprimento de onda espectral

\begin{tabular}{lll}
\hline Tempo & Transcrição da fala & $\begin{array}{c}\text { Comentários } \\
\text { contextuais }\end{array}$ \\
\hline & O aluno Fabio adiciona ácido perclórico sobre a amostra e \\
& observam se há reação. \\
& \\
& 203. Thiago: Então não reage... o ácido perclórico... então não \\
& é potássio. Olha ai: não deu nada. \\
& 204. P: Se fosse potássio? \\
& 205. Thiago: Formaria um precipitado branco. \\
& 206. P: Então este ensaio que vocês realizaram foi por causa da \\
& suspeita do ensaio de chama? \\
& 207. Thiago: Sim. \\
& 208. P: E qual é a segunda opção? \\
209. Fabio: Lítio. Agora a gente vai procurar um reagente para
\end{tabular}




\section{o lítio.}

210. P: Então vamos observar... cadê aquela folha lá? ... [aponta para a folha que contém as linhas espectrais] ... 211. Thiago: É que é assim também: eu não sou daltônico ...[risos]... eu vi vermelho e ele também.

212. P: Olha, vamos eliminar aqui o que vocês estão vendo. Vocês estão entre potássio e lítio.

213. Thiago: Isso.

01:08:12 214. P: Por conta da presença do vermelho.

Fala 215. Fabio: E do violeta.

216. P: Então vamos relembrar aquela questão do espectro. O espectro vai de 700 a 400, na região do visível. Então o que está acima de 700 ?

217. Thiago: Nós não vemos!

218. P: E abaixo? ...[referindo-se ao 400]...

219. Fabio: Também não.

220. P: Agora, nesta tabela de relação, o que são estes números?

221. Thiago: A intensidade, não é?

222. Fabio: O espectro. O comprimento de onda.

223. P: Agora, vocês ficaram em dúvida entre quem?

224. Fabio: Potássio e lítio.

225. P: Então, analisa o número. O número dos dois.

226. Fabio: O potássio, no caso, não aparece vermelho, porque ele está acima de 700, ele vai aparecer violeta. O lítio só que aparece com uma cor vermelha que a gente consegue enxergar. 227. P: E a chama de vocês tinha uma cor vermelha intensa?

228. Fabio: Sim, um vermelho intenso.

229. P: Então, se fosse potássio? ...

01:09:10 230. Thiago: Nós não iríamos ver.

231. P: Ah... então juntem agora esta informação: o

comprimento de onda com o resultado da análise por via úmida. Então realmente...

232. Fabio: Potássio não é.

233. P: Então como tinha uma cor vermelha intensa vocês acham que é o lítio? Que teste por via úmida podemos pensar para o lítio?

Os alunos começam a procurar no Vogel.

234. P: Vamos começar pela tabela de solubilidade? Onde tem lítio ai?

apontando para a folha em que estão as linhas espectrais

235. Fabio: Lítio tem aqui, onde aparece ele como insolúvel com carbonato.

236. P: Carbonato de lítio é insolúvel. Sua amostra é solúvel?

237. Fabio: Sim, é solúvel. Então carbonato de lítio não é.

238. P: Não é! Então não é carbonato de lítio.

239. Thiago: E ai, onde tem mais lítio? Não tem mais lítio. 240. P: Então agora vamos olhar no Vogel.

O professor pede a tabela e começa a analisá-la 
Episódio 14: Argumentação a sobre a reação para identificação do cálcio

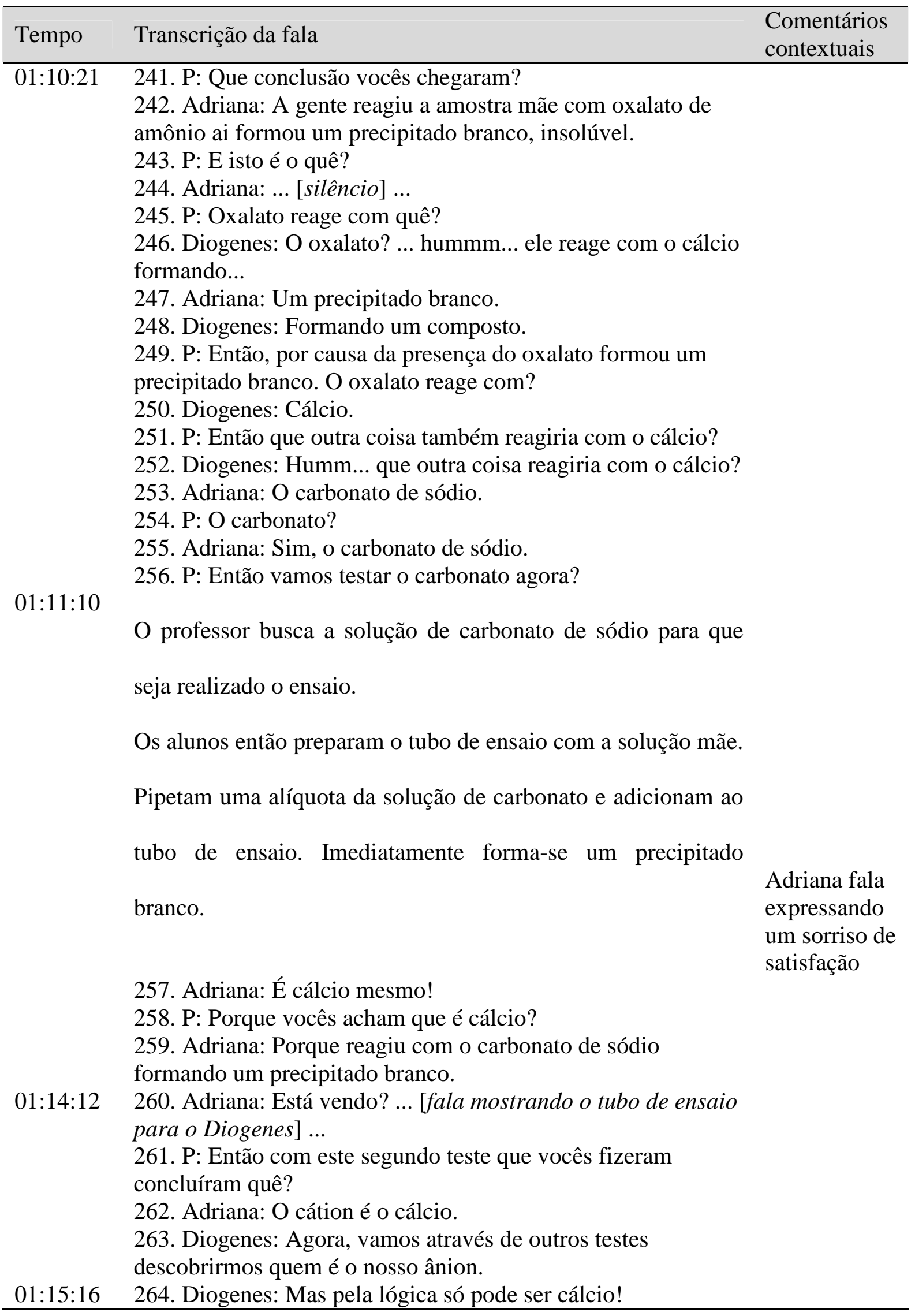


265. Diogenes: Pode ser cloreto, sulfato... pode ser cloreto de cálcio, sulfato de cálcio... o que mais?

266. Adriana: Vamos anotar o que nós fizemos.

267. Adriana: No ensaio de chama... via seca... ai você

coloca... Cálcio, apresentou... é... no ensaio de chama

obtemos... uma chama de cor alaranjada...

268. Adriana: Verde amarelada e violeta. Mas era isso mesmo!

Era o cálcio.

Continua escrevendo.

Episódio 15: Continuação da argumentação a respeito das marchas analíticas para determinação de lítio

\begin{tabular}{|c|c|c|}
\hline Tempo & Transcrição da fala & $\begin{array}{l}\text { Comentários } \\
\text { contextuais }\end{array}$ \\
\hline $01: 17: 10$ & $\begin{array}{l}\text { 269. Thiago: Nós pegamos o fosfato de sódio mais o hidróxido } \\
\text { de potássio, fizemos uma solução, pegamos a amostra mãe e } \\
\text { adicionamos aqui, onde ocorreu este precipitado. Ai ficou } \\
\text { turvo. } \\
\text { 270. P: Bem, só o fato de estar turvo é porque já houve uma } \\
\text { reação... Deixa eu ver uma coisa aqui... } \\
\text {... [pega a tabela de solubilidade]... }\end{array}$ & \\
\hline $01: 18: 22$ & $\begin{array}{l}\text { 271. P: Vamos organizar aqui... olha... Então, a amostra, ai } \\
\text { você fez o ensaio de chama e ficaram com quais } \\
\text { possibilidades? } \\
\text { 272. Thiago e Fabio: Potássio e lítio. } \\
\text { 273. Thiago: Ai, depois, em cima da folha do } \\
\text { espectrofotômetro vimos que potássio não é por causa do } \\
\text { comprimento da onda. } \\
\text { 274. P: Então vocês fizeram uma análise do comprimento de } \\
\text { onda? Do lambda? } \\
\text { 275. Thiago: Certo. Ai, em cima desta análise nós vimos que } \\
\text { não podia ser potássio porque é acima de } 700 \text {, e a gente não } \\
\text { consegue enxergar isto. } \\
\text { 276. P: Ok. } \\
\text { 277. Thiago: Ai a gente foi para o lítio. Ai fizemos a análise } \\
\text { de... de... de... } \\
\text { 278. P: Via úmida. } \\
\text { 279. Thiago: Isso, via úmida. Com solução de fosfato de sódio } \\
\text { e hidróxido de potássio com a amostra mãe, que gerou uma } \\
\text { turbidez da amostra. }\end{array}$ & $\begin{array}{l}\text { Pega uma } \\
\text { folha e } \\
\text { começa a } \\
\text { escrever }\end{array}$ \\
\hline $01: 19: 56$ & $\begin{array}{l}\text { 280. P: Vocês chegaram a colocar o hidróxido de sódio? } \\
\text { Deixaram o meio alcalino? Mais o fosfato? } \\
\text { 281. Thiago: Sim. } \\
\text { 282. P: Então ta. No ensaio via úmida vocês testaram fosfato. } \\
\text { Mas será que o fosfato reage só com o lítio? Ou ele pode ter } \\
\text { reagido com outro cátion? }\end{array}$ & \\
\hline
\end{tabular}


283. Fabio: Ele pode reagir com outro cátion, mas o ensaio de chama já provou pra gente que não tem outro cátion... bom, pode ser que tenha mais de dois cátions, pode ser que ele tenha reagido com outro cátion que não seja o lítio.

284. P: Vamos pensar o seguinte: vocês estão pensando que é lítio, ok? Pensa num outro teste para o lítio.

01:20:49 285. Fabio: Mas a gente já tem duas evidências que é o ensaio de chama mais essa reação... da outra... reação...

286. P: Onde tem lítio aqui? ... [mostra a tabela de solubilidade $]$...

287. Fabio: Onde tem lítio?

... [silêncio $] \ldots$

Thiago

continua

01:21:27 288. P: Onde tem lítio aqui?

lendo o

289. Thiago: Aqui, carbonato de lítio.

290. P: Então se for lítio e você colocar um carbonato?

Vogel

291. Thiago: Mas não é, porque no caso o carbonato de lítio é insolúvel.

292. P: Então, mas é alguma coisa de lítio. Se você colocar um carbonato, o que acontece com o lítio?

... [silêncio $] \ldots$

01:22:05 293. Fabio: Colocar o carbonato... com o lítio? ... [silêncio] ... Vai ficar insolúvel...

Os alunos começam então a preparar um tubo de ensaio para

reagir a amostra mãe com solução de carbonato de sódio.

01:24:02

294. Fabio: É lítio, com certeza!

295. Thiago: Olha ai Assesio, é lítio.

$01: 24: 29$

296. P: Então monta uma lista de tudo o que vocês já

Fabio

começa a

escrever na

testaram.

folha de

anotação

297. Fabio: A gente usou ... [fala soletrando a fórmula] ...

$\mathrm{Na}_{2} \mathrm{CO}_{3}$

298. Thiago: Carbonato de sódio.

299. Fabio: Que ficou insolúvel. A amostra reagiu com

carbonato de sódio ficando insolúvel.

300. Thiago: A gente reagiu fosfato de sódio...

301. Fabio: Mais o hidróxido de potássio... hidróxido de

potássio serve para acelerar a reação, não é? 
302. P: É, o fosfato em meio alcalino...

303. Fabio: Reagiu então formando turbidez. Precipitado não...

01:26:53 formando duas fases...

O Thiago pega o respectivo tubo de ensaio.

304. Thiago: Está precipitando, não está?

305. P: Sim, está.

306. Thiago: Mas e agora?

307. Fabio: Agora a gente já tem três evidência que é lítio:

ensaio de chama, a reação com fosfato e a reação com

carbonato. Três evidências. Carbonato de lítio já não é, porque

ele é insolúvel.

308. P: Então é alguma coisa de lítio?

309. Fabio: E não é carbonato porque não dá hidrólise básica.

310. P: Porque o lítio veio de uma base forte.

311. Fabio: O ânion, no caso, a gente já vai começar a pensar num ácido forte: clorídrico, sulfúrico, fluorídrico...

01:28:12 no...?

312. P: Então se você pensar no clorídrico tem que pensar

313. Fabio: Cloreto... fluoreto, sulfúrico...

314. P: Tem que pensar no cloreto, fluoreto, sulfato... pode ser nitrato... todos vieram de ácidos fortes.

315. Fabio: Tem quem montar uma tabelinha então.

Fabio começa a montar uma tabela e vai falando em voz alta

os ânions que serão pesquisados.

Após isto começam a pesquisar no Vogel.

Episódio 16: Argumentação a respeito da marcha analítica para identificação de cloreto

\begin{tabular}{lll}
\hline Tempo & Transcrição da fala & $\begin{array}{l}\text { Comentários } \\
\text { contextuais }\end{array}$ \\
\hline 01:29:36 & $\begin{array}{l}\text { 316. P: Cloreto de prata é insolúvel. Cloreto de chumbo } \\
\text { também. Nós colocamos chumbo ai e não precipitou. Eu usei } \\
\text { nitrato de chumbo, então eu peguei o chumbo o misturei com a } \\
\text { amostra que eu acho que é cloreto e não precipitou. }\end{array}$ & \\
& 317. Adriana: Exato! \\
& 318. P: Agora, vocês estão pensando no fluoreto. Porque você \\
está pensando no fluoreto? & \\
& $\begin{array}{l}\text { 319. Diogenes: Porque é assim: quando nós colocamos o } \\
\text { sulfato de... }\end{array}$ \\
& ... [silêncio] ... & \\
& 320. P: Então o que o método fala ai? & Fazem juntos \\
\hline
\end{tabular}




\begin{tabular}{ll}
\hline precipitado. & a leitura do \\
322. P: Olha: solução de nitrato de prata, nenhum precipitado... & Vogel \\
323. Diogenes: Pois o fluoreto de prata é solúvel em água. & \\
324. P: Então a sua amostra é o quê? Cloreto ou um fluoreto? & \\
& \\
.. [ silêncio] ... & \\
325. P: E agora? & \\
326. Diogenes: Soluções com cloreto de cálcio causam um \\
precipitado branco, viscoso de fluoreto de cálcio. \\
327. P: Mas leia de novo o item três. \\
328. Diogenes: Solução de nitrato de prata, nenhum \\
precipitado, pois o fluoreto de prata é solúvel em água. \\
329. Adriana: Mas então, olha a prata. Não é o fluoreto que ele \\
está falando. Na presença de prata não ia formar nenhum \\
precipitado. Mas aqui formou, não é o fluoreto. \\
330. P: Agora, pela tabela aqui, pra confirmar cloreto, nós \\
podemos testar o ... [fala apontando para a tabela] ... \\
331. Adriana e Diogenes: Chumbo! \\
$\begin{array}{l}\text { 332. P: E quando nós usamos o chumbo deu precipitado? } \\
\text { 333. Diogenes: Não, não deu nenhum precipitado. }\end{array}$ \\
334. P: Vamos tentar de novo. \\
$\begin{array}{l}\text { Os alunos preparam nova amostra colocando no tubo de } \\
\text { ensaio enquanto o professor vai buscar o reagente. }\end{array}$ \\
\hline
\end{tabular}

\section{2}

Episódio 17: Argumentação a respeito da marcha para identificação do sulfato

\begin{tabular}{|c|c|c|}
\hline Tempo & Transcrição da fala & $\begin{array}{l}\text { Comentários } \\
\text { contextuais }\end{array}$ \\
\hline \multirow{2}{*}{$00: 01: 15$} & $\begin{array}{l}\text { Os alunos estão discutindo a marcha, então o professor } \\
\text { interrompe e inicia uma argumentação dialógica. }\end{array}$ & \\
\hline & $\begin{array}{l}\text { 335. P: Vocês acharam que era sulfato? } \\
\text { 336. Renato: Sulfato de lítio. } \\
\text { 337. P: E vocês fizeram qual sequiência para confirmarem isso? } \\
\text { 338. Claudinei: O sulfato precipita. } \\
\text { 339. P: Com o quê? } \\
\text { 340. Renato: Com o nitrato de chumbo, causando sulfato de } \\
\text { chumbo, um precipitado. Depois com nitrato de prata, pra } \\
\text { sempre forçar o lítio a ser um nitrato, sendo solúvel e forçar } \\
\text { um precipitado, no caso as exceções do sulfato, que foram a } \\
\text { prata, se eu não me engano, e chumbo, certo? Cadê... Prata e } \\
\text { chumbo. Por isso tentamos também com estrôncio para } \\
\text { provocar um precipitado de estrôncio, o sulfato de estrôncio. } \\
\text { 341. P: E precipitou? }\end{array}$ & $\begin{array}{l}\text { Argumenta } \\
\text { lendo a } \\
\text { tabela de } \\
\text { solubilidade }\end{array}$ \\
\hline
\end{tabular}




\begin{tabular}{ll}
\hline 00:02:11 & 342. Renato: Não precipitou. Eis a questão. \\
& 343. P: Então a conclusão que vocês chegaram é que? \\
& 344. Renato: Seria realmente o sulfato? Por quê? Com duas \\
reações fez a seqüência: reagiu e precipitou. E conforme Vogel \\
o precipitado está de acordo. Coloração, aspecto. \\
345. P: E o estrôncio? \\
346. Renato: Não precipitou. \\
347. P: Então pode ser sulfato? \\
348. Renato: No caso, com estrôncio não. \\
349. Claudinei: Mas a prata e o chumbo são de nitrato. \\
350. Renato: Mas é isto que eu estava te explicando, de uma \\
dupla troca, ele não é mais um cloreto, quem é o cloreto agora \\
é o lítio. O cloreto de lítio é solúvel. E o estrôncio, que no caso \\
era um cloreto antes, agora se tornou sulfato. \\
351. Claudinei: Mas ele tinha que precipitar. \\
352. Renato: Mas ele não precipitou. O que acontece? É um \\
sulfato? Mas que cátion é este aqui? O que comprova isto \\
aqui? Seria contaminação? \\
353. Wendel: Sim! \\
354. Claudinei: Ou a gente faz mais uma desta pra confirmar \\
ou parte para outras análises.
\end{tabular}

Episódio 18: Argumentação a respeito das marchas analíticas realizadas para o cátion e ânion

\begin{tabular}{lll}
\hline Tempo & Transcrição da fala & $\begin{array}{c}\text { Comentários } \\
\text { contextuais }\end{array}$ \\
\hline 00:03:47 & 355. P: Vocês estão pesquisando agora os ânions? \\
& 356. Arlindo: Exato! \\
& 357. P: Como é que vocês começariam a fazer esta pesquisa? \\
& Como vocês começariam a pensar no ânion? \\
& 358. Arlindo: Colocaríamos algum cátion que... \\
& 359. Luciana: Que reaja com o cátion que é o cálcio. \\
& 360. Arlindo: Não, mas veja... posso estar até errado... nós já \\
& achamos o cálcio, então nós temos que colocar outro cátion \\
& que reaja com o ânion da solução. Vamos colocar então a \\
& prata. A prata vai reagir com o ânion da solução pra gente \\
& descobrir o que é. \\
& 361. Luciana: Ham, ham... [confirma com a cabeça]... \\
& 362. P: O que a prata é neste caso então? \\
& 363. Luciana: O cátion! \\
& 364. Arlindo: É... o cátion reagente do ânion da fórmula. \\
& 365. P: Então ele é o reagente de ... ? ... grupo ... Então vocês \\
& terão que fazer uma separação: quem reage com a prata? \\
& 366. Arlindo: Ah ta, entendi! Quem reage com a prata? ... O \\
& regente de grupo... quem reage coma prata... \\
& \\
& Pegam então o Vogel e iniciam uma procura dos ânions que \\
&
\end{tabular}


00:04:59 367. P: Será que inicialmente com a tabela não é mais fácil?

368. Luciana: Acho que sim.

Abandonam o Vogel e concentram-se na leitura e interpretação

00:05:12 da tabela.

369. Luciana: Estes não são solúveis... este não... este não... [fala marcando com o lápis os ânions descritos na tabela]...

370. Arlindo: A partir do momento que eu colocar a prata tem que formar um precipitado insolúvel em água.

371. Luciana: Insolúvel.

372. Luciana: O iodeto...

373. Arlindo: O iodeto de prata... o cloreto de prata... Os nitratos, todos são solúveis.

00:05:45

Pegam os frascos e começam a procurar algum reagente.

375. P: Como vocês acharam o cátion? Descrevam como foi a análise.

376. Arlindo: Fizemos primeiro o ensaio de chama...

377. Luciana: O ensaio de chama... ai a chama tinha três colorações... não é? Primeiramente era laranja, depois verde e no finalzinho um tom de violeta claro.

378. P: Humm... e ai?

379. Luciana: Ai deduzimos que era o cálcio pelo ensaio de chama pois tinha cor de laranja, ai nós usamos a tabela e na tabela não tinha.

380. P: Desde o princípio vocês acharam que era cálcio?

381. Luciana: Não!

00:06:47 382. P: Qual era a primeira evidência? O que vocês fizeram?

383. Luciana: A gente acho primeiro que era o lítio. A gente não enxergava o verde. $\mathrm{O}$ verde a gente enxergou depois.

384. P: Ai vocês começaram um ensaio via úmida?

385. Luciana: Ai, pesquisamos no livro e fizemos os testes.

Diluímos em água e vimos que era solúvel, pela tabela... totalmente solúvel.

386. P: O que é totalmente solúvel?

387. Luciana: A amostra. Até então a gente achava que era... a amostra era solúvel em água.

388. P: Ok!

389. Luciana: Ai depois utilizamos oxalato de amônio, ai formou um precipitado branco.

390. P: E isto evidencia o quê?

391. Luciana: ... [silêncio]...

392. P: Quando você coloca uma solução de oxalato de referindo-se

a tabela de

solubilidade

Fala sorrindo

Luciana faz

uma

expressão de

dúvida 
amônio na sua amostra o que ocorre?

393. Luciana: Ele ficou um líquido branco.

Ângela pega o tubo de ensaio contendo a reação descrita.

394. Ângela: Ficou leitoso.

00:07:50 395. P: E isto evidencia a formação de um... ?

... [silêncio $] \ldots$

396. P: A amostra é solúvel e quando você adicionou o reagente de grupo, que era o oxalato, o que houve como evidência?

397. Ângela: Ele...

398. Luciana: Houve uma reação...

399. P: E o que evidencia que houve esta reação?

Arlindo fala 400. Arlindo: Primeiro formou um precipitado.

401. P: Então formou um precipitado?

402. Arlindo: É! E ele é solúvel em água... nós adicionamos mais água e ele dissolveu legal.

403. Ângela e Lucina: Não! Ele é solúvel em ácido sulfúrico.

00:08:35 404. Lucina: O primeiro é este aqui... [fala apontando para $o$

tubo de ensaio]... Ai nós adicionamos mais água e não

dissolveu.

405. Ângela: Não dissolveu!

406. P: Um precipitado depois de formando pode dissolver?

407. Luciana, Ângela e Arlindo: Não!

408. P: Ah, entendi.

409. Lucina: Ah, depende, porque com ácido sulfúrico... ele formou um precipitado branco, ai nós adicionamos mais água, então nós adicionamos mais água e por causa dessa quantidade de água ele acabou dissolvendo.

410. P: E o fato de você adicionar mais água o que você fez?

411. Luciana: Diluímos cada vez mais a solução.

00:09:15 412. P: Então diluir uma solução, com uma coisa que está precipitada, pode ficar solúvel?

413. Ângela: Pode! Ficou! A amostra ficou.

414. Luciana: Como o cálcio é solúvel em água, quando a gente adicionou mais água no ácido sulfúrico ai ele diluiu. Então não foi o ácido sulfúrico que diluiu o cálcio, foi a água que a gente adicionou no ácido sulfúrico.

415. P: Então na verdade quando você adiciona ácido sulfúrico você reagiu que ânion com que cátion?

00:09:43 … [silêncio]...

416. P: Porque aqui você adicionou oxalato e ai formou um precipitado branco que...

417. Luciana: É a amostra mais... alguma coisa...

Luciana 
00:10:38

418. P: E essa alguma coisa o que é?

419. Lucina: É o oxalato.

420. P: Então formou o oxalato de ... ?

421. Luciana e Ângela: De cálcio.

422. P: Ok!

423. P: Ai agora você colocou ácido sulfúrico e ...?

424. Luciana: Com água mais a amostra.

425. P: E o que formou?

426. Ângela: Um precipitado branco.

427. Luciana: Então, espera ai...

... [escreve a fórmula com a ajuda da Ângela que está

428. Luciana: $\mathrm{Ca}_{2} \mathrm{SO}_{4}$.

429. P: Que é solúvel ou insolúvel?

430. Ângela: Ele é... hum....

... [começa a procurar nos frascos a solução]...

431. Luciana: Não, ele é insolúvel. Com água. Ai a água dissolveu esse... [aponta para a fórmula escrita na folha]... Não é isso? Porque quando a gente adicionou o ácido sulfúrico

00:11:23 com a amostra formou o sulfato de cálcio, ai, adicionando água dissolveu tudo... Então, quando adicionou a amostra com ácido sulfúrico formou um precipitado e ai adicionando água diluiu.

432. P: Agora você tem quantas evidências pra te mostrar que é cálcio?

433. Ângela: Três.

434. Luciana: Três por via úmida e o ensaio de chama.

435. P: Quais são os de via úmida?

436. Ângela: O oxalato de amônio...

437. Luciana: A água... e o ácido sulfúrico.

438. Ângela: Diluído.

439. P: Então vamos separar: oxalato, sulfato e ...

440. Luciana: Que ele é solúvel em água. Que foi o primeiro teste que a gente fez. A gente foi na tabela e viu que ele era solúvel em água.

441. P: Haveria mais um teste para provar que é cálcio?

442. Luciana: Haveria!

443. P: Qual?

00:12:21 444. Ângela: Abre ai... [aponta para o Vogel]...

Começam a folhear o Vogel. 
445. P: Qual o reagente de grupo mais comum para cálcio?

446. Luciana: O carbonato! Não é?

447. P: Vocês fizeram teste com o carbonato?

448. Luciana: ...[responde negativamente com a cabeça]...

449. P: Então faça uma previsão: se efetivamente for cálcio e

se você adicionar carbonato o que vai acontecer?

Os alunos ficam em silêncio e não responde a questão.

Episódio 19: Argumentação a respeito das reações para determinação do ânion através das evidências que levam a exclusão ou confirmação

\begin{tabular}{|c|c|c|}
\hline Tempo & Transcrição da fala & $\begin{array}{l}\text { Comentários } \\
\text { contextuais }\end{array}$ \\
\hline $00: 12: 47$ & $\begin{array}{l}\text { 450. P: Como vocês estão fazendo a pesquisa do ânion agora? } \\
\text { 451. Renato: Então, agora seria... observando a tabela, } \\
\text { comparando as exceções, no caso, os reagentes de grupo... } \\
\text { 452. P: Me explica esta seqüência de reações... que conclusões } \\
\text { vocês chegaram? }\end{array}$ & $\begin{array}{l}\text { O P aponta } \\
\text { para as }\end{array}$ \\
\hline $00: 13: 18$ & $\begin{array}{l}\text { 453. Renato: Primeiro nós pensávamos que era um carbonato, } \\
\text { o ânion, reagimos ele com o alumínio para forçar uma } \\
\text { precipitação de carbonato de alumínio, porque na tabela ele é } \\
\text { insolúvel. O que aconteceu? Ele nos mostrou que não era, } \\
\text { porque ele não precipitou, ficou solúvel. Isto nos mostrou que } \\
\text { não era o carbonato. Nós descartamos e fomos até o sulfato. } \\
\text { 454. P: Se fosse carbonato, não tem um teste específico para } \\
\text { carbonato? } \\
\text { 455. Renato: Tem, todo o carbonato na presença de um ácido } \\
\text { causa efervescência. } \\
\text { 456. P: E isto aconteceu? } \\
\text { 457. Renato: Não. Não reagiu, ficou normal. Então isso } \\
\text { reforçou que não era o carbonato. Descartamos a hipótese e } \\
\text { fomos para outro ânion, o sulfato. Reagimos o sulfato com o } \\
\text { chumbo que nos confirmou a precipitação do sulfato de } \\
\text { chumbo e reagimos também o sulfato com a prata que nos } \\
\text { forçou ao sulfato de prata, um precipitado. Quando chegamos } \\
\text { ao estrôncio, o sulfato de estrôncio tinha que precipitar, } \\
\text { quando nós reagimos não precipitou, ficou solúvel. Isto nos } \\
\text { mostrou que não era um sulfato. Agora chegamos a conclusão } \\
\text { que nós temos que analisar primeiro os compostos e os } \\
\text { reagente de grupo. } \\
458 \text {. P: Que são quais? }\end{array}$ & $\begin{array}{l}\text { anotações do } \\
\text { grupo }\end{array}$ \\
\hline $00: 14: 58$ & $\begin{array}{l}\text { 459. Renato: Prata e chumbo... Agora vamos reiniciar... } \\
\text { 460. P: Então vocês ficaram com a prata e o chumbo por quê? } \\
\text { 461. Renato: Porque eles são dois reagente que nos mostra que } \\
\text { eles são, em alguns... em alguns compostos eles forçam a } \\
\text { precipitação. } \\
\text { 462. P: Ok! } \\
\text { 463. Claudinei: Que seria agora o iodeto... já eliminamos os }\end{array}$ & \\
\hline
\end{tabular}




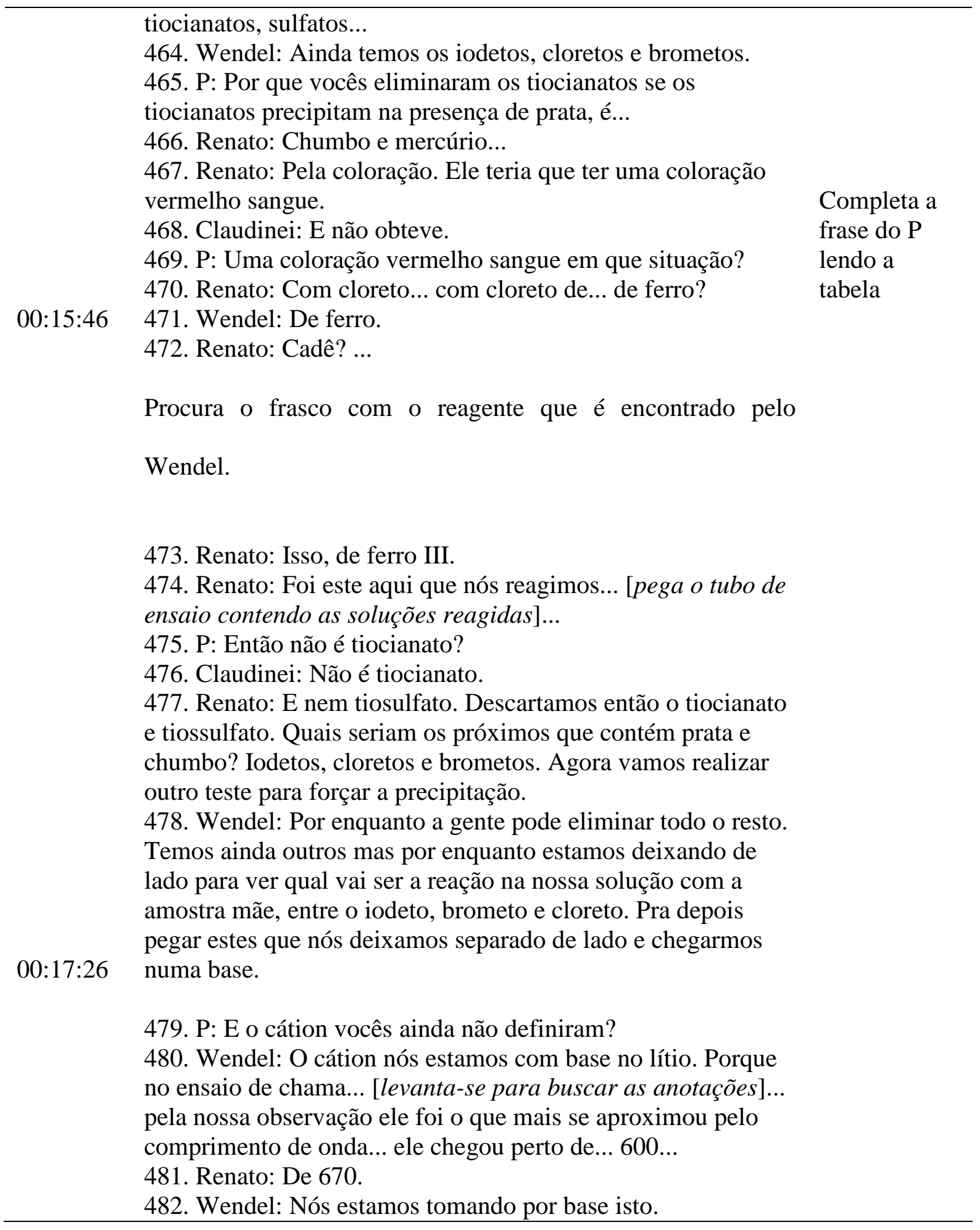

Episódio 20: Argumentação sobre a marcha para determinação do ânion

\begin{tabular}{lll}
\hline Tempo & Transcrição da fala & $\begin{array}{l}\text { Comentários } \\
\text { contextuais }\end{array}$ \\
\hline 00:18:07 & $\begin{array}{l}\text { 483. Como vocês fizeram os testes para o ânion? } \\
\end{array}$ & \\
& $\begin{array}{l}\text { 484. Arlindo: Primeiro nós colocamos... diluímos... pegamos a } \\
\text { amostra mãe e adicionamos nitrato de prata. Formou um } \\
\text { precipitado branco. }\end{array}$ & \\
\hline
\end{tabular}


485. P: Isto significa que a prata então...

486. Arlindo: Reagiu com o ânion da solução, que a gente não sabe qual é.

487. P: E a prata reage com quais ânions?

488. Arlindo: Ai nós começamos pelo carbonato, sulfeto, mas já eliminamos. Só que ai nós fizemos outro teste depois e não reagiu.

489. P: Ham... ham...

490. Arlindo: Ai nós colocamos ácido clorídrico pra ver se reagiu e não reagiu, e depois colocamos também bário pra ver se reagiu e não reagiu. $\mathrm{O}$ bário era para o sulfeto e o ácido clorídrico era para reagir com o carbonato, só que não reagiu. 491. P: Então vocês coloram uma solução de carbonato na

00:18:54 amostra?

492. Arlindo: Não professor! Nós fizemos assim: nós pegamos a amostra mãe e colocamos o reagente nitrato de prata, reagiu. Ai nós começamos a procurar qual grupo que reage com a prata, quais ânions reagem com a prata. $\mathrm{O}$ carbonato é um, o sulfato é outro... o sulfito. Então nós vimos quais outras reações que podem ocorrer.

493. P: Com a prata?

494. Arlindo: Para confirmar que seja carbonato, por exemplo, a prata reage também com carbonato, mas não somente com carbonato, com outros também pode ocorrer também. Então nós fizemos isso, com o carbonato. 495. P: Então, mas como vocês fizeram? Eu não estou

00:19:42 entendendo o que vocês fizeram .... mostra aqui... o que vocês fizeram?

Arlindo pega o tubo de ensaio que o professor apontou.

496. P: O que é isso?

497. Arlindo: A amostra mãe mais nitrato de prata.

498. P: Então a prata reagiu com o ânion da amostra. Ok! O que mais a gente tem?

499. Arlindo: Ai então eu coloquei cloreto de bário... [pega outro tudo de ensaio] ...

500. P: Então, o que tem ai?

501. Arlindo: A amostra mãe mais cloreto de bário.

502. P: A amostra mãe mais cloreto de bário...

503. Arlindo: Que neste caso iria reagir só o bário e não reagiu.

504. P: Me explica então esta reação deste tubo, deste ai.

Arlindo pega novamente o primeiro tubo.

505. Arlindo: Primeiramente, fizemos a solução de ... colocamos ... [silêncio] ... colocamos ... a amostra mãe mais a 
prata ai reagiu. Ai então nós vamos ver qual pode ser?

Carbonato. O carbonato pode ser porque ele reage com a prata e forma um precipitado branco. Então vamos fazer um segundo teste. Pelo Vogel aqui, tem que ser ácido clorídrico diluído, peguei ácido clorídrico diluído e joguei na amostra mãe, não reagiu. Então eliminamos este do grupo. No segundo a gente foi para o ... [começa a folhear o Vogel $].$.

O professor lê nas anotações que o grupo adicionou também

00:21:22 ácido sulfúrico sobre a amostra.

506. P: Mas você não está pesquisando o ânion?

507. Arlindo: Sim!

508. Então se você jogar ácido sulfúrico você está querendo qual ânion do ácido sulfúrico?

509. Não entendi professor.

510. Arlindo: Quem é o ânion do ácido sulfúrico? Quem é o cátion e quem é o ânion?

$00: 21: 49$

... $[$ silêncio $] \ldots$

511. P: Escreve a fórmula dele.

512. Arlindo: Está aqui: $\mathrm{H}_{2} \mathrm{SO}_{4} \ldots$... [fala soletrando]...

513. P: Então quem é o cátion?

514. Arlindo: O hidrogênio. Aqui, o cátion!

00:22:10 515. P: E quem é o ânion?

516. Arlindo: Deixa eu pegar a tabela aqui...

Procura na tabela de cátions e ânions

517. Arlindo: O sulfato!

518. P: Mas se você está pesquisando o ânion da sua amostra, ânion reage com ânion?

519. Arlindo: Não!

520. P: Então porque você adicionou... teria que ter precipitado ânion com ânion?

521. Arlindo: Não!

522. P: Então neste segundo tubo em que você colocou a amostra mais ácido sulfúrico...

523. Arlindo: Não deveria ter precipitado.

524. P: Então não tem precipitado porque não deveria ter precipitado.

525. Arlindo: Ah ta!

526. P: Entendeu?

527. Arlindo: Entendi. O ânion com o ânion. Deveria ter precipitado só...

528. P: O hidrogênio com o ânion. 
Episódio 21: Argumentação sobre a reação com a amostra e o reagente de grupo

\begin{tabular}{lll}
\hline Tempo & Transcrição da fala & $\begin{array}{c}\text { Comentários } \\
\text { contextuais }\end{array}$ \\
\hline 00:22:53 & 529. Arlindo: Mas e ai, vocês acharam que é o quê? \\
& 530. Luciana: Então, a gente fez o nitrato de prata com o \\
& carbonato... não... com o cloreto de cálcio. E ai formou um \\
& precipitado branco. \\
& 531. Ângela: Que é este aqui! ... [fala mostrando o tubo de \\
& ensaio] ... \\
& 532. P: Como vocês fizeram isto? Onde está a amostra de \\
& vocês ai? \\
& 533. Ângela: É não tem amostra! \\
& 534. Luciana: Por quê? Eu estou usando o cloreto. \\
& 535. P: E cadê a amostra? \\
& 536. Arlindo: Tem que reagir na amostra, entendeu? \\
& 537. Luciana: Então esquece, não é nada disso. \\
& 538. P: Você tem que pegar a amostra e reagir a amostra com o \\
& reagente de grupo. Caso a sua amostra seja um cloreto ocorre \\
& um precipitado, caso não seja, não ocorre. Neste caso, vocês \\
& pegaram um cloreto e reagiram com a prata. Então isto é só \\
para vocês saberem que cloreto com prata precipita. Agora, se \\
você pegar a prata, reagir com a sua amostra e houver um \\
precipitado, provavelmente a sua amostra é de ... ? \\
539. Luciana: Cálcio. \\
540. Ângela: Não, de cloreto. \\
541. Luciana: Ah, cloreto, entendi. \\
542. P: Então vocês fizeram um teste e onde está a sua \\
amostra? \\
543. Ângela e Luciana: Não está! \\
544. Luciana: Então tem que por a amostra. \\
\end{tabular}

Episódio 22: Argumentação a respeito da cor do precipitado obtido

\begin{tabular}{lll}
\hline Tempo & Transcrição da fala & $\begin{array}{l}\text { Comentários } \\
\text { contextuais }\end{array}$ \\
\hline 00:24:30 & 545. P: Repassa a lista então do que reage com a prata. & $\begin{array}{l}\text { Os alunos } \\
\text { estavam } \\
\text { escrevendo } \\
\text { 546. Arlindo: Acetatos, tiocianatos, cloretos e sulfatos. }\end{array}$ \\
& 547. P: Tem mais! & \\
& 548. Luciana: Tiossulfatos e brometos. & \\
& 549. P. Tem mais! & \\
& 550. Arlindo: Sulfatos, iodetos... & \\
& 551. Luciana: Isso, iodetos. & \\
& 552. P: Então repassa: acetatos... & \\
& 553. Luciana: Tiocianatos, tiossulfatos, cloretos, brometos, & \\
& iodetos e sulfatos. & \\
& 554. P: Ok! Agora, todos eles com a prata formam um \\
& precipitado. O que é que diferenciaria um precipitado do \\
& outro? & \\
555. Arlindo: A cor! &
\end{tabular}


556. P: A cor?

557. Arlindo: É, a gente viu em um ali que eu não me lembro qual era que forma um precipitado amarelo, só que a nossa amostra formou um precipitado branco.

558. Luciana: Com o nitrato.

559. Arlindo: Foi com o nitrato que formou um precipitado amarelo? Só que a nossa amostra formou um precipitado branco.

560. P: Como assim com o nitrato?

561. Arlindo: O nitrato é solúvel, não é?

562. Luciana: Não, não é com o nitrato.

Começam a folhear o Vogel.

$00: 25: 47$

563. P: Olha, vocês precisam fazer agora é fazer uma

separação de quem é quem pela cor do precipitado. Então olha: acetato de prata, qual é a cor?

564. Luciana: A gente não tem.

565. P: Vamos fazer o seguinte? Vocês agora relacionam todos os precipitados de prata com a cor e olha no Vogel. Vocês só vão conseguir isso pelo Vogel.

566. Ângela: Ta!

Episódio 23: Argumentação a respeito da pesquisa de ânion e a análise do cátion apenas pelo ensaio de chama

\begin{tabular}{|c|c|c|}
\hline Tempo & Transcrição da fala & $\begin{array}{l}\text { Comentários } \\
\text { contextuais }\end{array}$ \\
\hline $00: 26: 16$ & $\begin{array}{l}\text { 567. P: Eu queria que vocês argumentassem quais são, quais } \\
\text { foram as reações. Que conclusões vocês chegaram? } \\
568 \text {. Wendel: De todas as reações que a gente fez a gente } \\
\text { eliminou o tiocianato, o tiossulfato, esse fluoreto nem conta, o } \\
\text { sulfato e os carbonatos. } \\
\text { 569. Renato: Certo! } \\
\text { 570. Wendel: Ai sobraram três: os cloretos, os iodetos e os } \\
\text { brometos. } \\
\text { 571. Renato: O iodeto, ao reagir com a prata tinha que causar } \\
\text { um precipitado amarelo e floculento. Quando reagimos... } \\
\text { Renato pega o tubo de ensaio contendo a reação. }\end{array}$ & $\begin{array}{l}\text { Falam lendo } \\
\text { as anotações } \\
\text { registradas } \\
\text { durante a } \\
\text { realização da } \\
\text { marcha } \\
\text { analítica }\end{array}$ \\
\hline
\end{tabular}


00:27:37 576. Renato: Pra confirmar, se não era um brometo, o que nós fizemos: viemos aqui no Vogel e analisamos o que está escrito em brometos quando reagido com nitrato de prata, ele seria um precipitado amarelo pálido. Então eliminamos o brometo... 577. Claudinei: E os iodetos. E chegamos ao ânion.

578. Renato: Descobrimos que a amostra seria o cloreto de lítio.

579. P: E como vocês chegaram a conclusão que é o lítio?

00:28:05 580. Renato: Devido a coloração do ensaio de chama.

581. Wendel: Era uma coloração avermelhada, com um laranja bem fraco.

582. P: E vocês não fizeram nenhum teste via úmida para testar lítio?

583. Renato: Via úmida para lítio não.

584. P: Vocês poderiam chegar a uma conclusão decisiva que o cátion é o lítio só pelo ensaio de chama?

585. Renato: Creio que não.

586. P: Quais são os interferentes de um ensaio de chama?

587. Wendel: A contaminação?

00:28:43 588: P: Contaminação do quê? Da amostra? Do fio?

589. Renato: Do fio.

590. P: Do fio.

591. Wendel: Mas para não ter esta dúvida nós fizemos o teste várias vezes, limpamos o fio várias vezes para podermos tirar esta conclusão que seria este lítio.

592. P: A cor do espectro no ensaio de chama é facilmente perceptível a olho nu ou não?

593. Renato: Não!

594. P: $\mathrm{O}$ analista pode se enganar?

595. Wendel e Renato: Sim, pode.

596. Wendel: Sim, ocorreu, tanto que no ensaio de chama a gente estava analisando baseado no branco da folha e no branco do jaleco e o Claudinei estava falando que estava vendo um amarelo, então eu mostrei pra ele de novo que só tinha o vermelho e o laranja na base.

597. P: Então vocês teriam que fazer um ensaio via úmida pra

00:29:40 confirmar se é lítio?

598. Wendel: Sim, pra confirmar se é lítio.

599. P: E vocês não fizeram?

600. Wendel: Não fizemos.

601. P: Pretendem fazer?

602. Wendel: A gente vai fazer agora.

Começam então a procurar no Vogel um ensaio via úmida para o lítio. 
Episódio 24: Argumentação a respeito das marchas analíticas realizadas e as conclusões do grupo

\begin{tabular}{|c|c|c|}
\hline Tempo & Transcrição da fala & $\begin{array}{l}\text { Comentários } \\
\text { contextuais }\end{array}$ \\
\hline \multirow[t]{2}{*}{$00: 30: 22$} & $\begin{array}{l}\text { 603. P: Vamos fazer o seguinte: me explica esta lista que vocês } \\
\text { construíram. } \\
\text { 604. Luciana: Então... [silêncio] ... a gente pegou... } \\
\text { 605. Arlindo: Nós colocamos a prata que reagiu e formou um } \\
\text { precipitado branco. Depois nós vimos quais outros reagentes } \\
\text { podem reagir com a prata e formar um precipitado branco. } \\
\text { 606. P: Quem são estes reagentes? } \\
\text { 607. Arlindo: Foi o ... acetato, tiocianeto... } \\
\text { 608. Luciana: Tiocianato ... [corrige o colega] ... } \\
\text { 609. Luciana e Arlindo: Cloretos, sulfatos e tiossulfatos. } \\
\text { 610. P: Porque o iodeto reage com a prata e não está nesta } \\
\text { lista? }\end{array}$ & \multirow[t]{2}{*}{$\begin{array}{l}\text { Falam lendo } \\
\text { as anotações } \\
\text { do grupo }\end{array}$} \\
\hline & ... [silêncio $] \ldots$ & \\
\hline $00: 30: 58$ & $\begin{array}{l}\text { 611. Arlindo: Porque dá um precipitado amarelado e não } \\
\text { branco. } \\
\text { 612. P: Ah, entendi... ai vocês foram agora fazendo testes para } \\
\text { eliminar? ... Como é que vocês eliminaram o acetato? } \\
\text { 613. Luciana: Porque ele não formou um precipitado branco. } \\
\text { Formou uma coloração amarela. } \\
\text { 614. Arlindo: A gente colocou com outro reagente. } \\
\text { 615. P: Não... espera ai, não entendi. } \\
\text { 616. Arlindo: A gente fez um segundo teste. } \\
\text { 617. P: Que cor é o acetato com prata...? Fica...? } \\
\text { 618. Arlindo: Branco. } \\
\text { 619. P: E pra descobrir se realmente é acetato, vocês usaram } \\
\text { qual outro reagente? }\end{array}$ & \multirow[t]{3}{*}{$\begin{array}{l}\text { Os dois } \\
\text { falam ao } \\
\text { mesmo } \\
\text { tempo }\end{array}$} \\
\hline & ... [silêncio e risos $] \ldots$ & \\
\hline & $\begin{array}{l}\text { 620. P: Não foi o cloreto de ferro III? } \\
\text { 621. Luciana: Foi. } \\
\text { 622. Ângela: Foi e ficou amarelo. } \\
\text { 623. P: Então se fosse acetato deveria ter ficado que cor? } \\
\text { 624. Luciana: Vermelho. } \\
\text { 625. P: E ficou vermelho intenso? } \\
\text { 626. Arlindo, Luciana e Ângela: Não! } \\
\text { 627. P: Então é acetato? } \\
\text { 628. Arlindo, Luciana e Ângela: Não! }\end{array}$ & \\
\hline $00: 31: 38$ & $\begin{array}{l}\text { 629. P: Então vamos para o próximo. } \\
\text { 630. Arlindo: Tiocianeto. } \\
\text { 631. Luciana: Não, tiocianato ... [corrige novamente o colega }] \\
\text {... }\end{array}$ & \\
\hline
\end{tabular}


632. P: E ...?

633. Arlindo: Colocamos cobre. E ficaria verde.

634. P: Sulfato de cobre? E com o tiocianato?

635. Luciana: Ficaria verde. E não ficou.

636. P: Continuou azul do próprio cobre. E ai?

637. Arlindo: Fomos para o brometo.

638. Luciana: Não, nós fizemos primeiro o cloreto.

638. P: Com cloreto então? Bem, cloreto com prata ...?

640. Luciana e Arlindo: Dá um precipitado branco.

641. P: Bem, então, a sua amostra já é branca, então vamos eliminar os outros. Qual pode ser além do cloreto?

642. Luciana e Ângela: O sulfato ou tiossulfatos.

643. P: Então como é que você eliminaria o sulfato?

644. Luciana: O sulfato formou um precipitado branco.

645. Ângela: Isto, um precipitado branco.

646. P: O sulfato com a prata fica branco. Mas como é que você eliminaria o sulfato?

647. Arlindo: A gente teve que fazer outro teste. Pegamos aqui outro teste ... cadê? ...

648. Luciana: Eu não lembro...

649. Se vocês pegarem a sua amostra... olha, o sulfato reage com bário... o reagente de grupo para o sulfato é o bário. Pega a amostra...

Os alunos começam a preparar o teste que o professor está narrando, colocam no tubo de ensaio.

650. P: Pega a amostra e adiciona bário.

00:33:10 651. Arlindo: Não ocorreu nada.

652. P: Então é sulfato?

653. Arlindo: Não.

654. P: Então pronto, já está eliminado o sulfato. O que mais que sobrou?

655. Arlindo: Sobrou o tiossulfato, que também reage com bário.

656. Luciana e Arlindo: Então também não é.

657. P: Então qual foi o único que sobrou?

658. Luciana: O cloreto!

659. P: Então a sua amostra é um ...?

660. Arlindo e Luciana: Cloreto!

661. P: De quê?

662. Luciana: De cálcio.

663. P: Ok! Muito bem!

664. Arlindo: Mas se a gente quiser constatar por mais um

00:34:08 teste que é cloreto, tem como fazer outro teste, não tem?

665. P: Sim, você precisa procurar um teste específico para

folhear o cloreto.

Vogel 
para cloreto.

00:34:23 contrário?

... [começam a rir $]$...

668. P: Como assim fazer ao contrário?

669. Ângela: Deixa eu pensar...

670. Luciana: A gente pegou um cloreto e fez com que ele reagisse com o nitrato de prata. Depois a gente reagiu ele com..

671. Ângela: Uma outra coisa.

672. Luciana: Que deu isso! Um formou um precipitado branco e o outro não. Mas ai você falou assim pra gente: mas cadê a amostra? A gente não pegou a amostra, a gente pegou um cloreto qualquer.

673. P: Entendi.

674. Ângela: A gente pegou cloreto de cálcio e nitrato de prata.

675. Luciana: Ai coincidiu do cloreto ser de cálcio.

676. Ângela: E estava certo.

O Arlindo continuou a procurar um teste específico para cloreto e o realizou.

677. P: Que teste é este?

00:35:14 678. Arlindo: Com nitrato de chumbo. Mas não formou precipitado nenhum.

679. Luciana: Depende da concentração, não é?

680. Arlindo: Depende da concentração?

681. P: Você quer precipitar o ... ?

682. Arlindo: O cloreto... mas formou bem pouquinho.

683. P: Ah, então esta formação... o pouco ou o muito depende do quê?

684. Arlindo e Luciana: Da concentração.

685. P: E mais do quê?

... [silêncio $].$.

686. P: O chumbo, qual é a característica do chumbo?

$00: 35: 45$

... [silêncio $].$.

687. P: Ele é um metal ...?

688. Luciana: Ele precipita rápido.

689. P: Mas isto depende do quê? ... Do ... ? .... pH ...

690. Luciana, Ângela e Arlindo: Ahhhhh Luciana

691. P: Porque ele é um anfótero. Então em função do $\mathrm{pH}$ você escreve esta pode ter mais precipitado ou menos precipitado, ok? 
Episódio 25: Argumentação evidenciando a atenção na leitura do rótulo para escolha do reagente

\begin{tabular}{lll}
\hline Tempo & Transcrição da fala & $\begin{array}{l}\text { Comentários } \\
\text { contextuais }\end{array}$ \\
\hline 00:36:18 & $\begin{array}{l}\text { 692. P: Então vamos retomar. Vocês suspeitavam que era lítio } \\
\text { porque vocês adicionaram carbonato e houve uma } \\
\text { precipitação. }\end{array}$ & $\begin{array}{l}\text { Os alunos } \\
\text { realizaram } \\
\text { um teste via }\end{array}$ \\
& 693. Wendel: Sim, houve uma precipitação. & úmida para \\
& 695. Ai vocês acabaram de fazer um teste que foi qual? & confirmação \\
696. P: Não, não, não, não... & de lítio, mas \\
& 697. Renato: Hummm... cadê? & trocaram o \\
698. P: O que é este frasco ai? & frasco do \\
& 699. Renato: Hummm... [começa $a$ rir] .... é sulfato de sódio... \\
& mas era pra ser fosfato de sódio... \\
700. P: Vocês trocaram o frasco, pegaram o reagente errado. & \\
\hline
\end{tabular}

Episódio 26: Argumentação sobre a marcha analítica realizada para o cátion

\begin{tabular}{|c|c|c|}
\hline Tempo & Transcrição da fala & $\begin{array}{l}\text { Comentários } \\
\text { contextuais }\end{array}$ \\
\hline 00:37:02 & $\begin{array}{l}\text { 701. Renato: O lítio é um metal alcalino, então ele cai para } \\
\text { aquela idéia aqui da coloração. O lítio é alcalino? Olha ai na } \\
\text { tabela. } \\
\text { 702. Wendel: É alcalino. } \\
\text { 703. Renato: O cálcio? } \\
\text { 704. Claudinei: É alcalino terroso. } \\
\text { 705. Renato: Então o que acontece aqui... ai a coloração que a } \\
\text { gente observou foi o que: um laranja... nós cremos que era um } \\
\text { vermelho... mas então, o cálcio ele apresenta laranja, verde e } \\
\text { violeta. } \\
\text { 706. Wendel: Não tinha verde. } \\
\text { 707. Renato: Mas o violeta lembra que a gente ficou numa } \\
\text { certa dúvida? Esse violeta... } \\
\text { 708. Wendel: O que tem com verde e violeta? } \\
\text { 709. Renato: Esse verde amarelado... apareceu um pouco sim... } \\
\text { 710. Wendel: Mas não tinha verde. } \\
\text { 711. Renato: Agora, o violeta é quase imperceptível. Foi o que } \\
\text { a gente imaginou mesmo... } \\
\text { 712. Wendel: Ou era laranja e violeta, não tinha verde. } \\
\text { 713. Renato: Mas e se for estrôncio? Por que não foi } \\
\text { estrôncio? } \\
\text { 714. Wendel: Porque ele solubilizou... } \\
\text { 715. Renato: Por causa do reagente de grupo... ele não foi } \\
\text { solubilizado? Então não era estrôncio. } \\
\text { 716. Wendel: Isso. }\end{array}$ & $\begin{array}{l}\text { Os alunos } \\
\text { fazem uma } \\
\text { discussão } \\
\text { buscando } \\
\text { informações } \\
\text { nas } \\
\text { anotações } \\
\text { realizadas } \\
\text { durante o } \\
\text { experimento } \\
\text { e na tabela de } \\
\text { linhas do } \\
\text { espectro do } \\
\text { Vogel }\end{array}$ \\
\hline $00: 38: 11$ & $\begin{array}{l}\text { 717. P: Mas uma coisa vocês fizeram e não estão se atentando } \\
\text { a ela. Vocês pegaram a amostra e adicionaram na amostra }\end{array}$ & \\
\hline
\end{tabular}


carbonato. E o que aconteceu?

718. Renato: Teve um precipitado branco...

Começa a procurar o tubo de ensaio contendo esta reação em específico.

718. P: Então a sua amostra é reativa com o carbonato.

719. Renato: Certo... então aqui... [começa a olhar para o Vogel]...

720. P: Quais são os cátions que reagem com o carbonato?

... [silêncio $].$.

Wendel busca no Vogel e começa a descrevê-los.

721. Wendel: Cálcio, estrôncio, bário e magnésio.

722. P: Então faça uma lista dos que reagem com o carbonato.

... [silêncio $]$...

723. P: Repete de novo esta lista. Repete novamente o que

Buscam você acabou de dizer.

papel e

caneta 725. P: Cálcio...

726. Wendel: E possivelmente ferro em solução aquosa.

727. P: Então é... faz um teste individualmente para cada um.

728. Wendel: Mas a gente fez um teste para ferro e estávamos procurando um precipitado e não formou...

729. P: Mas se a sua amostra fosse de ferro qual seria a cor da amostra?

730. Renato: É, nós já descartamos.

731. P: Não, cadê o frasquinho com a amostra?

732. Renato: A amostra mãe?

733. P: Com a amostra sólida! Cadê o frasquinho com a amostra sólida?

734. Renato: Aqui.

735. P: Qual é a cor da amostra?

736. Wendel e Renato: Branco.

737. P: Se fosse ferro, qual seria a cor dela?

738. Renato: Amarelado.

Pega o frasco

739. P: Então é ferro?

com a

740. Renato e Wendel: Não!

amostra

741. P: Então quais são os outros?

742. Wendel: Cálcio, estrôncio e bário.

743. P: Todos estes são brancos.

744. Wendel: A gente está tentando então estrôncio...

745. P: Cálcio, estrôncio e ...

00:40:08 746. Wendel: Bário e magnésio.

747. P: Se for bário... o bário precipita com quem? Olha na tabelinha ai... 
748. Renato: Precipita com sulfato.

749. P: Vocês já fizeram este teste e precipitou?

Pegam a

Renato começa a procurar nas anotações.

tabela de

solubilidade

750. P: Vocês já adicionaram sulfato.

Não encontram e ficam na dúvida.

751. P: Pega a sua amostra e adiciona bário.

752. P: Se for bário, na presença de sulfato tem que dar um

00:40:53 precipitado branco.

Claudinei

prepara a

Adicionam o reagente e nada aconteceu.

amostra

753. P: Então é bário?

754. Renato e Wendel: Não!

755. P: Então vocês já eliminaram o bário. O que sobrou?

756. Wendel: Cálcio e magnésio.

757. P: Cálcio e magnésio.

758. Wendel: Quando a gente fez o de estrôncio... no de

estrôncio também não tinha dado nada.

Wendel busca a confirmação nas anotações.

759. Wendel: Formou um precipitado?

760. Renato: Não!

Episódio 27: Argumentação a respeito das conclusões da pesquisa para determinação do cátion e ânion que formam a amostra

\begin{tabular}{|c|c|c|}
\hline Tempo & Transcrição da fala & $\begin{array}{l}\text { Comentários } \\
\text { contextuais }\end{array}$ \\
\hline $00: 42: 38$ & $\begin{array}{l}\text { 761. P: Então como é que vocês finalizaram a pesquisa do } \\
\text { cátion e do ânion? O que vocês descobriram? ... Não última } \\
\text { parte vocês estavam na dúvida de qual era o cátion, vocês } \\
\text { listaram quais possibilidades? } \\
\text { 762. Renato: Nós listamos lítio, magnésio, cálcio, estrôncio e } \\
\text { bário. } \\
\text { 763. Wendel: Então a gente eliminou o bário porque ele foi } \\
\text { solúvel com carbonato... } \\
\text { 764. Renato: Com carbonato? } \\
\text { 765. Wendel: Com sulfato! } \\
\text { 766. P: Mas espera ai. Por que vocês chegaram nestes cátions? } \\
\text { 767. Renato: Devido a coloração e alguns testes que fizemos... } \\
\text { no caso, reagimos com nitrato, com cloreto... no caso até } \\
\text { confirmamos que ele é um cloreto e os iodetos. } \\
\text { 768. P: Onde entra esta informação que a amostra mais a } \\
\text { adição de carbonato? }\end{array}$ & $\begin{array}{l}\text { O P refere-se } \\
\text { ao episódio } \\
25\end{array}$ \\
\hline
\end{tabular}


769. Renato: Foi o primeiro teste. Nós esperávamos dar um precipitado de carbonato de lítio e foi o que não ocorreu, ela ficou solúvel. Então já era uma hipótese de não ser o lítio. 770. Wendel: Carbonato e lítio.

771. P: Ok!

772. Renato: Então, após isto...

773. P: O carbonato faria quais cátions precipitarem?

774. Renato: O carbonato... hummm... seria os alcalinos... alcalinos e de amônio. Com exceção do lítio.

775. P: Não! Releia de novo esta tabela.

776. Renato: Carbonatos, a regra, são insolúveis, os solúveis seriam os alcalinos e de amônio.

777. P: Ah, entendi... E ai, como é que nasceu aquela tabela ali?

O P fala apontando

Os alunos olham para a tabela apontada pelo professor mas permanecem em silêncio. para a tabela de anotações dos alunos

778. Renato: Foi por que... por causa do precipitado branco...

00:45:03 ... [silêncio $] \ldots$

779. Renato: Aqui o magnésio foi descartado porque não apresenta coloração na chama... como ... [a chama $]$... apresentou cor nós já descartamos o magnésio. O lítio já tinha sido descartado conforme o precipitado ... [com fosfato $]$... O bário, porque apresentou solubilidade ...

780. Wendel: Com sulfato.

781. Renato: E restou qual? O estrôncio e o cálcio. Fazendo esse, o estrôncio confirmou precipitação.

782. Wendel: Precipita.

783. Renato: Então nós descartamos o estrôncio.

784. Renato: Então sobrou o cálcio. E como nós confirmamos que era o cálcio? Ele não apresenta precipitado... este ai mesmo... com a amostra.

Os alunos descrevem a marcha realizada que estão anotadas

785. P: É.... quem fez o estrôncio e o bário precipitar?

786. Renato: O sulfato.

00:47:24 787. P: O sulfato. Então o sulfato faz o estrôncio precipitar, o sulfato faz o bário precipitar mas não faz o cálcio precipitar. E ai você chegou a conclusão que não é a amostra por conta deste teste aqui?

788. Renato: Exatamente por ele... conforme o Vogel... página... aqui...

Começa a ler o descritivo analítico do Vogel.

789. Renato: Solução saturada de sulfato de cálcio, um precipitado branco de sulfato de cálcio... de estrôncio... 00:47:55 790. Wendel: Opa, não é este aqui. 


\section{Começam a folhear o livro.}

791. Renato: Não, aqui é carbonato de amônio... aqui! Solução saturada de sulfato de cálcio, nenhum precipitado é formado, diferenciando de sulfato de estrôncio e o sulfato de bário.

Então a gente confirmou que seria cálcio.

792. P: Pelo ensaio de chama não foi fácil a identificação?

793. Wendel: Não por que...

00:48:34 794. Renato: Teve uma confusão...

795. Wendel: Apresentou uma coloração...

796. Renato: Verde amarelado ficou um pouco confuso. Nós

não conseguimos observar este verde amarelado.

Pega a tabela

797. Wendel: Mostrando que a olho nu, pra quem está

das linhas de

analisando ocorre dúvidas.

espectro do

798. P: Hummmm... Então pra um trabalho deste de pesquisa... Vogel

hummm... vocês chegaram a conclusão que a amostra é?

799. Renato: Sulfato de cálcio... hummm... cálcio...

800. P: Não. O cátion é?

801.Wendel: O cátion é o cálcio.

802. P: E o ânion?

803. Wendel: Cloreto... cloreto de cálcio.

804. P: Cloreto de cálcio.

Episódio 28: Argumentação a respeito da compreensão das etapas realizadas para a marcha analítica e organização dos resultados

\begin{tabular}{|c|c|c|}
\hline Tempo & Transcrição da fala & $\begin{array}{l}\text { Comentários } \\
\text { contextuais }\end{array}$ \\
\hline $00: 50: 17$ & $\begin{array}{l}\text { 805. P: Num trabalho deste, como vocês definem as etapas? O } \\
\text { que vocês fariam em casa etapa? } \\
\text { 806. Wendel: A gente começaria organizando uma lista. A } \\
\text { gente fez uma seqüência que a gente aprendeu em laboratório. } \\
\text { A gente começou com ensaio de chama, ai não foi apresentada } \\
\text { a resposta mais correta, ai partimos para a parte de úmida... ai } \\
\text { fizemos todos os testes... } \\
\text { 807. Renato: Qual seria a sequiência: você observar primeiro } \\
\text { aspectos visuais da amostra, inicial, após isso declarar uma } \\
\text { amostra mãe e ai iniciar a sequiência, ok? Primeiramente seria } \\
\text { este ensaio por via seca, o ensaio de chama, porque ela } \\
\text { possivelmente te trás uma... o cátion. } \\
\text { 808. Wendel: Mesmo assim mostrando que tem dúvidas. } \\
\text { 809. Renato: Sim! } \\
\text { 810. Wendel: Então a pessoa que está analisando... a olho nu... } \\
\text { a chama engana. } \\
\text { 811. Renato: Após isto, o início de uma marcha de... reações... } \\
\text { para comprovação dos dados adquiridos. } \\
\text { 812. P: E como é que você vê que misturando duas coisas, } \\
\text { como é que você observa se reagiu ou não reagiu? O que te }\end{array}$ & \\
\hline
\end{tabular}


\begin{tabular}{ll}
\hline 00:50:48 & mostra isto? \\
& 813. Renato: A coloração, a formação de precipitado... \\
& 814. P: Então estas são características observadas? \\
& 815. Renato: Sim, aspectos visuais principalmente. \\
& 816. P: E depois de observadas, qual é a maior dificuldade? \\
& 817. Wendel: É, no caso aqui, seria encontrar... \\
& 818. Renato: Por eliminação na tabela... você definir qual seria \\
& o reagente de grupo específico pra você poder fazer a \\
& eliminação dos compostos, até declarar um ânion e assim \\
& você... \\
819. Wendel: Porque o importante é sempre ter em mãos os \\
dados pra gente tirar nossas dúvidas. \\
820. P: Então existe sempre uma relação entre as respostas que \\
os grupos, as substâncias vão tendo? \\
821. Wendel e Renato: Sim! \\
822. P: E interpretar estas relações é fácil? Como que é? \\
823. Wendel: A gente requer dados de confiança, juntar todos \\
os dados possíveis para poder alcançar a possível solução. A \\
gente ainda não chegou na solução concreta. Ai, devido a estes \\
dados a gente faz uma eliminação por etapas, por meio da \\
bateria de testes, até chegar na solução que seria cloreto de \\
cálcio.
\end{tabular} 